
Pesquisa Discente no Curso de Administração da PUC-SP - 2018/2019 



\author{
Organização \\ Roberto Sanches Padula \\ Luciane Tudda
}

\title{
Pesquisa Discente no Curso de Administração da PUC-SP - 2018/2019
}




$\begin{aligned} \text { Capa } & \text { Marcus Gisolfi | Tikinet } \\ \text { Projeto gráfico } & \text { Maurício Marcelo | Tikinet } \\ \text { Diagramação } & \text { Raquel Prado | Tikinet } \\ \text { Imagens de capa } & \text { Roberto Padula e Thais Polato } \\ \text { Revisão } & \text { Giovana Meneguim e Luiza Gomyde | Tikinet }\end{aligned}$

Dados Internacionais de Catalogação na Publicação - CIP

T899

Padula, Roberto Sanches, Org.; Tudda, Luciane, Org.

Pesquisa discente no Curso de Administração da PUC-SP - 2018/2019 /

Organização de Roberto Sanches Padula e Luciane Tudda . - São Paulo:

Tiki Books: PUC-SP/PIPEq, 2020.

371 p.; II.

ISBN 978-65-87080-03-1

1. Educação. 2. Ensino Superior. 3. Ensino e Aprendizagem. 4. Metodologia de Ensino. 5. Administração. 6. Docentes. 7. Discentes. 8. Pesquisa. 9. Construção Coletiva. 10. Produção Acadêmica. I. Título. II. PUC-SP. III. Curso de Administração. IV. Tudda, Luciane, Organizadora. V. Padula, Roberto Sanches, Organizador.

CDU 378

CDD 378

Catalogação elaborada por Regina Simão Paulino - CRB 6/1154

\section{TIKI \\ books}

Rua Santanésia, 528, $1^{\circ}$ andar - Vila Pirajussara

CEP: 05580-050 - São Paulo - SP

Tel.: (11) 2361-1808/1809

www.tikinet.com.br 


\section{Sumário}

Apresentação

Prof. Dr. Roberto Sanches Padula e Profa. Dra. Luciane Tudda

Precarização do trabalho: informalidade, terceirização e os impactos na vida do trabalhador

Jâmile Maria Simão Silva e Myrt Thânia de Souza Cruz

Gestão da diversidade racial nas empresas como combate ao racismo institucional 33

Stella Martins Uchoa e Myrt Thânia de Souza Cruz

O processo de inserção de jovens transexuais e transgêneros no mercado de trabalho: um estudo com estudantes de uma universidade confessional paulistana. 49

Paloma Mota da Silva e Dione Fagundes Nunes Gomes

Desigualdade de gênero nas agências bancárias: percepção de mulheres durante seu processo de construção de carreira 73 Caio Cesar Gonçalves Pires e Crisomar Lobo de Souza

Inclusão de pessoas com deficiência na indústria farmacêutica:

o caso da Roche .105

Mariáh de Lima e Luciane Tudda

Tecnologia móvel digital para pessoas idosas .127 Luan Alves Monteiro, Fernanda Contarelli Lima e Roberto Sanches Padula 
Responsabilidade social em uma empresa de cosmético

Mariana Soares de Araujo e José lesca Rodrigues

Reflexões sobre o conceito de ergonomia e a percepção de retorno para as organizações e funcionários. 189

Júlio César Isaguirre e Renata Schirrmeister

Qualidade de vida e gestão de carreira para estudantes de uma instituição de ensino superior de São Paulo - uma análise sobre as condições para o crescimento profissional

Breno Barbosa Lisboa e Dione Fagundes Nunes Gomes

O papel da simplicidade no trabalho

Valéria Bullo Robalinho e Elisabete Adami Pereira dos Santos

Empresa Júnior: o ex-Júnior e o mercado de trabalho .269

Matheus Boyamian Mekhitarian e Elisabete Adami Pereira dos Santos

Hábitos alimentares e nível de atividade física associados a qualidade de vida de estudantes da Faculdade de Economia e Administração da Pontifícia Católica de São Paulo 299

Daniela Meanda e Mauro Maia Laruccia

Gestão de marcas de luxo na era digital: redes sociais 325

Cassia Almeida de Barros e Agustin Perez Rodrigues

Aplicabilidade da Metodologia CAMEL para avaliar o risco de crédito de instituições financeiras de grande porte listadas na B3 (Brasil, Bolsa e Balcão): estudo de caso do Banco Itaú Unibanco 347

Beatriz Tavares Barca da Silva e José Odálio dos Santos 


\section{Apresentação}

Prof. Dr. Roberto Sanches Padula e Profa. Dra. Luciane Tudda

O objetivo do curso de graduação em Administração da Pontifícia Universidade Católica de São Paulo é dar uma visão abrangente dessa área, proporcionando aos alunos visão crítica e humanista em seus projetos acadêmicos e profissionais de forma que possam atuar em diversos campos organizacionais e neles fazer a diferença. Teorias da administração e das organizações, sociologia, contabilidade, matemática, psicologia, estatística, direito, finanças, marketing, operações, pessoas, estratégias, economia, tecnologia da informação, ética, sustentabilidade, inovação, entre outras, são disciplinas do curso com a intenção de dar aos alunos o repertório necessário para trabalhar em organizações de qualquer setor econômico.

Entre os trabalhos que os alunos podem desenvolver ao longo do curso, se destacam os de Iniciação Científica - IC e o de Conclusão de Curso - TCC. O primeiro é elaborado normalmente no segundo ano do curso, e o outro, no final. Para ambos é utilizada a metodologia científica, que traz a necessidade de disciplina, seleção de bibliografia, rigor na abordagem do assunto e obediência a normas de apresentação, incluindo, normalmente, uma pesquisa para geração de dados primários. A aplicação do método traz ao aluno uma forma de pensamento crítico sistematizado em busca das respostas ou soluções de problemas por eles elencados no mundo das organizações. 
O objetivo desta coletânea é divulgar as melhores produções acadêmicas dos discentes do curso de graduação de Administração, contendo as pesquisas produzidas no período de 2018 a 2019. Os trabalhos apresentam problemas de pesquisas dos assuntos mais importantes, urgentes e atuais tratados pela área de administração. Os docentes orientadores tiveram a função de ajudar a adaptar os trabalhos finais apresentados para o formato de artigos, os quais poderão ser apresentados em congressos ou submetidos para divulgação em periódicos.

Buarque (1994) destaca que a universidade tem um papel permanente: gerar saber de nível superior para viabilizar o funcionamento da sociedade. Esta coletânea pretende contribuir para o alcance desse objetivo.

O livro começa com diversos artigos que tratam a precarização do trabalho, a diversidade de gênero e a inclusão de pessoas com deficiência e de idosos. Na sequência, são abordados temas como responsabilidade social, qualidade de vida e carreira. Gestão de marcas de luxo e metodologia de avaliação de risco de créditos fecham a coletânea.

O artigo Precarização do trabalho: informalidade, terceirização e os impactos na vida do trabalhador, de Jâmile, desenvolvido para o programa de iniciação científica, faz análise crítica sobre a situação dos trabalhadores brasileiros de baixa renda no século XXI, a fim de compreender a sua percepção sobre o mundo do trabalho, sobretudo os impactos do trabalho precarizado e informal e seus desdobramentos para a vida do trabalhador de baixa renda. Fenômenos interseccionais como racismo, gênero e faixa etária indicam que os marcadores sociais são fundamentais para se entender chaves de análise que possibilitam a aplicação de políticas de enfrentamento à situação colocada.

Stella, também do programa de iniciação científica, desenvolveu o artigo Gestão da diversidade racial nas empresas como combate ao racismo institucional, que objetiva visibilizar as razões da ausência da população negra no universo empresarial, sobretudo na ocupação das vagas corporativas, e as necessidades de que essa população seja inserida, bem como propor estratégias para que as organizações realizem esse trabalho de modo efetivo. Discute os riscos de se ver ondas passageiras para a gestão da diversidade racial nas empresas como chamariz para modismos de consumo, chamando a atenção para a necessidade de mudanças estruturais, na sociedade brasileira como um todo, que 
possam desconstruir o racismo como relação de colonização no trabaIho nos dias atuais.

Paloma discute em seu TCC os desafios que os jovens enfrentam quando do ingresso no mercado de trabalho em $\mathbf{O}$ processo de inserção de jovens transexuais e transgêneros no mercado de trabalho - um estudo com estudantes de uma universidade confessional paulistana. Ela coloca que a situação se agrava quando se trata de jovens transexuais e transgêneros que precisam lidar com o preconceito que insiste em obscurecer suas competências. $\mathrm{O}$ artigo põe luz nessa realidade e propõe uma reflexão honesta a partir dos depoimentos desses jovens.

O TCC de César diz que, aparentemente, se pode achar que a desigualdade de gêneros esteja desaparecendo e que as mulheres têm os mesmo direitos que os homens, visto as grandes conquistas obtidas pelas mulheres nas últimas décadas, mas a realidade é que as relações de desigualdade estão sendo naturalizadas por meio de reafirmações que colocam esse comportamento como comum em várias sociedades. O capítulo Desigualdade de gênero em agências bancárias: percepção de mulheres durante seu processo de construção de carreira tem como objetivo ampliar a discussão para o setor bancário, visto a importância do trabalho e da procura pela igualdade entre os gêneros na a sociedade e para as mulheres.

Mariah discute no artigo A Inclusão de Pessoas com Deficiência na Indústria Farmacêutica: O Caso da Roche, do seu TCC, as ações que a empresa vem adotando para essa inclusão. O trabalho teve como objetivo principal refletir sobre essa prática, na perspectiva da empresa e de seus colaboradores com deficiência, contribuindo para o aprimoramento dessa política, bem como para que demais empresas formulem ações para questões relacionadas aos problemas de inclusão social, com foco em Pessoas com Deficiência.

A inclusão digital dos idosos é discutida por Luan e Fernanda, em pesquisa para o programa de iniciação científica. No artigo Tecnologia Móvel Digital para Pessoas Idosas, é discutido o crescimento demográfico de idosos e como estes interagem com os smartphones e seus aplicativos, hoje essenciais para a convivência social. Os dados levantados demonstram que o uso dos aparelhos celulares pelos idosos se dá em aplicações mais simples, como ligações, ouvir músicas, mandar 
mensagens, entre outras, e que esse público apresenta algumas dificuldades para manusear os aparelhos, principalmente relacionadas à baixa usabilidade e às configurações.

Para entender como se coloca a responsabilidade social em prática, Mariana, em seu TCC, escolheu uma empresa de cosméticos. O artigo Responsabilidade social em uma empresa de cosmético diz que uma organização deve ter conduta ética e transparente, implementando ações que beneficiam a sociedade como um todo. A Natura S.A. foi a escolhida, pois é reconhecida pelo seu compromisso com a sustentabilidade, sendo apontada por diversas vezes como destaque, por sua atuação social, pelo Instituto Ethos de Empresas e Responsabilidade Social.

No seu trabalho de iniciação científica, Júlio Cesar fez, no artigo Reflexões sobre o conceito de ergonomia e a percepção de retorno para as organizações e funcionários, uma pesquisa em profundidade abrangendo as várias dimensões da ergonomia em uma grande empresa fabricante de cosméticos, desvelando o humanismo como forma de gestão viável e lucrativa para as organizações.

A busca pelo desenvolvimento da carreira profissional é anseio legítimo de qualquer jovem, entretanto, esse processo pode exigir um custo. O artigo do TCC de Breno, Qualidade de Vida e Gestão de Carreira para Estudantes de uma Instituição de Ensino Superior de São Paulo - uma análise sobre as Condições para o Crescimento Profissional, trata da disposição de jovens profissionais quando esse custo envolve qualidade de vida. Uma reflexão que vale para qualquer profissional, em qualquer tempo.

O trabalho de TCC de Valéria, O papel da simplicidade no trabalho, teve como objetivo principal discutir o papel da simplicidade no ambiente profissional com foco na comunicação (escrita, oral e visual). A pesquisa de campo foi aplicada a uma amostra de 40 pessoas, entre estudantes e gestores de um grande banco na cidade de São Paulo, e os dados coletados mostraram que, de fato, a simplicidade tem grande importância no ambiente de trabalho hoje, podendo ser praticada de forma organizada, inteligente, com atitudes simples e metodologias ágeis, podendo ser muito útil na gestão de times, na prevenção de impactos negativos trazidos pelo mundo VUCA e no melhor alcance dos objetivos.

O texto Empresa Júnior: o ex-júnior e o mercado de trabalho, produto do TCC de Matheus, mostra o resultado de suas pesquisas e discute a 
contribuição que o desenvolvimento das soft skills traz para os estudantes que atuaram em empresas juniores durante seus cursos de graduação. Os resultados da pesquisa de campo demonstraram que a atuação nas empresas juniores prepara melhor o estudante para o ingresso no mercado de trabalho e contribui sobremaneira para seu crescimento nele.

O artigo resultante do TCC de Daniela, Hábitos alimentares e nível de atividade física associados à qualidade de vida de estudantes da Faculdade de Economia e Administração da Pontifícia Universidade Católica de São Paulo, teve por objetivo identificar como o Índice de Massa Corporal, os hábitos alimentares e o nível de atividade física impactam na produtividade acadêmica e na qualidade de vida de alunos da mencionada faculdade. Foi realizado estudo transversal constituído por 75 estudantes do curso de administração, com coleta de dados por meio de um questionário constituído de perguntas para se obter dados para o cálculo do Índice de Massa Corporal e traçar perfis com a utilização da estatística descritiva. Concluiu-se que a Universidade tem papel importante na qualidade de vida dos alunos e que os alunos deveriam ser incentivados a disponibilizar tempo para a prática de atividades físicas.

O trabalho de iniciação científica de Cassia, Gestão de marcas de luxo na era digital: redes sociais, traz uma pesquisa que destaca a influência das redes sociais na gestão de marcas de luxo e em seus consumidores, com intuito de compreender as estratégias tomadas pelas marcas para driblar os desafios das mídias sociais, com base no comportamento do consumidor.

Aplicabilidade da Metodologia CAMEL para avaliar o risco de crédito de instituições financeiras de grande porte listadas na B3 (Brasil, Bolsa e Balcão): Estudo de caso do Banco Itaú-Unibanco, a iniciação científica de Beatriz, traz um tema atual e relevante, uma vez que destaca os principais riscos do setor bancário e a aplicabilidade da Metodologia CAMEL para mensurar a exposição à insolvência de instituições financeiras. Para validar os resultados da metodologia proposta, foi selecionado o maior banco privado nacional listado na bolsa de valores: o Itaú-Unibanco.

Esta coletânea foi desenvolvida com recursos do Plano de Incentivo a Pesquisa (PIPEq) - Publicação de Livros-Coletâneas (PUBLIVRO -PUC/ SP) - 2020, da Pontifícia Universidade Católica de São Paulo (PUC-SP). 



\title{
Precarização do trabalho: informalidade, terceirização e os impactos na vida do trabalhador
}

\author{
Jâmile Maria Simão Silva \\ Myrt Thânia de Souza Cruz
}

\begin{abstract}
Resumo
O capítulo se constitui de uma análise crítica sobre a situação dos trabalhadores brasileiros de baixa renda no século XXI, a fim de compreender a sua percepção sobre o mundo do trabalho, sobretudo os impactos do trabalho precarizado e informal e seus desdobramentos para a vida do trabalhador de baixa renda. Resulta de pesquisa de Iniciação Científica feita sobre trabalhadores de baixa renda da região de São José dos Campos, utilizando questionários com perguntas fechadas e abertas com foco em compreender de que forma o trabalho precarizado e informal impactava no cotidiano dos trabalhadores, na sua saúde, alimentação e qualidade de vida em geral. Foi constituída por importante revisão bibliográfica de autores consagrados que estudam o mundo do trabalho. Os principais resultados apontam para o agravamento da situação socioeconômica dos trabalhadores informais, com perda significativa de renda, bem como diminuição dos acessos à educação, saúde, segurança e alimentação. Fenômenos interseccionais como racismo, gênero e faixa etária indicam que os marcadores sociais são fundamentais para se entender chaves de análises que possibilitem a aplicação de políticas de enfrentamento à situação colocada. Assim, espera-se contribuir para reflexões críticas acerca da situação do trabalhador informal e, sobretudo, como espaço de denúncia das mazelas às quais estão submetidos.
\end{abstract}

Palavras-chave: Trabalho precarizado. Trabalhador de baixa renda. Preconceitos. Capitalismo. 


\section{Introdução}

O Brasil é um país com nítidas desigualdades sociais e econômicas, onde a população vive uma realidade em que a equidade de oportunidades é problemática. Para alguns, isso se dá graças ao sistema capitalista, que poda a capacidade dos indivíduos de ascender ao bem-estar ideal, à medida que a oferta de possibilidades cria um desequilíbrio entre os cidadãos. Por ter como força motriz a acumulação do capital e lucratividade dos esforços produtivos, o sistema necessita de duas classes de pessoas para existir: as que detenham os meios de produção e as que vendem sua mão de obra como o único meio de subsistência. Graças à interdependência das partes necessárias para a consolidação do capitalismo, todas as esferas da vida humana foram moldadas, afetando, principalmente, o trabaIho, fator primordial para a existência e permanência desse sistema. Ao basear-se na mais-valia, a desigualdade se constitui como um reflexo do ato de usufruir dos esforços de uma classe que detenha a força de trabalho, mas não os meios de produção.

No capitalismo global (ARRUDA, 2013), a velocidade de transformação se intensificou, assim como a desregulamentação e flexibilização no meio do trabalho (ANTUNES, 2014). Mudanças expressivas, como a mecanização da produção e a consequente diminuição da necessidade de capital humano, aumentam em ritmo acelerado desde a primeira Revolução Industrial, evidenciadas pela "internetificação" do século XXI e a dependência tecnológica. Essas modificações podem acarretar desigualdade na sociedade à medida que contribuem para a exclusão dos membros em situações mais fragilizadas do ponto de vista socioeconômico.

Isso se dá porque ao diminuir a necessidade de trabalho demandada pelos meios de produção, restringe-se o leque de possibilidades para os que procuram empregos que exijam menos qualificação profissional e acadêmica. Assim como permite-se uma exploração diferenciada da mão de obra, com postos de trabalho com horários, benefícios e remunerações flexíveis, o que pode ser ilustrado pela Lei 13.467 (BRASIL, 2017), que redefiniu pautas como férias, jornada de trabalho, remuneração etc., e com a normalização da informalidade. 
A partir da análise desse contexto, cresceram as preocupações de cunho ético e moral dentro da compreensão da realidade do trabalho no Brasil, bem como a percepção desse trabalhador que vive as dificuldades do cotidiano brasileiro. Para obter uma análise empírica dos dados coletados pela pesquisa bibliográfica, foi realizada uma pesquisa de campo que contou com a participação anônima de 73 pessoas.

\section{O trabalhador brasileiro}

Em um país de grandeza continental e com raízes na exploração, a situação encontrada pelos brasileiros é única. Há diferenças regionais em questões culturais, econômicas e geográficas, problemas na distribuição de renda e uma pobreza (definida pela renda mensal per capita inferior a 145 reais) que atinge cerca de 13,5 milhões de brasileiros (IBGE, 2019), o maior nível em sete anos. Quando analisada a totalidade dos trabalhadores, a renda mensal no Brasil é de 2.490 reais (IBGE, 2020b), porém a contagem dos dados se dá por meio de uma média simples, dada pela "razão entre o total dos rendimentos domiciliares (em termos nominais) e o total dos moradores" (IBGE, 2019 , p. 2), possuindo coeficientes de variação que superam $10 \% \mathrm{em}$ algumas regiões do país (IBGE, 2018).

Como reflexo e razão das dificuldades mencionadas, está o índice de desemprego e a subutilização da mão de obra no país, que compreendem $12,9 \%$ e $27,5 \%$ da população, respectivamente (IBGE, 2020). Esses números tiveram crescimento durante a pandemia de Covid-19, porém são crônicos no país e se intensificam desde 2014, quando o Brasil fechou o ano com uma taxa de desemprego de 4,8\% (IBGE, 2015). É interessante ressaltar que nessa população considerada ocupada são computados também os trabalhadores informais.

Um grande impedimento para a capacidade de trabalhar no país é o acesso à educação. A democratização da educação é um fator importante para a construção de uma economia mais inclusiva, uma vez que um menor nível de escolaridade tende a ser associado a menor renda e maior desigualdade social. É estimado que 52\% dos adultos de 25 a 64 anos não possuem o diploma de conclusão do ensino 
médio (OECD, 2018), porém os números são distintos em diferentes localidades do país: no Distrito Federal, uma das com maior rendimento mensal (IBGE, 2019), o número de jovens ingressantes no ensino superior chega a 33\% (OECD, 2018), maior índice do país.

Ao analisar dados de desemprego e subutilização, entende-se a grande competição dentro do mercado de trabalho brasileiro, bem como o crescimento de formas mais precarizadas de trabalho, como a informalidade e os trabalhadores com múltiplas jornadas.

\section{Os impactos da terceirização: presente e futuro}

Com a terceirização, foi criado um tipo de trabalho que trouxe consequências mercadológicas distintas das causadas pelas relações que previamente existiam. Entre elas, destaca-se o impacto que a terceirização pode causar na remuneração salarial do trabalhador.

Esse efeito costuma variar com a probabilidade de terceirização em cada ambiente laboral, afetando principalmente os profissionais de setores nos quais a incidência é maior. Assim, Campos (2016, p. 166) propõe uma análise focada na "remuneração direta e monetária dos assalariados, padronizada pela sua carga horária de trabalho ordinária e, também, extraordinária" como um indicador de qualidade para as relações de trabalho:

Como resumo desses resultados, [...] constatam-se diferenças entre a situação dos assalariados que: i) têm vínculo direto; ii) têm média probabilidade de serem terceirizados; e iii) têm alta probabilidade de serem terceirizados. No que se refere àqueles com média probabilidade, o fato de serem ou não terceirizados afeta relativamente pouco, e em sentidos distintos, a remuneração [...]. Outras variáveis - como a localização dos estabelecimentos ou o sexo, a instrução e o tempo de vínculo dos assalariados - afetam bem mais a remuneração. No que concerne àqueles com alta probabilidade, o fato de serem ou não terceirizados afeta bem mais, e quase sempre no mesmo 
sentido, a remuneração na maior parte das quinze ocupações analisadas. (CAMPOS, 2016, p. 169-170)

Além dos impactos na remuneração, há ainda as preocupações legais baseadas na transferência de responsabilidade entre empresas. Como empresas maiores comumente terceirizam parte de seus serviços por meio de empresas menores, a estrutura empresarial diminui. Esse fato já apresenta uma barreira aos direitos dos trabalhadores, pois os direitos dados ao trabalhador "tendem a ser mais extensos e mais fortes em empresas grandes e/ou bem estruturadas (CAMPOS, 2016)". Há também a descentralização dos trabalhadores dada pela divisão do trabalho nesse modelo, o que dificulta a comunicação entre eles em seu meio profissional e, como consequência, a estruturação de mobilizações e sindicatos. Com o enfraquecimento e desunião nas relações, a retração de direitos pode ser mais facilmente adotada.

Quando se leva em conta a natureza fisicamente extenuante de algumas profissões comumente terceirizadas, como serventes de obras e trabalhadores de limpeza, é possível responsabilizar a quantidade de horas semanais trabalhadas pela grande rotatividade, como uma consequência do cansaço e da possível incapacidade de atender às exigências das empresas contratante ou contratada.

Esse fenômeno não afeta somente a classe trabalhadora e pode causar malefícios dentro de toda a cadeia laboral, afetando também o Estado:

A elevada rotatividade da mão de obra é um dos indicadores mais preocupantes do mercado de trabalho. Para os empregadores, representa um custo de seleção e treinamento que acaba sendo repassado ao preço final, atingindo todos os consumidores. Para os trabalhadores, representa a incerteza de encontrar um novo emprego num curto espaço de tempo e o risco de ter que aceitar menores salários e benefícios, além de ter impactos no cálculo da aposentadoria. Para o Estado, as despesas com seguro-desemprego tendem a aumentar com a alta rotatividade, ocasionando descapitalização do FGTS. (DIEESE, 2017, p. 6) 
Com a tendência de flexibilização, desregulamentação, terceirização, informalidade e intensificação da exploração (ANTUNES, 2014), caminhar para uma regulamentação irrestrita do trabalho terceirizado, permitindo até mesmo a quarteirização, pode aprofundar as desigualdades no país, tendo como consequência uma maior precarização das condições de trabalho (DIEESE, 2017).

\section{O trabalho informal e seu impacto nas esferas sociais}

A informalidade é um tipo de trabalho comum e característico de economias emergentes e que se exacerba em períodos com taxas elevadas de desemprego, em especial para aqueles em situações mais fragilizadas, como discriminação, falta de escolaridade etc. Porém, pode ser considerada uma estratégia atrelada à tendência da flexibilização para compatibilizar as necessidades de produção e diminuir os custos sociais que um trabalhador formal acarreta (por conta da necessidade da tributação do trabalho e o pagamento de benefícios trabalhistas).

O trabalho informal é caracterizado como aquele que não possui vínculo empregatício com uma instituição e é feito por conta própria, como vendedores ambulantes, pessoas empregadas em empresas ilegais ou autônomos que exercem suas atividades sem CNPJ. Para Soares (2008, p. 57), ele é como um produto da relação de capital, sendo parte integrante do sistema e funcional a ele.

Apesar de compor grande parte da força de trabalho brasileira, a informalidade pode ser desvantajosa para o trabalhador e para o Estado. Do ponto de vista estatal, esse profissional não gera tributos sobre a sua produção laboral, e, para o indivíduo que exerce esse tipo de atividade, há o desamparo frente aos benefícios trabalhistas, como vale-transporte ou alimentação, e aos direitos previstos na Consolidação das Leis do Trabalho (CLT). Atualmente, com as mudanças de tendência neoliberal nas leis que regulamentam o trabalho em solo brasileiro, a informalidade pode se tornar ainda mais comum.

Desconsiderando os prejuízos para o Estado, a terceirização pode ser uma opção de subsistência em um país que enfrenta um período de desemprego e mudanças como o Brasil. Além disso, o trabalho 
de muitos não é o suficiente para suprir as necessidades básicas e a renda informal torna-se um instrumento de complemento para atingir melhores condições de vida.

Porém, quando alia-se a exploração do trabalho à falta de direitos do trabalhador em uma economia em que empresas buscam flexibilização e diminuição dos custos de produção, uma situação problemática é criada. O trabalho informal, como componente da renda daqueles que já possuem um trabalho formal e fixo, pode causar grande desgaste por conta da jornada de trabalho estendida. Uma das entrevistadas neste estudo conciliava seu estágio com dois trabalhos informais e sua graduação em Letras:

Trabalho de segunda e sexta em um estágio de seis horas numa escola aqui em São José (dos Campos), aí de final de semana eu faço freelance pra eles nuns simulados de ENEM que eles fazem. Quando não tem trabalho no final de semana ou é feriado, trabalho com uma conhecida minha na casa dela, fazendo aqueles lacinhos de cachorro, sabe? Ela vende pra pet shop. É difícil conciliar com a faculdade, fiquei de exame em duas matérias esse semestre e mudei pro EaD (educação à distância) pra ficar mais fácil, mas preciso pra pagar minhas contas, né? Só o dinheiro do estágio não dá.

\section{O trabalhador multifuncional}

Por analisar a nova organização do trabalho no capitalismo do século XXI, com as tendências de precarização e de superexploração do trabalho (SILVA; FERREIRA; ALMEIDA, 2017) e as diferentes naturezas de trabalho que predominam no cenário brasileiro, é cabível a discussão sobre um novo grupo de trabalhadores: os multifuncionais. Esses indivíduos são caracterizados por exercerem diversas funções dentro de sua área de trabalho, o que apesar de ser benéfico do ponto de vista organizacional, possui efeitos mercadológicos e sociais, como a diminuição do número de vagas de trabalho no mercado e questões ligadas à saúde do trabalhador que exerce essa multiplicidade de funções: 
O trabalhador multifuncional garante à empresa não só o aumento da produtividade, mas a eficiência da mesma, além de diminuir o número de trabalhadores formalmente contratados, diminuindo os custos. Em contrapartida, a multifuncionalidade rebate negativamente no trabalhador ao impingir um ritmo de trabalho mais intenso, com pressão mental e física do trabalhador, acarretando grandes riscos e danos a sua saúde. Ademais, a multifuncionalidade provoca a baixa de vagas de emprego, uma vez que um só trabalhador executa inúmeras atividades laborativas, inclusive com desvios de funções. O processo multifuncional de trabalho gera também a instabilidade da garantia de direitos, já que essa multifuncionalidade ocorre sem aparatos legais que subsidiem o trabalhador na busca da garantia dos direitos trabalhistas por ultrapassar as funções nas quais foram contratados. (SILVA, ALMEIDA, 2017, p. 11)

Assim, a realização de diversas funções por parte de um só trabaIhador vem como uma nova modalidade de exploração nas relações trabalhistas no capitalismo que agrava as desigualdades já existentes e privilegia a acumulação de capital em detrimento da condição do indivíduo. É o caso de um dos indivíduos entrevistados, um jovem de 20 anos que possui renda de 2 a 3 salários-mínimos (valor acima da média para sua faixa de idade). Ele diz que possui problemas para conciliar trabalho, vida pessoal e curso superior, pois em épocas de maior demanda, trabalha 18 horas seguidas, das 5 da manhã até as 23 horas, mesmo aos fins de semana.

\section{O trabalhador escravo no brasil}

Continuando a busca para ilustrar a pluralidade de formas laborais no país, deve-se incluir a raiz inegável, e possivelmente a mais expressiva, da desigualdade no sistema capitalista: a escravidão. Para Vitorino (2013) e Franco (1984), no passado havia uma tendência da escravidão de representar uma situação contraditória no capitalismo, pois os indivíduos que estavam engajados na produção do mercado não participavam do movimento de circulação de mercadorias. 
Franco (1984) ilustra como trabalho escravo se difere de trabaIho livre sendo eles duas facetas da estrutura do capitalismo, que se apropria do excedente do trabalho não pago e perpetua a mais-valia. Na perspectiva do autor, é impossível trabalho livre sem escravo, visto que a escravidão era a condição para o desenvolvimento do trabalho livre na metrópole durante os séculos XVIII e XIX, ou seja, imprescindível para a construção de uma economia na época. Porém, a má utilização do potencial da mão de obra livre na época pós-abolição foi o que impediu o desenvolvimento da mão de obra assalariada.

Tal prática, ainda que tão perversa, permanece em uso na sociedade brasileira, aprofundando as marcas da desigualdade já existentes, inclusive no meio empregatício. Apesar de apresentar diferenças quando comparada à escravidão colonial, a contemporânea é tão impiedosa quanto e está longe da extinção no país: são estimadas cerca de 369 mil pessoas no Brasil vivendo nessa situação (GLOBAL SLAVERY INDEX, 2016). Porém, esse número pode ser superior graças à ilegalidade e às situações fragilizadas em que os indivíduos se encontram.

É importante ressaltar que os danos psicológicos, físicos e emocionais que esse indivíduo sofre são imensuráveis, dada a natureza de seu trabalho e as condições sobre ele impostas. Do ponto de vista econômico, ele age como um agente que contribui para o aumento de produção, mas não é capaz de consumir, dada a quantidade irrisória a qual é pago - se esse pagamento de fato ocorrer - e a quantidade de horas trabalhadas.

\section{Preconceito racial contra o trabalhador}

o racismo é definido como a crença na presença de uma hierarquização entre as diversas raças, o que determina uma relação de poder entre as classes raciais (PRUDENTE, 1989). No caso do Brasil, a mescla cultural que compõe o país cuja maioria da população não se considera branca não foi o suficiente para frear a segregação - um país que mistura o preconceito com a falsa cordialidade, derivado em grande parte da escravidão colonial e fator marcante para a instauração do racismo no imaginário do país. 
Atualmente, o preconceito é crime definido pela Lei $\mathrm{n}^{\mathrm{o}} 7.716$ (BRASIL, 1989). Porém, encontra-se mais velado que outrora e se reflete em um preconceito institucionalizado, menos explícito, mas que demonstra a "ambiguidade presente no pós-abolição - ao negro não é negado o direito de ser livre, mas lhe são negadas condições dignas de vida" (NUNES, 2006, p. 89). Fatores como renda e educação demonstram essa problemática: pretos e pardos possuíam renda média cerca de 41,7\% menor que a dos brancos (IPEA, 2015) e 17,4\% dessa população possuía ensino superior, contra 44,2\% dos autodeclarados brancos (IBGE, 2018). Ambos os padrões repetiram-se na pesquisa de campo realizada e ilustram o racismo institucional na sociedade brasileira:

compreenderemos o racismo institucional, também denominado racismo sistêmico, como mecanismo estrutural que garante a exclusão seletiva dos grupos racialmente subordinados - negr@s, indígenas, cigan@s, para citar a realidade latino-americana e brasileira da diáspora africana - atuando como alavanca importante da exclusão diferenciada de diferentes sujeit@s nestes grupos. Trata-se da forma estratégica como o racismo garante a apropriação dos resultados positivos da produção de riquezas pelos segmentos raciais privilegiados na sociedade, ao mesmo tempo em que ajuda a manter a fragmentação da distribuição destes resultados no seu interior. $\mathrm{O}$ racismo institucional ou sistêmico opera de forma a induzir, manter e condicionar a organização e a ação do Estado, suas instituições e políticas públicas - atuando também nas instituições privadas, produzindo e reproduzindo a hierarquia racial. (GELEDÉS, 2016, p. 17)

Dentro do preconceito racial, há nuances que podem afetar a realidade do indivíduo, o que abre pretexto para a discussão sobre o colorismo (SILVA e SILVA, 2017), derivado da "ideologia de branquitude", que valoriza a cor do mestiço:

Embora o racismo exista como forma de discriminação baseada em diferentes origens étnicas, o colorismo surge como uma maneira de exclusão social que considera as diferentes tonalidades de pele, 
segregando aqueles que possuem uma tonalidade da pele mais escura. (SILVA e SILVA, 2017, p. 1)

Ao se discutir raça, a questão do indígena também deve ser levantada. Desde 1500, os índios sofrem com escravidão, trabalho árduo e doenças epidemiológicas, como as trazidas pelos europeus no início da colonização e o novo coronavírus, que teve efeito profundo na realidade dessa população. Além disso, a catequização interferiu em sua identidade cultural e serviu para impor os costumes europeus aos nativos (PAIVA, 1982).

\section{Preconceito contra a mulher}

Graças à prevalência da estrutura patriarcal em grande parte da sociedade, desde o trabalho arcaico ao moderno, a mulher foi colocada em uma posição inferior à do homem em questão de poder na sociedade. Isso se exterioriza no meio empregatício por rendas menores: o rendimento médio no primeiro trimestre de 2020 foi de 2.274 reais para as mulheres e 2.888 reais para os homens (IBGE, 2020c). Isso se dá apesar de as mulheres formarem a maior parte da população com ensino superior, demonstrando a dificuldade de se inserir em cargos de alta gestão ou políticos (IBGE, 2018), e de diversas tratativas tomadas pela legislação do país que proíbe a distinção salarial baseada em gênero e prevê direitos como licença-maternidade remunerada.

Essa discrepância pode derivar do que as leis brasileiras tentam prevenir ao assegurar os direitos da mulher: o receio do empregador de perder parte de força de trabalho por uma gravidez ou maternidade e o preconceito contra a mulher, que ainda é vista pelo estigma do "sexo frágil".

\section{Preconceito por orientação sexual ou identidade de gênero}

Apesar de algumas culturas encararem a diversidade sexual e a homossexualidade desde a Antiguidade como algo intrínseco ao ser humano (REINKE et al., 2017), a orientação sexual de um indivíduo é um 
tema com opiniões divergentes que causa discussões desde a esfera social até a política.

Diferente dos outros fatores que podem levar à discriminação, a orientação sexual ou a identidade de gênero possuem um agravante no fato de o indivíduo ter a possibilidade de não tornar pública essa característica. Apesar do sofrimento psicológico que pode acarretar, isso pode parecer uma saída frente aos atos preconceituosos que ocorrem na sociedade, levando a uma dificuldade de se impor como um sujeito de direito à liberdade e à igualdade, ou ser fruto de um preconceito internalizado (NUNAN, JABLONSKI, FÉRES-CARNEIRO, 2010), reflexo da sensação de falhar em algo significativo.

Para promover uma realidade mais inclusiva, a discussão acerca da sexualidade se intensificou nos currículos escolares durante a década de 1970, propondo uma reformulação do papel da escola, tão como a sua adequação às mudanças comportamentais que ocorreram com o passar do século XX. Com isso, vê-se a tendência de que o tópico se torne menos polêmico à medida que a educação sexual é difundida nas instituições de ensino. Porém, há uma parcela expressiva correspondente a $18 \%$ da população brasileira que ainda desencoraja a homossexualidade (DATAFOLHA, 2018).

\section{Preconceito por classe social}

Unindo-se às discriminações ligadas a aparência e deficiência, há a que é dada pela classe social a qual o indivíduo pertence, que pode ser considerada um motivo de julgamento perante a sociedade:

De acordo com Markus e Fiske (2012), as diferenças entre as pessoas em termos de recursos financeiros e de capital cultural moldam as oportunidades e a forma como as pessoas se comportam. A classe social influencia desde comportamentos individuais, a exemplo do tipo de música que uma pessoa escuta, o que ela come e como fala, as relações interpessoais e interações sociais que a pessoa mantém, até fatores mais amplos, como a expectativa de vida. Portanto, a classe social se constitui uma das formas mais poderosas através 
da qual a sociedade classifica e estratifica seus membros, moldando a identidade das pessoas. (LIMA, 2016, p. 42)

Vendo que o fator econômico familiar é um determinante na ascensão monetária de um indivíduo (ESTUDO REVELA QUE..., 2019), a tendência é que os filhos possuam a mesma faixa de renda que os pais, o que demonstra o problema de mobilidade social na realidade de um país que possui nas classes um grande modelo de discriminação. Ao utilizar o poder econômico do indivíduo como método de classificação, o dinheiro possui uma capacidade de influenciar a forma como ele é visto pela sociedade, mais até mesmo do que algum preconceito que ele possa sofrer. É importante ressaltar que esses preconceitos não se excluem e, dentro de uma realidade pessoal, diversos deles podem coexistir.

Além dos tipos de discriminação já expostos acima, há outras formas de preconceito nas relações de trabalho: idade, doenças (comum em casos de portadores de HIV), por serem filiados sindicais ou possuírem determinada opinião política, por possuírem reclamações trabalhistas, e, até mesmo, estética. Portanto, deve-se trabalhar para criar uma sociedade na qual os membros possam ter a liberdade de ser quem são e, para isso, há uma necessidade de mudança na forma como as leis contra o preconceito são no país.

\section{Os efeitos do trabalho sobre a saúde física e mental e a autopercepção dos brasileiros}

O resultado das novas tendências do mundo do trabalho, como terceirização e flexibilidade, foi a intensificação da exploração do trabalho, que resultou em "uma relação de insegurança e instabilidade quanto ao vínculo empregatício" (SILVA; FERREIRA; ALMEIDA, 2017, p. 6). Com isso, "verifica-se que o comprometimento à Saúde do Trabalhador na contemporaneidade vem se intensificando (SILVA; FERREIRA; ALMEIDA, 2017, p. 11)". Conforme um estudo realizado pela Organização Mundial do Trabalho em 2013, 2,02 milhões de mortes são causadas por enfermidades ligadas ao trabalho todos os anos (INTERNATIONAL LABOUR ORGANIZATION, 2013). 
Ao se encontram inseridos em um mercado com alta concorrência por vagas, desemprego e tendências que apoiam a flexibilização e desregulamentação do trabalho, a situação de tensão para os trabalhadores no Brasil pode ser estopim para a ocorrência de doenças físicas ou mentais. Porém, a dificuldade de conseguir trabalhar em um país com esse cenário pode trazer a sensação que possuir algum trabalho já é o suficiente para ficar satisfeito.

Quando se fala sobre doenças - não só as derivadas do trabalho -, as mentais talvez sejam as mais difíceis de serem combatidas e reconhecidas. $\mathrm{O}$ entendimento real das doenças mentais é um difícil obstáculo a ser superado pela sociedade, que estigmatiza e discrimina aqueles que sofrem com isso, podendo causar também a autoestigmatização (ROCHA; HARA; PAPROCKI, 2015). Graças à atual situação do trabalho no país, há uma "conformação do sofrimento psíquico, além de repercussões psicossomáticas da instabilidade, do medo e da insegurança no ambiente laboral" (ROCHA; BUSSINGUER, 2016, p. 1119), que pode resultar em problemas psicológicos e incapacidade produtiva.

Dos entrevistados, $77 \%$ se diziam satisfeitos com o trabalho atual, porém $37 \%$ deles relataram possuir alguma doença física ou mental derivada dele. $\mathrm{E}$ os dados apontaram uma correlação entre maior nível de renda com o aumento da satisfação e de doenças laborais psicológicas. Dessa forma, para essa população, há o detrimento da saúde mental ao obter melhores condições financeiras. É o caso de um dos indivíduos entrevistados, um jovem de 20 anos que possui renda de 2 a 3 salários-mínimos, valor acima do comumente encontrado na sua faixa idade na amostra (de 0 a 1 salário-mínimo). Ele diz estar completamente contente com o seu trabalho, porém possui problemas para conciliar trabalho, vida pessoal e curso superior, pois chega a trabalhar 18 horas seguidas, das 5 da manhã até as 23 horas, algumas vezes sem descanso semanal:

Às vezes é coisa demais! Me sinto o dono da empresa, sendo que não ganho o suficiente pra isso, não tenho experiência e não posso sair mandando em todo mundo, mas as responsabilidades são de dono. Faço do café às decisões de produto, corro de um lado pro outro. Chega sexta-feira e eu não quero fazer nada, minha cabeça tá a mil, mas gosto de lá, ganho bem até. 
Porém, os efeitos de psicopatologias ligadas às práticas laborais, como a depressão, não podem ser ignorados: quando somada em todo o mundo, ela acumula uma perda na produtividade que custa 1 trilhão de dólares ao ano (WHO, 2019), e, derivada da sensação de conformidade, sua seriedade pode passar despercebida.

Entretanto, talvez pelo estigma das doenças mentais, a população não possui conhecimento da realidade ligada às doenças ocupacionais. Portanto, o reconhecimento, prevenção e melhoria das condições de trabalho são fatores necessários para iniciar a resolução desse problema. A identificação de atividades com potenciais fatores de risco ao indivíduo, assim como os danos causados, a criação de medidas para controlar ou eliminar a existência desses fatores, tão bem quanto a difusão da informação para os trabalhadores são imprescindíveis para a diminuição desses casos.

\section{Considerações finais}

A pesquisa apresentada buscou ilustrar os pontos teóricos e práticos a respeito do trabalho no Brasil, com foco na população de baixa renda no século XXI, considerando a história do sistema econômico capitalista e seus impactos sociais, que alteraram (e ainda alteram) o modo humano de se viver.

Analisando o seu início, a exploração esteve presente, já que na sua essência encontra-se a acumulação do capital e a lucratividade gerada pelo excedente dos esforços de produção. Seu foco não é nos indivíduos que constituem o sistema, e sim nas riquezas por eles geradas, permeando o poder de uma classe economicamente superior, e o sistema sofre metamorfoses constantes para melhor se adequar às necessidades do mercado que o compõe.

Práticas como a escravidão passaram a ser condenadas e houve a criação dos direitos trabalhistas, como jornada de trabalho e o salário-mínimo, que permitiram maior conforto e estabilidade para os trabalhadores. Porém, com as crises constantes e naturais ao sistema capitalista (ALMEIDA, ALMEIDA, 2016), as condições de trabalho sofrem mutações, que podem ou não ter o bem-estar do trabalhador em suas intenções. 
As tendências do trabalho de flexibilização, desregulamentação, terceirização, informalidade e intensificação da exploração (ANTUNES, 2014) impactam a esfera social ao se traduzirem na intensificação do trabaIho, rebaixamento salarial, multifuncionalidade do trabalhador e instabilidade empregatícia (ALMEIDA, ALMEIDA, 2016). Ser um trabalhador terceirizado, por exemplo, causa uma diminuição na remuneração na maioria das ocupações e funciona como uma barreira aos direitos trabalhistas (CAMPOS, 2016), além de aumentar a rotatividade da mão de obra, o que pode impactar negativamente o indivíduo que vende sua mão de obra, o empregador e o Estado (DIEESE, 2017).

A escravidão é um ponto importante para analisar a busca pela acumulação de capital no capitalismo e as marcas de desigualdades deixadas pelo sistema. Foi comprovado que a população negra e parda possui menor escolaridade quando comparada aos brancos, fato que se repete quando analisada a renda dessa população e evidencia a necessidade de ações afirmativas de combate à desigualdade e discriminação, social e institucional. É importante ressaltar que os preconceitos e discriminação são diversos, indo da aparência à classe social, e podem coexistir, não sendo excludentes.

Outro problema que afeta a população brasileira é o desemprego crônico, que traz com ele a escassez de oportunidades e menores níveis de renda. A falta de postos de trabalho faz com que a população recorra a medidas extremas para suprir suas necessidades básicas, trabalhando em condições que não são ideais, jornadas múltiplas de trabalho e informalidade.

Obter educação no país é igualmente difícil. Renda, infraestrutura, localização e estrutura familiar são alguns dos impedimentos encontrados pelos brasileiros ao buscar a educação adequada, que deve vir desde o início da vida estudantil, e não se tratar de esforços remediadores para a educação a nível acadêmico. O fomento à educação é o fator com maior capacidade de promover ascensão econômica e mobilidade social a longo prazo, ao oferecer uma ferramenta que pode ser usada durante toda a sua vida para conquistar melhores condições trabalhistas. O Programa Universidade para Todos (ProUni), por exemplo, obteve sucesso ao aumentar a permanência e inserção de indivíduos no ensino superior (SILVA, SANTOS, 2017), o que garante acesso a melhores 
posições de emprego, como ilustrado pela amostra entrevistada: 96\% dos que recebiam entre 3 e 5 salários-mínimos possuíam ensino superior incompleto, completo ou continuado (pós-graduação, MBAs etc.).

Porém, foi notado que há uma desconexão do trabalhador brasileiro frente a sua própria condição. Dentro da amostra analisada, poucos compreendem os malefícios do seu trabalho atual e o impacto histórico do capitalismo para moldar a sua realidade. A falta de tempo, educação, oportunidades e dinheiro foram apontados como as causas que mais afetaram a sua trajetória profissional, fatores que são os efeitos cujas origens são problemas profundos da sociedade brasileira, como a falta de infraestrutura, desemprego, discriminação e racismo. Mas, em um contexto trabalhista fragilizado, o contentamento encontrado em possuir um trabalho e condições básicas de vida mascara os acontecimentos por trás, criando uma visão imediatista por parte do trabalhador.

Além da melhoria das políticas públicas, o estímulo do consumo por meio do aumento do salário-mínimo, melhorias na regulação do trabalho assalariado e na estabilidade do funcionário são alternativas para melhorar o ritmo de crescimento econômico brasileiro (IPEA, 2015) e a vida dos brasileiros.

\section{Bibliografia}

ALMEIDA, Wallace; ALMEIDA, Vanessa. A constituição do capitalismo europeu e as raízes do subdesenvolvimento brasileiro: uma visão a longo prazo. Revista Espacios, Ciudad de Panamá, v. 38, n. 16, p. 24-98, 2017.

ANTUNES, Ricardo. Desenhando a nova morfologia do trabalho no Brasil. Estudos Avançados, São Paulo, v. 28, n. 81, 2014. Disponível em: https://bit.ly/3kAuMOh. Acesso em: 18 set. 2020.

ARRUDA JUNIOR, Antonio Carlos Matteis de. Capitalismo humanista não é socialismo. 2013. Tese (Doutorado em Direito) - Pontifícia Universidade Católica de São Paulo, São Paulo, 2013.

BRASIL. Lei $\mathbf{n}^{\mathbf{0}} \mathbf{7 . 7 1 6}$, de 5 de janeiro de 1989. Define os crimes resultantes de preconceito de raça ou de cor. Brasília, DF: Presidência da República, [1989]. 
BRASIL. Lei $\mathbf{n}^{\circ} \mathbf{1 3 . 4 6 7}$, de 13 de julho de 2017. Altera a Consolidação das Leis do Trabalho. Brasília, DF: Presidência da República, [2017].

CAMPOS, André Gambier. Impactos da terceirização sobre a remuneração do trabalho no Brasil: novas evidências para o debate. Brasília; Rio de Janeiro: Ipea, 2016.

CAMPOS, André Gambier (Org.). Terceirização do Trabalho no Brasil: novas e distintas perspectivas para o debate. Brasília: Ipea, 2018.

DATAFOLHA. 55\% são contra liberação de armas. Instituto de Pesquisas Datafolha, São Paulo, 27 out. 2018. Opinião Pública. Disponível em: https://bit.ly/368pLYT. Acesso em: 21 set. 2020.

DIEESE. Nota técnica Terceirização e precarização das condições de trabalho. [São Paulo: DIEESE], n. 172, 2017. São Paulo, 2017.

ESTUDO REVELA QUE educação impulsiona mobilidade social no Brasil. Portal FGV, Rio de Janeiro, 15 fev. 2019. Disponível em: https://bit. ly/35GJpcf. Acesso em: 27 out. 2020.

FRANCO, Maria Sylvia Carvalho. Organização social do trabalho no período colonial. In: PINHEIRO, Paulo Sérgio (coord.). Trabalho escravo, economia e sociedade. Rio de Janeiro: Paz e Terra, 1984.

GELEDÉS (coord.). Racismo institucional: uma abordagem conceitual. São Paulo: Trama Design, 2013.

GLOBAL SLAVERY INDEX. Austrália; Reino Unido; Índia: The Minderoo Foundation, 2016.

IBGE. Desemprego, 2020a. Disponível em: https://www.ibge.gov.br/ explica/desemprego.php. Acesso em: 18 set. 2020.

IBGE. Indicadores IBGE: Sistema Nacional de Índices de Preços ao Consumidor: IPCA e INPC. Rio de Janeiro: IBGE, 2019.

IBGE. Pesquisa Nacional por Amostra de Domicílios - PNAD/IBGE. Rio de Janeiro: IBGE, 2015.

IBGE. Pesquisa Nacional por Amostra de Domicílios - PNAD/IBGE. Rio de Janeiro: IBGE, 2018.

IBGE. Pesquisa Nacional por Amostra de Domicílios - PNAD Contínua/ IBGE. Rio de Janeiro: IBGE, $2020 \mathrm{~b}$.

INTERNATIONAL LABOUR ORGANIZATION. Fighting a slow and invisible killer. ILO News, Ha Tinh, 23 abr. 2013. Disponível em: https://bit. ly/3mwgzD7. Acesso em: 18 set. 2020. 
IPEA. Retrato das desigualdades de gênero e raça: Indicadores Pobreza, distribuição e desigualdade de renda. Brasília: IPEA, 2015.

LIMA, Tiago Jessé Souza de. O papel de representações de raça e classe social no preconceito e discriminação. 2016. Tese (Doutorado em Psicologia Social) - Universidade Federal da Paraíba, João Pessoa, 2016.

NUNAN, Adriana; JABLONSKI, Bernardo; FÉRES-CARNEIRO, Terezinha. O Preconceito Sexual Internalizado por Homossexuais. Interação em Psicologia, Curitiba, v. 14, n. 2, p. 255-262, 2010.

NUNES, Sylvia da Silveira. Racismo no Brasil: tentativas de disfarce de uma violência explícita. Psicol. USP, São Paulo, v. 17, n. 1, p. 89-98, 2006.

OECD. Education at a Glance 2018: OECD Indicators. Paris: OECD Publishing, 2018.

PAIVA, José Maria de. Colonização e catequese, 1549-1600. São Paulo: Cortez; Campinas: Autores Associados, 1982.

PRUDENTE, Eunice Aparecida de Jesus. Preconceito racial e igualdade jurídica no Brasil. São Paulo: Julex Livros, 1989.

REINKE, Carlos Augusto et al. Homossexualidade masculina e suas marcas históricas. Métis: História \& Cultura, Caxias do Sul, v. 16, n. 31, p. 275-290, 2017.

ROCHA, Fábio Lopes; HARA, Cláudia; PAPROCKI, Jorge. Doença mental e estigma. Revista Médica de Minas Gerais, Belo Horizonte, v. 25, n. 4, p. 590-596, 2015.

ROCHA, Sarah Hora; BUSSINGUER, Elda Coelho de Azevedo. A invisibilidade das doenças mentais ocupacionais no mundo contemporâneo do trabalho. Revista Pensar, Fortaleza, v. 21, n. 3, p. 1104-1122, 2016.

SILVA E SILVA, Tainan. O colorismo e suas bases históricas discriminatórias. Revista Direito UNIFACS, Salvador, n. 201, 2017.

SILVA, Jéssica Pereira Cosmo da; FERREIRA, Larissa dos Santos; ALMEIDA, Bernadete de Lourdes Figueiredo de. A nova organização do trabaIho e a saúde do trabalhador. In: Encontro Internacional de Política Social, 5., 2017, Vitória. Anais [...]. Vitória: UFES, 2017.

SILVA, Adriano Maniçoba da; SANTOS, Beatriz Carolini Silva. Eficácia de políticas de acesso ao ensino superior privado na contenção da evasão. Avaliação, Sorocaba, v. 22, n. 3, p. 741-757, 2017. 
SOARES, Marco Antônio Tavares. Trabalho informal: da funcionalidade à subsunção ao capital. Vitória da Conquista: Edições UESB, 2008. VITORINO, Artur José Renda. Escravidão e capitalismo, notas de leitura do modelo Sistema Colonial nos anos 1970. Revista Angelus Novus, São Paulo, n. 6, p. 37-56, 2013.

WHO. Mental health in workplace. World Health Organization, Genebra, 15 maio 2019. Disponível em: https://bit.ly/2I4I2NB. Acesso em: 30 set. 2020. 


\title{
Gestão da diversidade racial nas empresas como combate ao racismo institucional
}

\author{
Stella Martins Uchoa \\ Myrt Thânia de Souza Cruz
}

\begin{abstract}
Resumo
A população negra continua enfrentando grande dificuldade para se inserir no mercado de trabalho e conquistar seu espaço de ocupação, dignidade e pertencimento. As relações de trabalho no Brasil se estruturaram em cima da escravidão, deixando marcas que se perpetuam até os dias atuais, presentes no racismo estrutural que alimenta o racismo institucional nas organizações. A marginalização dos ex-escravizados após a suposta abolição da escravidão e a construção do mito da democracia racial são provas do enraizamento do racismo na cultura brasileira. $\mathrm{O}$ racismo institucional, que coloca as pessoas brancas em nítida vantagem em decorrência de seus privilégios, é refletido nas empresas e facilmente notado pela falta de representatividade negra no mercado de trabalho. Tal fato é explicado pelo pacto narcísico da branquitude, o que impede a contratação de profissionais negros/as, e pela construção do/a branco/a como um ser e do/a negro/a como um não ser. Visando a superação dessa diferença, as organizações passaram a adotar ações afirmativas, a fim de gerar uma reparação histórica do longo processo de escravização. Entretanto, o que é visto não passa de uma falsa ideologia de igualdade sendo vendida por essas empresas que querem se aproximar de seus consumidores, principalmente se eles forem jovens socialmente engajados. O presente capítulo objetiva visibilizar as razões da ausência da população negra no universo empresarial, sobretudo na ocupação das vagas corporativas, as necessidades de serem
\end{abstract}


inseridas, bem como propor estratégias para que as organizações realizem esse trabalho de modo efetivo. Discute os riscos de se ver ondas passageiras para a gestão da diversidade racial nas empresas como chamariz para modismos de consumo, chamando a atenção para a necessidade de mudanças estruturais na sociedade brasileira como um todo que possam desconstruir o racismo como relação de colonização no trabalho nos dias atuais.

Palavras-chave: Racismo. Mercado de Trabalho. Diversidade. Inclusão.

\section{Introdução}

Constituída pela mistura do indígena com o branco e o negro, a sociedade brasileira do século XIX, principalmente, condenava a mestiçagem com o argumento de que o resultado da mistura de duas raças seria negativo e "impuro", de modo que a população deveria manter-se branca. Assim sendo, a busca pelo embranquecimento se dá firmemente. Essa tese foi fortemente ilustrada no quadro A Redenção de Cam, de autoria do pintor espanhol radicado no Brasil Modesto Brocos (1852 - 1936), representante ilustre da arte brasileira, referenciado por décadas e influenciado pelo eurocentrismo.

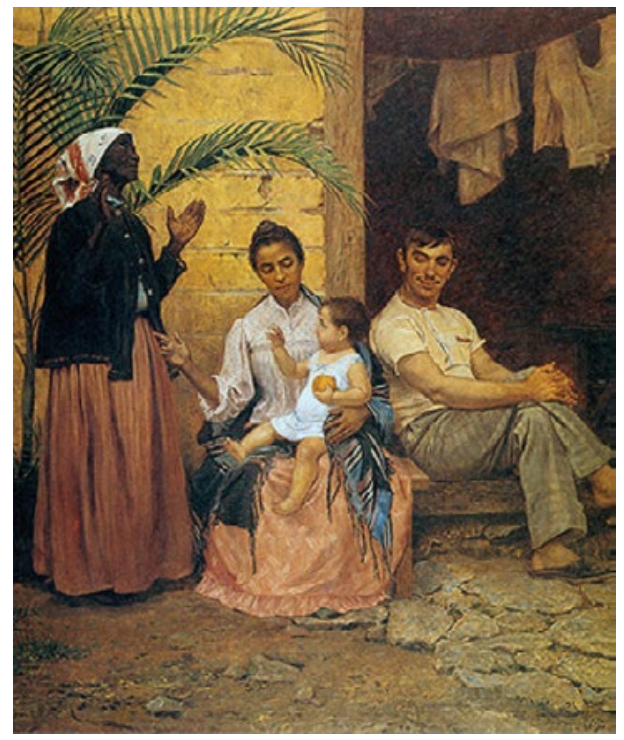

Figura 1. A Redenção de Cam, de Modesto Brocos Fonte: A REDENÇÃO DE CAM (2020). 
Durante o Congresso Universal das Raças, ocorrido em Londres em 1911, o médico brasileiro e diretor do Museu Nacional João Batista de Lacerda ilustrou seu artigo com a obra, escrevendo o seguinte texto: "O negro passando a branco, na terceira geração, por efeito do cruzamento de raças" (RONCOLATO, 2018). A tese central era de que a miscigenação trazia o benefício do embranquecimento, meta principal das autoridades e políticas brasileiras que queriam erradicar a negritude do Brasil.

Sob a ótica do sociólogo Aníbal Quijano (2005), a formação das relações sociais a partir da ideia de raça acarretou, na América, em identidades sociais historicamente novas: índios, negros e mestiços. Termos que antes referiam-se apenas à origem geográfica das pessoas, como espanhol, português e europeu, adquiriram sentido racial. As relações entre essas pessoas já eram de dominação, então essas identidades foram se associando a hierarquias e papéis sociais, acarretando o padrão de dominação vigente até então.

Ainda conforme Quijano, o trabalho pago era privilégio somente dos brancos. Até nos dias atuais, é fácil de identificar a disparidade de negras e negros no mercado de trabalho em comparação às pessoas brancas, seja pelo alto nível de desemprego, pelos salários historicamente inferiores e, principalmente, pela falta de representatividade em cargos mais altos das empresas.

A pesquisa Perfil Social, Racial e de Gênero das 500 maiores empresas do Brasil e suas ações afirmativas (INSTITUTO ETHOS, 2016) apenas confirmou tal disparidade. Um dos resultados foi a alta concentração de negras e negros em baixos níveis hierárquicos, contrapondo a maioria de brancos no topo, conforme ilustra Tabela 1.

Tabela 1. Distribuição do Pessoal por Cor ou Raça (\%)

\begin{tabular}{|l|c|c|}
\multicolumn{1}{|c|}{ Nível } & Brancos & Negros \\
\hline Conselho de Administração & 95,1 & 4,9 \\
\hline Quadro Executivo & 94,2 & 4,7 \\
\hline Gerência & 90,1 & 6,3 \\
\hline Supervisão & 72,2 & 25,9 \\
\hline Quadro Funcional & 62,8 & 35,7 \\
\hline Trainees & 41,3 & 58,8 \\
\hline Estagiários & 69,0 & 28,8 \\
\hline Aprendizes & 41,6 & 57,5 \\
\hline
\end{tabular}

Fonte: Adaptado de Instituto Ethos (2016). 
Essa alta presença em cargos de aprendizes, por exemplo, que não se manifesta em cargos de alta gerência, só reforça a sub-representação negra no mercado de trabalho: apesar de entrar em uma empresa, não conseguem alcançar melhores postos de trabalho. O que é muito visto hoje com as ações de diversidade é esse quadro sendo reafirmado, uma vez que contratando negras e negros para estágio, por exemplo, as organizações estão reproduzindo a tendência de concentrar esses profissionais na base da pirâmide, ou seja, em cargos iniciais. Isso porque apenas a contratação não acaba com o problema da desigualdade em si, é preciso também treinar, desenvolver e de fato incluir essas pessoas nas empresas.

Dessa forma, este artigo que é resultante de pesquisa de Iniciação Científica do curso de Administração procura problematizar as dificuldades, avanços, entraves e desafios em implementar políticas de ações afirmativas nas empresas. Atualizando os dados da pesquisa realizada em 2019, intitulada "As necessidades e os desafios das empresas brasileiras para incluir negros em seu quadro de funcionários e como fazê-lo de modo efetivo", e problematizando questões ocorridas no Brasil em 2020, o presente capítulo procura trazer à tona os desdobramentos da gestão da diversidade racial nas empresas como forma de combate ao racismo institucional arraigado e reiterado pelo racismo estrutural historicamente construído na sociedade brasileira. Embora a proposta não seja fazer recorte de gênero, é necessário reconhecer as interseccionalidades que estão presentes nessa discussão agravadas pelos marcadores sociais da diferença decorrentes da desigualdade social do país, como gênero e classe.

\section{A construção do mito da democracia racial e os pre- juízos causados por essa ideologia}

A afirmativa de que "Todos os seres humanos nascem livres e iguais em dignidade e em direitos", da Declaração Universal dos Direitos Humanos (ONU, 1948), garante a igualdade formal, aquela expressa em norma, mas não a igualdade material, ou seja, a que assegura oportunidades iguais às pessoas. 
Os dados de 2018 divulgados pelo Instituto Brasileiro de Geografia e Estatística (IBGE) mostram que o Brasil definitivamente não é um país racialmente democrático, como muitos ainda acreditam. Assim como o total da população brasileira, pessoas pardas ou pretas constituem também a maior parte da força de trabalho, somando 57,7 milhões de pessoas, ou seja, 25,2\% a mais do que a população branca, que totalizava 46,1 milhões. Entretanto, o rendimento médio mensal foi de R\$ 2.796 para pessoas brancas e $\mathrm{R} \$ 1.608$ para pretas ou pardas, ou seja, 57,5\% menor para o segundo grupo (IBGE, 2018). Olhando a distinção entre ocupação formal e informal, fica mais nítida essa diferença:

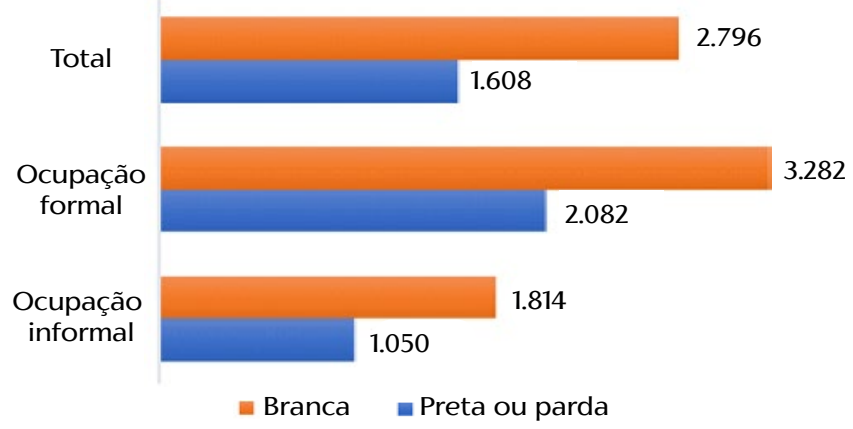

Gráfico 1. Rendimento médio real habitual do trabalho principal das pessoas ocupadas (R\$/mês)

Fonte: Adaptado de IBGE (2018).

Já no quesito educação, os números são diferentes. A taxa de analfabetismo de pessoas de 15 anos ou mais de idade era de 18\% para pessoas brancas e $36,6 \%$ para pretas e pardas, uma diferença maior que o dobro.

Apesar das estatísticas mostrarem a realidade, a ideia de pessoas brancas e negras serem iguais ainda é forte na mente popular e ganhou força, sistematização e status científico com a publicação de Casa-Grande \& Senzala, de Gilberto Freyre, em 1933, conforme aponta Bernardino:

Embora Freyre destaque o caráter sadomasoquista da cultura brasileira, o sadismo da casa-grande personificado no senhor de engenho e o masoquismo da senzala materializado na figura do 
escravo, o tom da sua obra é de otimismo em relação a um ambiente social gestado durante a fase colonial brasileira que favorece e é propício à ascensão social do mulato, tipo que tenderia a caracterizar num futuro próximo o Brasil. (BERNARDINO, 2002, p. 251)

Com essa obra, Freyre cunhou o mito da democracia racial, passando a ideia de que não existia racismo no Brasil, o que foi aceito tanto externa como internamente.

Florestan Fernandes (2017) aponta que a situação racial brasileira foi elaborada ao longo do desenvolvimento do modo de produção escravista, que encarou o escravizado como mera mercadoria. Nesse contexto, negras e negros eram excluídos e não eram considerados seres de direitos e deveres. O preconceito e a discriminação foram utilizados para manter a supremacia branca, de modo a criar barreiras para a ascensão da população negra nos empregos, na educação e na economia.

Com a Lei Áurea de 13 de maio de 1888, que simbolizou a teórica libertação dos escravizados, essas pessoas foram expulsas do sistema de trabalho, pois priorizou-se a escolha de imigrantes em detrimento de ex-escravizados aos postos de trabalho.

Em decorrência disso, quem não conseguiu retornar às regiões de origem viu o trabalho livre oferecido como uma continuidade do regime de escravidão de forma diferente, e era tido como "vagabundo" e "parasita" por não trabalhar. Aos homens era designado o trabalho sujo, arriscado e mal pago. Para as mulheres, mantinha-se a tradição doméstica, além de muitas vezes a prostituição, como única forma de sobreviver.

Conforme Carneiro (2011), o acesso ao trabalho é a condição primordial para a reprodução da vida, e a exclusão é a primeira forma de negação de tal direito básico da cidadania. O cenário desenhado acima foi uma das heranças da escravização e tem impacto direto na situação do mercado de trabalho contemporâneo brasileiro. A discrepante situação entre brancos e negros no universo empresarial é histórica e necessita de trabalho intensivo para ser reparada. As políticas de ações afirmativas configuram o melhor meio para essa mudança.

Negros com as mesmas capacidades que brancos são preteridos em processos seletivos e, quando igualmente empregados, ganham menos realizando a mesma função (CARNEIRO, 2011). Em decorrência 
disso, constata-se que a gestão da diversidade nas empresas não é um tema em alta, mas necessário de se colocar em prática e de modo efetivo para garantir a inclusão, capacitação e promoção de profissionais negros. Para tal, é preciso contextualizar o universo corporativo sobre as desigualdades entre as populações negra e branca.

\section{Racismo institucional e políticas de ações afirmativas}

O racismo desencadeia relações sociais profundamente desumanas e, quando perpassa o cotidiano das instituições, a situação torna-se ainda mais complexa. À medida que o crime de discriminação racial é cometido no anonimato e não pode ser atribuído ao indivíduo isoladamente, enraíza-se o racismo institucional (EURICO, 2011).

Para acabar com essa prática nas empresas, é preciso, em primeiro lugar, reconhecer a reprodução interna desse racismo para, a partir de então, conscientizar e mobilizar o quadro de funcionários sobre essa problemática e literalmente ensinar os profissionais que isso é errado e que não deve ser feito.

Ainda de acordo com Eurico (2011), as ações afirmativas são o conjunto de políticas públicas e privadas de caráter compulsório, facultativo ou voluntário, formadas para combater a discriminação, seja ela racial, de gênero, por deficiência física ou de origem nacional. Nesse sentido, as políticas de ação afirmativa de combate ao racismo no mercado de trabalho têm como objetivo assegurar igualdade material entre as pessoas no que se refere a oportunidades de emprego, desenvolvimento profissional e carreira.

\section{Pacto narcísico da branquitude}

"A racionalidade do branco é vivida como um círculo concêntrico: a branquitude se expande, se espalha, se ramifica e direciona o olhar do branco" (BENTO, 2002, p. 47). Nesse sentido, a branquitude certifica privilégio social e mascara profundas desigualdades, configurando o racismo como problema de negros, por exemplo. 
O pacto narcísico da branquitude, formado através de vieses inconscientes de recrutadores e selecionadores - profissionais de Recursos Humanos (RH) -, manifesta-se no ambiente de trabalho. Ele reforça as barreiras de acesso de negras e negros ao mercado de trabalho e, muitas vezes, é expresso de forma que nem os próprios profissionais de RH percebam que o cometem. Isso se deve a toda uma construção sociocultural de cada pessoa, do que ela aprende no decorrer da vida, se ela tem a mente aberta a novas questões, se ela lida com a questão diariamente (no caso, se ela é uma pessoa negra) etc.

Gevanilda Santos afirma que, "[a]o longo dos séculos, os brasileiros se acostumaram a expressar juízo de valor estereotipado sobre a aparência e cultura do negro brasileiro" (2009, p. 23). A autora defende também que "[o] efeito mais perverso do racismo é inibir a participação social em todos os níveis da cidadania plena" (SANTOS, 2009, p. 24).

Nas décadas de 1980 e 1990, o ideal antirracista travou uma guerra ideológica com as instituições brasileiras com o objetivo de conquistar maior participação social, isonomia econômica e valorização de sua identidade.

Em 1988, centenário da chamada abolição da escravatura, sindicatos e alguns setores empresariais tiveram que lidar com a reivindicação de melhoria da situação negra no mercado de trabalho baseada nas estatísticas, que mostravam o alto índice de desemprego, iniquidade salarial e práticas racistas no processo de admissão. Inclusive, para alguns cargos, era naturalmente exigido ter uma "boa aparência", padrão de beleza intencionalmente europeu que tem as mulheres como as maiores vítimas.

Para romper com essa escolha narcísica nos processos de recrutamento e seleção é preciso que exista uma consciência, por parte dos profissionais de $\mathrm{RH}$ e das empresas, sobre a realidade de desigualdade racial vigente no país, bem como sobre o papel da organização de acabar com esse ciclo. Além disso, ter as atribuições bem definidas dos cargos e características específicas exigidas dos candidatos são boas práticas. Assim, é possível reduzir as chances de o recrutador de avaliar e escolher uma pessoa sem critérios concretos e com base nos seus vieses inconscientes de raça. 


\section{Sobre gestão da diversidade racial e sua importância nas empresas}

A inclusão de pessoas negras no mercado de trabalho torna-se imperativa em função dos quatro séculos de exclusão que separam negros e brancos em um abismo social evidenciado pelas estatísticas. Esse processo, conforme explica Mattos (2013), configurou como norma a criminalização do negro em todas as tentativas de organização social para o enfrentamento dos dilemas pós-abolição. Segundo a autora, "Se não se obriga ao trabalho, reprime-se a vadiagem, gritaram então as folhas locais, ainda em 1888. Esta seria a máxima do liberalismo oligárquico republicano" (MATTOS, 2013, p. 281). Dessa forma, esse processo de criminalização obrigou negros a procurarem alternativas para a inserção no mundo do trabalho, perpassadas por marcadores sociais que tinham como meta criminalizar para encarcerar ou manter sob vigilância e punição. Assim, a população negra se constitui como os principais ocupantes do sistema carcerário e, posteriormente, do sistema manicomial, conforme Arbex (2013).

Muito mais do que uma onda passageira, modismo ou algo assim, a gestão da diversidade se insere num campo de luta pelos direitos e igualdades proporcionados pela Constituição de 1988. Aguerre (2019) enfatiza a importância dos movimentos sociais e democráticos que lutaram pelas políticas públicas de inclusão e luta pela igualdade social no Brasil, de modo que a gestão da diversidade no país possui peculiaridades e particularidades atravessadas pela história.

Como eco global, os movimentos brasileiros beberam nas fontes da Declaração Universal dos Direitos Humanos, proposta pela Organização das Nações Unidas no pós-guerra, em 1948. Também receberam as influências das pactuações da Organização Internacional do Trabalho (OIT) e, nas questões raciais, bebeu nas fontes dos movimentos pelos Direitos Civis nos Estados Unidos. Porém, há que se pensar e estudar a própria realidade brasileira, que impõe desafios específicos, sobretudo para reconhecer que o racismo existe e que produz obstáculos que dificultam e/ou impedem que a pessoa negra seja inserida no mercado de trabalho e nele cresça e se desenvolva.

De acordo com Azevedo, Silva e Conceição: 
Sabemos que essa segmentação racial não resultou, como muitos querem acreditar, de uma qualificação ou incapacidade inicial dos negros: a relativa falta de qualificação que esse grupo apresenta hoje, quando comparada ao grupo de brancos, é efeito - e não causa - do tratamento desigual que sempre recebeu, não apenas no âmbito organizacional, mas nas relações cotidianas historicamente informadas pelo racismo. (AZEVEDO; SILVA; CONCEIÇÃO, 2019, p. 124)

Os autores destacam a importância do planejamento e implementação dos programas de gestão da diversidade que realmente incluem mulheres e homens negros no ambiente corporativo para que esse quadro seja revertido, de modo que o papel das empresas seja marcadamente estratégico.

Fica evidente, então, que para inserir pessoas negras no mercado de trabalho, as empresas devem considerar os condicionantes sócio-históricos que moldaram as relações de trabalho no Brasil e pautar-se nesse cenário para estruturar suas políticas de ações afirmativas.

Estratégias para inclusão de negras e negros no mercado de trabalho

É papel do RH das empresas fazer com que as práticas de diversidade racial dialoguem com todas as áreas de negócio, levando o tema para todos os funcionários, principalmente da alta direção, pois "sem chefes que dão o exemplo, a luta pela inclusão não consegue avançar" (VOCÊ RH, 2019, p. 30). Como primeiro passo para a mudança, é essencial entender o contexto atual da organização, mensurando a proporção de pessoas negras, além de saber como se dá essa distribuição entre áreas e cargos. $\mathrm{O}$ resultado desse levantamento pode dizer muito sobre a empresa e nortear suas estratégias, definindo objetivos e metas.

Para ter um ambiente que valoriza a diversidade, é preciso criar uma cultura organizacional que viabilize isso. Reavaliar os valores institucionais, fazer treinamentos, eventos e rodas de conversa para discutir sobre racismo e discriminações com os funcionários é uma boa forma de ensiná-los sobre essa realidade, bem como sobre o que é certo e o que é errado. 
O apoio e dedicação da liderança é essencial, entretanto, todo líder precisa ser preparado para ser um exemplo a ser seguido. Palestras, treinamentos e mentoria reversa, no qual grupos minoritários compartilham suas experiências de forma a ilustrar as dificuldades que enfrentam, são aliados para sensibilizar e quebrar preconceitos.

Os processos de recrutamento e seleção precisam ser mais inclusivos e evitar ao máximo os vieses inconscientes dos profissionais de RH. A prática de recrutamento às cegas, em que informações pessoais como cor, gênero, curso e faculdade dos candidatos são omitidas, permite que a cor da pele não seja uma barreira para a entrada no mercado de trabalho. Buscar talentos em locais apropriados também é vantajoso. Se a meta é contratar pessoas negras, investir em serviços de consultoria especializada em inclusão ajudaria a empresa tanto a fazer a coisa certa quanto de forma certa. Rever as habilidades exigidas para os cargos, como retirar a fluência do idioma inglês, pode fazer com que o anúncio da vaga alcance mais pessoas.

Tendo em vista que a mera contratação de pessoas negras não resolve o problema em si, é preciso criar formas para que profissionais negros desenvolvam-se no ambiente corporativo, alcançando altos cargos e melhorando sua carreira. A retenção desses novos talentos é um fator muitas vezes esquecido, mas uma vez dentro do ambiente corporativo, o profissional precisa de um plano de carreira que considere os possíveis obstáculos para que ele não fique estagnado nem seja desligado quando o contrato acabar. Um plano de carreira associado à mentoria com gestores e conversas frequentes com o RH para feedbacks e sugestões de melhoria mantém a empresa próxima a esses talentos, sabendo quais são suas percepções, dificuldades e exigências.

Os grupos de afinidade, em que funcionários negros se unem para conversar sobre o que passam dentro e fora da empresa, é um bom caminho para que eles não fiquem sozinhos, para que se apoiem e, principalmente, proponham melhorias à organização. Afinal, a dor é deles e eles sabem do que estão falando.

Ter métricas nítidas e sempre acompanhar os resultados é necessário para saber se a empresa está fazendo uma gestão da diversidade racial efetiva, porque afirmar ser diversa não é o suficiente, é preciso dizer quanto. 
Por fim, para garantir suporte a profissionais negras e negros, um canal de denúncias, de preferência uma ouvidoria externa, precisa estar disponível para que brincadeiras, comentários, piadas e qualquer situação de discriminação tenha o autor punido e a segurança e o respeito de todos sejam assegurados.

Há dois grandes exemplos para ilustrar como essas estratégias funcionam na prática. A empresa Johnson \& Johnson, que está num momento inicial de gestão da diversidade, criou o grupo de afinidade SoulAfro para trazer à tona a necessidade de inclusão de profissionais negros, além de empoderar os funcionários da organização, dando voz a eles. Uma das iniciativas do grupo foi a Semana da Consciência Negra, que levou informações sobre a realidade negra no mundo do trabalho para toda a empresa (JOHNSON \& JOHNSON CARREIRAS, 2019).

Além disso, a companhia convidou uma professora para dar uma aula de história que abordou pontos importantes sobre racismo estrutural, interseccionalidade, ancestralidade e representatividade. Comidas de origem afro, como vatapá e acarajé, foram servidas no restaurante da empresa para reforçar a ancestralidade. E, por fim, foi divulgado um material chamado "Pitadas de Consciência", promovendo o letramento racial das equipes, ensinando que expressões como "denegrir" são racistas e não podem ser usadas, além de dar sugestões de substituições. Também foi planejada uma série de ações que ajudarão a equipe de Aquisição de Talentos a estruturar programas para profissionais negros, como mentorias.

Já a Bayer, empresa química e farmacêutica, já tem uma política de gestão de talentos que é guiada por princípios para que cada colaborador tenha a oportunidade de se desenvolver profissionalmente. Ela incentiva os gestores a se engajarem ativamente no desenvolvimento de suas equipes e motiva os colaboradores a serem protagonistas de seu próprio crescimento. Também há um grupo de afinidade, o BayAfro, que tem como objetivo construir uma empresa cuja população interna reflita a distribuição negra da sociedade brasileira em todos os níveis hierárquicos (BAYER, 2019). Para isso, o grupo desenvolve e discute políticas de inclusão e aceitação, estratégias de comunicação e treinamentos sobre o tema da afinidade racial. Após a adoção dessas estratégias, o índice de pessoas negras trabalhando na empresa aumentou 
para $21 \%$. O sistema de cotas adotado mostra que ela tem mais funcionários negros em grupos de estagiários, o que permite que o $\mathrm{RH}$ se concentre em encontrar mais candidatos negros e direcionar cargos maiores para pessoas negras.

\section{Considerações finais}

A pesquisa evidenciou a relevância das práticas de gestão da diversidade que utilizam políticas de ações afirmativas como enfrentamento ao racismo institucional que historicamente impera nas organizações brasileiras. No entanto, tais ações de forma isolada não são suficientes para mitigar os efeitos perversos do racismo antinegro que estruturalmente se construiu e se reifica na atualidade. Espera-se muito mais das corporações, que elas se comprometam com a erradicação do racismo, do machismo, da homofobia e outras pautas interseccionais que se erguem como muros no mundo do trabalho. Espera-se um pacto das corporações com a sociedade e os governos na medida em que nenhuma ação prescinda desse compromisso mútuo e corajoso que impulsione mudanças significativas necessárias para as demandas atuais.

O mundo em 2020 já não é mais o mesmo: o isolamento social provocado pela pandemia de Covid-19 nos confronta cotidianamente com nossos medos e questões subjacentes que tradicionalmente eram varridas para debaixo do tapete. Em um movimento impulsionado pelas denúncias frequentes na mídia, a misoginia organizacional e o racismo têm sido escancarados. Empresas estão sendo pressionadas pela sociedade e pelos consumidores em direção a um posicionamento nítido a respeito do racismo. Assim, as políticas internas estão sendo revistas em muitas companhias, sobretudo as globais, no sentido de elaborarem processos seletivos mais justos e inclusivos e que considerem as condicionantes sociais e as interseccionalidades que abrangem boa parte das brasileiras e dos brasileiros. Santos elucida muito bem essa questão:

Em razão da forma como se deu o processo de abolição no Brasil, não incluindo a população negra no seu desenvolvimento econômico, através de ações políticas voltadas a esse objetivo, como também 
em razão do mito da 'democracia racial', que sempre foi obstáculo, uma vez que a discriminação racial existiu chegando-se ao patamar de racismo impregnado nas instituições, tais práticas justificam a necessidade de políticas de ações afirmativas, com a finalidade de incluir a mulher negra nas relações de trabalho em igualdade de oportunidades. (SANTOS, 2020, p. 207)

Pode-se afirmar que a gestão da diversidade racial e as práticas inclusivas no Brasil ainda são embrionárias. Existem empresas que já praticam e encaram a questão com a seriedade necessária, porém, são exceções. Um longo trajeto está por vir, obstáculos são colocados no caminho, como a ausência de políticas públicas nessa direção, além de resistências por parte de setores da economia que ainda produzem e reproduzem o discurso da meritocracia como medida de todas as coisas. Assim, restam lutas incessantes na direção da conscientização, na promoção da didática inclusiva e, sobretudo, há que se investir no quadro de lideranças do futuro para que entendam o compromisso ético e político das organizações nesse processo.

\section{Bibliografia}

AGUERRE, Pedro. Políticas públicas, diversidade e desenvolvimento social: desafios para as organizações. In: CAMILO, Juliana. FORTIM, Ivelise; AGUERRE, Pedro. Práticas de gestão da diversidade nas organizações. São Paulo: SENAC, 2019.

ARBEX, Daniela. Holocausto Brasileiro. São Paulo: Geração Editorial, 2013. A REDENÇÃO DE CAM. In: Enciclopédia Itaú Cultural. São Paulo: Itaú Cultural, 2020. Disponível em: https://bit.ly/32NC6zu. Acesso em: 12 jul. 2020.

AZEVEDO, Amailton Magno; SILVA, Adriana Maria de Souza; CONCEIÇÃO, Eliane Barbosa. Reflexões sobre o racismo: desigualdade, raça e gênero no mundo do trabalho. In: CAMILO, Juliana. FORTIM, Ivelise; AGUERRE, Pedro. Práticas de gestão da diversidade nas organizações. São Paulo: SENAC, 2019. 
BAYER. Inclusão e Diversidade. Bayern Carreiras Brasil, São Paulo, 2 maio 2019. Disponível em: https://bit.ly/3hYOwJj. Acesso em 1 jun. 2020.

BENTO, Maria Aparecida Silva. Pactos narcísicos no racismo: branquitude e poder nas organizações empresariais e no poder público. 2002. Tese (Doutorado em Psicologia) - Instituto de Psicologia, Universidade de São Paulo, São Paulo, 2002.

BERNARDINO, Joaze. Ação Afirmativa e a Rediscussão do Mito da Democracia Racial no Brasil. Revista Estudos Afro-Asiáticos, Rio de Janeiro, v. 24, n. 2, p. 247-273, 2002.

CARNEIRO, Sueli. Racismo, sexismo e desigualdade no Brasil. São Paulo: Selo Negro, 2011. (Coleção Consciência em Debate).

EURICO, Márcia Campos. Questão Racial e Serviço Social: uma reflexão sobre racismo institucional e o trabalho do assistente social. 2011. Tese (Mestrado em Serviço Social) - Pontifícia Universidade Católica de São Paulo, São Paulo.

FERNANDES, Florestan. Significado do protesto negro. São Paulo: Expressão Popular; Editora da Fundação Perseu Abramo, 2017.

IBGE. Pesquisa Nacional por Amostra de Domicílios - PNAD Contínua 2018. Rio de Janeiro: IBGE, 2018.

INSTITUTO ETHOS. Perfil social, racial e de gênero das $\mathbf{5 0 0}$ maiores empresas do Brasil e suas ações afirmativas. São Paulo: Instituto Ethos; Banco Interamericano de Desenvolvimento, 2016.

JOHNSON \& JOHNSON CARREIRAS. "Precisamos mostrar nossas histórias e nossa voz para conscientizar" - Letícia Januário, Analista Sr de Aquisição de Talentos. JNJ Carreiras Brasil, [S. I.], 14 nov. 2019. Disponível em: https://bit.ly/33PZ48b. Acesso em: 3 maio 2020.

MATTOS, Hebe. Das cores do silêncio: os significados da liberdade no Sudeste escravista. 3. ed. Campinas: Editora da Unicamp, 2013.

ONU. Declaração Universal dos Direitos Humanos. Assembleia Geral da ONU, 1948. Disponível em: https://bit.ly/3kERx2O. Acesso em 12 jul. 2020.

QUIJANO, Anibal. Colonialidade do poder, Eurocentrismo e América Latina. Buenos Aires: Conselho Latino-americano de Ciências Sociais, 2005. Disponível em: https://bit.ly/3kCocGt. Acesso em: 5 jun. 2019. 
RONCOLATO, Murilo. A tela "A Redenção de Cam" e a tese do branqueamento no Brasil. Edusp, São Paulo, 14 jun. 2018. Disponível em: https://bit.ly/2RObAzM. Acesso em: 12 jul. 2020.

SANTOS, Gevanilda. Relações raciais e desigualdade no Brasil. São Paulo: Selo Negro, 2009. (Coleção Consciência em Debate).

SANTOS, Lucinéia Rosa dos. Os direitos de igualdade da mulher negra nas relações de trabalho. In: PIMENTEL, Silvia et al. (org.). Raça e Gênero: discriminações, interseccionalidades e resistências. São Paulo: EDUC, 2020.

VOCÊ RH. Como criar empresas realmente diversas. São Paulo: Editora Abril, 62. ed., jun./jul. 2019. 66 p. 


\title{
O processo de inserção de jovens transexuais e transgêneros no mercado de trabalho: um estudo com estudantes de uma universidade confessional paulistana
}

\author{
Paloma Mota da Silva \\ Dione Fagundes Nunes Gomes
}

\begin{abstract}
Resumo
Este estudo apresenta resultados sobre uma pesquisa realizada com estudantes transexuais e transgêneros de uma universidade confessional paulistana. O objetivo foi identificar os principais fatores que interferem no processo de inclusão no mercado de trabalho encarados pelos estudantes transexuais e transgêneros da universidade pesquisada. A pesquisa qualitativa (2019), de caráter descritivo, analisou questões acerca de experiências em processos seletivos e com o mercado de trabalho dos indivíduos entrevistados. As análises realizadas confirmam que, embora se observe maior abertura no mercado de trabaIho, os transexuais e transgêneros ainda encontram dificuldades na busca por um emprego. O estudo aponta que os fatores interferentes podem ser aqueles que cercam o público ao longo de sua vida, desde a relação com a família e a vivência na escola até o preconceito existente na sociedade. Além dos fatores relacionados à vida, têm-se fatores no mercado de trabalho, como, por
\end{abstract}


exemplo, a abertura que este possui a transexuais e transgêneros - que pode variar conforme as áreas de atuação existentes.

Palavras-chave: Transexuais. Transgêneros. Estudantes.

\section{Introdução}

Para se falar em inserção de jovens no mercado de trabalho, vale começar por uma visão mais geral. Conforme Sobrosa et al. (2012), os jovens encontram maiores dificuldades para conseguir se posicionar na transição do ensino médio para a universidade ou mercado de trabalho.

A dificuldade encontrada por esses jovens normalmente é ocasionada pelos anseios que acompanham essa fase - ou seja, é comum que o jovem ingressante no mercado de trabalho sofra por alguns anseios naturais, decorrentes de diversos questionamentos, como: em qual ramo devo trabalhar? Será que vou gostar? Será que a empresa valoriza seus funcionários?

Pode-se citar, ainda, as dificuldades e angústias enfrentadas no momento da procura por um emprego - é natural que o jovem encontre dificuldades, uma vez que dele se exige estar cada vez mais qualificado e preparado para as necessidades do mercado, o que faz com que tenha angústias sobre possuir as qualificações que as empresas buscam atualmente.

Outro fator contribuinte é o desemprego. Conforme a Pesquisa Nacional por Amostra de Domicílios PNAD, a taxa atual de desemprego no Brasil é de aproximadamente 12\%, sendo que em uma das maiores faixas estão as pessoas entre 18 e 24 anos de idade (INSTITUTO BRASILEIRO DE GEOGRAFIA E ESTATíSTICA, 2019).

Além dos anseios e angústias naturais, o jovem é também influenciado pela família, dado que é comum existir uma cobrança por parte dos familiares para que o jovem inicie sua busca por um emprego logo após sua saída do ensino médio.

Ainda no âmbito familiar, a renda total dentro de casa é outro fator que contribui para que o jovem procure por um emprego - não por ser o ideal, mas por ser necessário, principalmente quando esse pertence a uma classe social de baixa renda. 
Relacionando esses fatores, é possível identificar possíveis razões que fazem com que o jovem busque por emprego logo após o término do ensino médio. Pode-se dizer que quando o jovem é negro, ou ainda com uma orientação sexual diferente da heterossexual, aumentam-se ainda mais suas dificuldades devido ao preconceito ainda hoje enfrentado por esses grupos.

Diante do exposto, interessa para este estudo responder a seguinte questão: quais fatores interferem no processo de inclusão do público transexual e transgênero universitário no mercado de trabalho?

É possível observar maior abertura no mercado de trabalho a profissionais transexuais e transgêneros devido aos diversos programas de inclusão. Entretanto, os transexuais ainda encontram muitas dificuldades para conseguir um emprego, o que pode incluir alguns fatores como: o ramo da empresa; o porte; a área desejada pelo candidato; o relacionamento com os demais profissionais da empresa pelo preconceito ainda hoje existente; o desrespeito ao nome social do transexual; a obtenção de reconhecimento da identidade de gênero a qual o profissional se enquadra, entre outros fatores. Por outro lado, têm-se presente alguns aspectos positivos que amenizam a dificuldade que poderia ser ainda maior, como ações de conscientização e caracterização do público realizadas nas empresas e a existência de grupos de inclusão que auxiliam a entrada desses profissionais no mercado de trabalho - como o Transempregos, Transcidadania etc.

O objetivo final do estudo, portanto, é identificar os principais fatores que interferem no processo de inclusão no mercado de trabalho encarados pelos estudantes transexuais e transgêneros de uma universidade confessional paulistana. Para tanto, faz-se necessário: caracterizar a população LGBTOIAP+, na qual estão inseridos os transexuais e transgêneros, destacando as principais diferenças; mapear a incidência dos transexuais e transgêneros considerados no estudo, que se encontram inseridos no mercado de trabalho; evidenciar o ramo de atividade que oferece maior acessibilidade aos transexuais e transgêneros e indicar programas voltados para a inserção do público transexual e transgênero no mercado de trabalho.

O estudo oferece informações relevantes quanto aos fatores que interferem na inclusão de transexuais no mercado de trabalho - o que 
pode contribuir para que os gestores dos programas de auxílio a profissionais transexuais e transgêneros existentes revisem os métodos utilizados em sua atuação, diminuindo a barreira à inclusão desse público no mercado de trabalho, e, ainda, para que as empresas e seus gestores optem por revisar seus métodos de contratação a fim de mostrar maior abertura a esse grupo. Por fim, podem também se beneficiar do estudo o público LGBTOIAP+ (Lésbicas, Gays, Bi, Trans, Queer', Intersexo, Assexuais/Agêneros ${ }^{2}$, Pans ${ }^{3}$ e mais), uma vez que a compreensão do fenômeno e dos fatores que os cercam poderá prepará-los para o momento da busca por uma oportunidade de emprego.

\section{Referencial Teórico}

\section{Preconceito}

Segundo Crochík (2006), o preconceito é algo que surge através de uma manifestação irracional no ser humano, e pode ser construído através da cultura ou meio no qual o indivíduo está inserido, podendo ser transmitido no decorrer das gerações.

Para se falar em indivíduo, deve-se pressupor uma esfera de intimidade ou de interioridade, que se contraponha a uma esfera de exterior, mas é uma interioridade que surge a partir desse mesmo exterior, o que implica que o indivíduo é produto da cultura, mas dela se diferencia por sua singularidade. (CROCHík, 2006, p. 15)

O preconceito tanto pode ser desconstruído por meio do processo de socialização do indivíduo (de modo que ele possa questionar-se sobre tal comportamento), como também pode ser construído a partir dele, quando o indivíduo apenas torna-se conivente com tais atitudes e as reproduz. (CABRAL, 2016)

1 Queer: pessoas que não têm definida a sua orientação sexual ou seu gênero.

2 Agêneros: pessoas que não possuem gênero.

3 Pans: pansexuais, pessoas que sentem atração por todo e qualquer tipo de gênero. 
Pode-se dizer que o preconceito está presente desde o início do processo de socialização do indivíduo. Com o gênero feminino, segundo Beauvoir (2009), o preconceito tem início a partir das pequenas imposições. O menino possui um órgão sexual que o representa e é estimulado de forma que o faz enxergar que, para si, as oportunidades são mais diversas e maiores, acreditando, assim, ser superior ao gênero feminino. A menina recebe uma boneca, que lhe é dada como uma forma de preparo para que possa desenvolver seus papéis sociais, tais como casar-se, ter filhos, e, dependendo de sua condição social, lavar, passar, costurar e outras atribuições impostas à mulher pela sociedade.

Como uma forma de equiparar as diferenças entre os gêneros, surge, em meados do século XIX, o Movimento Feminista com o objetivo de trazer para as mulheres o direito à cidadania e ao pensamento, a liberdade de expressão e igualdade perante os homens. (SAGIM, 2004)

Após o crescimento do movimento, que se deu somente no século XX, a mulher conquista o direito ao voto, a licença-maternidade e o direito de ingressar em universidades e no mercado de trabalho - sem autorização do marido. (BORIN, 2007)

Outro exemplo de preconceito é o racismo que, segundo Nunes (2010), baseando-se em registros históricos, existe desde o século XVII apesar do termo passar a ser utilizado somente no século XIX. Souza (2012) define que o racismo acontece quando uma pessoa de uma determinada raça ou etnia define uma raça/etnia diferente da sua como inferior.

Pode-se citar como exemplo de racismo o preconceito com os negros, que sofreram e foram escravizados ao longo da história somente por possuírem cores de pele diferentes, culturas diferentes etc. Segundo Domingues (2004), os negros foram segregados racialmente e considerados incapazes de executar alguns dos cargos religiosos, civis e militares da época.

Os negros cravaram diversas lutas em busca de sua liberdade, conquistada em 1888 e assinada pela Princesa Isabel (Lei Áurea). Para isso, foram necessárias ações como confrontos com autoridades, fugas dos cativeiros, negociações de relações a fim de conquistar a liberdade, enfrentamento dos senhores detentores de poder nos tribunais e outros (CUSTÓDIO SOBRINHO, 2014). 
Tratando-se do preconceito homossexual - também conhecido como homofobia e sofrido por aqueles com orientação sexual diferente, que é o público foco deste trabalho -, pode-se dizer que se fundamenta no dualismo entre a heterossexualidade e a homossexualidade. Conforme Miskolci (2009), a heterossexualidade torna-se prioridade por meio de um dispositivo que a naturaliza: a reprodução humana. Gillum e Difulvio (2012) apud Barros, Sani e Santos (2019) afirmam que existem duas formas de homofobia: a social e a internalizada. A homofobia social é caracterizada por um estigma associado a ser diferente da norma heterossexual, deixando os indivíduos cada vez mais isolados e/ou com vergonha de sua orientação sexual contribuindo para o medo e o estigma entre jovens homossexuais. A homofobia internalizada pode levar um jovem a sentir necessidade de se esconder ou negar a sua orientação sexual em uma tentativa de se enquadrar na norma heterossexual.

Atualmente, no âmbito social, foram conquistados direitos por esse público no que se refere aos direitos de ir e vir, de proteção social, ao respeito à diversidade humana, direitos humanos, da personalidade, entre outros.

Os direitos humanos possuem o dever de proteger a integridade dessa população. Trazem consigo a proteção, a defesa e a promoção, tendo como principal foco o fim da homofobia e da discriminação em razão da orientação sexual e da identidade de gênero. (MALUF, 2010)

Segundo Soliva e Silva Junior (2014), no que se trata da família, essa é parte importante para que os jovens possam construir e desenvolver suas autonomias - principalmente quando suas singularidades são valorizadas pelos familiares. Outro papel da família é o estabelecimento de diretrizes que irão nortear as expectativas sociais perante o jovem, tanto nos âmbitos sexuais e de gênero como em suas interações afetivas. Toledo e Teixeira Filho (2013) afirmam que, no intuito de seguir e cumprir as regras da heterossexualidade, os pais ou responsáveis investem fortemente para que seus filhos se tornem heterossexuais e cumpram, de acordo com seu sexo biológico, o que se espera deles. Por esses fatores, quando um filho revela ser homossexual, as reações por parte dos pais tendem a ser diversas - o que dependerá das relações mantidas entre o jovem e a família, do comprometimento que a família possui com o moralismo social, os fundamentos religiosos etc. 
Para cumprir com as premissas da heteronormatividade, as famílias investem pesadamente, e de modo inconsciente, para que seus filhos e filhas se tornem heterossexuais e façam as correspondências das performances de gênero correspondentes ao seu sexo biológico, através do dispositivo da sexualidade, com estratégias diversas de enaltecer e valorizar experiências e modos de existência que julgam levar à heterossexualidade e banir o que julgam levar à dissidência sexual e/ou de gênero; por isso, o controle e a vigilância. (TOLEDO; TEIXEIRA FILHO, 2013, p. 180)

Freitas (2009) afirma que, no âmbito escolar, um dos maiores entraves para homossexuais são os próprios alunos que, desprovidos de informação, discriminam aqueles que se comportam de maneira diferente do que está dentro do normal para eles. Devido à discriminação sofrida, a maioria dos homossexuais acaba por não possuir uma formação completa perante os traumas sofridos durante a infância ou até mesmo na adolescência.

Pode-se observar, portanto, que os problemas enfrentados por homossexuais surgem desde a descoberta da sexualidade, a revelação à família e as relações que esses possuem com o mundo - seja no âmbito escolar, social ou até mesmo profissional, que é o foco desse estudo.

\section{A população LGBTQIAP+: entendendo as diferenças}

\section{Homossexualidade}

A sigla LGBTQIAP+ é uma junção dos termos que separam cada indivíduo com orientação sexual diferente da heterossexual - ou seja, a homossexualidade. Inicia-se então por entender e identificar o contexto da homossexualidade.

Mesmo após a negação da possibilidade por associações e conselhos formados por médicos e psicólogos, uma boa parte da população acredita que a homossexualidade advém de causas biológicas ou emocionais.

Conforme Modesto (2008), a homossexualidade é uma variação da manifestação sexual, e não uma doença física ou um distúrbio psicológico. 
A homossexualidade não é uma doença física, nem é um problema psicológico. Em, 1973, a APA (Associação Brasileira de Psiquiatria) retirou a homossexualidade do seu Manual de Diagnósticos e Estatística de Distúrbios Mentais (DSM), com base em estudos, demonstrando que a homossexualidade nada mais é do que uma variação possível e legítima de manifestação do desejo sexual. No Brasil, em 1985, o Conselho Federal de medicina passou a não considerar a homossexualidade uma doença mental ou física. Em 1999, foi publicada uma resolução do Conselho Federal de Psicologia que normatizou a conduta dos psicólogos quanto à questão: “...Os psicólogos não colaborarão com eventos ou serviços que proponham tratamento e cura das homossexualidades". (MODESTO, 2008, p. 45-46)

Conforme as afirmações de Modesto (2008), é possível considerar que a homossexualidade se manifesta pela variação da atração sexual, na qual um homem pode sentir atração por outro homem e uma mulher pode sentir atração por outra mulher.

O homossexual, público alvo deste trabalho, é o ser humano que pratica a homossexualidade - ou seja, sente atração sexual por pessoas do mesmo sexo biológico.

Quando identifica a sua própria sexualidade, o homossexual tende a passar por dois desafios: a autoaceitação e o preparo para revelar ao mundo sua orientação sexual. (MODESTO, 2010).

Durante esse processo, o homossexual tem algumas reflexões quanto às escolhas que deve fazer e consequências de se revelar homossexual, tendo que avaliar a possível não aceitação da família em troca de suas felicidade e liberdade.

Conforme Modesto (2010), ainda existe a possibilidade de que, neste momento de reflexão, o homossexual conclua que nunca será feliz no caso de haver o abandono da família.

No momento da autoaceitação, o homossexual tem que lidar com duas personalidades internas, sendo uma delas sujeito e a outra antissujeito. Essas duas personalidades entram em conflito uma vez que uma reconhece a homossexualidade e busca a autoaceitação e a outra a nega. 
No desafio da autoaceitação, o ator é sincrético, no sentido de recobrir vários papéis actanciais, pois se desdobra em dois actantes, "ele", sujeito, contra "ele mesmo", antissujeito. Um deles sabe que é homossexual e tenta se aceitar; o outro não quer. Além disso o ator também é investido dos papéis actanciais de destinador manipulador e de destinador-julgador dele mesmo. (MODESTO, 2010, p. 46)

Modesto (2010) ainda afirma que a intolerância e o preconceito podem surgir do sujeito e retornar para si mesmo (pelo suicídio, por exemplo) - ou seja, no processo de reflexão sobre a autoaceitação, o preconceito pode ser no âmbito do "eu".

Segundo a autora, o desafio da revelação da homossexualidade é tão difícil quanto, ou ainda mais que, a autoaceitação - dado que o homossexual tem que assumir-se para seu meio de convívio (família, pais, trabalho, escola etc.).

Em meio a depoimentos colhidos, Modesto (2010) identifica que existe a preocupação dos homossexuais com relação aos sentimentos dos pais e mães quanto ao processo de aceitá-los, na medida em que eles mesmos já passaram pelo processo de autoaceitação que é semeIhante ao processo que os pais terão que enfrentar.

\section{Expressão de gênero/identidade de gênero, orientação se- xual e sexo biológico}

A expressão de gênero/identidade de gênero refere-se à forma como uma pessoa se sente perante as definições de masculino e feminino. Vale lembrar que nem todas as pessoas se definem meramente dentro dessas definições de gênero binário - existem pessoas que não se enquadram nessas definições, sendo chamadas de queer ou agênero (REIS, 2018) - termos explicitados ao longo deste estudo.

Orientação sexual, conforme Reis (2018), é uma tendência involuntária de cada pessoa ao sentir atração sexual por pessoas do mesmo gênero, vários gêneros ou gênero diferente do seu.

O sexo biológico refere-se ao que existe objetivamente em cada pessoa, como os cromossomos; sendo $X X$ para o sexo feminino, que possuem vagina e ovários, $\mathrm{XY}$ para o sexo masculino, que possuem pênis 
e testículos. Por fim, o intersexual, que é a combinação do masculino com o feminino. (REIS, 2018)

$\mathrm{Na}$ sigla LGBTOIAP+, cada letra explicita os diferentes tipos de orientações sexuais existentes, conforme descritos a seguir. Vale ressaltar que a intenção aqui não é de estabelecer rótulos, mas sim de auxiliar os leitores na direção do reconhecimento das diferenças e do respeito - acima de tudo.

"L" de lésbica

Oriunda do século VI a.C., essa palavra deriva da ilha de Lesbos, devida à criação do "The $L$ World" pela poeta grega Safo, que juntou uma série de garotas e escreveu poemas sobre como elas eram atraentes (DAWSON, 2015).

Atualmente, a palavra é utilizada para referir-se à

Mulher que é atraída afetiva elou sexualmente por pessoas do mesmo sexo/gênero (cis ${ }^{4}$ ou trans). Não precisam ter tido, necessariamente, experiências sexuais com outras mulheres para se identificarem como lésbicas (GÊNERO, 2009 apud REIS, p. 23).

"G" de gay

Uma palavra cujo significado em inglês é tirado do galicismo (gaiety), usado apenas para dizer que uma pessoa era descontraída, luminosa, exuberante e alegre (DAWSON, 2015). Desde os anos 1930, entretanto, o termo teve o seu significado associado à homossexualidade masculina e foi possível observar que os indivíduos assim reconhecidos acabaram por preferi-lo, estabelecendo-o já pelos idos de 1960.

Gay, então, é a

Pessoa do gênero masculino (cis ou trans) que tem desejos, práticas sexuais e/ou relacionamento afetivo-sexual com outras pessoas do gênero masculino. Não precisam ter tido,

4 Cis ou cisgênero é o indivíduo que se identifica com o sexo biológico com o qual nasceu. 
necessariamente, experiências sexuais com outras pessoas do gênero masculino para se identificarem como gays (GÊNERO, 2009, apud REIS, 2018, p. 22).

\section{"B" de bissexual}

O termo bissexual, ou simplesmente "bi", é utilizado para se referir à "pessoa que se relaciona afetiva e sexualmente com pessoas de ambos os sexos/gêneros" (GÊNERO, 2009 apud REIS, 2018, p. 21). Conforme Dawson (2015), há mal-entendidos sobre a bissexualidade. Pessoas bissexuais são incompreendidas e, muitas vezes, vistas pela sociedade como "gananciosas" pelo fato de se relacionarem com os dois gêneros.

"T" de transgênero, transexual, travesti e transformista (drag queen/king)

Notadamente há muita confusão quando se alcança o "T" da sigla. Para a maioria das pessoas, ainda não estão claras as diferenças entre transgêneros, travestis, transexuais e transformistas.

Transgênero é uma pessoa que nasceu com determinado sexo biológico, e não se identifica com o seu corpo. Um exemplo é o indivíduo que nasceu com genitália masculina, cresceu com as transformações causadas pelos hormônios masculinos, mas sua identificação é com o físico feminino. (CAMPOS, 2018)

Dentro dos transgêneros, estão inclusos transexuais e travestis. Transexual é a

Pessoa que possui uma identidade de gênero diferente do sexo designado no nascimento. As pessoas transexuais podem ser homens ou mulheres, que procuram se adequar à identidade de gênero. Algumas pessoas trans recorrem a tratamentos médicos, que vão da terapia hormonal à cirurgia de redesignação sexual. São usadas as expressões homem trans e mulher trans (CADERNO, 2017 apud REIS, 2018, p.30). 
Travesti, por sua vez, é a pessoa que

(...) nasceu com determinado sexo, ao qual foi atribuído culturalmente o gênero considerado correspondente pela sociedade, mas que passa a se identificar e construir nela mesma o gênero oposto. No caso de pessoas travestis com identidade de gênero feminina, muitas modificam seus corpos por meio de hormonioterapias, aplicações de silicone e/ou cirurgias plásticas, porém, vale ressaltar que isso não é regra para todas. (adaptado de ABGLT, 2010; CADERNO, 2017, apud REIS, 2018, p.31).

Já o transformista é o "Indivíduo que se veste com roupas do gênero oposto movido por questões artísticas" (ABGLT, 2010 apud REIS, 2018, p. 30). Quando é um homem que se veste com roupas femininas para fins artísticos, tem-se o drag queen. Quando, ao contrário, é uma mulher que se veste de homem para fins de trabalho artístico, tem-se o drag king. Essa produção é sempre "extravagante para o exercício da profissão em shows e outros eventos" (REIS, 2018, p. 28)

\section{"Q" de queer}

Queer é utilizado para identificar pessoas que não consideram a heterossexualidade como uma orientação exclusiva de sua identidade sexual. Para essas pessoas, termos como bissexual, gay ou lésbica são basicamente rótulos que não trazem consigo a amplitude das possibilidades de vivência da sexualidade (REIS, 2018).

\section{"I" de intersexual}

É um termo utilizado para identificar pessoas que não nasceram com um padrão de cromossomos que podem ser classificados como masculinos ou femininos. Deve-se evitar o termo hermafrodita.

Nesses casos, é comum que médicos indiquem um tratamento hormonal e até mesmo cirurgias, a fim de tornar estas pessoas parte de um único gênero, geralmente entre os primeiros 24 meses de vida. Pode ocorrer futuramente que a pessoa submetida a tais procedimentos não se identifique com o gênero designado e opte por outra orientação sexual. (SANTOS; ARAÚJO, 2004). 
" $A$ " de agênero e assexual

Agênero é o termo usado para definir aqueles que não se sentem pertencentes a nenhum gênero. Assexual se refere àqueles que não possuem desejo sexual - seja pelo sexo/gênero oposto ou igual ao seu.

"P" de pansexual

O prefixo "pan", do grego, significa "tudo" - partindo desse princípio, pansexual é o termo designado àqueles que sentem atração por todas as pessoas, independentemente da orientação sexual, gênero e afins.

Há vários programas de inclusão existentes que visam oferecer suporte a esse público quanto à tentativa de ingresso no mercado de trabalho. Entre os principais, destacam-se o projeto TransEmpregos, o programa Transcidadania (antigo POT - Programa Operação Trabalho) e os projetos sociais English to Trans-form, Casa 1 e PreparaNem-CasaNem.

\section{Procedimentos metodológicos}

O estudo foi elaborado utilizando o critério proposto por Vergara (2016) para definição metodológica. Quanto aos fins, esta pesquisa é descritiva, pois se propõe a descrever o fenômeno de inclusão de transexuais e transgêneros no mercado de trabalho analisando os fatores influentes nesse processo. Quanto aos meios, trata-se de uma pesquisa de campo por se basear em relatos do público LGBTOIAP+ através da análise do conteúdo de entrevistas com cinco alunos dos cursos regulares da Universidade pesquisada, definidas por acesso e tipificação (transgênero e transexuais) para coleta de informações sobre experiências que tiveram com o mercado de trabalho.

Para analisar os dados obtidos a partir das entrevistas, foi utilizado o método de análise de conteúdo definido por Bardin (2011). Segundo o autor (2011, p. 44 apud GOMES, 2016 p. 99), a análise de conteúdo trata-se de "[...] um conjunto de técnicas para analisar as comunicações, utilizando-se de procedimentos sistemáticos e objetivos de descrição dos conteúdos das mensagens".

A técnica utilizada foi a de análise de conteúdo categorial, que na prática "funciona por operações de desmembramento do texto 
em unidades, em categorias segundo reagrupamentos analógicos". (BARDIN, 2011, p. 201)

O Quadro 1 descreve de forma sucinta as etapas seguidas para que o cumprimento da técnica fosse efetuada:

Quadro 1. Etapas da análise de conteúdo

\begin{tabular}{|l|l|}
\hline \multicolumn{1}{|c|}{ FASE } & \multicolumn{1}{c|}{ DESCRIÇÃO } \\
\hline Preanálise & $\begin{array}{l}\text { Fase de organização, período de intuições. Tem por objetivo tornar } \\
\text { operacionais e sistematizar as ideias iniciais. Etapas: escolha dos } \\
\text { documentos, preparação do material e leitura flutuante. }\end{array}$ \\
\hline Codificação & $\begin{array}{l}\text { Corresponde a uma transformação - efetuada segundo regras } \\
\text { precisas - dos dados brutos do texto (por recorte, agregação e } \\
\text { enumeração) que representa o conteúdo ou a sua expressão; } \\
\text { esclarece características do texto que podem servir de índices. }\end{array}$ \\
\hline Categorização & $\begin{array}{l}\text { É uma operação de classificação de elementos constitutivos de um } \\
\text { conjunto por diferenciação e por reagrupamento (analogia) com } \\
\text { os critérios estabelecidos. As categorias são rubricas ou classes } \\
\text { suas características comuns, sob um título genérico. O critério } \\
\text { de categorização pode ser semântico (temas), sintático (verbos/ } \\
\text { adjetivos), léxico (sentido) e expressivo (perturbações da linguagem). }\end{array}$ \\
\hline Inferência & $\begin{array}{l}\text { A intenção da análise de conteúdo é a inferência (deduções } \\
\text { lógicas) de conhecimentos relativos às condições de produção } \\
\text { (ou recepção) que recorre a indicadores (quantitativos ou não). }\end{array}$ \\
\hline
\end{tabular}

Fonte: GOMES, 2016, adaptado de BARDIN, 2011.

\section{Preanálise}

Para realizar a pré-análise foi utilizada a transcrição do áudio das entrevistas realizadas. A fim de estabelecer um contato mais próximo, foi efetuada uma leitura flutuante do conteúdo transcrito, permitindo a coleta de impressões úteis às etapas seguintes. (BARDIN, 2011, apud GOMES, 2016)

\section{Codificação}

Para realizar o processo de codificação foram utilizados como base os objetivos específicos da pesquisa para a definição dos temas a serem analisados. 
Fazer uma análise temática consiste em descobrir os "núcleos de sentido" que compõem a comunicação e cuja presença ou frequência de aparição podem significar alguma coisa para o objetivo analítico escolhido. (BARDIN, 2011, p. 135)

\section{Objetivo específico 1}

Caracterizar a população LGBTQIAP+, na qual estão inseridos transexuais e transgêneros, destacando suas principais diferenças.

\section{Tema de análise}

Identidade de gênero

Figura 2. Definição de tema de análise: identidade de gênero Fonte: Elaborado pelas autoras

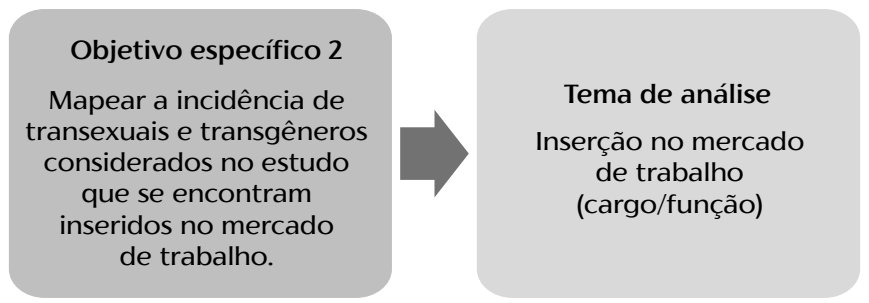

Figura 3. Definição de tema de análise: inserção no mercado de trabalho (cargo/função)

Fonte: Elaborado pelas autoras

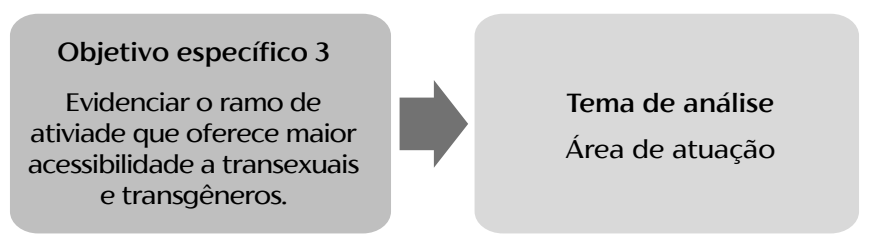

Figura 4. Definição de tema de análise: área de atuação

Fonte: Elaborado pelas autoras

Definidos os temas de análise, sucede-se a etapa de categorização das entrevistas realizadas. 


\section{Categorização}

Pode-se definir a categorização como: “[...] uma operação de classificação de elementos constitutivos de um conjunto por diferenciação e, em seguida, por reagrupamento segundo o gênero (analogia), com os critérios previamente definidos." (BARDIN, 2011, p. 147)

A categorização do presente estudo foi realizada obedecendo o critério semântico, que utiliza categorias temáticas uma vez que os temas e subtemas já estão indicados no momento de estruturação das entrevistas.

Seguindo o modelo de categorização por caixa, o processo possibilitou organizar as categorias. Em seguida, como apoio às categorias, estão os indicadores/unidades de registro. Para um melhor entendimento dos indicadores/unidades de registro, seguem as unidades de contexto, que são indicações para fazer referência ao contexto.

Feitas essas considerações, possibilita-se a criação de uma matriz de análise de conteúdo de forma esquematizada, o que subsidiou a interpretação dos dados com base nas inferências realizadas. A apresentação da matriz ocorre de forma dividida, na qual cada tema de análise possui um quadro.

Quadro 2. Matriz de análise de conteúdo

\begin{tabular}{|c|c|c|c|}
\hline Tema & Categorias & $\begin{array}{c}\text { Indicadores/ } \\
\text { Unidades de registro }\end{array}$ & Unidades de contexto \\
\hline \multirow{2}{*}{ 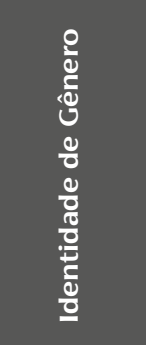 } & $\begin{array}{l}\text { Homem } \\
\text { Trans }\end{array}$ & $\begin{array}{l}\text { "Eu sou", "Eu me } \\
\text { considero", "Me } \\
\text { considero", "Eu me } \\
\text { identifico", "Eu me vejo". }\end{array}$ & $\begin{array}{l}\text { "Me considero um homem } \\
\text { trans", "sou um homem } \\
\text { trans", "eu me considero trans } \\
\text { masculino", "me ver como uma } \\
\text { pessoa trans, homem trans". }\end{array}$ \\
\hline & $\begin{array}{l}\text { Mulher } \\
\text { Trans }\end{array}$ & $\begin{array}{l}\text { "Eu sou", "Eu me } \\
\text { considero", "Me } \\
\text { considero", "Eu me } \\
\text { identifico", "Eu me vejo". }\end{array}$ & $\begin{array}{l}\text { "Eu me considero uma } \\
\text { mulher trans". }\end{array}$ \\
\hline 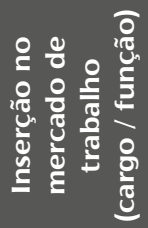 & Empregado & $\begin{array}{l}\text { "Eu atuo", "eu trabalho", } \\
\text { "eu sou", "meu cargo", } \\
\text { "estagiário". }\end{array}$ & $\begin{array}{l}\text { "eu sou estagiário de } \\
\text { projetos", "eu trabalho } \\
\text { atualmente como modelo", } \\
\text { "estagiário", "eu sou gerente } \\
\text { de redes sociais", "sou artista } \\
\text { independente". }\end{array}$ \\
\hline
\end{tabular}

continua na próxima página... 
Quadro 2. Matriz de análise de conteúdo

\begin{tabular}{|c|c|c|c|}
\hline Tema & Categorias & $\begin{array}{c}\text { Indicadores/ } \\
\text { Unidades de registro }\end{array}$ & Unidades de contexto \\
\hline \multirow{4}{*}{ 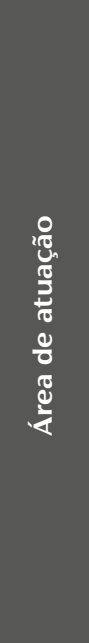 } & Área de TI & $\begin{array}{l}\text { "eu atuo na área", } \\
\text { "eu atuo", "eu estou", } \\
\text { "eu trabalho". }\end{array}$ & $\begin{array}{l}\text { "Eu estou na área de TI, } \\
\text { área de projetos". }\end{array}$ \\
\hline & $\begin{array}{l}\text { Meio } \\
\text { Artístico }\end{array}$ & $\begin{array}{l}\text { "eu atuo na área", } \\
\text { "eu atuo", "eu estou", } \\
\text { "eu trabalho". }\end{array}$ & "Meio artístico". \\
\hline & $\begin{array}{l}\text { Área } \\
\text { Comercial }\end{array}$ & $\begin{array}{l}\text { "eu atuo na área", } \\
\text { "eu atuo", "eu estou", } \\
\text { "eu trabalho". }\end{array}$ & $\begin{array}{l}\text { "Eu estou atuando na área } \\
\text { comercial". }\end{array}$ \\
\hline & $\begin{array}{l}\text { Área de } \\
\text { Publicidade }\end{array}$ & $\begin{array}{l}\text { "eu atuo na área", } \\
\text { "eu atuo", "eu estou", } \\
\text { "eu trabalho". }\end{array}$ & "Publicidade". \\
\hline
\end{tabular}

Fonte: Elaborado pelas autoras

\section{Inferências}

Inferência, segundo Bardin (2011, p. 44), é “[...] um conjunto de técnicas de análise das comunicações que utiliza procedimentos sistemáticos e objetivos de descrição no conteúdo das mensagens".

A seguir, são apresentadas a análise e a interpretação dos dados da pesquisa, a saber: o conteúdo das respostas das entrevistas realizadas.

\section{Resultados da pesquisa}

Baseando-se na matriz de análise de conteúdo na qual foram apresentadas considerações acerca dos temas de análise mapeados com objetivo de apoiar as ponderações anteriormente realizadas, a seguir estão, de forma complementar, os trechos dos depoimentos colhidos que foram analisados e transcritos. 
Identidade de gênero

Acerca da identidade de gênero, apesar de o estudo considerar transexuais e transgêneros, todos os entrevistados se identificaram como transexuais. Pôde-se observar que, embora a definição para homens ou mulheres transexuais seja a mesma, cujo nome de identificação utilizado é transexual, muitos se identificam como homem trans, mulher trans ou ainda transmasculino. É possível verificar que o significado de ser transexual varia de entrevistado a entrevistado conforme os depoimentos a seguir, coletados durante a pesquisa:

Me considero um homem trans porque sim, independente da transição ou não, é só você considerar que não está de acordo com a sua genitália que você é trans. (entrevistado 1, homem transexual)

Eu me considero uma mulher trans, e não tem um porquê. A gente, quando a gente entende o que a gente é, e eu sempre soube o que eu era, só não entendia o termo, né [...]. (entrevistado 2, mulher transexual)

Sou homem trans porque eu me entendo como homem apesar de ter nascido no corpo de menina, e eu me identifico completamente como masculino. (entrevistado 3, homem transexual)

Então, eu me considero transmasculino; a gente usa a palavra "boyceta" também, que seria de certa forma, assim, não exatamente igual, mas uma relação parecida com mulheres trans e travestis, os homens trans e os boycetas né, tipo assim. (entrevistado 4, homem transexual)

\section{Inserção no mercado de trabalho (cargo/função)}

Quanto à inserção no mercado de trabalho (cargo/função), foi possível observar que quatro dos cinco entrevistados encontram-se no mercado de trabalho atuando de maneira formal ou como freelancer de forma independente. Vale ressaltar a atuação de dois dos entrevistados em áreas que 
notadamente são mais acessíveis para esse público (artes/moda e cultura, entrevistados 2 e 4, respectivamente). A seguir encontram-se os depoimentos nos quais os entrevistados/as declaram estar trabalhando:

Eu sou estagiário de projetos. (entrevistado 1)

Eu trabalho atualmente como modelo [...]. (entrevistado 2)

Estagiário. (entrevistado 3)

[...] sou artista independente. (entrevistado 4)

Gerente de redes sociais. (entrevistado 5)

\section{Área de Atuação}

No que se refere à área de atuação, pôde-se observar que os entrevistados se encontram em áreas diferentes. Nos trechos dos depoimentos a seguir estão as áreas de atuação dos entrevistados empregados. Apesar da diversidade, observa-se, entre os entrevistados, que há a prevalência do meio artístico. Historicamente, esse meio concentra visões de mundo e de humanidade mais libertárias, menos restritas às convenções sociais impostas.

Estou na área de TI, área de projetos. (entrevistado 1)

Eu trabalho atualmente como modelo, né, porque eu fiz artes cênicas e aí foi abrindo portas... O meio artístico sempre abre portas [...]. (entrevistado 2)

Área Comercial. (entrevistado 3)

[...] sou artista independente. (entrevistado 4)

Publicidade. (entrevistado 5) 


\section{Considerações finais}

Considerando o objetivo principal, o presente estudo buscou identificar os fatores que interferem na inserção de jovens transexuais e transgêneros no mercado de trabalho - esses descritos ao longo do estudo e corroborado pelas entrevistas realizadas. Para chegar ao objetivo principal, outras ações foram definidas e atendidas, a saber: foi realizada a caracterização da população LGBTQIAP+, na qual estão inseridos os transexuais e transgêneros, destacando suas principais diferenças; o mapeamento dos indivíduos inseridos no mercado de trabalho, bem como o ramo de atividade mais acessível a esse público e a indicação de alguns programas e projetos sociais que se destacam pelo esforço e apoio na inserção desse público no mercado de trabalho.

Pode-se concluir que o presente estudo traz como contribuição informações relevantes acerca dos fatores influentes quanto à questão de diversidade no mercado de trabalho - mais especificamente do público trans, uma vez que, através dos depoimentos e análises realizadas, identifica-se que ainda é muito difícil e pequena a entrada de pessoas trans no mercado de trabalho - menor ainda para mulheres transexuais (homens que se tornaram e se identificam como mulheres).

Corroborando a informação acima descrita, dados da Associação Nacional de Travestis e Transexuais (2018) informam que 90\% da população de travestis e mulheres transexuais encontram-se envolvidas com prostituição devido à falta de oportunidades no mercado de trabalho.

Uma vez que este estudo possui dados qualitativos, sugere-se a realização de pesquisas quantitativas com a finalidade de verificar a incidência das inferências aqui feitas, como, por exemplo, a área de atuação que oferece maiores oportunidades de trabalho ao público trans.

\section{Referências}

ASSOCIAÇÃO NACIONAL DE TRAVESTIS E TRANSEXUAIS. Mapa dos assassinatos de travestis e transexuais em 2017. Brasília, 29 jan. 2018.

Disponível em: https://bit.ly/3boLcoX. Acesso em: 25 nov. 2019. BARDIN, Laurence. Análise de conteúdo. São Paulo: Edições 70, 2011. 
BARROS, Isa Correia; SANI, Ana; SANTOS, Luís. "É igual mas é diferente": gênero e violência na intimidade entre pessoas do mesmo sexo. Análise Social, Lisboa, v. 1, n. 230, p. 106-130, jan./mar. 2019.

BEAUVOIR, Simone de. O segundo sexo. 2. ed. Rio de Janeiro: Nova Fronteira, 2009.

BORIN, Thaísa Belloube. Violência doméstica contra a mulher: percepções sobre violência em mulheres agredidas. 2007. Dissertação (Mestrado em Psicologia) - Faculdade de Filosofia, Ciências e Letras de Ribeirão Preto, Universidade de São Paulo, Ribeirão Preto, 2008.

CABRAL, Fernanda Araujo. Investigação do potencial de desenvolvimento do preconceito em crianças pequenas. 2016. Tese (Doutorado em Psicologia Escolar e do Desenvolvimento Humano) Instituto de Psicologia, Universidade de São Paulo, São Paulo, 2016.

CAMPOS, Lorraine Vilela. Cisgênero e transgênero. Brasil Escola, Goiânia, 26 set. 2018. Disponível em: https://bit.ly/3kh0YG8. Acesso em 15 out. 2020.

CROCHÍk, José Leon. Preconceito, indivíduo e cultura. 3. ed. São Paulo: Casa do Psicólogo, 2006.

CUSTÓDIO SOBRINHO, Juliano. Sobre um tempo de incertezas: o processo da abolição e os significados da liberdade em Minas Gerais (1880-1888). 2014. Tese (Doutorado em História Social) - Faculdade de Filosofia, Letras e Ciências Humanas, Universidade de São Paulo, São Paulo, 2015.

DAWSON, James. Este livro é gay: e hétero, e bi, e trans.... São Paulo: WMF Martins Fontes, 2015.

DOMINGUES, Petrônio José. Uma história não contada: negro, racismo e branqueamento em São Paulo no pós-abolição. São Paulo: Senac, 2004.

FREITAS, Maria Alcina Ramos de. Purpurina na terra do cangaço: refletindo a homossexualidade na escola. 2009. Dissertação (Mestrado em Educação Brasileira) - Centro de Educação, Universidade Federal de Alagoas, Maceió, 2009.

GOMES, Dione Fagundes Nunes. Construção da identidade profissional em jovens universitários bolsistas: um estudo a partir dos valores e das definições de âncoras de carreira. 2016. Tese (Doutorado em Administração) - Programa de Estudos Pós-Graduados em 
Administração, Pontifícia Universidade Católica de São Paulo, São Paulo, 2016.

INSTITUTO BRASILEIRO DE GEOGRAFIA E ESTATísTICA. Pesquisa Nacional por Amostra de Domicílios Contínua - PNAD Contínua. Disponível em: https://bit.ly/20J4DiC. Acesso em: 25 nov. 2019. MALUF, Adriana Caldas do Rego Freitas Dabus. Novas modalidades de família na pós-modernidade. 2010. Tese (Doutorado em Direito Civil) Faculdade de Direito, Universidade de São Paulo, São Paulo, 2010.

MISKOLCI, Richard. A teoria queer e a sociologia: o desafio de uma analítica da normalização. Sociologias, Porto Alegre, a. 11, n. 21, p. 150-182, jan./jun. 2009.

MODESTO, Edith. Homossexualidade, preconceito e intolerância: Análise semiótica de depoimentos. 2010. Tese (Doutorado em Semiótica e Linguística Geral) - Faculdade de Filosofia, Letras e Ciências Humanas, Universidade de São Paulo, São Paulo, 2010.

MODESTO, Edith. Mãe sempre sabe? Mitos e verdades sobre pais e seus filhos homossexuais. São Paulo: Record, 2008.

NUNES, Sylvia da Silveira. Racismo contra negros: um estudo sobre o preconceito sutil. 2010. Tese (Doutorado em Psicologia Escolar e do Desenvolvimento Humano) - Instituto de Psicologia, Universidade de São Paulo, São Paulo, 2010.

REIS, Toni (org.). Manual de Comunicação LGBTI+. 2. ed. Curitiba: Aliança Nacional LGBTI/GayLatino, 2018. Disponível em: https://bit.ly/3bfrBHR. Acesso em: 25 nov. 2019.

SANTOS, Moara de Medeiros Rocha; ARAÚJO, Tereza Cristina Cavalcanti Ferreira de. Intersexo: o desafio da construção de identidade de gênero. Revista da SBPH, Rio de Janeiro, v. 7, n. 1, p. 17-28, jan./jun. 2004.

SAGIM, Mírian Botelho. Estudo sobre relatos de violência contra a mulher segundo denúncias registradas em delegacia especializada na cidade de Goiânia - Goiás nos anos de 1999 e 2000. 2004. Dissertação (Mestrado em Psicologia) - Faculdade de Filosofia, Ciências e Letras de Ribeirão Preto, Universidade de São Paulo, Ribeirão Preto, 2004.

SOBROSA, Gênesis Marimar Rodrigues; CAMERIN, Cassiano; SANTOS, Anelise Schaurich dos; DIAS, Ana Cristina Garcia. Considerações 
acerca da inserção profissional de jovens do ensino médio. Mudanças em Psicologia da Saúde, São Bernardo do Campo, v. 20, n. 1-2, p. 41-49, jan./dez. 2012.

SOLIVA, Thiago Barcelos; SILVA JUNIOR, João Batista da. Entre revelar e esconder: pais e filhos em face da descoberta da homossexualidade. Sexualidad, Salud y Sociedad, Rio de Janeiro, n. 17, p. 124-148, maio/ago. 2014.

SOUZA, Rosangela Conceição de. Letramento crítico: um auto-olhar sobre os preconceitos das "minorias sociais" em busca de uma prática libertadora. 2012. Tese (Doutorado em Estudos Linguísticos e Literários em Inglês) - Faculdade de Filosofia, Letras e Ciências Humanas, Universidade de São Paulo, São Paulo, 2012.

TOLEDO, Lívia Gonsalves; TEIXEIRA FILHO, Fernando Silva. Homofobia Familiar: abrindo o armário 'entre quatro paredes'. Arquivos Brasileiros de Psicologia, Rio de Janeiro, v. 65, n. 3, p. 376-391, jan./dez. 2013.

VERGARA, Sylvia Constant. Projetos e relatórios de pesquisa em administração. 16. ed. São Paulo: Atlas, 2016. 



\title{
Desigualdade de gênero nas agências bancárias: percepção de mulheres durante seu processo de construção de carreira
}

\author{
Caio Cesar Gonçalves Pires \\ Crisomar Lobo de Souza
}

\begin{abstract}
Resumo
Este trabalho tem como objetivo analisar a percepção das mulheres que trabaIham em agências bancárias sobre a desigualdade de gênero em bancos. Foram realizadas entrevistas com funcionárias de diferentes bancos comerciais para entender a percepção e vivência dessas mulheres acerca do tema. Percebeu-se que algumas desigualdades de gênero presentes no mercado de trabalho também são sofridas por essas mulheres nos bancos, como assédio, dificuldade de conciliação entre vida pessoal e profissional, ambiente machista e objetificação do corpo feminino. Porém, por outro lado, algumas questões sofridas por mulheres no mercado de trabalho não são sentidas por mulheres bancárias, como diferença salarial e possibilidade de promoção, sendo essas consideradas iguais para ambos os gêneros. Por fim, este trabalho visa trazer contribuições para o campo de estudo da Administração, para as organizações e para a sociedade, dividindo informações e fatos que ocorrem no universo estudado universo, que é tão relevante e essencial para uma sociedade igualitária.
\end{abstract}

Palavras-chave: Desigualdade de gênero. Mercado de trabalho. Banco. 


\section{Introdução}

Podemos caracterizar a diversidade como uma mistura de pessoas de diferentes identidades, podendo ser de gênero, cor, orientação sexual, religião, entre outros, que interagem no mesmo sistema social, como no trabalho, na família, na universidade, em cidades, países e em vários outros grupos. Nesses sistemas, existem as maiorias e minorias, sendo que as primeiras têm mais acesso a recursos e poder em relação aos demais, criando uma vantagem que as coloca em relação privilegiada dentro do grupo, gerando com isso a desigualdade. Sendo assim, podemos estudar a diversidade em diferentes âmbitos, como o social, organizacional, em determinado grupo e de maneira individual (FLEURY, 2000). O objetivo aqui é discutir e entender a desigualdade de gênero e o papel da mulher nos diferentes grupos de que ela faz parte, com enfoque nas relações de trabalho.

Podemos definir de forma simples as relações de trabalho como um ambiente onde há troca entre trabalhadores e empregadores por intermédio do trabalho realizado em troca de pagamento de salário, sendo este a recompensa pela prestação de serviço (OLIVEIRA; PICCININI, 2011). Segundo Cappelle, Melo e Souza (2013), nesse contexto estão tanto homens quanto mulheres, porém as diferenças estão hierarquizadas e colocam o homem em uma situação privilegiada em relação a mulher. Essa situação pode ser caracterizada como discriminação direta quando há normas que favorecem o tratamento desigual, ou indireta quando critérios aparentemente neutros produzem resultados diferentes entre pessoas de gêneros distintos.

A mulher teve seu papel dentro das famílias inicialmente como responsável pelo cuidado doméstico e familiar, setor caracterizado como privado, e o homem como provedor de recursos, sendo este caracterizado como setor público (HOFFMANN; LEONE, 2009). Essa separação e hierarquização entre as esferas pública e privada colocou o homem como principal e único provedor e a mulher como responsável ou exclusiva da esfera privada (ORGANIZAÇÃO INTERNACIONAL DO TRABALHO, 2010).

Na década de 1970, a mulher começou ter representatividade no que diz respeito ao trabalho, mudando a maneira como era vista na sociedade. Isso aconteceu pela expansão da economia e juntamente 
com o processo de industrialização e urbanização da época. O perfil daquela mulher em sua maioria era jovem, solteira, com pouca escolaridade e em empregos de baixo grau hierárquico e instrução. Esse perfil foi evoluindo nas décadas seguintes e, em 1990, a mulher já tinha um papel relevante na sociedade em relação ao trabalho - já era casada, com maior grau de instrução e tinha representatividade econômica dentro das famílias -, mas suas ocupações eram menos valorizadas, o mercado continuava segmentado por gênero e os homens detinham as posições de prestígio (HOFFMANN; LEONE, 2009).

Mesmo com as mulheres conseguindo espaço dentro das empresas, existe até hoje questões a serem discutidas. Há uma necessidade constante de qualificação profissional superior à do homem e a mulher ainda é responsável pelas tarefas do lar. A conquista de novos papéis na sociedade não fez desaparecer antigas funções domésticas socialmente atribuídas a elas e esse acúmulo pode deteriorar sua saúde física e emocional, sentindo que não conseguem desempenhar bem nenhum desses papéis (AMARAL, 2012).

Temos que levar em conta que o emprego torna-se fonte de prazer e reconhecimento social e gera experiências não vivenciadas no ambiente doméstico. A quebra de paradigmas e a conquista de valores de gênero igualitários dão a possibilidade necessária para a mulher desenvolver todo o seu potencial profissional (AMARAL, 2012). Diante dessa perspectiva, há uma inferiorização na maneira como o trabalho da mulher é visto, com ela sendo considerada um elemento secundário das possibilidades reais que pode atingir e de seu projeto de vida (ORGANIZAÇÃO INTERNACIONAL DO TRABALHO, 2010).

No setor bancário ainda existem grandes desigualdades de gênero, principalmente na relação hierárquica das organizações. No banco Itaú, em 2016, as mulheres ocupavam $12,1 \%$ das vagas de diretoria e $24,5 \%$ de superintendência; em 2018, esses números aumentaram para 13,9\% e 27,3\%, respectivamente. Podemos observar que existe um movimento de valorização do trabalho e da capacidade da mulher, porém ainda está longe de alcançar um padrão de igualdade. O trabalho é uma grande fonte de autonomia para as pessoas, além de fazer parte do contexto social, estando ligado à autoestima, meios de sobrevivência, capacidade de adquirir bens de consumo, concepção de identidade e obtenção de elos sociais (FONTOURA; 
GONZALEZ, 2009). Mas a discriminação de gênero cria um ambiente desigual e coloca a mulher em uma posição inferior à do homem, ficando difícil a permanência do ser feminino no meio público de produção com condições para o seu desenvolvimento. Cabe salientar que mulheres e negros, na sua totalidade, têm a maior representatividade da força de trabalho no Brasil e, em contraponto, possuem os piores indicadores (ORGANIZAÇÃO INTERNACIONAL DO TRABALHO, 2010).

Apesar de parecer que a desigualdade de gêneros está desaparecendo e que as mulheres estão tendo os mesmo direitos que os homens, tendo em vista as grandes conquistas obtidas por elas nas últimas décadas, a realidade é que as relações de desigualdade estão sendo naturalizadas através de reafirmações que colocam esse comportamento como comum em várias sociedades, ou mesmo expondo-o de maneira mais sutil aos olhos da sociedade (CAPPELLE; MELO; SOUZA, 2004; CALÁS; SMIRCICH, 2010).

A conscientização e questionamentos acerca do tema tornam-se importantes mecanismos de resistência, essenciais para a construção de mudanças nas relações de gênero (CAPPELLE; MELO; SOUZA, 2004). Dessa maneira, com a construção de uma base sólida de conhecimentos, tornam-se mais eficientes as medidas para a construção de uma sociedade igualitária (ORGANIZAÇÃO INTERNACIONAL DO TRABALHO, 2010). Há necessidade de maior compreensão acerca do tema, visto que as mulheres estão progressivamente alcançando espaço e visibilidade nas relações de trabalho (LEMOS; MELLO; GUIMARÃES, 2014).

Tais publicações e reflexões incluem, além dos aspectos de gênero, um aprofundamento e maior produção teórica que evidenciem e analisem criticamente tais desigualdades. Isso está ligado diretamente à perpetuidade e glória das organizações, estando sujeito, assim, ao reconhecimento das pluralidades existentes em cada indivíduo e à gestão da diversidade, e como consequência desse processo está o esgotamento das desigualdades de gênero (CAPPELLE; MELO; SOUZA, 2004).

É visível a falta de pesquisas que relacionem o setor bancário com as desigualdades de gênero existentes no campo de trabalhista e no meio que circunda as organizações do setor, o que requer mais produções com tal temática, visto a importância do trabalho e da procura pela igualdade entre os gêneros na sociedade e para as mulheres. 
Percebe-se que a desigualdade de gênero em ambientes que envolvem relações de trabalho é bastante abordada no campo científico. No entanto, há carência de estudos que discutam essa relação dentro das empresas (SOUZA; AMORIM; SILVA, 2011). Para contribuir com essa discussão, este trabalho visa responder a seguinte pergunta: como as mulheres em agências bancárias percebem a desigualdade de gênero durante seu processo de construção de carreira?

\section{Referêncial teórico}

\section{Divisões de gênero desiguais}

O ser humano é extremamente diverso em suas características pessoais, mas não apenas nisso: torna-se ainda mais diverso na maneira como cada pessoa enxerga a si mesma e ao próximo. Com essa percepção do próximo e de nós mesmos, edificamos o conceito de divisão social, que pode ocorrer por diferentes causas: padronizações das pessoas, perspectivas presentes e futuras sobre uma sociedade e outro mecanismos. Entre as características gerais das divisões sociais, podemos perceber a existência de culturas perpetuadas por doutrinas reinantes, organizações sociais e interações pessoais - grupos convergentes que contrastam dos demais membros de uma sociedade e que têm acesso discrepante a recursos geram distintas chances e possibilidades de vida. Com mecanismos complexos e ocultos, as divisões sociais que envolvem os grupos regulam e distribuem os recursos disponíveis (SANTOS, 2010).

Dentro desse meio de relações desiguais se estabelece a desigualdade de gênero, que de forma geral se limita a tentar justificar a superioridade física e mental do homem em relação a mulher. As visões a respeito do tema fecharam-se em questões teóricas de caráter biológico e de fenômenos culturais.

A primeira sustenta-se nas diferenças físicas entre os gêneros com foco nas funções reprodutivas, questionando a capacidade racional da mulher em comparação à do homem. Elas são vistas como tendo maior afetividade, o que restringiria suas reais habilidades. Assim, suas atividades são limitadas ao setor privado, como cuidar dos afazeres da casa 
e da educação dos filhos, enquanto o homem, por supostamente possuir maior capacidade de raciocínio, fica responsável pelo setor público, como trabalhar e garantir o sustento da família (HOFFMANN; LEONE, 2009). Por conta do menor grau de racionalidade, a mulher seria incapaz de tomar decisões relevantes, ficando esse papel submetido ao homem, mas seria qualificada para a realização de atividades simples e sem grandes obrigações. Nesse espectro, a mulher torna-se dependente do outro gênero para ter condições favoráveis de vida (GUIMARÃES, 2005).

A segunda tem seu histórico na maioria das sociedades humanas que apresentam desenvolvimento técnico reduzido. Nessas comunidades, constata-se que bens materiais e mulheres são apenas instrumentos de troca entre chefes, situação relatada entre povos proto-históricos. Nesse ambiente, a mulher não tem possibilidade de ascensão e muito menos é vista como um ser humano com os mesmos direitos que os homens (GUIMARÃES, 2005).

Dessa maneira, a questão de gênero é colocada para caracterizar as relações sociais entre os gêneros repudiando justificativas biológicas, e indica um dominador comum para diferentes formas de subordinação, sendo também um apontamento das construções sociais acerca dos papéis inerentes aos homens e às mulheres (SCOTT, 1990). Cabe reconhecer que o sexo é determinado biologicamente, enquanto o gênero é desenvolvido socialmente (CALÁS; SMIRCICH, 2010).

Portanto, fundamentações biológicas que atribuem superioridade ao homem em relação à mulher contribuem para a opressão e exploração, tornando desiguais essas relações e garantindo a manutenção da dominância do homem sobre a mulher (AMARAL, 2012). Assim, não é mais aceitável que as distinções de sexo continuem a conduzir às desigualdades de gênero, já que esse modelo antiquado gera um desequilíbrio evidente da participação dos homens e das mulheres na esfera pública e na esfera privada (COMISSÃO PARA A IGUALDADE NO TRABALHO E NO EMPREGO, 2003; ZAULI; ROCHA; SALES, 2013).

A relevância da equivalência entre os gêneros para as mulheres torna-se essencial para que haja melhorias em suas vidas, mas não somente em aspectos particulares: também para que consigam superar concepções, mecanismos e ações institucionais que continuam colocando-as em posição secundária na sociedade, no trabalho e em outros âmbitos 
dos quais venham a fazer parte. A superação de determinados regimentos é complexa, pois encontra-se em esferas de disputa cultural e política e está sujeita a avanços e retrocessos. Para haver mudanças, há necessidade de compromisso político, criação de mecanismos de controle social, participação popular e capacidade de diálogo e interlocução (ORGANIZAÇÃO INTERNACIONAL DO TRABALHO, 2010).

\section{Trabalho e relações de gênero}

No sentido tradicional, o ambiente em que ocorrem relações de trabalho é visto como um local onde há relações fundamentais entre empregadores e trabalhadores, sendo o salário a condição necessária para que o indivíduo prestador do serviço exerça a atividade que o outro solicita e o trabalho, o produto vendido nessa relação (OLIVEIRA; PICCININI, 2011).

Para que haja um desempenho bom da economia, existe a necessidade de que os níveis de emprego e desemprego estejam controlados e que esse setor esteja em bom funcionamento em níveis aceitáveis para que a sociedade cresça (OLIVEIRA; PICCININI, 2011). A partir da concepção de que esse ambiente é formado por ambos os gêneros, nele tratados diferentemente, mostra-se então o confrontamento com questões de gênero (ORGANIZAÇÃO INTERNACIONAL DO TRABALHO, 2010).

Diante do exposto, cabe destacar a posição da ONU Mulheres Brasil sobre o que é gênero:

Refere-se ao conjunto de características sociais e culturais atribuídas às pessoas, geralmente em função do seu sexo. Enquanto o sexo biológico é determinado por características genéticas e anatômicas, o gêneroé uma identidade adquirida que é aprendida, muda ao longo do tempo e varia amplamente dentro e entre as culturas. Trata-se dos comportamentos, valores e atitudes que a sociedade define como sendo próprios de homens ou de mulheres. Enquanto as diferenças de sexo são biológicas, as de gênero são culturais e dinâmicas, podendo se transformar de acordo com o desenvolvimento específico de cada sociedade. Sua principal característica está 
na mutabilidade, isto é, na possibilidade de mudança na relação entre homens e mulheres através do tempo. Predominantemente, a interpretação de gênero é bipolar (feminino/masculino) e hierárquica (o masculino mais valorizado do que o feminino). Quando se discute essa questão, pretende-se debater e transformar a construção social e cultural das relações de gênero, no sentido de pluralizá-las e democratizá-las, eliminando discriminações baseadas em dicotomias e hierarquias estereotipantes. Por outro lado, o enfoque de gênero recoloca a formulação de problemas e soluções, pois envolve mudanças de posicionamento e comportamento de homens e mulheres, na procura da construção de sociedades mais justas (redistribuição de responsabilidades e oportunidades). (ONU MULHERES BRASIL, 2017, p. 25)

Nesse sentido, faz-se necessária a citação dos chamados estereótipos de gênero, que são suposições e personificações generalistas, enaltecidas e disseminadas pela sociedade, sobre padrões normalizados de comportamento das pessoas. Estão relacionados ao julgamento e à determinação de normas sobre o que os gêneros devem ser, ligada a traços de gênero, e fazer, ligada a papéis de gênero. Esses traços e papéis estão associados e são correntemente hierarquizados, com atribuições de menor valor social aos examinados como femininos. Portanto, estereótipos de gênero exprimem-se através de um sustentáculo de preconceitos (COMISSÃO PARA A IGUALDADE NO TRABALHO E NO EMPREGO, 2003; ZAULI; ROCHA; SALES, 2013).

Dessa forma, associar gênero e trabalho é essencial para perceber que as relações desempenham um papel estratificado nesse setor. Abranger a perspectiva de gênero nos estudos acerca do trabalho ajuda a conhecer as características desse espaço, tendo como base que o gênero pode mostrar informações importantes a respeito do funcionamento das organizações (CAPPELLE; MELO; SOUZA, 2013).

\section{Entrada da mulher nas empresas}

A sociedade brasileira teve como alicerce o patriarcado, sustentado como uma cultura de submissão de todos os membros da comunidade à figura do homem heterossexual e branco, sendo garantido o 
fortalecimento da desigualdade e discriminação (ABREU; GARDINALI, 2016). O homem era o personagem principal dentro da sociedade e detinha autoridade na política, nas relações sociais, no trabalho, nas famílias e em demais espaços de prestígio (ZAULI; ROCHA; SALES, 2013).

O homem sendo a fonte provedora de recursos para o lar deixava implícita a não necessidade de a mulher ter renda. Aquelas que por algum motivo tinham que trabalhar, seja por fazerem parte de classes mais baixas ou por ficarem viúvas, eram vistas de maneira ruim pela sociedade (PROBST, 2003).

A partir do final do século passado, começaram a surgir novas formas de organização do processo produtivo e a globalização trouxe avanços tecnológicos e a alta competitividade. Nesse cenário, formas até então não tradicionais de trabalho começaram a surgir, como a terceirização, o trabalho em tempo parcial e outras alternativas. Para alguns empregadores, foi o mecanismo encontrado para se manterem competitivos no mercado, um importante fator para a sobrevivência de muitas empresas. A convicção de emprego estável e com possibilidade de permanência por toda a vida construída pelo capitalismo após a Segunda Guerra Mundial já não mais existia (WÜNSCH FILHO, 2004).

Essa nova realidade abriu possibilidade para a participação da mulher nas relações que envolvem o trabalho, tanto pela necessidade de complementação de renda nas famílias como pelas mudanças que aconteciam na sociedade naquele momento (AMARAL, 2013). Consequentemente, esse cenário gerou aumento significativo da presença da mulher em atividades produtivas, também por causa de transformações culturais, demográficas e sociais que modificaram o perfil das famílias. Essas mudanças geraram maior aceitação da mão de obra feminina como força de trabalho na sociedade. Como resultado, foi reduzida a taxa de fecundidade e aumentou o número de famílias brasileiras que têm a figura feminina como a mais importante na obtenção de recursos (BRUSCHINI; RICOLDI; MERCADO, 2008).

A partir desse período, começou a haver indagações sobre as condições das mulheres geradas por elas mesmas acerca de sua identidade, posição e papel na sociedade. Movimentos feministas iniciados na década de 1970 tiveram grande relevância para a evolução da causa dos direitos da mulher, e quanto mais esses movimentos se difundiam, 
motivavam importantes quebras referentes à individualidade, independência e verdadeira condição da mulher (KANAN, 2010).

Assim, conforme descrito pela ONU Mulheres Brasil, o feminismo abrange a luta pela igualdade:

Refere-se aos movimentos ou conjuntos de pensamentos político, filosófico e cultural que defendem a igualdade de direitos entre os homens e as mulheres. Muitas vezes, são alvo de conotações pejorativas, por se entender que se trata do contrário de machismo. No entanto, diferente do machismo, que prega a superioridade do homem sobre a mulher, o feminismo prega a igualdade de direitos e oportunidades entre homens e mulheres. (ONU MULHERES BRASIL, 2017, p. 21)

Com início em um movimento que foi impulsionado por uma necessidade de complementação de renda, a mulher começou a conquistar mais espaço nas questões que envolviam o trabalho e em outros ambientes que dependiam dessa dinâmica (CARVALHO NETO; TANURE; ANDRADE, 2010). Hoje, já não existem áreas ocupadas somente por homens, estando a mulher cada vez mais presente em variadas profissões e setores de maneira universal (PROBST, 2003). Mesmo assim, para sua permanência, a mulher requer adequação às exigências do ambiente e ao ecossistema que o trabalho oferece, tendo a necessidade da construção de sua identidade na luta pela igualdade de gênero (BARBOSA, 2013).

Segundo Probst (2003), também ligado a isso está um fator que contribui para o crescimento da força de trabalho feminina: a valorização de características ligadas ao ser feminino, como docilidade, trabalho em equipe, cooperação e persuasão. Desde modo, surgem na sociedade atual quebra de paradigmas, ruptura de barreiras do passado, alterações de concepções, diferentes modelos familiares e novos estilos de vida. Ainda que muitas barreiras não encontrem-se superadas e exista discriminações contra o ser feminino até hoje (KANAN, 2010).

\section{Desigualdade de gênero no trabalho}

Antes de tudo, é necessário destacar o que de fato significa igualdade de gênero. Para a ONU Mulheres Brasil: 
'Igualdade de gênero' refere-se ao conceito de que todos os seres humanos, sem diferenciação de sexo ou gênero, são livres para desenvolver as suas capacidades pessoais e tomar decisões sem as limitações impostas por papéis rigidamente atribuídos a um gênero. A igualdade de gênero significa que os diferentes comportamentos, aspirações e necessidades das mulheres e dos homens são considerados, valorizados e favorecidos equitativamente. Não significa que as mulheres e os homens têm de se tornar idênticos, mas que os seus direitos, responsabilidades e oportunidades não são determinados pelo seu gênero. (ONU MULHERES BRASIL, 2017, p.25)

Mesmo com o crescente aumento do trabalho da mulher nas mais variadas profissões, esse cenário não gerou um sistema igualitário, continuando a ser caracterizado como um mercado desigual, como tradicionalmente já era. Nesse contexto, as desigualdades não sumiram, apenas ficaram mais suaves e encobertas ao olhar da sociedade. Mesmo com modificações que têm acontecido tanto no setor público como no setor privado e com as conquistas por parte das mulheres, ainda há grandes abismos quando falamos de igualdade de gênero (CAPPELLE; MELO; SOUZA, 2004; AMARAL, 2012).

Dentre essas disparidades está a diferenciação da força de trabaIho que faz com que exista uma segregação trabalhista, podendo ser horizontal e vertical. A segregação horizontal traduz-se na inclinação de determinar o acesso de pessoas de diferentes gêneros a diferentes profissões, ao mesmo tempo em que a segregação vertical intimida a entrada da mulher nos cargos mais altos da estrutura hierárquica das organizações (BARROS, 2008; CAPPELLE; MELO; SOUZA, 2013).

Levando em conta a segregação horizontal, identifica-se o acúmulo de mulheres em profissões voltadas principalmente para cuidados e ajuda, sendo isso reflexo do papel de cuidadora que lhe foi atribuído socialmente e transposto para a esfera pública. Como reflexo dessa situação, é comum encontrar mulheres em profissões como enfermagem, ensino básico, fisioterapia, atendimento ao público e em funções de suporte. Por outro lado, os homens são encorajados a trabalhar em áreas como engenharia, indústria e negócios, são motivados a se ocuparem de funções de direção e planejamento, tendo 
o masculino cargos de prestígio e socialmente valorizados (ZAULI; ROCHA; SALES, 2013; SILVA et al., 2016).

Com os instrumentos apresentados cabe destacar a subvalorização da capacidade das mulheres, tendo como referência o baixo prestígio que as profissões a elas designadas socialmente possuem (AMARAL, 2012; ZAULI; ROCHA; SALES, 2013). A concentração de mulheres nessas áreas ocorre por ser mais fácil a aceitação de sua presença e atuação pela sociedade (CAPPELLE; MELO; SOUZA, 2013).

\section{Equidade de gênero nas empresas}

Existe alto grau de incerteza e grande concorrência no trabalho, o que faz com que as empresas sintam a imposição de rever suas práticas de gestão com o objetivo de acompanhar as tendências do cenário. Diante dessa conjuntura nasce a preocupação de achar profissionais qualificados e comprometidos, o que vem a colaborar para a disputa das mulheres por um lugar nesse mercado (BARBOSA, 2013). Lemos, Mello e Guimarães (2014) fortificam essa visão argumentando que esse olhar torna-se mais imediato no cenário atual, em que há alta competição entre as empresas, instabilidade das relações profissionais e alta demanda por pessoas qualificadas nas empresas, tornando-se relevante atrair e manter uma significativa parte da força de trabalho feminina.

As práticas de gestão estão sendo mudando nas empresas, e entre essas mudanças está a valorização da diversidade, que vem contribuindo para que o gênero feminino ganhe espaço dentro das organizações (BARBOSA, 2013). Esse movimento vem por consequência da necessidade de sobrevivência e crescimento das organizações, o que está ligado ao reconhecimento da diversidade que há nas pessoas. Assim, uma empresa que busca crescer e se desenvolver tem que saber valorizar a diversidade no seu quadro de funcionários. Porém, esse movimento de diversidade causa um grande desafio para muitas empresas, já que as lideranças de modo geral estabelecem uma lógica masculina (CAPPELLE; MELO; SOUZA, 2004; ZAULI; ROCHA; SALES, 2013). Dando sequência, torna-se essencial expor a existência dos chamados vieses inconscientes ou implícitos, que são 
[...] as preferências que ficam escondidas no inconsciente e que influenciam as atitudes, as percepções, os julgamentos e as ações das pessoas sem que elas percebam que estão dando vantagem para um determinado aspecto. (INSPER et al, 2016, p. 14)

Esse aspecto pode ser o gênero. Bastante comuns nas organizações, esses vieses podem ocorrer, por exemplo, no favorecimento de forma oculta de raça e/ou gênero no momento de uma contratação ou promoção de uma pessoa.

Seguindo nessa linha de pensamento, há cinco vieses principais que acontecem mais comumente e analisando-os podemos ver a situação desvantajosa da mulher em um ambiente majoritariamente masculino. São eles: viés da afinidade, que faz com que avaliemos melhor pessoas que se assemelham a nós; viés da percepção, em que pessoas reforçam estereótipos sem uma base sólida nos reais acontecimentos; viés confirmatório, que representa dar importância somente para informações que reafirmam nossas crenças e desconsiderar aquelas que trazem questionamentos; viés de halo/auréola, que é a vontade de analisar positivamente um conjunto só porque uma parte dele te satisfez; e viés de efeito grupo, em que existe uma tendência a reforçar e reproduzir comportamentos do grupo para não se distanciar do modelo que predomina (INSPER et al, 2016). Assim, afirma Kanan (2010), dentro das organizações, as práticas discriminatórias ou sexistas frequentemente são encobertas e negadas nas entrelinhas do que é feito e falado.

Para orientar e estimular empresas a agir em prol de mudanças pela busca da equidade de gênero em seus ambientes internos, nas cadeias de valor e comunidades em que atuam, a ONU Mulheres, junto com o Pacto Global, organizou os sete Princípios de Empoderamento das Mulheres, conhecidos pela sigla em inglês WEPs. São eles: estabelecer liderança corporativa sensível à igualdade de gênero entre cargos de mais alto nível; tratar todas as mulheres e homens de forma justa no trabalho, respeitando e apoiando os direitos humanos e a não discriminação; garantir a saúde, segurança e bem-estar de todos os gêneros que trabalham na empresa; promover educação, capacitação e desenvolvimento profissional para as mulheres; apoiar empreendedorismo de mulheres e promover políticas de empoderamento das 
mulheres por meio das cadeias de suprimentos e marketing; promover a igualdade de gênero através de iniciativas voltadas à comunidade e ao ativismo social; medir, documentar e publicar os progressos da empresa na promoção da equidade de gênero (INSPER et al, 2016).

Com esse contexto de procura por novas práticas para minimizarem discriminações de gênero nas organizações, Cappelle, Melo e Souza (2004) certificam que há uma modificação na perpetuidade da dominância do homem sobre a mulher dentro das organizações, mesmo que ainda haja traços significativos de discriminação nessa relação, sendo possível uma ruptura nos modelos de preconceito daqui a longos anos. Partilhando desse ponto de vista, Kanan (2010) considera possível que essa mesma sociedade que hoje se mostra discriminatória passe a assumir uma postura de mais apoio à independência da mulher.

\section{Dificuldades e impasses encontrados no trabalho por mu- Iheres}

Uma pesquisa realizada pela Thomson Reuters Foundation em 2015 em diversos países, entre eles o Brasil, identificou as cinco maiores dificuldades enfrentadas no trabalho pelas mulheres: conciliar trabalho com vida pessoal; disparidade salarial; assédio; oportunidade de carreira; aliar carreira e maternidade (THOMSON REUTERS, 2015). Tendo como direcionamento essas dificuldades de gênero, esta seção está dividida em quatro tópicos que detalham as dificuldades mais presentes: desigualdade salarial, assédio nas organizações, dificuldade de ascensão e conciliação entre vida pessoal e profissional.

\section{Desigualdade salarial}

Segundo Teixeira (2012), as desigualdades de salário se originam numa construção ideológica em que as mulheres têm menos necessidades de subsistência que os homens por não terem obrigações financeiras com a família. Nessa conjuntura, ela é vista como força de trabalho secundária e complementar ao papel do homem, caracterizado como único e principal provedor da família. Para a autora, esse cenário torna-se um grande obstáculo para a busca da igualdade salarial. 
Com base na teoria econômica, indivíduos com a mesma produtividade e que recebem salários diferentes por gênero ou raça, por exemplo, estão sofrendo discriminação na busca por emprego para exercer a mesma atividade (UHR, 2014). Araújo e Ribeiro (2002) lembram que a discriminação incide também na forma salarial, quando pessoas igualmente produtivas são avaliadas por características não produtivas. Dessa maneira, o gênero torna-se um fator condicionante de desigualdade salarial (MARQUES; FERREIRA, 2015).

O fato gerador da desigualdade salarial vem da discriminação ao diferenciar indivíduos com base em atributos visuais, como gênero e cor da pele, em que os prejulgamentos influenciam na discriminação, tirando a oportunidade desses indivíduos mostrarem sua capacidade (ARAÚJO; RIBEIRO, 2002).

\section{Assédio nas organizações}

Dentro das organizações, os assédios mais recorrentes são o moral e sexual. O primeiro tem como característica a recorrência de uma situação de constrangimento e humilhação contra o trabalhador, com o objetivo de intimidar, punir, desestabilizar emocionalmente e constranger. As ações podem ocorrer de forma direta (piadas constrangedoras, acusações, humilhações) ou de forma indireta (excluir do grupo, espalhar fofocas). Esse tipo de violência prejudica a produtividade de empregado e sua saúde mental e física, gerando impacto no contexto de trabalho (TOLFO; OLIVEIRA, 2013).

Já o assédio sexual pode ser caracterizado como uma maneira de discriminação sexual que tem um objetivo diferente de uma "cantada" por sua intencionalidade. Criando um paralelo entre a cantada e o assédio, podemos dizer que a primeira depende que a outra pessoa esteja em conformidade para haver uma relação amorosa, já o assédio tem objetivo autoritário, cruel e traz punição caso haja uma resposta negativa (FREITAS, 2001).

O Ministério Público do Trabalho (2017, p. 9) destaca que o assédio sexual difere-se do assédio moral pelo conteúdo sexual existente nos meios utilizados e nos fins desejados, definindo-o como uma "conduta de natureza sexual, manifestada fisicamente, por palavras, gestos ou outros meios, propostas ou impostas a pessoas contra sua vontade, 
causando-Ihe constrangimento e violando a sua liberdade sexual". O órgão considera o assédio sexual como mecanismo de violação dos Direitos Humanos por sua ordem opressiva e discriminatória que desrespeita os direitos fundamentais e a dignidade do indivíduo.

Há mais assédio contra mulheres do que homens muito pelo modelo de sociedade que vivemos, no qual há uma inferiorização do feminino perante o masculino (SIMÕES; MELLO, 2016). Como o homem ainda domina as relações de trabalho e ocupa cargos mais altos, sendo detentor do poder dentro das empresas, e a mulher acaba por ter carreiras de menor valor socialmente, isso contribui para a maioria das vítimas sejam mulheres (MINISTÉRIO PÚBLICO DO TRABALHO, 2017).

Com tudo o que foi relatado, o assédio sexual e moral é um problema organizacional e as empresas têm a necessidade e obrigação de desenvolver políticas para coibir esse tipo de prática, visto que são ambientes onde há regulação de comportamentos e é interesse dela inibir ações que possam afetar sua imagem ou rendimento (FREITAS, 2001).

Como é dever do empregador garantir um ambiente de trabalho sem que haja qualquer tipo de assédio, faz-se útil a criação de canais de denúncia dessas práticas, a inclusão do tema em treinamentos, divulgação do debate na empresa, criando a conscientização do trabalhador a respeito do tema e sua importância, ter regras de conduta em relação ao assédio nas normas, punições para ações desse tipo e outras providências que venham a coibir o assédio moral e sexual (MINISTÉRIO PÚBLICO DO TRABALHO, 2017).

\section{Dificuldade de ascensão}

É aparente a desigualdade de gênero no mercado de trabalho. Quando falamos de desigualdade vertical entre homens e mulheres, existe um fenômeno conhecido como teto de vidro que é caracterizado pela dificuldade que a mulher encontra para alcançar altos graus na hierarquia das empresas (VAZ, 2013). O teto de vidro é uma barreira transparente que se manifesta de forma sutil, mas muito eficaz para gerar desigualdade entre mulheres e homens porque dificulta o crescimento profissional para as altas posições dentro da organização. Essa barreira atrapalha a mulher para se desenvolver profissionalmente apenas pela questão do gênero (STEIL, 1997). Mendes (2017) reforça que ações de discriminação não 
ocorrem de forma clara, mas criam dificuldades para o crescimento da carreira feminina, o que justifica a analogia com o teto de vidro: é possível enxergar, mas não atravessar.

Fica evidente que quanto mais alto é o cargo na hierarquia da empresa, menor se torna a participação da mulher, também pela gestão ser relacionada há anos com o ser masculino e a mulher ter sido vista inicialmente como entrando em um ambiente que não é o seu (CARVALHO NETO; TANURE; ANDRADE, 2010).

Dando sequência, vê-se que determinados atributos e capacidades são usados para definir o que é considerado um comportamento de excelência no que diz respeito à liderança, comportamento que está ligado à figura masculina historicamente (KANAN, 2010). Essas convicções acerca do tema estão enraizadas na nossa sociedade tanto no pensamento do homem quanto no da mulher (BARBOSA, 2013).

Vendo que existe historicamente um movimento muito forte de colocação de líderes brancos e homens e tendo em vista que as pessoas preferenciam seus semelhantes, isso acaba gerando, preservando e alimentando a hierarquia da liderança do homem branco, já que líderes elegerão seus semelhantes, mesmo que de maneira involuntária ou automática (INSPER et al, 2016).

\section{Conciliação entre vida pessoal e profissional}

A divisão do trabalho na sociedade estabeleceu a mulher como responsável pela esfera privada reprodutiva (cuidados com o lar) e o homem pela esfera pública (trazer dinheiro) (HIRATA; KERGOAT, 2007).

Com a conquista de novos espaços, a mulher não deixou de realizar as tarefas oriundas do lar, continuando sendo a principal responsável pela execução e manutenção dos cuidados com a casa e filhos que the foram atribuídas historicamente (AMARAL, 2012). Mesmo com a mulher entrando na esfera pública, não houve inserção do homem na esfera reprodutiva (CARVALHO NETO; TANURE; ANDRADE, 2010; ORGANIZAÇÃO INTERNACIONAL DO TRABALHO, 2010). Dessa maneira, houve o acúmulo de funções para a mulher, com a responsabilidade pelos cuidados com o lar continuando nas mãos dela (VAZ, 2013). A mulher tem que conciliar as responsabilidades privadas e as demandas de seu trabalho, tornando difícil o crescimento profissional (BARBOSA, 2013). 
As empresas atualmente exigem um modelo de dedicação total do funcionário para que ele consiga progredir e crescer dentro das organizações, tendo tempo e disposição para dedicar-se ao que a empresa necessitar. Tendo isso em mente, a pessoa que tem outros afazeres fora do trabalho e que necessite de dedicação para outras funções, como cuidados com o lar e filhos, é a mulher (ORGANIZAÇÃO INTERNACIONAL DO TRABALHO, 2010).

Mesmo mulheres com boa condição financeira, que conseguem pagar por uma mão de obra barata para a realização de serviços do lar e cuidados com filhos, transferem essas funções para outras mulheres, continuando a recair sobre elas (CARVALHO NETO; TANURE; ANDRADE, 2010).

Segundo dados da Pesquisa Nacional por Amostra de Domicílios feita pelo IBGE (2016), não houve mudança expressivas nas funções dos homens e das mulheres na sociedade brasileira nos últimos dez anos, tendo a mulher duas vezes mais tempo de dedicação a atividades do lar se comparada ao homem.

\section{Metodologia}

As pesquisas podem ser classificadas, de acordo com Vergara (2013), a partir de dois critérios básicos: quanto aos fins e quanto aos meios. Quanto aos fins, a presente pesquisa se caracteriza como descritiva, visto que tem a finalidade de identificar opiniões, atitudes e crenças de determinada população, descrevendo características desta ou do fenômeno em estudo, ou mesmo estabelecer relações entre as variáveis (GIL, 2014).

Quanto aos meios utilizados para investigação, fez-se uso da pesquisa bibliográfica, desenvolvida com base em material já elaborado e publicado, como livros, revistas, redes eletrônicas e outros que estejam disponíveis ao público. Ainda foram feitas entrevistas, correspondendo à investigação empírica realizada no ambiente onde sucede ou sucedeu um fenômeno (VERGARA, 2013).

Será elaborado um estudo de caso, que é um método de pesquisa que utiliza em geral dados qualitativos, coletando informações através 
de eventos presentes no contexto a ser estudado e descrevendo fenômenos que acontecem neste ambiente (YIN, 2009).

$\mathrm{O}$ instrumento utilizado na pesquisa foram entrevistas, pois além de estarem voltadas aos objetivos específicos desse trabalho, trazem grande profundidade e fartura de informações para a elaboração desta pesquisa. Foram realizadas entrevistas semiestruturadas (LAKATOS, 1996) para que a entrevistada não se sentisse restrita, tendo liberdade para dissertar sobre o assunto proposto, a partir de um roteiro de perguntas guiadas para evitar hiatos durante a entrevista (TRIVINOS, 1987).

\section{Análise dos dados}

A pesquisa entrevistou apenas mulheres e por se tratar de um tema um tanto quanto complexo, julgou-se mais adequado preservar a identidade das entrevistadas a fim de que pudessem falar mais abertamente sobre o assunto, sem temer comprometer a si ou às organizações em que trabalham, que também tiveram seus nomes resguardados. Logo, foram atribuídos pseudônimos, escolhidos de maneira aleatória e sem qualquer ligação com os nomes verdadeiros, para substituir os nomes das entrevistadas.

O perfil das entrevistadas e das respectivas organizações pode ser verificado no Quadro 1. Na sequência, foram feitas as análises de cada questão respondida pelas entrevistadas.

Quadro 1. Perfil dos entrevistados

\begin{tabular}{|l|c|c|c|l|l|}
\hline Entrevistada & Idade & Filhos & $\begin{array}{c}\text { Tempo de } \\
\text { banco }\end{array}$ & \multicolumn{1}{|c|}{ Cargo } & $\begin{array}{c}\text { Banco onde } \\
\text { trabalha }\end{array}$ \\
\hline Francine & 59 anos & 0 & 30 anos & Gerente Geral & Banco X \\
\hline Janaína & 23 anos & 0 & 4 anos & Caixa & Banco Z \\
\hline Manuela & 25 anos & 2 & 8 anos & Caixa & Banco Z \\
\hline Mel & 38 anos & 2 & 10 anos & Caixa & Banco Y \\
\hline Patrícia & 31 anos & 0 & 12 anos & Gerente Geral & Banco Z \\
\hline Samanta & 26 anos & 1 & 11 anos & Agente Comercial & Banco Y \\
\hline Julia & 31 anos & 0 & 15 anos & Gerente Comercial & Banco X \\
\hline Suzzy & 32 anos & 2 & 13 anos & Agente Comercial & Banco Y \\
\hline
\end{tabular}

Fonte: Elaborado 0 autor. 
Como se sentem em relação a carreira sobre a possibilidade de ficar grávida?

Tendo esse questionamento colocado em pauta, a resposta foi unanime: todas as mulheres de diferentes cargos e idades acreditam que isso afetaria sua carreira. Houve um caso de uma entrevistada dizer que perdeu uma promoção, pois Ihe disseram que já que estava grávida, não haveria mais a possibilidade de promoção que até então era muito provável.

Foi colocado que quando se fica grávida, do período que se informa ao gestor até pelo menos um ano após a volta às funções, não existe nenhuma possibilidade de crescimento na carreira, tendo assim uma estagnação.

A partir dessa resposta como fundamentação e do embasamento teórico apresentado neste trabalho, percebe-se que acontece a mesma situação tanto no banco quanto no mercado de trabalho em relação ao desenvolvimento profissional no período que antecede e sucede a gravidez.

Sente que sua opinião é menos levada em consideração por ser mulher?

A maioria das mulheres entrevistadas não percebe que isso ocorra nas dinâmicas com seus pares e superiores, mas há uma pequena parte que entende que isso ocorre de forma sutil.

Entre as mulheres que representam a menor parte das opiniões, houve a citação de um caso em que a entrevistada levantou questionamentos plausíveis em reuniões e seus comentários não foram levados em consideração pela gerência, mas quando um colega homem expressou o mesmo ponto de vista, houve uma maior aceitação da gerência e sobre o tema.

Porém, em relação aos clientes, houve uma concordância quase que total de que clientes nem sempre acreditam em algo somente porque está sendo dito por uma mulher. Houve mais de uma citação de mulheres entrevistadas que afirmaram ter que chamar um colega homem para ajudar no fechamento de uma venda, pois o cliente não estava se sentindo convencido. 
Com isso, vemos que existe um preconceito social com raízes na nossa sociedade que estabelece uma relação de desconfiança ou descrédito da opinião de uma mulher e subjuga suas reais habilidades, colocando-a em segundo plano na comparação com um homem.

Considera o ambiente de trabalho igualitário para homens e mulheres?

A maior parte das mulheres entrevistadas enxerga que o banco é um ambiente igualitário e que as possibilidades são as mesmas, independente do gênero. Uma pequena parte acredita que há uma valorização de habilidades que estão mais relacionadas ao ser masculino e que isso acaba gerando vantagem para uma promoção.

Aqui, percebemos que há uma incongruência com o item 4.1, em que todas afirmaram acreditam que ficar grávida afeta sua carreira. Visto que isso não acontece com o homem, percebe-se uma possível normalização de determinados hábitos que existem no mercado de trabalho e no banco sobre a desigualdade em relação a carreira.

Como percebe a existência de piadas machistas dentro do banco?

A grande maioria das entrevistadas percebe que há piadas machistas no ambiente de trabalho bancário. Um exemplo é falar para uma mulher que vá trabalhar muito arrumada ou com uma roupa que valorize seu corpo que veio "com roupa para bater meta". Com isso, cria-se um julgamento das reais capacidades da mulher, colocando-a como objeto e desqualificando seu potencial.

Criando um paralelo com o mercado de trabalho e o referencial bibliográfico, percebe-se que esse comportamento de julgar a mulher pelo que ela aparenta fisicamente desqualificando suas reais habilidades é um processo que ainda ocorre.

Uma entrevistada afirmou que um colega costumava fazer piadas machistas utilizando-a como alvo, como uma maneira de tentar deixá-la constrangida. Esse comportamento ocorria na frente da equipe e do 
gestor, que por sua vez, apenas ria e achava graça tentando normalizar esse tipo de situação. Muito por esse tipo de confronto virar algo rotineiro, ela pediu para mudar de agência, pois não sabia exatamente o que poderia fazer, mas não queria continuar nesse ciclo.

Analisando esse caso, podemos perceber que a busca pela igualdade esbarra na naturalização de atos de desigualdade de gêneros que acabam por ser inseridos de forma tão natural que a própria vítima não sabe como recorrer dessa situação.

Sente que a gerência do banco intimida ou desmotiva a ficar grávida?

Essa foi uma questão em que houve uma divisão de opiniões. Algumas mulheres disseram que nunca passaram por isso, em geral mulheres que ocupam cargos mais altos no escopo organizacional, e em contrapartida mulheres que estão em cargos mais baixos disseram já ter sofrido ou presenciado alguma história que envolva essa dinâmica.

Houve uma situação citada por uma entrevistada em que uma funcionária da sua agência ficou grávida e o chefe disse que ela não poderia nem sonhar em ficar grávida naquele momento e, se estivesse pensando, para deixar mais para frente. A indignação da entrevistada mostrou-se na liberdade de seu corpo e suas vontades, segundo ela, não é algo que pense ou queira no momento, mas a falta de liberdade que sentiu a constrangeu e, nas palavras dela, a deixou sem reação.

Outro caso citado foi o de uma amiga da entrevistada que ficou grávida e no sétimo mês de gestação perdeu o bebê por complicações durante a gravidez. Ela teve direito à licença maternidade e quando retornou, no mês seguinte foi mandada embora. Essa pessoa acredita que o fato de ela ter ficado grávida, perdido o bebê e mesmo assim saído de licença prejudicou sua permanência na empresa. Porém, ela não saiu da área e quando foi fazer um processo seletivo para outro banco, uma das perguntas que o $\mathrm{RH}$ fez a ela foi sobre a vontade de ficar grávida e como era isso neste momento da sua vida. A entrevistada 
se sentiu péssima, pois ainda vivenciava seu período de recuperação e teve que omitir isso para conseguir o emprego.

Dentro dessa relação percebemos que o mercado de trabalho e o que é colocado no referencial teórico acabam se alinhando, tendo a maternidade como grande barreira para crescimento e manutenção do emprego.

Como enxerga os questionamentos sobre seu mérito profissional no banco?

A maior parte das mulheres sente que existe um questionamento do seu mérito pela parte dos clientes, que não acreditam que elas possam estar ocupando cargos de liderança ou ser a agente que irá resolver e trazer a solução para suas demandas. No ponto de vista das mulheres bancárias, isso ocorre porque acreditam que quando um homem fala transmite mais segurança.

Em relação ao mercado de trabalho como um todo, vemos que há uma existência de questionamentos sobre o mérito da mulher, como mostrado no referencial teórico. Isso acontece pelo modelo de sociedade baseado no homem como responsável pelo ambiente social, sendo a figura que detém o conhecimento.

Em contrapartida as mulheres não sentem esse questionamento por seus pares e parceiros no banco. Uma das justificativas segundo as entrevistadas é que o escopo das agências bancárias é de muito mais mulheres do que homens, sendo assim, levantar qualquer questionamento sobre o mérito de uma mulher levaria ao questionamento de várias, o que poderia gerar uma situação desconfortável e sem apoio de quem levantasse essa opinião.

Aqui vemos um diferença entre as mulheres bancárias e a mulher no mercado de trabalho, uma necessidade de provação muito maior para a mulher no mercado de trabalho do que para a mulher bancária, sendo o banco, muito pelo seu quadro de funcionários em que há de mais mulheres, um local com condições mais favoráveis que o mercado de trabalho. 
Como percebe a necessidade de uma maior qualificação da mulher perante o homem no banco?

De uma maneira geral, as mulheres no banco não sentem isso, acreditam que não é algo que acontece nesse ambiente de trabalho, sendo possível uma mulher com uma maior ou menor qualificação profissional ser promovida frente a um homem.

Isso se dá, segundo a opinião das entrevistadas, por ser um ambiente meritocrático e que seus resultados irão depender do seu desempenho em vendas, sendo esse fator determinante para uma promoção.

Essa questão se choca com o mercado, pois a mulher bancária não sente o mesmo impacto para crescer em agência que uma mulher em outras áreas. No banco, por haver um foco maior em resultados, o desempenho fica validado pelas vendas, e não pelo currículo.

Dessa maneira, vemos uma diferença relevante a respeito de como se dão as relações no banco e no mercado de trabalho, sendo mais favorável o crescimento da mulher no banco do que fora dele.

Qual a percepção sobre assédio no banco exclusivamente por ser mulher?

De acordo com as entrevistadas o assédio existe, mas por parte dos clientes, que às vezes confundem uma atenção ou atos educados com algum interesse amoroso, sendo o homem o único ser causador desse assédio. Já no ambiente que envolve seus pares, parceiros e gestores, apenas uma pessoa informou que já passou por isso. Algumas entrevistadas acreditam que não haja esse assédio por ser um ambiente onde há mais mulheres que homens, não havendo espaço para qualquer tipo de manifestação desse tipo.

O caso da entrevistada que se sentiu assediada por um par foi quando um cliente iria fechar uma negociação e a gerente sabia que o cliente queria sair com essa funcionária, e justamente por ter essa informação, pedia para ela sempre ir buscar algo para trazer para tentar induzir o cliente a fechar o negócio, sendo que a entrevistada se 
sentiu péssima e não sabia como reagir, pois na época era estagiária e precisava do emprego.

Vemos que esse tipo de assédio torna-se presente no banco sempre pela figura masculina, que por deter algum poder (seja ele o de compra, como no caso citado), utiliza desse viés para buscar relações amorosas com a mulher. Situação não tão diferente da que se encontra no mercado de trabalho, em que há índices de assédio também.

Como se sente sobre a liberdade de usar uma roupa sem se sentir assediada no banco?

A resposta foi unânime em não se sentir confortável em usar qualquer tipo de roupa. Esse desconforto parte tanto por receio de os clientes "darem em cima" quanto dos próprios pares e gestores julgarem de maneira negativa ou fazerem piadas a respeito da roupa que estão vestindo.

Uma entrevistada relatou que um cliente uma vez disse a ela que a cara de santa dela não o enganava e ela deveria fazer de tudo na cama. Nesse dia a entrevistada estava de vestido e esse cliente puxou o seu vestido, deixando-a seminua no hall da agência na frente de outros cliente e seu pares e gestor. Questionada sobre o tipo de sentimento que teve, disse que ficou com raiva, pois ninguém foi ajudá-la, e ao mesmo tempo vergonha, pois nunca deu liberdade para nenhum cliente. Depois do ocorrido, afirmou que não consegue usar vestido nem para sair na noite, pois tem medo de que algo parecido volte a acontecer.

Muitas das entrevistadas levantaram a questão de pares praticando assédio dizendo que vieram para vender por causa da sua roupa, colocando-as como objeto. Um caso em particular foi de uma entrevistada que ouviu da gestora que teria que colocar uma renda nas suas blusas por elas estarem muito curtas e de uma cliente que o marido dela não viria naquela agência por causa da roupa inadequada da funcionária.

Em relação à liberdade do corpo da mulher, tanto no banco quanto no mercado de trabalho são vivenciadas experiencias similares. Várias entrevistadas afirmaram que já trocaram de roupa antes de saírem de 
casa não por acharem a roupa inadequada, mas por acreditarem que alguém pudesse comentar.

\section{Conclusão}

Na sociedade, a desigualdade de gênero sempre esteve presente. Mesmo com algumas mudanças, ainda há muitas relações desiguais que são sustentadas pelo modelo patriarcal que a nossa sociedade formou, no qual há uma inferiorização da mulher frente ao homem. Essas desigualdades estão presentes tanto no trabalho quanto na política, nos comportamentos sociais, entre outros.

Dessa maneira, este trabalho se propôs a analisar a percepção de mulheres bancárias sobre o tema de desigualdade de gênero em seu ambiente de trabalho. Com isso foram definidos objetivos específicos para garantir o sucesso desta pesquisa.

Inicialmente foi realizada uma revisão bibliográfica sobre temas importantes para dar sustentação e forma ao trabalho, e mais a frente, através dos embasamentos feitos por meio do referencial teórico, foi decidida a metodologia.

Foram feitas entrevistas com mulheres funcionárias de diferentes bancos e diferentes áreas dentro de uma agência para entender como é o ambiente e suas especificidades.

Com a coleta dos dados, pude perceber que existem algumas diferenças sentidas entre a mulher que trabalha em banco e a mulher no mercado de trabalho, questões que envolvem promoções, por exemplo, aparecem de forma igual entre homens e mulheres no setor bancário. Mas muitas questões ruins que a mulher sofre no mercado de trabalho a bancária também sofre, como o assédio sexual e a dificuldade de conciliação entre vida pessoal e profissional.

Com a análise desse trabalho, percebe-se que o mercado de trabalho, assim como os bancos, ainda não conseguiu abranger e nem igualar os direitos entre os gêneros, deixando essa situação muito mais favorável ao homem. 
Esse tema torna-se muito complexo na sociedade atual e mesmo a passos lentos, a mulher está ganhando cada vez mais visibilidade e possibilidade de atuar com todo o seu potencial para se desenvolver.

\section{Refefências}

ABREU, Helen Ribeiro; GARDINALI, Maraisa. O assédio sexual como obstáculo à igualdade material de gênero. Revista Omnes, Brasília, v. 3, n. 1, p.97-115, 2016. Disponível em: https://bit.ly/2EYud0C. Acesso em: 5 jun. 2019.

ARAÚJO, Verônica Fagundes; RIBEIRO, Eduardo Pontal. Diferenciais de salários por gênero no Brasil: uma análise regional. Revista Econômica do Nordeste, Fortaleza, v. 33, n. 2, p.196-217, 2002. Acesso em: 3 set. 2019.

AMARAL, Graziele Alves. Os desafios da inserção da mulher no mercado de trabalho. Itinerarius Reflectionis, Jataí, v. 8, n. 2, 1 fev. 2012. Disponível em: https://bit.ly/31W6qHN. Acesso em: 3 set. 2019.

BARBOSA, Rosimar Pereira. Relações de gênero e a lógica da competência no mercado de trabalho. Revista de Carreiras e Pessoas, São Paulo, v. 3, n. 2, p. 36-52, 2013. Disponível em: https://bit.ly/2OOlJv0. Acesso em: 10 out. 2019.

BARROS, A. M. Cidadania, Relações de Gênero e Relações de Trabalho. Revista do Tribunal Regional do Trabalho da $3^{\circ}$ Região, Belo Horizonte, v. 47, n. 77, p. 67-83, jun. 2008.

BRUSCHINI, Cristina; RICOLDI, Arlene Martinez; MERCADO, Cristiano M. Trabalho e gênero no Brasil até 2005: uma comparação regional. In: COSTA, Albertina de Oliveira et al. (org.). Mercado de Trabalho e Gênero: comparações internacionais. Rio de Janeiro: Editora FGV, 2008.

CALÁS, Marta B.; SMIRCICH, Linda. Do ponto de vista da mulher: abordagens feministas em estudos organizacionais. In: CLEGG, Stewart R.; HARDY, Cynthia; NORD, Walter (org.). Handbook de Estudos Organizacionais, v.1. São Paulo: Atlas, 1999. 
CAPPELLE, Mônica Carvalho Alves; MELO, Marlene Catarina de Oliveira Lopes; SOUZA, Natácia Lamoglia de. Mulheres, trabalho e administração. Revista Interdisciplinar de Gestão Social, Salvador, v. 2, n. 2, p. 161-191, 2013. Disponível em: https://bit.ly/2YZ4XhZ. Acesso em: 10 mar. 2019.

CARVALHO NETO, Antonio Moreira de; TANURE, Betania; ANDRADE, Juliana. Executivas: carreira, maternidade, amores e preconceitos. Revista de Administração de Empresas, São Paulo, v. 9, n. 1, p. 1-23, 2010. Disponível em: https://bit.ly/3i94QaU. Acesso em: 4 abr. 2019.

COMISSÃO PARA A IGUALDADE NO TRABALHO E NO EMPREGO. Manual de Formação de Formadores/as em Igualdade de Oportunidades entre Mulheres e Homens. Lisboa: CITE, 2003. Disponível em: http:// cite.gov.pt/imgs/downlds/Manual_CITE.pdf. Acesso em: 5 abr. 2019.

FREITAS, Maria Ester de. Assédio moral e assédio sexual: faces do poder perverso nas organizações. Revista de Administração de Empresas, São Paulo, v. 41, n. 2, p. 8-19, 2001. Disponível em: https:// bit.ly/2EZD8z0. Acesso em: 9 ago. 2019.

FLEURY, Maria Tereza Leme. Gerenciando a diversidade cultural: experiências de empresas Brasileiras. Revista de Administração de Empresas, São Paulo, v. 40, n. 3, p. 18-25, 2000. Disponível em: https:// bit.ly/2QOhnoq. Acesso em: 3 set. 2020.

FONTOURA, Natália de Oliveira; GONZALEZ, Roberto. Aumento da participação de mulheres no mercado de trabalho: mudança ou reprodução da desigualdade? Boletim Mercado de Trabalho, Brasília, n. 41, p.21-26, 2009. Disponível em: https://bit.ly/3INFfXv. Acesso em: 20 abr. 2019.

GIL, Antônio Carlos. Métodos e Técnicas de Pesquisa Social. 6. ed. São Paulo: Atlas, 2014.

HIRATA, Helena; KERGOAT, Danièle. Novas configurações da divisão sexual do trabalho. Cadernos de Pesquisa, São Paulo, v. 37, n.132, p. 595-609, 2007. Disponível em: https://bit.ly/3gWnpOp. Acesso em: 26 out. 2019.

HOFFMANN, Rodolfo; LEONE, Eugênia Troncoso. Participação da mulher no mercado de trabalho e desigualdade da renda domiciliar per capita no Brasil: 1981-2002. Nova Economia, Belo Horizonte, v. 14, n. 2, 2009. Disponível em: https://bit.ly/3bwZJ24. Acesso em: 3 set. 2020 . 
INSPER et al. Vieses inconscientes, equidade de gênero e o mundo corporativo: lições da oficina "vieses inconscientes". São Paulo: Insper, 2016. Disponível em: https://bit.ly/3IHU7GV. Acesso em: 20 ago. 2019.

KANAN, Lilia Aparecida. Poder e liderança de mulheres nas organizações de trabalho. Revista Organizações \& Sociedade, Salvador, v. 17, n. 53, p.243-257, 2010. Disponível em: https://bit.ly/31TC5cJ. Acesso em: 10 nov. 2019.

LAKATOS, Eva Maria; Marconi, Marina de Andrade. Técnicas de pesquisa. 3 ed. São Paulo: Atlas, 1996.

LEMOS, Ana Heloísa Costa; MELLO, Giselle Rohr; GUIMARÃES, Mayara Farias. Gerações produtivas e carreiras: o que as mulheres da Geração Y querem? Revista de Administração da UFSM, Santa Maria, v. 7, n. 1, p. 135-152, 2014. Disponível em: https://bit.ly/3IRMvBQ. Acesso em: 30 nov. 2019.

MARQUES, Tânia de Matos Gomes; FERREIRA, Célia Melo. Mulheres na gestão de topo: A problemática do gap de gênero e salarial. Revista Ibero-Americana de Estratégia, São Paulo, v. 14, n. 1, p. 43-59, 2015. Disponível em: https://bit.ly/3jJ99Kv. Acesso em: 12 mar. 2019.

MENDES, Andréa Peres. Labirinto de Cristal: Mulheres, Carreira e Maternidade uma conciliação possível?. 2017. Dissertação (Mestrado em Psicologia Social) - Pontifícia Universidade Católica de São Paulo, São Paulo, 2017. Disponível em: https://bit.ly/3oFS5sk. Acesso em: 22 abr. 2019.

MINISTÉRIO PÚBLICO DO TRABALHO. Assédio Sexual no Trabalho: perguntas e respostas. Brasília, DF: Ministério Público do Trabalho, 2017. Disponível em: https://bit.ly/3kGtMYQ. Acesso em: 15 ago. 2019.

ORGANIZAÇÃO INTERNACIONAL DO TRABALHO. Igualdade de gênero e raça no trabalho: avanços e desafios. Brasília: OIT, 2010. Disponível em: https://bit.ly/3h09Ayi. Acesso em: 3 set. 2019.

OLIVEIRA, Sidinei Rocha de; PICCININI, Valmiria Carolina. Mercado de trabalho: múltiplos (des)entendimentos. Revista de Administração Pública, Rio de Janeiro, v. 45, n. 5, p. 1517-1538, 2011. Disponível em: https://bit.ly/32Ygn6P. Acesso em: 3 set. 2019.

ONU MULHERES BRASIL. Princípios de empoderamento das mulheres. Brasília: ONU Mulheres, 2017. Disponível em: https://bit.ly/3bqZOfs. Acesso em: 24 mar. 2019. 
PROBST, Elisiana Renata. A evolução da mulher no mercado de trabalho. Instituto Catarinense de Pós-Graduação, Itajaí, v. 2, n. 1, p. 1-8, 2003. Disponível em: https://bit.ly/2Dvxcxg. Acesso em: 15 maio 2019.

SANTOS, Juliana Anacleto dos. Desigualdade Social e o Conceito de Gênero. Revista Virtú, Juiz de Fora, 2010. Disponível em: https://bit.ly/2QUKUgd. Acesso em: 21. mar. 2019.

SCOTT, J. W. Gênero: Uma categoria útil para análise histórica. Cadernos de História UFPE, Recife, p. 9-39, 1990.

SILVA, Pablo Marlon Medeiros da et al. Equidade de gênero nas organizações: o trabalho e os desafios da mulher na construção civil. Revista Organizações em Contexto, São Bernardo do Campo, v. 12, n. 24, p. 283-305, 2016. Disponível em: https://bit.ly/3kMbENm. Acesso em: 22 mar. 2019.

SIMÕES, Ana Paula Arrieira; MELLO, Kauana Andriele de. A Discriminação de Gênero no Ambiente de Trabalho: particularidades e efeitos do assédio moral contra as mulheres. In: Seminário Internacional: Demandas sociais e políticas públicas na sociedade contemporânea, 13., 2016, Santa Cruz do Sul. Anais [...]. Santa Cruz do Sul: UNISC, 2016. Disponível em: https://bit.ly/3bnNMeZ. Acesso em: 3 set. 2019.

SOUZA, Vera Lúcia Pereira de; AMORIM, Tânia Nobre Gonçalves Ferreira; SILVA, Ladjane de Barros. O estágio: ferramenta fundamental para a inserção no mercado de trabalho? Revista de Administração, Contabilidade e Economia, Joaçaba, v. 10, n. 2, p. 269-294, 2011.

STEIL, Andrea Valéria. Organizações, gênero e posição hierárquica: compreendendo o fenômeno do teto de vidro. Revista de Administração, São Paulo, v. 32, n. 3, p. 62-69, 1997. Disponível em: https://bit.ly/35KvMsO. Acesso em: 15 out. 2019.

TEIXEIRA, Michele da Silva. Perfil da mulher no mercado de trabalho. Id On Line Revista de Psicologia, Jaboatão dos Guararapes, vol. 6, n. 17, p. 95-123, 2012. Disponível em: https://bit.ly/2Z26xiU. Acesso em: 22 abr. 2019.

THOMSON REUTERS. The top five issues facing woman at work. Blog Thomson Reuters, Nova lorque, 16 jan. 2015. Disponível em: https:// tmsnrt.rs/3jJhbmD. Acesso em: 30 set. 2019.

TRIVINOS, Augusto Nibaldo Silva. Introdução à pesquisa em ciências sociais: a pesquisa qualitativa em educação. São Paulo: Atlas, 1987. 
TOLFO, Suzana da Rosa; OLIVEIRA, Renato Toccheto de. Assédio Moral no Trabalho: uma violência a ser enfrentada. Florianópolis: UFSC, 2013. Disponível em: https://bit.ly/2EVYJsj. Acesso em: 9 nov. 2019.

UHR, Daniel de Abreu Pereira et al. Um estudo sobre a discriminação salarial no mercado de trabalho dos administradores do Brasil. Revista de Economia e Administração, São Paulo, v. 13, n. 2, p. 194-213, 2014. Disponível em: https://bit.ly/3h0bn6v. Acesso em: 25 nov. 2019.

VAZ, Daniela Verzola. O teto de vidro nas organizações públicas: evidências para o Brasil. Economia e Sociedade, Campinas, v. 22, n. 3, p. 765-790, 2013. Disponível em: https://bit.ly/2QRdpLM. Acesso em: 25 out. 2019.

VERGARA, Sylvia Constant. Projetos e Relatórios de Pesquisa em Administração. 14. ed. São Paulo: Atlas, 2013.

WÜNSCH FILHO, Victor. Perfil epidemiológico dos trabalhadores. Revista Brasileira de Medicina do Trabalho, Belo Horizonte, v. 2, n. 2, p. 103-117, 2004. Disponível em: https://bit.ly/2QUFGkz. Acesso em: 4 set. 2020.

YIN, Robert K. Case study research: design and methods. Thousand Oaks: Sage Publications, 2009.

ZAULI, Amanda; ROCHA, Candyce da Cruz; SALES, Clarissa Tolentino Ribeiro. Reflexões sobre diversidade e gênero. Brasília: Edições Câmara, 2013. E-book. Disponível em: https://bit.ly/31WzO0p. Acesso em: 18 mar. 2019. 



\title{
Inclusão de pessoas com deficiência na indústria farmacêutica: o caso da Roche
}

\author{
Mariáh de Lima \\ Luciane Tudda
}

\begin{abstract}
Resumo
O objetivo do trabalho foi contribuir para a formulação de novas políticas de inclusão de Pessoas com Deficiência (PCD) para empresas, tanto do ramo farmacêutico quanto para outras, através de um estudo de caso com a empresa Roche Diagnóstica Brasil. Buscou-se também identificar o perfil de funcionários PCD da empresa por meio de uma pesquisa qualitativa e analisar a legislação existente no Brasil para a inclusão de pessoas com deficiência no trabalho. Apesar de não haver uma política específica para a inclusão de PCD, a empresa Roche está acima da cota mínima, possui um Grupo de Diversidade para buscar melhorias e tornar a inclusão dentro da empresa algo natural e conta com o auxílio de uma consultoria externa para buscar funcionários para cargos mais altos. No Brasil, há leis que asseguram e promovem o exercício dos direitos e das liberdades fundamentais para pessoas com deficiência, sendo a Lei de Cotas de 1991 de fundamental importância para garantir um trabalho digno para PCD.
\end{abstract}

Palavras-chave: Pessoas com Deficiência. Políticas de inclusão. Diversidade. Empresas farmacêuticas. Legislação brasileira. 


\section{Introdução}

Muito se tem falado sobre inclusão social. É um tema que tem ganhado espaço em âmbito internacional e que também está sendo muito difundido no Brasil devido à miscigenação. Temos observado o aumento de projetos e ações sociais nas áreas de educação, esporte, saúde, política e no trabalho.

Quando se pensa em inclusão social, uma das primeiras coisas que as pessoas associam são as Pessoas com Deficiência (PCD), porém o termo é muito mais abrangente: envolve raça, cor, identidade de gênero, religião, entre outras categorias.

A inclusão é um paradigma que se aplica aos mais variados espaços físicos e simbólicos. Os grupos de pessoas, nos contextos inclusivos, têm suas características idiossincráticas reconhecidas e valorizadas. Segundo esse paradigma, identidade, diferença e diversidade representam vantagens sociais que favorecem o surgimento e o estabelecimento de relações de solidariedade e de colaboração (CAMARGO, 2017).

Incluir quer dizer fazer parte, ou seja, inclusão é a ação de inserir alguém ou um grupo representativo na sociedade. Portanto, pode-se dizer que incluir uma pessoa com deficiência significa torná-la participante da vida social, econômica e política e assegurar o respeito aos seus direitos (SPINIELI, 2019).

O Decreto $n^{\circ}$ 5.296/2004 e suas alterações consideram como deficiência: deficiência física, deficiência auditiva, deficiência visual, deficiência intelectual e deficiência múltipla (PESSOA..., 2017).

Em função da situação econômica no Brasil e da política presente, o índice de desemprego atual é de 11,8\%, o que corresponde a 12,6 milhões de pessoas (ABDALA, 2019), demonstrando a dificuldade do brasileiro para conseguir um emprego. Devido à concorrência, as pessoas devem estar sempre em busca de ampliar seus conhecimentos através de cursos de pós-graduação, mestrado, doutorado e até mesmo técnicos que possam agregar conhecimentos teóricos e práticos às suas áreas, ou até mesmo trazer visões diferentes para um negócio. 
Pessoas com Deficiência possuem a mesma dificuldade, porém ainda encontram resistência em suas contratações devido ao preconceito e ignorância de alguns empregadores. Portanto, a integração de PCD no processo produtivo é um dos maiores obstáculos para a sua inclusão social. De acordo com o Censo da Educação Superior (2016), apenas 0,45\% do total de 8 milhões de matrículas no ensino superior são de alunos com deficiência. Na rede privada, o percentual é ainda menor, $0,35 \%$, enquanto na rede pública ele chega a $0,73 \%$ (MATRíCULAS..., 2018). Ou seja, não são pessoas menos qualificadas ou capacitadas para exercer funções dentro das empresas, inclusive em cargos mais altos (COMO..., 2017).

Contudo, o direito a uma vida tão plena quanto possível para esses indivíduos ainda depende da implementação de políticas afirmativas que busquem assegurar os direitos fundamentais dessas pessoas, dentre eles o direito ao trabalho (BELTRÃO; BRUNSTEIN, 2012).

No Brasil, existe a Lei Brasileira de Inclusão de Pessoa com Deficiência, $n^{\circ}$ 13.146/2015, a qual garante às PCD o direito do trabalho de sua livre escolha e aceitação, garantindo a igualdade de oportunidades com as demais.

Em 1991, foi criada a Lei n. 8.213/1991, a qual obriga que as empresas com mais de cem funcionários tenham uma cota de contratação de PCD entre $2 \%$ e $5 \%$, dependendo da quantidade de trabalhadores.

Dados do ano 2000 apontam que apenas cinco estados possuem uma proporção de PCD empregados no mercado de trabalho superior ao piso de $2 \%$. Esses números revelam um alto grau de descumprimento da lei pelas empresas, a existência de um amplo espaço para o aumento da efetividade da lei e a necessidade de diminuir a perda de eficiência econômica e aumentar a eficácia de políticas voltadas à inclusão social das PCD (COSTILLA; NERI; CARVALHO, 2002).

O tema do trabalho foi escolhido devido a observação, em pouco tempo, da quantidade de PCD que trabalham na empresa Roche Diagnóstica Brasil, do trabalho que realizam e principalmente das oportunidades que são oferecidas no ambiente corporativo. Em outras empresas em que trabalhei, não observei a receptividade e participação de PCD no trabalho. Além disso, o tema é relevante para a gestão de pessoas ou recrutamento para a área da administração. 
Nas indústrias farmacêuticas, principalmente na área operacional, a contratação de funcionários com deficiências mais graves é praticamente impossível, pois exige uma habilidade maior por se tratar, muitas vezes, de um trabalho manual, e pelo risco de acidentes. Porém, nas áreas administrativas, não há esse tipo de restrição, possibilitando a contratação de PCD e trazendo mais diversidade a empresa.

Essa pesquisa buscou responder a seguinte questão: quais ações empresas farmacêuticas utilizam para a inclusão de Pessoas com Deficiência no ambiente corporativo e qual a percepção das PCD em relação à inclusão?

O trabalho teve como objetivo principal contribuir para que as empresas formulem novas ações para questões relacionadas a problemas de inclusão social, com foco em Pessoas com Deficiência. Apresentou, ainda, os seguintes objetivos secundários:

- Identificar o perfil dos funcionários com deficiência da empresa;

- Analisar as políticas de inclusão da empresa;

- Analisar a legislação existente no Brasil para a inclusão de Pessoas com Deficiência no trabalho.

\section{Diversidade, deficiência e inclusão}

\section{Diversidade}

No ambiente organizacional, mesmo com o processo de abertura de mercados e a homogeneização de discursos e modelos de gestão, continuam coexistindo as particularidades, as diferenças locais e o compartilhamento de crenças comuns.

O reconhecimento do outro como diferente é um avanço para que haja melhoria da convivência de pessoas, sociedades e organizações, pois favorece o respeito mútuo, a diminuição de estereótipos, de incompreensões e de dificuldades de interação. Também aumenta a qualidade das decisões tomadas no ambiente de trabalho, além da tendência à formação de um ambiente cada vez mais qualificado, diverso, porém, mais sujeito a conflitos e exclusão (BUENO; FREITAS, 2018). 
As políticas públicas para todos os segmentos da sociedade - grupos de mulheres, estudantes, jovens, idosos, indígenas, pessoas com deficiência, pessoas carentes, entre outros - são ações importantes que buscam assegurar os direitos de cidadania previstos constitucionalmente, e que se afirmam graças ao reconhecimento por parte da sociedade ou pelos poderes públicos (SCARANO, 2018).

A exclusão e a segregação de Pessoas com Deficiência cederam espaço à ideia de integração e, atualmente, à de inclusão social. Nesse novo cenário, a capacidade laborativa desse grupo começa a ser considerada. O enfoque caminha do modelo médico, em que a deficiência é considerada uma doença e seu portador deve ser cuidado como um dependente, para o modelo social, em que prioriza-se o olhar sobre a contribuição que a pessoa pode dar à sociedade, a qual será, por sua vez, corresponsável por seu desenvolvimento (BELTRÃO; BRUNSTEIN, 2012).

\section{Deficiências, perfil e inclusão de PCD no Brasil}

A Lei $n^{\circ}$ 13.146, de 6 de julho de 2015, conhecida como Estatuto da Pessoa com Deficiência, conceitua no artigo $2^{\circ}$ a expressão "pessoa com deficiência":

Considera-se pessoa com deficiência aquela que tem impedimento de longo prazo de natureza física, mental, intelectual ou sensorial, o qual, em interação com uma ou mais barreiras, pode obstruir sua participação plena e efetiva na sociedade em igualdade de condições com as demais pessoas. (BRASIL, 2015)

No Brasil, as diferentes formas de deficiência - física, auditiva, visual, intelectual e múltipla - estão consideradas no Decreto $n^{\circ}$ 5.296/2004, artigo $5^{\circ}$ :

Deficiência física: alteração completa ou parcial de um ou mais segmentos do corpo humano, acarretando o comprometimento 
da função física, apresentando-se sob a forma de paraplegia, paraparesia, monoplegia, monoparesia, tetraplegia, tetraparesia, triplegia, triparesia, hemiplegia, hemiparesia, ostomia, amputação ou ausência de membro, paralisia cerebral, nanismo, membros com deformidade congênita ou adquirida, exceto as deformidades estéticas e as que não produzam dificuldades para o desempenho de funções. (BRASIL, 2004)

Já a pessoa com deficiência auditiva é aquela que tem "perda bilateral, parcial ou total, de quarenta e um decibéis $(\mathrm{dB})$ ou mais, aferida por audiograma nas frequências de $500 \mathrm{~Hz}, 1.000 \mathrm{~Hz}, 2.000 \mathrm{~Hz}$ e $3.000 \mathrm{~Hz}$ " (BRASIL, 2004).

A deficiência visual é definida como: cegueira, na qual a acuidade visual é igual ou menor que 0,05 no melhor olho, com a melhor correção óptica; baixa visão - a qual significa acuidade visual entre 0,3 e 0,05 no melhor olho, com a melhor correção óptica; e também os casos nos quais a somatória da medida do campo visual em ambos os olhos for igual ou menor que $60^{\circ}$; ou até mesmo a ocorrência simultânea de quaisquer das condições anteriores.

A deficiência intelectual, a qual originalmente era denominada mental, é quando a pessoa tem o funcionamento intelectual significativamente inferior à média, que se manifesta antes dos dezoito anos, e a qual a limitação está associada a duas ou mais áreas de habilidades adaptativas (comunicação, cuidado pessoal, habilidades sociais, utilização dos recursos da comunidade, saúde e segurança, habilidades acadêmicas, lazer e trabalho).

E por último, a deficiência múltipla, que nada mais é do que a associação de duas ou mais deficiências (PESSOA..., 2017).

Segundo dados do IBGE para o ano de 2010 (IBGE EDUCA, 2019), havia no Brasil 12,5 milhões de pessoas que possuíam grande ou total dificuldade para enxergar, ouvir, caminhar ou subir degraus (ou seja, pessoas com deficiência nessas habilidades), além dos que declararam ter deficiência mental ou intelectual, o que correspondia a 6,7\% da população. No Gráfico 1, podemos ver a porcentagem da população com deficiência no ano de 2010, dividida por tipo e grau de dificuldade. 


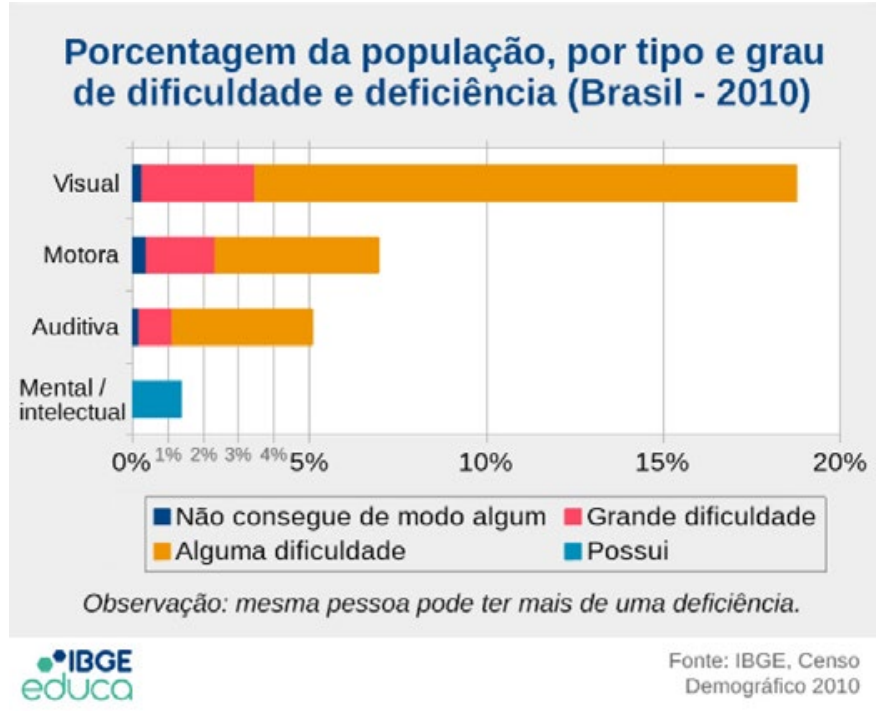

Gráfico 1. A deficiência visual estava presente em 3,4\% da população brasileira, seguida pela deficiência motora $(2,3 \%)$, deficiência auditiva $(1,1 \%)$ e deficiência mental/intelectual $(1,4 \%)$

Fonte: IBGE, Censo Demográfico (2010).

Dados da Unesco sobre 2019 apontam que o número de Pessoas com Deficiência no Brasil aumentou para 45,6 milhões de pessoas (24\% da população), o que pode ser justificado pela atualização da definição de deficiência e também pelas pessoas começarem a assumir suas deficiências, que poderiam ser motivo de preconceito.

Um dos motivos que explicam a participação insuficiente de Pessoas com Deficiência no mercado de trabalho brasileiro é a baixa escolaridade. Quando analisa-se os anos de estudo da população, as pessoas com deficiência estão abaixo da proporção da média da população total. Ao avaliar o percentual de pessoas que completaram 8 anos de estudo, por exemplo, encontra-se cerca de $2,7 \%$ do total de PCD, enquanto o índice entre a população total chega a 5,6\% (BELTRÃO; BRUNSTEIN, 2009).

$\mathrm{O}$ acesso à educação representa uma das principais iniciativas para a inclusão e um grande desafio a ser superado. No Brasil, devido 
às oportunidades de estudo estarem relacionadas às condições de renda, as PCD sempre estiveram em posição de desvantagem em relação ao restante da população. Também existem outras barreiras, como dificuldades de acessibilidade, severidade da deficiência e protecionismo da família, além do preconceito, discriminação e estigma, que fazem parte do cotidiano dessas pessoas e podem influenciar o interesse e a disposição para a escolarização (BELTRÃO; BRUNSTEIN, 2012).

Segundo Giordano (2000), a inserção profissional de Pessoas com Deficiências pode ocorrer em quatro modalidades: em função do tipo de deficiência, do grau, do nível de autonomia do sujeito e da natureza do posto de trabalho ou função a ser exercida.

A primeira, denominada "trabalho plenamente integrado", é quando o sujeito não precisa de adaptações no ambiente de trabalho. Na segunda, "trabalho integrado", há necessidade de algumas adaptações, que podem ser de caráter temporário ou permanente. A terceira modalidade abrange as chamadas "oficinas pedagógicas, abrigadas ou protegidas": programas de habilitação profissional realizados em instituições especializadas nos quais Pessoas com Deficiência aprendem atividades laborais, porém, de forma descontextualizada da realidade do mundo do trabalho. A última modalidade é o "trabalho domiciliar", desenvolvido na residência do sujeito, frequentemente intermediado por profissionais especialistas (GIORDANO, 2000).

\section{Leis no Brasil}

Em 24 de julho de 1991, o governo brasileiro sancionou a Lei $n^{\circ}$ 8.213/1991, a primeira Lei de Cotas para Pessoas com Deficiência no Brasil. No artigo 93, o governo obriga empresas com cem ou mais funcionários a preencher de $2 \%$ a $5 \%$ dos seus cargos com beneficiários reabilitados ou pessoas portadoras de deficiência, na seguinte proporção:

I. até 200 empregados: $2 \%$

II. de 201 a 500: $3 \%$

III. de 501 a 1.000: $4 \%$

IV. de 1.001 em diante: 5\%

(BRASIL, 1991) 
As fiscalizações para o cumprimento da lei nas empresas acontecem mensalmente pelo Ministério do Trabalho. No caso de multa, é estabelecido um teto para a penalidade, calculada com base no número de dias que a empresa esteve abaixo do mínimo de funcionários com deficiência exigido pela lei. Os valores cobrados por dia, no caso de descumprimento da Lei de Cotas, de acordo com a Portaria Interministerial - MTPS/MF $\mathrm{n}^{\circ} 1$, de 8 de janeiro de 2016, são:

I. De $\mathrm{R} \$ 2.143,04$ a $\mathrm{R} \$ 2.571,65$ para empresas de 100 a 200 empregados;

II. De R $\$ 2.571,65$ a R \$ 2.785,95 para empresas de 201 a 500 empregados;

III. De $\mathrm{R} \$ 2.785,95$ a $\mathrm{R} \$ 3.000,25$ para empresas de 501 a 1000 empregados;

IV. De $\mathrm{R} \$ 3.000,25$ a $\mathrm{R} \$ 3.214,55$ para empresas com mais 1000 empregados.

Nota: De acordo com essa portaria, o valor máximo que a multa pode chegar é de R $\$ 214.301 .536,00$ (PEZARINI, 2019).

Em 6 de julho de 2015, a então presidente da República Dilma Rousseff sancionou a lei $n^{\circ}$ 13.146/2015, conhecida como Lei Brasileira de Inclusão da Pessoa com Deficiência ou Estatuto da Pessoa com Deficiência. A matéria foi destinada a "assegurar e a promover, em condições de igualdade, o exercício dos direitos e das liberdades fundamentais por pessoa com deficiência, visando à sua inclusão social e cidadania" (BRASIL, 2015). Essa lei garante o acesso universal e igualitário à saúde para Pessoas com Deficiência por meio do SUS, oferece tecnologias assistivas que ampliam as habilidades dos estudantes nas escolas, garantem o acesso à educação superior e à educação profissional e tecnológica, assegura o direito ao trabalho em ambientes acessíveis e inclusivos em igualdade de oportunidades com as demais pessoas, entre outros (BOGAS, 2017).

Não há um valor específico de multa caso haja alguma irregularidade em relação à lei de 2015. O juiz deverá analisar e estabelecer o valor que a empresa deve pagar.

A obrigatoriedade imposta pelo governo quanto ao preenchimento de vagas para PCD desencadeou, por outro lado, um problema estrutural de falta de profissionais qualificados para ocupar os postos de trabalho. Como essas pessoas foram excluídas durante muito tempo do sistema produtivo, não houve ações institucionais coletivas para a 
capacitação desse grupo, tampouco condições sociais que motivassem PCD para um projeto de autodesenvolvimento. Os prejuízos não tardaram a surgir: as empresas começaram a fazer contratações desesperadas e malfeitas pela insuficiência de profissionais que possuem competências para o trabalho (BELTRÃO; BRUNSTEIN, 2012).

\section{Metodologia}

O caminho trilhado levou à adoção de uma metodologia de pesquisa de natureza qualitativa.

Para Minayo (2001), a pesquisa qualitativa trabalha com o universo de significados, motivos, aspirações, crenças, valores e atitudes, o que corresponde a um espaço mais profundo das relações, dos processos e dos fenômenos, que não podem ser reduzidos à operacionalização de variáveis. A pesquisa qualitativa não se preocupa com representatividade numérica, mas com o aprofundamento da compreensão de um grupo social, de uma organização, entre outros (GERHARDT; SILVEIRA, 2009).

Foi realizado um estudo de caso sobre a empresa Roche Diagnóstica Brasil por se tratar de uma companhia de grande porte da área farmacêutica, mundialmente reconhecida, para identificar a existência de política corporativa de inclusão.

Yin (2010) define o estudo de caso como uma pesquisa empírica, que investiga fenômenos contemporâneos dentro de um contexto de vida real. É utilizado especialmente quando os limites entre fenômeno e contexto são pouco evidentes. Atribui-lhe o objetivo de explorar, descrever e explicar o evento ou fornecer uma compreensão profunda do fenômeno.

Para a coleta de dados, foi realizada uma entrevista com a responsável pelas PCD no grupo de diversidade da empresa para a compreensão da política de inclusão da empresa. Posteriormente, foram feitas entrevistas com cinco funcionários com deficiência, com o intuito de compreender, em especial, o processo de contratação dessas pessoas, as áreas de atuação e suas expectativas na empresa. 


\section{Inclusão de pcd na roche}

A Roche

O Grupo Roche foi fundado em 1896, na Suíça, por Fritz Hoffmann-La Roche e está presente em mais de 150 países.

A Roche está transformando as práticas de laboratório por meio de investimento em pesquisa e desenvolvimento combinado com medicamentos, testes e medicamentos diferenciados e através de fluxos de trabalho e tecnologias conectadas.

Em 2015, a empresa possuía 97,1 mil funcionários, e faturamento de aproximadamente 166 bilhões de reais, sendo que $20 \%$ do faturamento anual é investido em pesquisa e desenvolvimento para novas soluções em diagnóstico e tratamento.

A companhia oferece diversos benefícios para os funcionários, como vale-transporte, convênios médico e odontológico, possibilidade de comprar ações da empresa com desconto e restaurante no local.

\section{Perfil dos entrevistados}

Foram realizadas seis entrevistas. A Entrevistada 1é a pessoa responsável pelas PCD no grupo de diversidade da empresa. Na Tabela 1, podemos verificar cargo, formação e tipo de deficiência dos Entrevistados 2, 3, 4, 5 e 6.

Dados do IBGE para 2010 (IBGE EDUCA, 2019) indicaram que há mais Pessoas com Deficiência visual e motora, o que se confirma entre os entrevistados neste estudo. Também podemos perceber que a empresa consegue receber diferentes tipos de deficiência.

Tabela 1. Perfil dos entrevistados

\begin{tabular}{|l|l|l|c|}
\hline Entrevistado & \multicolumn{1}{|c|}{ Cargo } & \multicolumn{1}{c|}{ Formação } & $\begin{array}{c}\text { Tipo de } \\
\text { Deficiência }\end{array}$ \\
\hline Entrevistado 2 & Assistente de Diretoria Jr. & Administração & Neurológica \\
\hline Entrevistado 3 & Assistente Administrativo & Administração & Motora \\
\hline Entrevistado 4 & Analista de Eventos Jr. & Farmácia & Visual \\
\hline Entrevistado 5 & Analista de Assuntos Científicos Jr. & Marketing & Visual \\
\hline Entrevistada 6 & Analista de RH Sr. & Psicologia e Coach & Motora \\
\hline
\end{tabular}

Fonte: Elaborada pela autora. 


\section{Acesso à divulgação das vagas}

Na empresa, conforme a Entrevistada 1, não há uma política específica de inclusão. Somente seguem a Lei de Cotas do governo brasileiro, que pelo porte da companhia, é de 5\% (BRASIL, 1991). Porém, a empresa está acima da cota mínima: pela lei, é obrigatório haver 58 PCD, e hoje são 62 PCD trabalhando na Roche, desde cargos mais baixos a cargos altos.

Uma empresa de consultoria externa auxilia na busca de Pessoas com Deficiência principalmente para cargos mais seniores, pois, segundo a entrevistada, há muita dificuldade para encontrar PCD para os cargos disponibilizados. Uma das justificativas é o fato de as pessoas não quererem mencionar ter algum tipo de deficiência por causa do preconceito que podem sofrer, também por terem receio de que sua deficiência não se enquadre nos "requisitos" da lei.

Dois entrevistados afirmaram que tiveram acesso às vagas através de uma agência chamada ISocial'; um entrevistado relatou ter tido acesso à vaga por meio de uma agência de empregos para PCD; outro encontrou a vaga pela plataforma LinkedIn; e um através de um site de vagas de emprego.

Apesar de existirem várias oportunidades para PCD em sites de busca de emprego, a Entrevistada 1 relata que não há tanta procura, não pela falta de qualificação das pessoas, mas sim por conta da desinformação. Por terem ainda que apresentar um laudo médico com a Classificação Internacional de Doença (CID), as pessoas ficam receosas de que suas deficiências não se enquadrem na vaga, e há ainda o receio de sofrer algum tipo de preconceito na empresa.

\section{Motivos de escolha da empresa}

O Entrevistado 5 escolheu a Roche por ser uma companhia na lista das melhores empresas para trabalhar no Brasil e, juntamente com o

1 Consultoria com foco em inclusão social e econômica de Pessoas com Deficiência no mercado de trabalho. Disponível em: https://bit.ly/2DpYnJF. Acesso em: 3 set. 2020. 
Entrevistado 4, por enxergar oportunidade de crescimento (além dos benefícios). O Entrevistado 3 se identificou com a vaga, então optou pela empresa. O Entrevistado 2 escolheu a empresa por ter uma indicação dentro dela, e a Entrevistada 6 relatou o motivo da escolha:

Voltar para o segmento da saúde era meu objetivo. A Roche sempre esteve em meu trajeto e sem dúvida no meu dia a dia, pois trabalho em RH, contratando pessoas. Ouvia muito sobre a empresa, sobre clima, possibilidade de desenvolvimento. Tudo isso, atrelado ao meu objetivo pessoal, fizeram com que eu me candidatasse.

Vantagens e desvantagens da Roche com relação a outras empresas

Dos cinco entrevistados, somente a Entrevistada 6 já trabalhou como PCD em outra empresa. Segundo ela:

A Roche me acolheu de uma forma incrível. A minha perda de mobilidade foi evoluindo, então eu também precisei me adaptar ao longo dos anos. Quando cheguei aqui, vi que o banheiro teve a porta alterada, tinha uma mesa preparada para receber uma cadeirante, as pessoas do time já estavam prontas para receber alguém na minha condição. Me senti acolhida e acima de tudo respeitada.

Para a Entrevistada 1, algumas PCD não declaram ter algum tipo de deficiência por medo de preconceito e até mesmo preconceito próprio. Conforme relatou:

Algumas pessoas que eu já escutei falarem que são PCD e que não dizem, porque existem empresas que fazem uma diferenciação. As empresas tratam de forma diferente ou elas (as pessoas) se sentem com receio de serem tratadas diferentes. Então elas não falam. Já escutei isso até de profissionais que declararam aqui ser PCD, mas que não queriam falar em função disso, não queriam entrar na Lei da Cota em função disso. 
Área de atuação e função dentro da empresa

Segundo a Entrevistada 1, na empresa, existem funcionários com deficiência em cargos administrativos, tecnologia da informação, acesso, recursos humanos e a nível gerencial na área médica. Porém, enfatizou a dificuldade de localizar no mercado Pessoas com Deficiência para cargos hierárquicos mais altos. Há vagas específicas para $\mathrm{PCD}$, porém se existem outras vagas (não necessariamente para esse grupo) e surge algum candidato com deficiência, a pessoa irá concorrer normalmente para a vaga. Ou seja, ser PCD não impede de concorrer para qualquer tipo de vaga.

Os entrevistados atuam nas áreas administrativas (Entrevistado 2 e 3), área farmacêutica (Entrevistado 4), de eventos (Entrevistado 5) e a Entrevistada 6, na área de recursos humanos. As funções são: assistente de diretoria júnior (Entrevistado 2), planejamento de manutenção preventiva e sistema de informação (Entrevistado 3), analista de assuntos científicos (Entrevistado 4), analista de eventos (Entrevistado 5) e analista de recursos humanos sênior (Entrevistada 6).

\section{Processo de contratação e treinamentos da empresa}

Para dois entrevistados, o processo das etapas de contratação foi demorado. Três entrevistados relataram que passaram por duas etapas, uma com recursos humanos e outra com os gestores da área. A Entrevistada 1 disse que o processo foi excelente.

Com relação aos treinamentos, a Entrevistada 1 relatou que não há treinamento diferenciado para PCD, a não ser os treinamentos básicos que são dados para todos os funcionários, específicos para os cargos. Não há diferenciação na empresa com qualquer pessoa. Segundo ela:

Hoje temos cargos mais administrativos e acabamos desenvolvendo a pessoa, dependendo da característica da vaga, se ela for uma vaga muito específica. 


\section{Adaptação na empresa}

Somente o Entrevistado 4 relatou dificuldade com a adaptação da empresa, porém isso seria mais pelo fato de sua área ser nova na companhia do que por algum problema da Roche:

Por estar num segmento totalmente diferente do mercado diagnóstico, foi desafiadora a parte de treinamentos e integração com as soluções da empresa, devido a minha área ser muito nova e não ter a estrutura adequada para esse momento inicial.

A Entrevistada 1 citou um exemplo no qual a empresa teve que agir para receber um de seus funcionários com deficiência:

Nós temos uma profissional em Acesso que tem nanismo, então tivemos que fazer uma adaptação para ela. Dependendo da necessidade, a gente vai enquadrar.

Várias atividades são realizadas ao longo do ano para conscientizar os funcionários, como a Semana da Diversidade. São eventos que trazem dados atualizados sobre os assuntos, bate-papos com pessoas que são deficientes para contar suas histórias e experiências e onde são ouvidas sugestões e reclamações para melhorar cada vez mais o ambiente de trabalho.

\section{Sugestões de ações que a empresa poderia adotar}

Dois entrevistados relataram que a empresa já adota ações, porém o Entrevistado 4 relatou o seguinte problema e sugeriu:

Creio que conscientizar os gestores da importância dessa iniciativa e não a encarar apenas como uma forma de incentivo fiscal. Também evidenciar os cases de sucesso que a empresa possui. 
A Entrevistada 6 também aborda a necessidade de conscientização:

A inclusão é um processo contínuo e que sofre alterações na medida em que o quadro de funcionários também muda. O que acredito que precisa ser feito é uma conscientização constante, não deixar o tema 'morrer'.

A Entrevistada 1 informou que, na empresa, foi criado um Grupo de Diversidade com diversos braços: negros, LBGT+, PCD. No grupo de PCD há nove integrantes, sendo cinco de fato Pessoas com Deficiência. Porém, o grupo é novo e ainda estão definindo frentes, metas e perspectivas. A Entrevistada 1 está muito otimista com esse projeto e com os outros braços do Grupo, que podem melhorar ainda mais esse processo de inclusão, mudar a cabeça de gestores e ouvir mais as sugestões e reclamações das PCD.

O Entrevistado 5 também sugeriu melhorias nas contratações:

Analisar o perfil dos candidatos PCD com novas estratégias no processo de contratação, conhecendo melhor o seu lado pessoal e potenciais, para direcionar as oportunidades de vagas a que o candidato possa agregar mais valor.

\section{Perspectivas de carreira}

Dos cinco entrevistados, apenas um relatou não ter muitas perspectivas na empresa, pois vê a estrutura da empresa bem desenhada. Para ele:

As PCD são sempre assistentes, e já vi casos aqui na empresa que o gestor teve que 'brigar' para que o mesmo fosse promovido para analista, mas se o gestor não for para cima do RH, fica anos como assistente e muitas vezes fazendo a função de analista.

Em contrapartida, outros três entrevistados veem oportunidade na empresa. O Entrevistado 4 pretende se tornar um MSL, ou Monitor 
de Pesquisa Clínica; o Entrevistado 5 deseja atuar na área comercial, representar a Roche na área de vendas, além de contribuir com suas habilidades para conquistar a confiança do cliente; e a Entrevistada 6 relatou:

Não sou vista simplesmente como alguém que cumpre uma cota. Sou uma profissional do time Roche, envolvida em processos e projetos desafiadores. Eu tenho uma deficiência, não sou uma deficiência e aqui tenho respeito com relação a isso. Desta forma, minha carreira é vista, recebo feedbacks constantes (peço também), procuro estudar para crescer e assumir outras posições.

Percebe-se que os funcionários têm oportunidades de crescimento na empresa, são reconhecidos.

\section{Estrutura física da empresa}

Somente um entrevistado acha que a estrutura física da empresa não é adequada para PCD, porém não especificou em quais aspectos há problemas. Já os outros quatro relataram que a estrutura é adequada sim, mas que deve sempre estar melhorando e adaptando para os diferentes tipos de deficiência.

O Entrevistado 5 menciona que a infraestrutura deve acompanhar a necessidade da PCD:

Hoje, em outras empresas, existem PCD que não encontramos na Roche, como exemplo, com deficiência auditiva, que precisam de profissionais com comunicação em libras.

Na empresa, há rampas nas entradas para cadeirantes ou pessoas com outros tipos de deficiência de mobilidade. Também foram instalados elevadores nos dois prédios, além de um banheiro adaptado para funcionário cadeirante. 


\section{Comentários das PCD}

O Entrevistado 4 fez o seguinte comentário:

Acho que seria de extrema importância que fosse feita uma ação de educação da liderança em relação ao tema, porque já ouvi alguns comentários desdenhosos sobre a validade da minha permanência no quadro de PCD porque meu caso (que é de deficiência visual unilateral) seria "simples".

A Entrevistada 6 elogiou a empresa:

Gosto muito daqui. Sinto que tenho autonomia e liberdade para ser quem sou, trazendo minhas contribuições.

\section{Considerações finais}

O objetivo do trabalho era contribuir para a formulação de novas políticas de inclusão, tanto para empresas do ramo farmacêutico quanto para outras empresas, com foco nas Pessoas com Deficiência. Através da pesquisa, foi possível compreender os pontos positivos, os que podem ser aprimorados e as perspectivas que as PCD que trabaIham na empresa têm para o futuro profissional.

Percebe-se que a empresa Roche, apesar de não ter uma política de inclusão específica e diferente da Lei de Cotas, está ciente da necessidade de atenção ao tema em seu dia a dia. A empresa tem buscado através de um Grupo de Diversidade ouvir as Pessoas com Deficiência e também os outros braços que dele participam (negros e LBGT+) para tornar a inclusão dentro da empresa algo natural, que possa trazer mais diversidade, mais ideias positivas e que o ambiente se torne agradável para todos.

Além do Grupo de Diversidade, a Roche conta com o auxílio de uma consultoria externa para trazer funcionários PCD para cargos mais altos, dando oportunidade em todos os seus níveis hierárquicos e em diferentes áreas. Esse é um ponto muito positivo visualizado durante o estudo. 
Através da pesquisa qualitativa com alguns funcionários da empresa, foi possível perceber que a companhia consegue receber pessoas com diferentes tipos de deficiência e está sempre melhorando sua estrutura física para facilitar a adaptação de todos.

Alguns pontos podem melhorar, como desenvolver um trabalho com gestores para conscientizar ainda mais sobre o papel de cada funcionário, independentemente de ser PCD ou não, para que também os desse grupo tenham a chance de se desenvolver e crescer dentro da empresa.

No Brasil, existem leis e outros regulamentos que asseguram e promovem, em condições de igualdade, o exercício dos direitos e das liberdades fundamentais para a pessoa com deficiência - visando a inclusão social e cidadania. A Lei de Cotas é de fundamental importância para garantir um trabalho digno para PCD.

As pessoas estão mudando sua forma de pensar e agir, mas o preconceito, infelizmente, ainda existe. As empresas devem cada vez mais realizar atividades, workshops e treinamentos (principalmente para gestores) para conscientizar os funcionários quanto à diversidade, pois empresas com essa mentalidade tornam-se referência no mercado, são mais criativas e o ambiente de trabalho torna-se muito mais agradável e produtivo para todos.

\section{Referências bibliográficas}

ABDALA, Vitor. Taxa de desemprego no Brasil cai para 11,8\% em julho, diz IBGE. Agência Brasil, Rio de Janeiro, 30 ago. 2019. Disponível em: https://bit.ly/3jlMdeD. Acesso em: 1 set. 2019.

BELTRÃO, Danielle Cristine; BRUNSTEIN, Janette. Reconhecimento e construção da competência da pessoa com deficiência em debate. Revista de Administração, [s.l.], v. 47, n. 1, p. 7-21, 2012. Business Department, School of Economics, Business \& Accounting USP. Disponível em: https://bit.ly/2F0iK0m. Acesso em: 2 set. 2020.

BOGAS, João Vitor. Estatuto da Pessoa com Deficiência: o que é e o que representa na luta pela Inclusão. Hand Talk, [S. I.], 30 nov. 2017. Disponível em: https://bit.ly/31S2pUP. Acesso em: 15 set. 2019. 
BRASIL. Lei No 8.213, de 24 de Julho de 1991. Dispõe sobre os Planos de Benefícios da Previdência Social e dá outras providências. Brasília, DF [1991]. Disponível em: https://bit.ly/31PDnp7. Acesso em: 15 set. 2019. BRASIL. Lei No 13.146, de 6 de Julho de 2015. Institui a Lei Brasileira de Inclusão da Pessoa com Deficiência (Estatuto da Pessoa com Deficiência). Brasília, DF [2015]. Disponível em: https://bit.ly/31RWdfm. Acesso em: 15 set. 2019.

BRASIL. Portaria interministerial MTPS / MF $n^{\circ}$ 1, de 8 de janeiro de 2016. Dispõe sobre o reajuste dos benefícios pagos pelo INSS e dos demais valores constantes do Regulamento da Previdência Social. Diário Oficial da União: seção 1, Brasília, DF, ano 152, p. 67-68, 11 jan. 2016.

BUENO, Janaína Maria; FREITAS, Maria Ester de. Representações sociais no contexto intercultural: o cotidiano de três subsidiárias brasileiras. Cad. EBAPE.BR, Rio de Janeiro, v. 16, n. 1, p. 101-118, jan. 2018. Disponível em: https://bit.ly/2QQKelJ. Acesso em: 15 out. 2019.

CAMARGO, Eder Pires de. Inclusão social, educação inclusiva e educação especial: enlaces e desenlaces. Ciênc. educ. (Bauru), Bauru, v. 23, n. 1, p. 1-6, mar. 2017.

COMO É a aceitação de pessoas com deficiência no mercado de trabalho? Freedom, Pelotas, 4 maio 2017. Disponível em: https://bit. ly/3hTMKtA. Acesso em: 15 set. 2019.

COSTILLA, Hessia Guillermo; NERI, Marcelo Cortes; CARVALHO, Alexandre Pinto de. Política de cotas e Inclusão Trabalhista das Pessoas com Deficiência. Ensaios Econômicos, Rio de Janeiro, n. 462, nov. 2002. Disponível em: https://bit.ly/3gTEmZy. Acesso em: 2 set. 2020. GERHARDT, Tatiana Engel; SILVEIRA, Denise Tolfo (org.). Métodos de Pesquisa. Porto Alegre: Editora da UFRGS, 2009. Disponível em: https://bit.ly/3hRFM8k. Acesso em: 17 out. 2019.

GIORDANO, Blanche Warzée. (D)eficiência e trabalho: analisando suas representações. São Paulo: Annablume; Fapesp, 2000.

IBGE EDUCA. Conheça o Brasil - População: pessoas com deficiência. 1 fev. 2019. Disponível em: https://bit.ly/2Gg4Esq. Acesso em: 23 set. 2019.

MATRÍCULAS de alunos com deficiência representam menos de $0,5 \%$ do total. Revista Ensino Superior, São Paulo, 24 jan. 2018. Disponível em: https://bit.ly/3olWaWK. Acesso em: 5 nov. 2020. 
MINAYO, Maria Cecília de Souza (org.). Pesquisa social: teoria, método e criatividade. Petrópolis: Vozes, 2001.

PESSOA com deficiência: a evolução do termo e dos conceitos aplicados. Freedom, Pelotas, 9 out. 2017. Disponível em: https://bit. ly/3blASOp. Acesso em: 18 ago. 2019.

PEZARINI, Mari. Falta de acessibilidade nas empresas: o barato que pode sair caro! Hand Talk, [S. I.], 12 abr. 2017. Disponível em: https://bit. ly/2F23KPz. Acesso em: 15 set. 2019.

SCARANO, Renan Costa Valle et al. Direitos Humanos e Diversidade. Porto Alegre: Sagah, 2018.

SPINIELI, André Luiz Pereira. Mas afinal o que é inclusão social? Justificando, São Paulo, 13 ago. 2018. Disponível em: https://bit.ly/2ER7wf7. Acesso em: 18 ago. 2019.

YIN, Robert K. Estudo de caso: planejamento e métodos. $4^{\mathrm{a}} \mathrm{ed}$. Porto Alegre: Bookman, 2010. 



\title{
Tecnologia móvel digital para pessoas idosas
}

\author{
Luan Alves Monteiro \\ Fernanda Contarelli Lima \\ Roberto Sanches Padula
}

\begin{abstract}
Resumo
As tecnologias revolucionaram os hábitos, costumes e a maneira de viver de diferentes pessoas em diversas épocas; talvez as que causaram maiores impactos tenham sido as da informação e comunicação (TIC), principalmente por meio da tecnologia móvel digital e da internet. O número de internautas com 60 anos ou mais (idosos) só cresce no Brasil e isso tende a continuar, tanto pelo aumento da população nessa faixa etária quanto pela maior adesão desses às tecnologias. Sugere-se que as TIC possam ser importantes fontes de apoio para ajudar na inclusão social e no envelhecimento saudável e participativo desse grupo na sociedade e até mesmo em círculos menores, como a própria família. Esta pesquisa busca verificar as possibilidades criadas por aplicativos das plataformas Android e IOS desenvolvidos para idosos. Para isso, foram realizados mapeamento e pesquisas de campo, buscando compreender possíveis necessidades, dificuldades e a utilização dos apps pelo público sênior. Os dados coletados demonstram que o uso dos aparelhos celulares pelos idosos se dá em aplicações mais simples, como ligações, ouvir músicas, mandar mensagens, entre outras, e que esse público apresenta algumas dificuldades para manusear os aparelhos, principalmente relacionadas à baixa usabilidade e configurações. É indiscutível o potencial das tecnologias como importantes ferramentas de apoio e suporte para grupos vulneráveis; no entanto, nota-se que os apps sociais são poucos usados e conhecidos por eles e seus familiares. Destaca-se que os aplicativos desenvolvidos para o público em geral, por exemplo os de
\end{abstract}


comunicação e sociais (como WhatsApp e Facebook), de transporte (como Uber e 99App), de mobilidade (como Waze e Google Maps), de compras, bancos, entre outros são mais utilizados e os ajudam a realizar parte de suas ações e tarefas rotineiras ou as simplificam.

Palavras chaves: Idosos. Tecnologia móvel. Smartphones. Celulares. Aplicativos.

\section{Introdução}

A tecnologia móvel digital, por conta da popularização dos smartphones e da internet, pode integrar os usuários, pois são instrumentos de pertença social, ou, na sua falta, pode manter os sujeitos à margem da sociedade. Os aplicativos sociais, na maioria gratuitos, demonstram potencial inigualável para o auxílio, aprendizado e convívio social de pessoas idosas ou com deficiência e de cuidadores, apresentando potencial associativo de maneira colaborativa, criativa e inédita da relação entre o cidadão e a sociedade.

Com isso em mente, podemos ressaltar como a tecnologia no mundo contemporâneo tem potencial para aprimorar a qualidade de vida e o convívio social para aqueles que são parte de camadas vulneráveis da sociedade. A criação de aplicativos para tal público mostra mais um avanço histórico para a inclusão social.

Hoje, verifica-se que há pouca pesquisa sobre o uso de aplicativos de celular para pessoas vulneráveis, sejam elas idosos, deficientes físicos, cegos etc. Dessa forma, este projeto pretende responder ao seguinte problema de pesquisa: os apps desenvolvidos para os idosos criam possibilidades para seus usuários de forma a melhorar sua inclusão social?

Portanto, este estudo pauta-se em um objetivo principal - discutir e provocar a reflexão de como a tecnologia móvel pode ajudar a reinserir o público sênior na comunidade de forma ativa ou participativa - e tem como objetivos específicos pesquisar se há bons aplicativos disponíveis no mercado, se os idosos os usam ou não e por quais motivos, buscando entender melhor as necessidades do nosso público-alvo e as principais dificuldades no uso dos celulares smartphones. 


\section{Objetivos}

\section{Objetivos gerais}

Verificar as possibilidades criadas pelos apps desenvolvidos para os idosos.

\section{Objetivos específicos}

- Inventariar apps sociais delineados para idosos e deficientes físicos e discorrer sobre seu perfil, utilidade e destino;

- Compreender quais são as principais dificuldades no uso da tecnologia móvel pelos idosos e quais são as principais utilidades;

- Verificar o uso dos apps sociais na rotina dos idosos.

\section{Revisão da literatura}

\section{Os idosos no mundo e no Brasil}

Atualmente, a maioria das crianças e jovens conforme crescem e se desenvolvem vão se conectando mais cedo com a tecnologia e seus aparatos, logo, a aprendizagem ocorre de maneira natural e segura. Mas neste momento, existe um grupo com maiores dificuldades de adaptação a essas novas tecnologias, pois precisaram passar por um processo acelerado de aprendizagem: os idosos.

Segundo a Organização das Nações Unidas (ONU), “[o] mundo está no centro de uma transição do processo demográfico única e irreversível que irá resultar em mais populações idosas em todos os lugares do mundo" (NAÇÕES UNIDAS, 2014). Em seu site, a entidade destaca o avanço da população idosa no planeta e a importância de todos os países estarem atentos e promovendo iniciativas para o envelhecimento seguro e saudável. Entre os dados mais interessantes apresentados estão 
que a população idosa vai crescer de cerca de 962 milhões em 2017 para 1,4 bilhão em 2030 e 2,1 bilhão em 2050, alcançando um quarto ou mais da população de todos os países do mundo, exceto no continente africano.

Comprovando esses dados, em reportagem recente divulgada pelo G1 com dados do Instituto Brasileiro de Geografia e Estatística (IBGE), constatou-se que a população brasileira está envelhecendo. Segundo as projeções realizadas pelo estudo, no ano de 2039, os idosos serão mais numerosos que a quantidade de crianças vivendo em nosso país e representarão, em 2060, um quarto da população brasileira, ou seja, a cada quatro brasileiros, um será idoso com mais de 69 anos de idade (ALVARENGA; BRITO, 2018). Essa inversão na pirâmide etária brasileira e de boa parte dos países do mundo é causada pelo aumento da expectativa de vida (com o avanço da medicina e a maior preocupação com o envelhecimento saudável) e pela redução da taxa de natalidade e fertilidade, que resultam no crescimento do topo da pirâmide e na diminuição de sua base (ver Figuras 1 e 2 sobre a pirâmide etária brasileira).

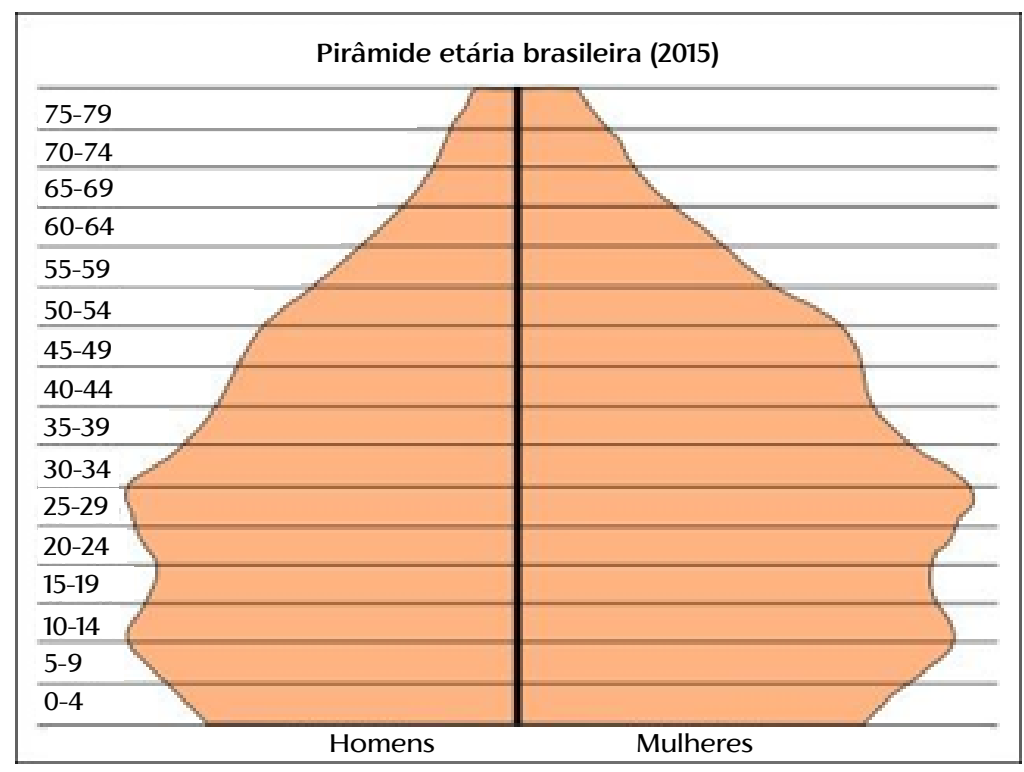

Figura 1. Pirâmide etária brasileira do ano de 2015 Fonte: Mundo educação/IBGE (2015). 


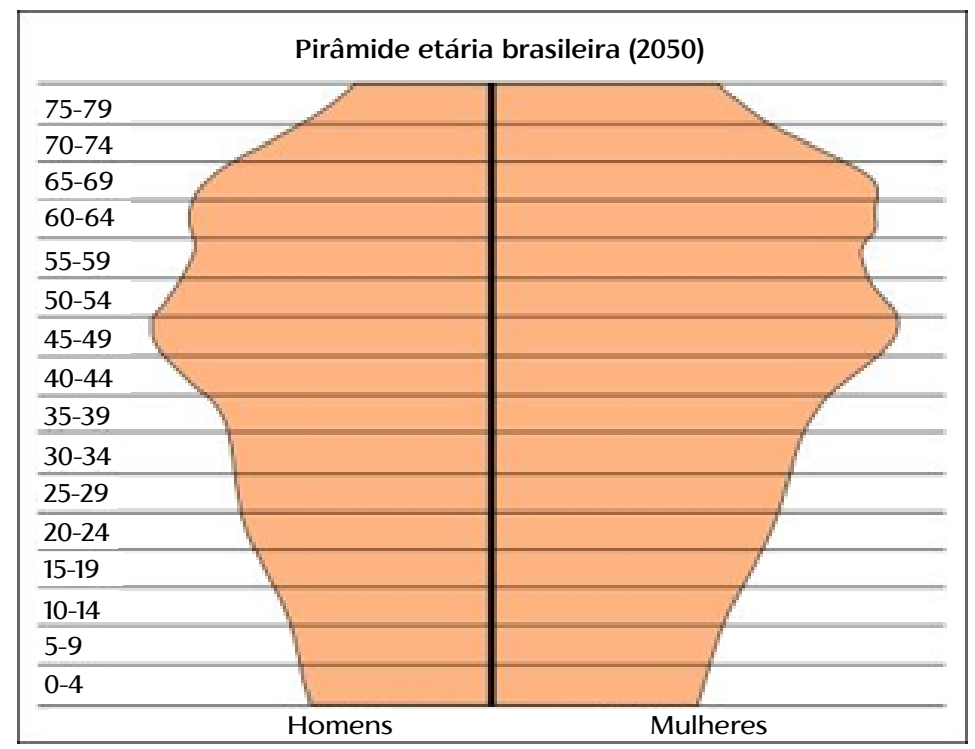

Figura 2. Pirâmide etária brasileira do ano de 2050

Fonte: Mundo educação/IBGE (2015).

Com todas essas informações, o envelhecimento da população brasileira não pode ser tratado como um problema para nosso país, e sim com certa naturalidade, já que como mostramos nas imagens acima, o perfil demográfico está em transição do adulto para o idoso até o ano de 2050. Assim, precisamos nos preparar para ter a capacidade de garantir os direitos dos idosos e manter a economia ativa e equilibrada, já que dentro desse cenário está a aposentadoria e teremos menores índices de mão de obra disponível.

Segundo o Estatuto do Idoso (BRASIL, 2003), assinado e sancionado pelo então Presidente da República, Luiz Inácio Lula da Silva, idoso é qualquer ser humano que tenha idade igual ou superior a sessenta anos de idade. O documento discorre sobre todos os direitos fundamentais inerentes à pessoa humana e, principalmente, busca garantir que a legislação direcionada ao idoso seja cumprida, concretizando o acesso à saúde, à alimentação, à educação, à cultura, ao esporte, ao lazer, ao trabalho, à cidadania, à liberdade, à dignidade, ao respeito e à convivência 
familiar e comunitária, sendo de responsabilidade da família, sociedade, comunidade e do poder público os assegurar.

Muitos outros textos discorrem sobre os direitos da população idosa no Brasil e no mundo, entre eles, vários feitos pela ONU - alguns dos diversos órgãos responsáveis por tratar desse tema na entidade são a Organização Mundial da Saúde (OMS) e o Fundo de População das Nações Unidas (UNFPA). Desses textos, muitos tiveram destaque internacional e foram de grande importância para o tema, como o Princípio das Nações Unidas em Favor das Pessoas Idosas (1991), que enumerou 18 direitos fundamentais dos idosos em relação a independência, participação, cuidado, autorrealização e dignidade, e o Plano de Ação Internacional de Madrid para o Envelhecimento (MIPAA), que tem o objetivo de facilitar e promover três principais áreas de atuação: pessoas idosas e desenvolvimento, promoção da saúde e bem-estar na velhice e criação de um ambiente de vida propício e favorável (NAÇÕES UNIDAS, 2014).

Entre os direitos destacados acima está a cidadania, que significa exercer os direitos e deveres civis, políticos e sociais estabelecidos na Constituição de seu país (SIGNIFICADOS, 2014). Mas os idosos são considerados e tratados ativamente como cidadãos ou são marginalizados pela nossa sociedade e vistos como um fardo que precisa ser carregado? Embora possamos seguir por esse caminho e discutir muito mais sobre a posição dos idosos na sociedade, esse não é o principal objetivo deste projeto, e sim compreender melhor como a tecnologia móvel, através dos aplicativos, ajuda ou poderia ajudar os idosos em suas rotinas.

Para isso, se tornou necessário o estudo e a revisão de vários conceitos, como envelhecimento, inclusão e exclusão digital e social e entre outros. A seguir, compreenderemos melhor alguns desses conceitos.

\section{Envelhecimento, um estágio da vida}

O termo envelhecimento refere-se a um "fenômeno biológico, psicológico e social que atinge o ser humano na plenitude da sua existência, modifica a sua relação com o tempo, o seu relacionamento com o mundo e com a sua própria história" (TEIXEIRA, 2006, p.1). 
Esse processo é progressivo e imutável, ou seja, "é um fenómeno inevitável, inerente à própria vida, equivalente à fase final de um programa de desenvolvimento e diferenciação" (SOUSA; FIGUEIREDO; CERQUEIRA, 2006, p. 21). Logo, a maioria dos seres humanos passaram ou irão passar pelo processo de envelhecimento, o que confirma o aumento das populações idosas no mundo.

Nesse sentido, vários autores sintetizam a importância da família, da sociedade, dos amigos e vizinhos para a inclusão e o envelhecimento de forma ativa e saudável dos idosos na sociedade, reduzindo o pensamento negativo de que esse processo só está relacionado com perdas. Um estudo apresentado no livro Velhice: Aspectos Biopsicossociais (ZIMERMAN, 2000) aponta que o ambiente familiar impacta de forma crucial como a pessoa idosa enfrentará as barreiras criadas nessa fase da vida. É indiscutível a existência dos danos desse processo ao corpo humano, já que podemos pensar nos sentidos mais afetados pelo avanço da idade, por exemplo, a dificuldade de enxergar, as perdas na audição (diminuição da captação de sons), no tato das mãos e dos pés, entre outros.

Ainda sobre esse assunto, é importante destacar que o idoso não sofre apenas mudanças físicas, mas também sociais e psicológicas, "alterações corporais, cognitivas e emocionais, expectativas sociais, relações interpessoais, alterações familiares, profissionais, na rede de relações e no próprio contexto de residência" (FONSECA, 2012, p. 96). Por isso, precisa adequar-se a elas e ao processo inevitável do avanço da idade. Para alguns autores, essa adaptação depende de vários fatores diferentes, como a capacidade de adaptação no passado, o estado de espírito, entre outros.

O envelhecimento ativo e saudável tornou-se importante para essa etapa da vida do ser humano e só é possível atingi-lo por meio do esforço de familiares, da comunidade, do governo e dos próprios idosos, que em conjunto, podem organizar projetos ou medidas capazes de manter o público sênior participativo, integrado à sociedade e com seus direitos e deveres garantidos, não somente na Constituição, mas na prática, em seu dia a dia. Pois "uma sociedade para todas as idades possui metas para dar aos idosos a oportunidade de continuar contribuindo com a sociedade. Para trabalhar neste sentido é necessário remover tudo que representa exclusão e discriminação contra eles" (UNITED NATIONS, 2002, p. 19-20; NAÇÕES UNIDAS, 2014). 


\section{A tecnologia e suas revoluções}

A palavra tecnologia tem origem no termo grego tekhne (técnica, arte ou ofício) junto com o sufixo logia, que tem como significado "estudo". Logo, tecnologia refere-se a um conjunto de métodos, instrumentos e técnicas que visam a resolução de problemas (SIGNIFICADOS, 2014).

O ser humano convive com revoluções tecnológicas por toda a sua existência. As primeiras delas vieram com as tecnologias primitivas, como a descoberta do fogo, a invenção da roda, a escrita e entre outras. Depois, vieram as tecnologias da época medieval, como as grandes embarcações e navegações que permitiram a expansão de diversos países e a descoberta e conquista de novos (expansão marítima). As tecnologias referentes à época da Revolução Industrial, como as grandes máquinas movidas a vapor, mudaram a forma de produção, elevando a outro patamar as indústrias da época, principalmente as inglesas e francesas. Já as tecnologias da informação e comunicação (também conhecidas como TIC) alteraram a forma como nos conectamos e nos comunicamos um com os outros, principalmente com o surgimento da internet e a popularização de aparelhos móveis, como os celulares.

Todas essas tecnologias alteraram comportamentos humanos e fez-se necessária a adaptação a um novo jeito de viver ou de fazer certas atividades, que em outras épocas eram realizadas de maneira totalmente diferente. Vejamos os exemplos a seguir.

Os alimentos ora comidos crus começaram a ser cozidos com a descoberta do fogo; o que antes era apenas vendido internamente por meio de trocas começou a ser negociado em vários lugares; surgiram produtos diferentes com as grandes embarcações e o que era produzido artesanalmente se transformou numa produção de massa padronizada com as novas tecnologias industriais e as teorias da administração científica, cunhadas por Taylor e desenvolvidas por Ford. Por fim, a comunicação feita através de cartas escritas deu espaço para os aplicativos de conversas instantâneas, com troca de dados ao mesmo instante, acesso a diversas informações com apenas alguns cliques e a conexão entre pessoas de diversos lugares do mundo por meio das TIC.

Hoje, vivemos à beira das revoluções tecnológicas da indústria 4.0, que promete novamente nos tirar da zona de conforto e causar grandes 
impactos, principalmente no mercado de trabalho e em nosso ambiente de maneira geral.

Podemos notar que o ser humano sempre resolveu problemas com novas criações que impactaram nossas formas de viver, costumes e rotinas, e por consequência indicaram a iminente necessidade de adaptação. Porém, certos grupos tiveram maiores dificuldades de se adaptar ao novo ambiente. Um exemplo claro dessa dificuldade é a alta taxa de desemprego em vários setores que vêm substituindo a mão de obra humana por máquinas, mais rápidas e eficientes. Várias pessoas estão ou ficaram por um bom tempo desempregadas porque não conseguiram recolocação profissional na mesma área ou não procuraram outra para se especializar, talvez, principalmente, por conta da falta de percepção sobre os processos de mudança causados pelas inovações tecnológicas.

Na era das TIC, a tecnologia móvel foi popularizada através de dois principais fatores: o primeiro é a criação e o desenvolvimento da internet até chegar ao formato e funcionamento que conhecemos hoje (infraestrutura), e o segundo é a criação e o desenvolvimento dos computadores e aparatos tecnológicos móveis, como notebooks, tablets e principalmente os celulares smartphones, sendo bastante acessíveis à população de maneira geral. É importante destacar que a falta de um ou desses dois fatores pode ocasionar a exclusão digital e impactar na sociabilidade. Por isso, é indispensável a facilitação do acesso a esses pelas populações mais carentes e vulneráveis, ou seja, com menor poder de compra e renda.

Dados de diversas fontes comprovam essas informações. Segundo o Centro Regional de Estudos para o Desenvolvimento da Sociedade da Informação (COMITÊ [...], 2018), no ano de 2018, cerca de 67\% dos domicílios do país acessavam a internet, sendo $62 \%$ através da banda larga fixa e $27 \%$ via conexão móvel. Os principais motivos apontados para a falta do acesso nos outros $33 \%$ são o alto custo (27\%), falta de domínio do uso da internet (18\%) e a falta de interesse (16\%). Também é importante destacar os diferentes perfis de usuários por regiões ou classe social: enquanto as classes $\mathrm{D} / \mathrm{E}$ e a região Norte acessam a internet majoritariamente pela banda larga móvel (respectivamente $47 \%$ e $46 \%$ ), por meio dos aparelhos celulares e modem 3G e 4G (resultado da popularização da rede móvel e das dificuldades de acesso à internet de 
banda fixa), as classes A, B, e C possuem altas porcentagens de banda larga fixa disponível em suas residências, respectivamente, $87 \%, 81 \%$ e $63 \%$. É importante, por fim, apontar também que a internet de banda larga fixa está presente em $63 \%$ da área urbana versus 51\% na área rural.

Uma pesquisa do IBGE divulgada em reportagem no portal G1 com dados referentes ao último trimestre de 2017 aponta que o número de residências com acesso à internet subiu para $75 \%$, atingindo na área rural $41 \%$ dos domicílios e nas áreas urbanas, $80 \%$ (SILVEIRA, 2018).

Outro dado interessante a ser destacado é a popularização do celular como forma de acesso à internet (COMITÊ [...], 2016). Em 2016, 93\% dos usuários utilizavam o aparelho para acessar a internet, já segundo o IBGE, esse número chegou a 98\% em 2017. Esse expressivo aumento resulta do crescimento de usuários idosos no país, já que dos novos 10 milhões de usuários de internet, 23\% tinham 60 anos ou mais. Para uma ilustração mais clara desse aumento, enquanto a população idosa no período correspondente cresceu em cerca de 1 milhão de pessoas, a de usuários de internet com 60 anos ou mais cresceu em 2,3 milhões de internautas. Vejamos o Gráfico 1:

Distribuição percentual dos internautas brasileiros por grupo etário Maioria das pessoas que acessam a internet no Brasil tem entre 25 e 39 anos

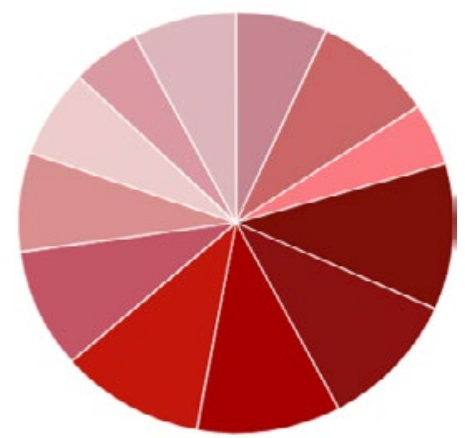

10 a 13 anos: $6,8 \%$

25 a 29 anos: $10,5 \%$

40 a 44 anos: $9,2 \%$

60 anos ou mais: $7,7 \%$

14 a 17 anos: $8,9 \%$

30 a 34 anos: $10,7 \%$

45 a 49 anos: $7,6 \%$

18 ou 19 anos: $4,8 \%$

35 a 39 anos: $10,7 \%$

50 a 54 anos: $6,8 \%$
20 a 24 anos: $11,2 \%$

55 a 59 anos: 5,1\%

Gráfico 1. Distribuição dos internautas brasileiros por faixa etária, com destaque para o crescimento de usuários idosos

Fonte: G1/IBGE (2018). 
No ano de 2017, o total de usuários era de 126,4 milhões. Desses, 7,7\% eram idosos, ou seja, aproximadamente 9,8 milhões, número que só tende a aumentar. Embora os dados apresentados anteriormente demonstrem o desenvolvimento da tecnologia móvel no Brasil, além do expressivo aumento no número de usuários idosos (sendo esse o grupo com maior crescimento de usuários), ainda são necessários estudos para melhor compreender o impacto da tecnologia e de seus aparatos na vida e na rotina do público sênior.

Fica evidente que as ferramentas tecnológicas podem servir como importantes fontes de apoio e suporte para pessoas dessa faixa etária. Segundo publicação das Nações Unidas, "[a] digitalização e as ferramentas tecnológicas podem servir como oportunidade para ajudá-las a manter ou fortalecer suas capacidades e permitir que vivam de maneira autônoma, independente e digna" (NAÇÕES UNIDAS, 2014). Para que todas essas oportunidades não se transformem em desafios provocados pela exclusão digital e pelas dificuldades de acesso a fatores primordiais, como internet e aparelhos móveis, é necessário foco para que haja democratização do acesso aos meios tecnológicos e suas ferramentas.

Uma questão presente em países subdesenvolvidos como o Brasil é a falha em programas de capacitação para o público da terceira idade se familiarizar com essas novas tecnologias, que poderiam fazer com que eles realmente conseguissem ter uma participação ativa e independente. A partir desse conhecimento básico sobre o funcionamento digital, ficaria consideravelmente mais fácil para pessoas da terceira idade conhecerem os aplicativos que já foram desenvolvidos para facilitar seu cotidiano e sua interação com a sociedade de forma geral.

Segundo Lemos,

A grande questão reside em como lidar com a exclusão digital existente no país, como o Brasil, que conta com altos índices de pobreza e analfabetismo. É certo que a pobreza e o analfabetismo se constituem como problemas que precisam ser sanados com urgência. Mesmo assim, não há como pensar a exclusão digital em segundo plano, visto que o desenvolvimento das tecnologias se dá 
cada vez mais rapidamente e o abismo existente entre incluídos e excluídos tende a aumentar. (LEMOS, 2007, p. 16)

Dessa forma, é inevitável destacar que a pobreza e o analfabetismo são fatores primordiais que afetam diretamente e contribuem para aumentar os números referentes à exclusão digital no país. Embora esses problemas sejam de grande urgência para serem sanados pelos órgãos públicos responsáveis, a exclusão digital não pode ser deixada de lado, ainda mais com a velocidade que essa área se transforma e inova. Pelo contrário, a tecnologia deve ser usada como uma importante ferramenta para diminuir esses índices e colaborar com oportunidades de crescimento profissional e pessoal, criando assim melhores perspectivas de renda, exercício de cidadania e uma nova visão social, desde que haja domínio das ferramentas pelos usuários (LEMOS, 2007, p. 16).

Segundo Sales, essas questões tornaram-se passíveis de discussão há muito tempo para especialistas da área de tecnologia:

As tecnologias da comunicação e da informação (TIC) têm estimulado alterações significativas na forma como as pessoas interagem, se comunicam, se conectam e se relacionam com o mundo real e virtual. Para alguns usuários, como, por exemplo, os idosos, as TIC podem se tornar uma barreira, considerando sua história de vida, escolaridade, cultura, linguagem, saúde etc. (SALES, 2014, p. 60)

Para Vázquez (2016), existe uma barreira digital que exclui aqueles que estão desconectados ou sem acesso a smartphones ou à internet, mas também uma barreira de conhecimento que exclui aqueles que não conseguem usar seus celulares para o desenvolvimento pessoal ou melhorar a qualidade de suas vidas.

Principais barreiras para uso das TIC

Uma das principais fontes que ajudaram e continuam a contribuir para a inclusão ou exclusão social nos últimos tempos têm sido 
as revoluções tecnológicas, ou seja, as novas tecnologias, com o surgimento de computadores pessoais, celulares, internet e outras inovações. Na era da tecnologia da informação e comunicação, as pessoas que não se adaptaram ou não tinham acesso a essas ferramentas por diversos motivos ficaram de certa forma marginalizadas em relação à rede de dados e a certos grupos da sociedade. Silveira destaca que

a exclusão digital impede que se reduza a exclusão social, uma vez que as principais atividades econômicas, governamentais e boa parte da produção cultural da sociedade vão migrando para a rede, sendo praticadas e divulgadas por meio da comunicação informacional. Estar fora da rede é ficar fora dos principais fluxos da informação. Desconhecer seus procedimentos básicos é amargar a nova ignorância. (SILVEIRA, 2001, p. 18)

A seguir, listamos os principais motivos que podem ocasionar a exclusão digital, segundo alguns autores:

- Alto custo da internet e dos aparelhos tecnológicos: o alto custo do acesso à internet, seja ela de banda larga ou fixa, além dos preços elevados dos aparelhos móveis e computadores, tornou-se uma barreira para o acesso das populações mais carentes, ou seja, com menor poder de compra e renda, embora hoje esses valores estejam cada vez mais acessíveis à população em geral;

- Nível de escolaridade: o baixo nível de escolaridade é um dos fatores que ajudam a separar os futuros possíveis usuários da internet e da tecnologia, seja por medo das dificuldades de aprendizagem ou pela falta de interesse em sua utilização;

- Aspectos socioculturais: refere-se à cultura de considerar a internet e a tecnologia como supérfluas e desnecessárias. Essa cultura vem se alterando com o passar do tempo, e já que agora a tecnologia faz parte de nossas vidas, talvez esses aspectos estejam mais enraizados nas pessoas de mais idade, que viveram a maior parte da sua vida sem o uso dessas ferramentas;

- Faixa etária: ainda existe uma grande dificuldade dos idosos na utilização da tecnologia e da internet. Muitos não sabem como 
utilizá-las, embora o número de idosos internautas esteja em constante crescimento, como já foi destacado;

- Usabilidade: esse termo refere-se à amigabilidade de uma interface, ou seja, se a plataforma é de fácil uso e manuseio para seus usuários. Aplicativos com boa usabilidade têm maiores chances de fazerem sucesso com o público em geral. Um exemplo seria o WhatsApp, utilizado em larga escala pela maioria das pessoas, independentemente de renda, sexo, idade ou grau de escolaridade.

Essas possíveis barreiras são as principais dificuldades encontradas pelos idosos (mas não somente por esse grupo etário) para conseguirem ter acesso à tecnologia, saber como utilizá-la e aproveitá-la de maneira produtiva, de forma que realmente gere ganhos para suas ações ou rotinas. Entre os principais impactos que o uso das TIC (principalmente as tecnologias móveis) pode causar na vida dos idosos, além dos já citados anteriormente, estão o poder de diminuir a relação de solidão e aumentar a participação ativa dos idosos na sociedade e em grupos menores, como a própria família, melhorando a sua autoestima e ajudando a combater um possível estado de depressão. Alguns estudos relatam que a inclusão digital levou à redução do sentimento de isolamento social e de solidão e de sintomas de depressão entre os usuários idosos (SALES, 2014, p. 63).

Contudo, a partir desse momento, começamos a pensar a tecnologia como um importante instrumento para ajudar na inclusão social, ou seja, como destacado no trecho acima, o uso da tecnologia pode impactar e ajudar a diminuir o sentimento de exclusão ou isolamento social e gerar ganhos importantes para grupos em situações mais vulneráveis, como os idosos. É ainda importante destacar que, para alguns autores, presumir que a simples inclusão digital será suficiente para colaborar com a inclusão social é de certa forma um erro, já que pode ser que ocorra inclusão digital, mas não haja impactos no âmbito social.

\section{Procedimentos metodológicos}

Este trabalho enquadra-se na área das Ciências Sociais e Aplicadas e se configura como uma pesquisa aplicada. Entre os 
procedimentos adotados para sua realização está uma pesquisa bibliográfica, que busca e seleciona, sintetiza e analisa materiais publicados entre o conhecimento científico acumulado sobre o problema. Este trabalho contém também um levantamento de dados primários em campo.

Entre os procedimentos utilizados para levantar os dados primários, destacamos:

- Inventário de apps sociais delineados para pessoas com deficiência e idosas lançados nos últimos 5 anos, pesquisados primeiramente em notícias na imprensa e nas bases para IOS e Android;

- Pesquisa na Google Play Store e App Store dos aplicativos desenvolvidos para o público sênior;

- Testes de alguns apps sociais de ambas as plataformas (Android e IOS), mapeando objetivos, funcionalidades etc.;

- Questionários, entrevistas, grupos focais e entrevistas em profundidade para entender as necessidades dos usuários do público-alvo, bem como a funcionalidade, usabilidade e ganhos reais na qualidade de vida e de interação social;

- O público-alvo que participou dos levantamentos de campo foi selecionado por meio de entidades assistenciais e instituições com as quais tenham algum tipo de vínculo. Participaram também pessoas próximas que se encaixassem no grupo pesquisado.

\section{Resultados das pesquisas de campo e análise}

Inventário dos aplicativos para idosos na Google Play Store e App Store

Os resultados apresentados a seguir focam nos aplicativos para idosos existentes nas lojas virtuais para aparelhos móveis (Google Play Store e App Store). Esse foi um dos primeiros passos para compreender melhor como são esses aplicativos e pelo que os idosos poderiam se interessar ou buscar neles. 
Tabela 1. Classificação dos aplicativos para idosos mapeados nas lojas virtuais da Google e da Apple

\begin{tabular}{|l|c|}
\hline Emergência & Categorias \\
\hline Interface/acessibilidade & 8 \\
\hline Cuidados médicos & 6 \\
\hline Informação & 11 \\
\hline Social/comunicação & 12 \\
\hline Educação & 4 \\
\hline Exercícios físicos & 4 \\
\hline Total & 1 \\
\hline
\end{tabular}

Fonte: Elaborado pelos autores (2019).
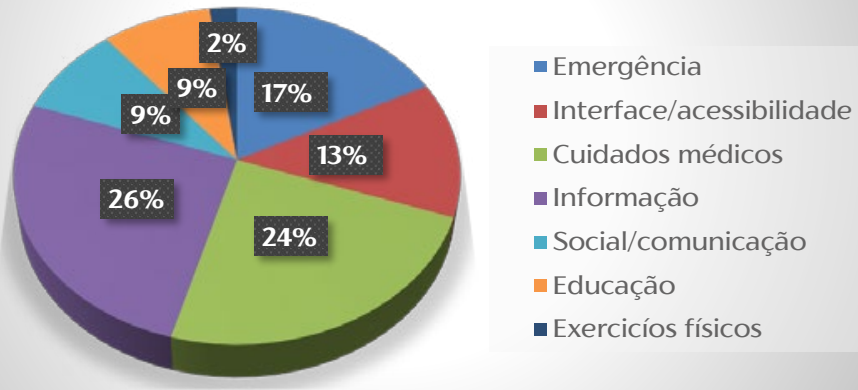

Gráfico 2. Distribuição percentual das categorias dos aplicativos para idosos mapeados nas lojas virtuais da Google e da Apple

Fonte: Elaborado pelos autores (2019).

\section{Pesquisa de campo com idosos}

A partir desses testes e dos resultados acima apresentados sobre os aplicativos especialmente voltados para os idosos, foi formulado um questionário semiestruturado com 12 questões que buscavam uma melhor compreensão do uso dos celulares pelos idosos e dos aplicativos que esses mais utilizam, ou que poderiam ajudá-los. 
Esse questionário foi aplicado a 36 idosos de diferentes lugares. Nos Gráficos de 3 a 14, vemos as perguntas e os resultados mais importantes dessa pesquisa:

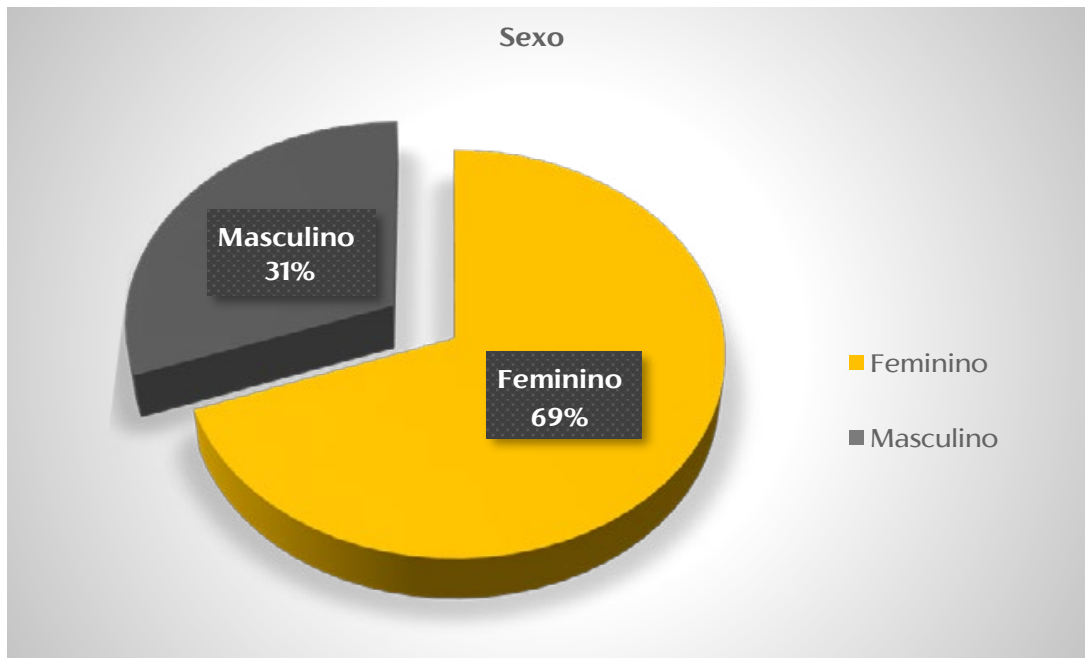

Gráfico 3. Distribuição percentual por sexo dos participantes da pesquisa de campo com idosos

Fonte: Elaborado pelos autores (2019).

IDADE

$\mathrm{N}^{\mathrm{a}} \mathrm{\Delta} \%$

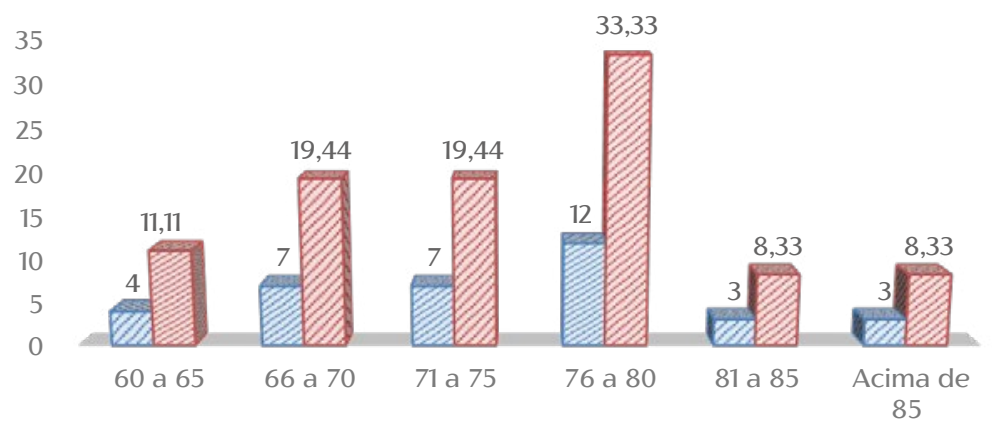

Gráfico 4. Distribuição por faixa etária dos participantes da pesquisa de campo com idosos

Fonte: Elaborado pelos autores (2019). 


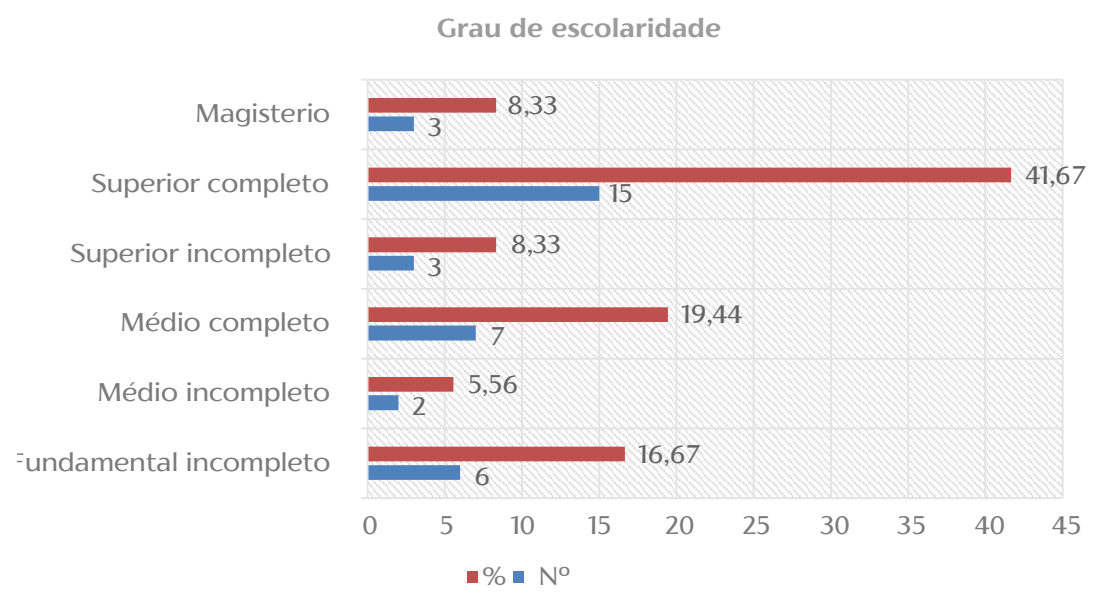

Gráfico 5. Distribuição por grau de escolaridade dos participantes da pesquisa de campo com idosos

Fonte: Elaborado pelos autores (2019).

RENDA

№ $\mathrm{N} \%$

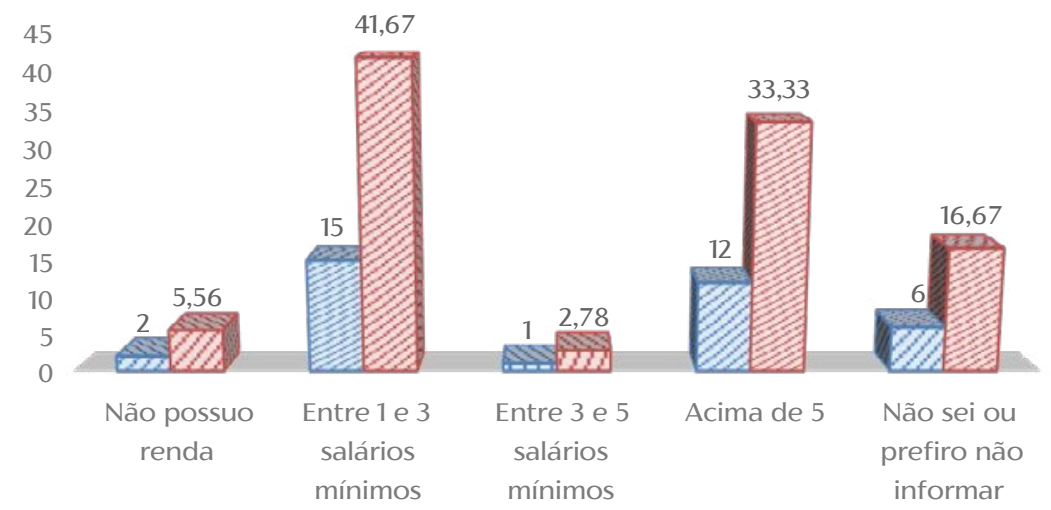

Gráfico 6. Distribuição por renda dos participantes da pesquisa de campo com idosos

Fonte: Elaborado pelos autores (2019). 
Dificuldades dos idosos

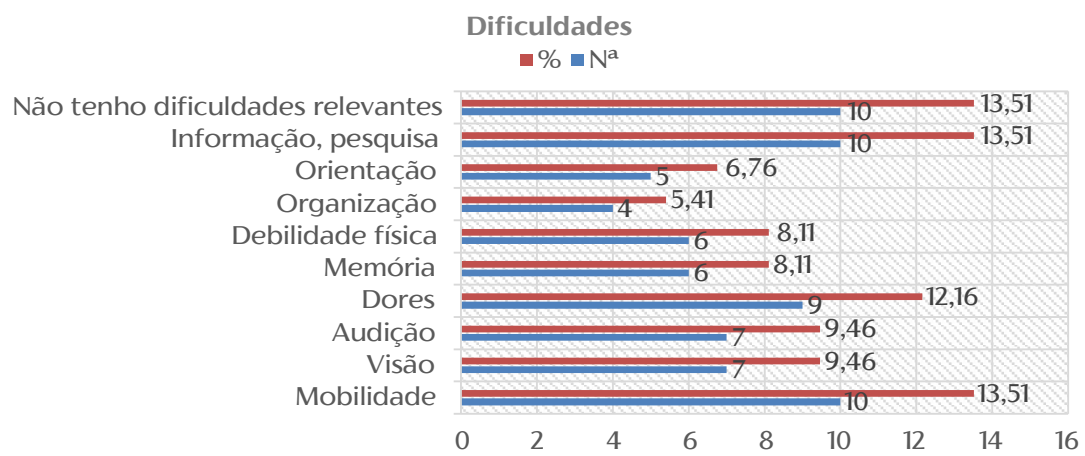

Gráfico 7. Distribuição de dificuldades relevantes citadas pelos idosos na pesquisa

Fonte: Elaborado pelos autores (2019).

A primeira pergunta do questionário era se os idosos participantes da pesquisa possuíam alguma dificuldade ou problema de saúde relevantes, na qual era possível destacar mais de uma resposta. Como podemos ver no Gráfico 7, os dados foram bem diversificados. Quando falamos em dificuldades, é importante destacar que elas não estão só relacionadas com problemas de saúde ou algum tipo de deficiência, mas qualquer tipo de dificuldade que possa ser uma barreira para o uso de aparelhos móveis como os celulares.

Contudo, podemos notar que cerca de $13,51 \%$ responderam não possuíam nenhuma dificuldade relevante, ou seja, não tinham grandes dificuldades, problemas de saúde ou deficiências. A mesma porcentagem $(13,51 \%)$ respondeu que tinha dificuldade de fazer pesquisas (ou procurar informações), mesmo índice de repostas afirmativas para as dificuldades de mobilidade (dificuldade de se locomover). Assim, os fatores de dificuldade mais apontados foram Informação, pesquisa (13,51\%), Mobilidade (13,51\%), Dores (12,16\%) e Audição e Visão (ambos com 9,46\%).

Outras respostas frequentes foram as debilidades física e de memória (cada uma com $8,11 \%$ ), presentes em seis questionários respondidos. 
As dificuldades menos apresentadas foram as de orientação e organização, com 6,76\% e 5,41\% de respostas positivas, respectivamente. Esses dados são importantes, pois, como já destacado, representam possíveis barreiras que precisam ser superadas por esses idosos no uso da tecnologia ou no seu convívio do dia a dia. Por meio delas, poderíamos compreender como a tecnologia móvel e os celulares podem ajudar esses idosos, o que um desenvolvedor de aplicativo especialmente dedicado ao público sênior precisa pensar antes de desenvolvê-lo e quais são os principais pontos de usabilidade que demandam atenção.

Sobre celulares e aplicativos

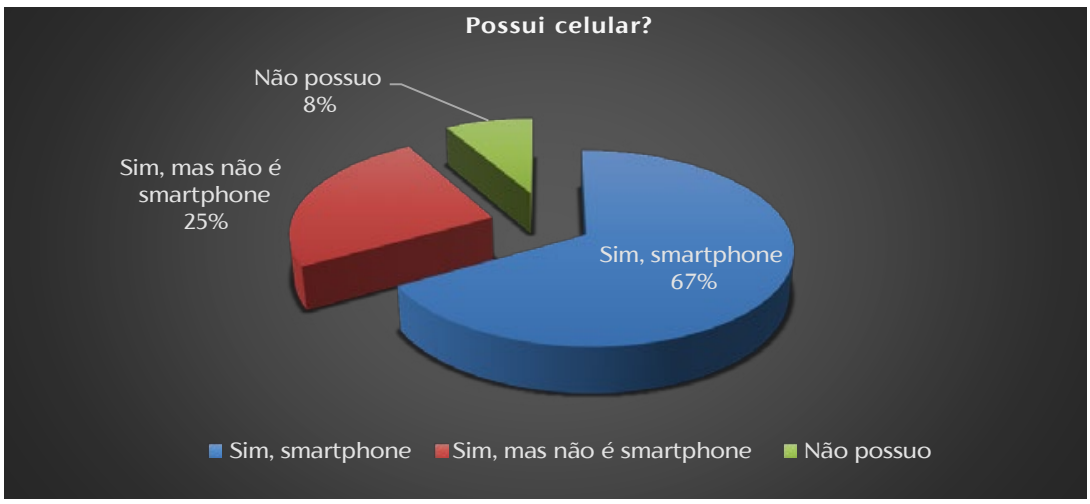

Gráfico 8. Distribuição percentual de idosos que possuem ou não aparelhos celulares

Fonte: Elaborado pelos autores (2019).

A princípio, pretendemos saber qual é a porcentagem de idosos que têm aparelhos celulares e fazem uso deles no seu dia a dia. A pergunta sobre possuir celulares foi feita no começo do questionário, para que assim fosse possível dar prosseguimento à pesquisa e alcançar seu objetivo, e possibilitava três diferentes de respostas. São elas:

- Sim, possuo aparelho celular, mas não é smartphone;

- Sim, possuo celular smartphone;

- Não possuo aparelho celular (se possível, especifique o motivo). 
Todos esses dados e informações foram coletados e tabulados no Gráfico 8, no qual podemos ver que a grande maioria dos participantes possuía aparelho celular, com total de $92 \%$, sendo que $67 \%$ tinham smartphones e outros $25 \%$ possuíam aparelhos celulares mais antigos, sem sistema Android ou IOS, mais usados para ligações, mensagens SMS, jogos e funcionalidades mais simples.

Apenas $8 \%$ dos participantes responderam que não possuíam aparelho celular. Alguns especificaram os motivos, entre os quais podemos destacar o alto custo de um aparelho celular smartphone e a falta de conhecimento sobre como mexer nos aparelhos. Embora nem todos os idosos que fazem parte desses $8 \%$ demonstrem falta de interesse em adquirir futuramente ou aprender sobre os aparelhos.

A partir dessa pergunta, prosseguimos com questionamentos em relação ao mapeamento dos aplicativos para idosos encontrados na Google Play Store e na App Store. Foi perguntado aos participantes se conheciam os apps voltados para ajudá-los e/ou ajudar pessoas com dificuldades e deficiências. Vejamos o Gráfico 9:

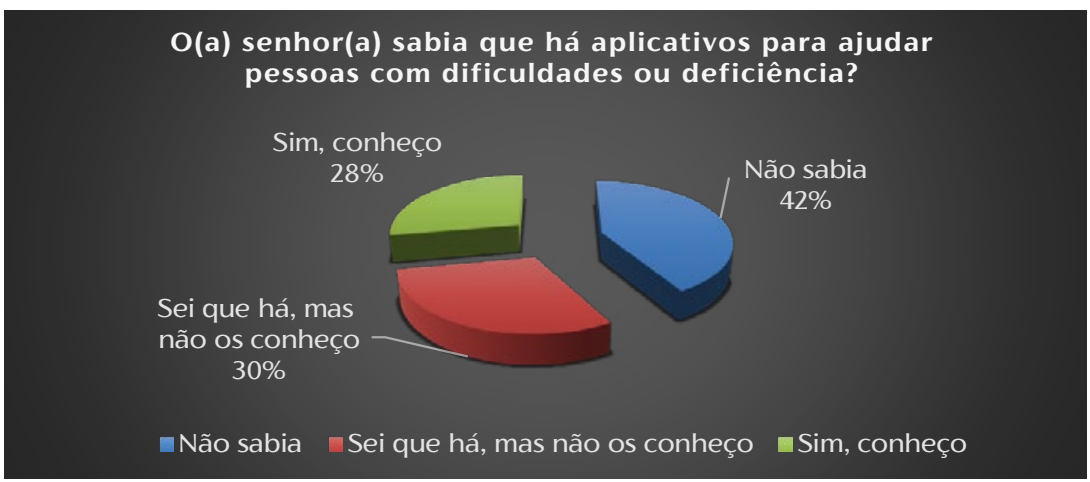

Gráfico 9. Distribuição percentual de idosos que conhecem ou não os aplicativos sociais

Fonte: Elaborado pelos autores (2019).

Com $42 \%$ das respostas (aproximadamente 15 questionários), a maioria dos idosos disse não conhecer ou nunca ter ouvido falar desses aplicativos, enquanto $30 \%$ sabiam da existência desses aplicativos, mas não os conheciam e, portanto, nunca utilizaram-nos. Por fim, 
$28 \%$ responderam que sim, conheciam alguns aplicativos, que foram divididos nas categorias expostas no Gráfico 10:

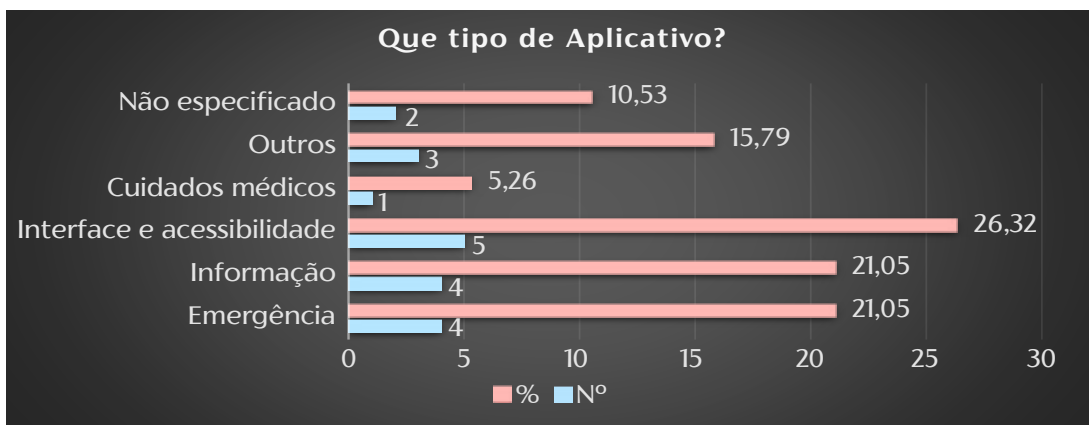

Gráfico 10. Distribuição do tipo de aplicativos sociais conhecidos pelos idosos

Fonte: Elaborado pelos autores (2019).

Observando o gráfico, podemos ver que a maioria conhecia os aplicativos de interface e acessibilidade (como a lupa para os celulares), com 26,32\% de respostas afirmativas; os de informação e emergência, com 21,05\% cada um. Somadas, as três categorias representam mais de $68 \%$ das respostas. Podemos destacar como ponto negativo que alguns idosos não especificaram o tipo de aplicativo que conheciam (10,53\%) e a pequena quantidade de idosos (5,26\%) que sabia da existência de aplicativos voltados para cuidados médicos que poderiam ajudá-los, por exemplo, com o gerenciamento de medicações.

Na opção "outros", foram destacados aplicativos de relacionamentos entre idosos, de acessibilidade para pessoas com problemas de visão e um comentário de um idoso, que se mostrou interessado em conhecer mais sobre esses aplicativos e outros que possam ajudá-lo ou ajudar pessoas próximas.

\section{Funcionalidades mais usadas dos aparelhos celulares}

Em uma das questões, foi solicitado aos idosos que selecionassem as funcionalidades do aparelho celular que mais utilizam em seu dia a 
dia, justamente buscando conhecer melhor como é o relacionamento deles com seus celulares e para que eles mais o utilizam. Foram listadas várias funcionalidades mais comuns de serem utilizadas e era possível incluir outras opções, caso a funcionalidade não se encaixasse nas alternativas fornecidas na questão. Como utilizamos várias funções dos aparelhos celulares, foi permitido selecionar mais de uma resposta. Os resultados foram compilados no Gráfico 11:

\section{FUNCIONALIDADES MAIS USADAS}

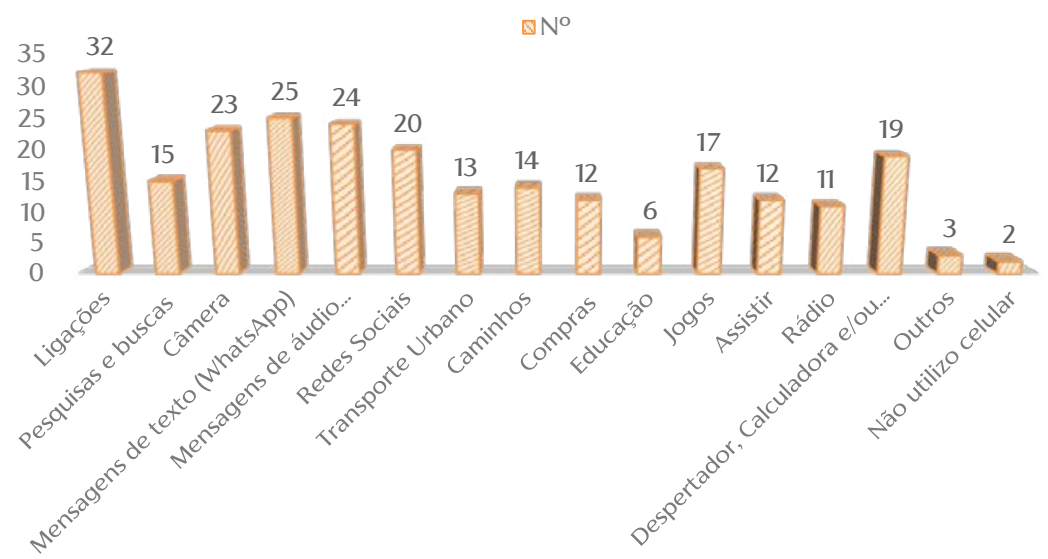

Gráfico 11. Distribuição das funcionalidades dos celulares mais usadas pelos idosos

Fonte: Elaborado pelos autores (2019).

Como podemos ver, as funcionalidades mais usadas pelos idosos foram as de ligações, o aplicativo WhatsApp (mensagens de texto e áudio), câmera, redes sociais e despertador, calculadora elou relógio. Podemos notar que essas funcionalidades são mais simples de serem utilizadas e aprendidas e estão relacionadas a meios de comunicação com amigos, parentes e familiares (exceto despertador, calculadora e/ou relógio, que são tipos de aplicações que todos usamos com frequência). Isso pode indicar que os celulares aproximam os idosos de parentes e amigos, ajudando-os a ter uma vida social mais ativa por meio da interação, além de ser um importante meio de comunicação para possíveis emergências e localização desses idosos. 
Podemos ver que os resultados foram satisfatórios em várias funções utilizadas além das destacadas acima: os jogos, pesquisas e buscas, caminhos, transporte urbano, compras, assistir filmes, séries e TV e ouvir rádio apresentaram resultados expressivos (acima de 10 respostas registradas). É interessante destacar os índices de respostas para transporte urbano e caminhos, importantes para facilitar a locomoção desses idosos para diversos lugares, além do uso do celular para compras, o que mostra que a resistência dos idosos em realizar aquisições ou transações financeiras pela internet vem caindo, embora eles ainda prefiram fazer pessoalmente.

Apenas duas respostas disseram não utilizar celular ou nenhuma funcionalidade, lembrando que não possuir o aparelho não necessariamente impede que essas pessoas utilizem alguma aplicação ou função dos celulares com algum fim ou objetivo. Apenas três citaram outras funcionalidades como leitura de notícias (jornal), mensagens SMS e aplicativo de culinária. Foram registradas apenas seis respostas da classificação educação, até porque o EaD e muitos apps para essa área ainda estão em desenvolvimento em nosso país.

\section{Funcionalidades que mais poderiam ajudar}

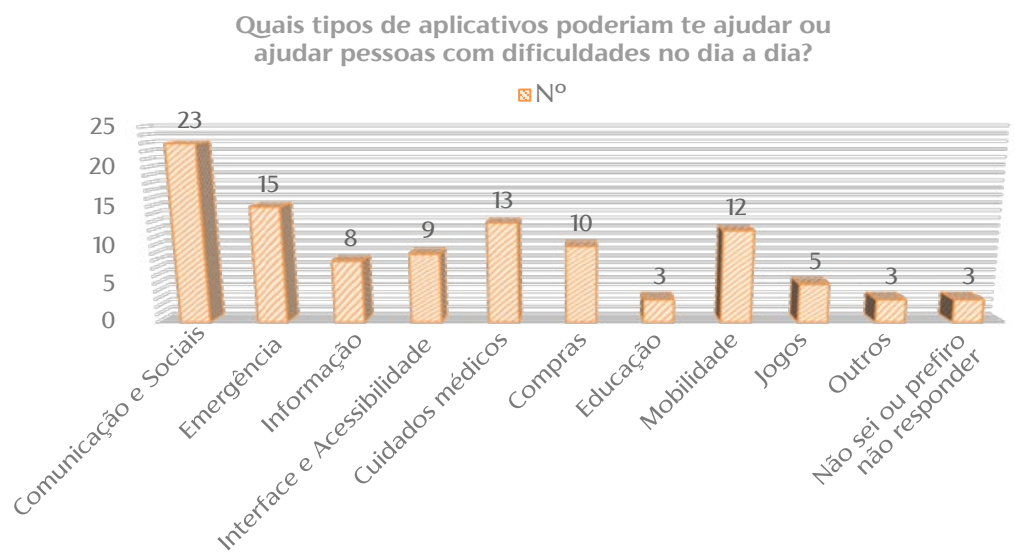

Gráfico 12. Distribuição percentual dos tipos de aplicativo que mais ajudam ou poderiam ajudar os idosos ou pessoas com dificuldades Fonte: Elaborado pelos autores (2019). 
A partir do mapeamento dos aplicativos para idosos realizado em uma das etapas desta pesquisa, os apps foram divididos em algumas categorias e outras foram somadas para buscar quais delas poderiam ajudar mais a rotina dos idosos e pessoas com deficiências ou dificuldades. Foi solicitado que respondessem quais as três categorias que acreditavam ser mais necessárias para facilitar ou ajudá-los em suas tarefas ou rotina.

Como podemos observar no Gráfico 12, as cinco categorias com mais votos foram: comunicação e sociais (23 votos), emergência (15 votos), cuidados médicos (13 votos), mobilidade (12 votos) e por fim compras (10 votos). Duas delas estão relacionadas ao ramo da saúde e cuidados médicos (emergência e cuidados médicos), que totalizou 28 votos; duas buscam facilitar a locomoção (mobilidade e compras, já que com a entrega, não é preciso se locomover até as lojas), totalizando 22 votos; e por fim, comunicação e sociais, que são os aplicativos que facilitam a interação entre idosos, familiares e amigos, além de aproximá-los de uma importante ferramenta de comunicação que pode auxiliar na solicitação de socorro e ajuda.

As categorias de aplicativos menos respondidas foram: jogos (5 votos), educação (3 votos) e não sei ou prefiro não responder (3 votos).

\section{Visão sobre a tecnologia}

Com o objetivo de compreender melhor como esses idosos veem o impacto da tecnologia em suas rotinas ou dia a dia e qual era a disposição para mudar essa relação, por meio de cursos ou palestras que se propusessem a ensinar mais sobre aparelhos móveis e as novas tecnologias, foram feitas as perguntas expostas nos Gráficos 13 e 14: 


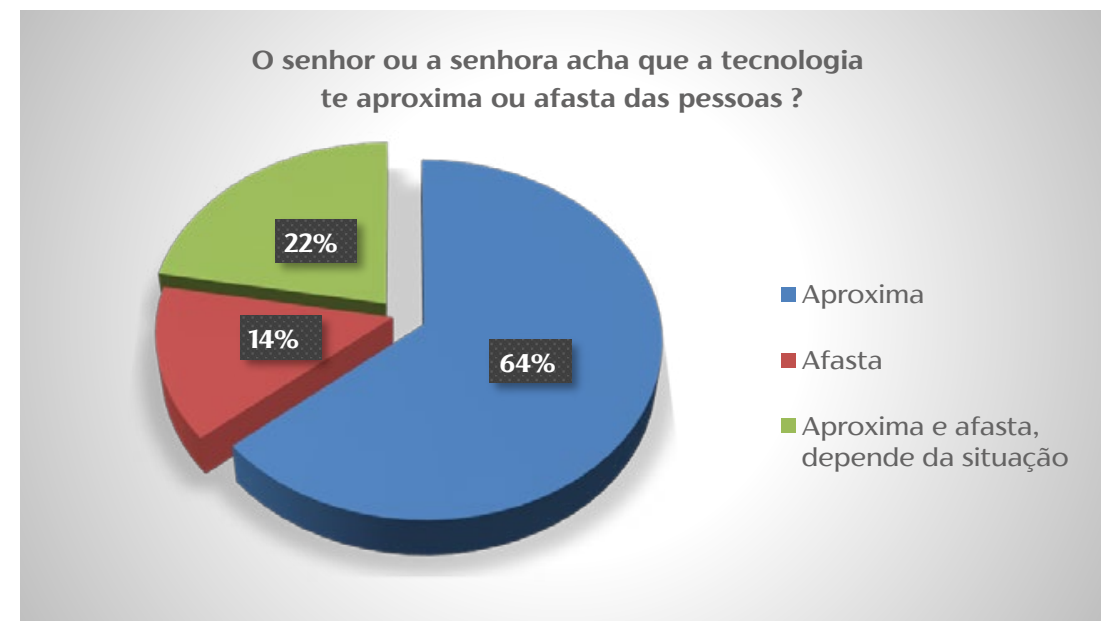

Gráfico 13. Percepção dos idosos sobre a inclusão ou exclusão ocasionada pelo uso ou não uso da tecnologia Fonte: Elaborado pelos autores (2019).

Os resultados demonstram que $64 \%$ dos idosos entendiam que a tecnologia e seus aparatos aproximavam-os mais das pessoas do que afastavam. Logo, podemos entender que a tecnologia é sim uma fonte de inclusão dos idosos na sociedade, pois nossas relações estão pautadas em relacionamentos físicos e virtuais. E inclusão digital impacta na inclusão social, mostrando a importância da aprendizagem dessas novas tecnologias pelos idosos. É importante destacar que a idade não é fator restritivo para a aprendizagem, pelo contrário, já foi mencionada a capacidade humana de aprender e se adaptar a diferentes ambientes e tecnologias, e com os idosos não é diferente, embora alguns problemas de saúde possam atrapalhar esse processo de aprendizagem.

Os $14 \%$ que responderam que viam que a tecnologia afastava-os das pessoas comentaram que, por não saber usá-las, sentem-se muitas vezes excluídos de atividades ou conversas, além disso, notaram que a tecnologia usada em excesso pode se transformar em uma barreira entre pessoas próximas. Como exemplo, uma das idosas que estava respondendo o questionário citou uma situação particular. Quando ela foi buscar o neto na aula de natação, viu que muitas das avós e mães estavam entretidas nos aparelhos enquanto as crianças nadavam e não 
se preocupavam em conversar entre elas ou em prestar atenção na aula dos netos ou filhos.

Outros 22\% responderam que dependendo da situação, veem que a tecnologia os afasta ou aproxima das pessoas. Foi destacado que, sabendo usar esses aparelhos, a tecnologia aproxima muitas pessoas que moram longe (cria pontes de comunicação) ou mesmo que moram perto, mas não têm muito tempo disponível (possuem uma rotina exaustiva entre trabalho, faculdade, escola e casa). Mas, ao mesmo tempo, pode excluir pessoas próximas novamente por causa do excesso de uso, já que não deveria eliminar a comunicação interpessoal e reduzir os relacionamentos pessoais. Por fim, foi questionado se esses idosos estariam interessados ou considerariam ingressar em cursos de tecnologia preparados especialmente para esse grupo (já existem alguns, ver exemplos no referencial teórico). O Gráfico 14 apresenta o resultado:

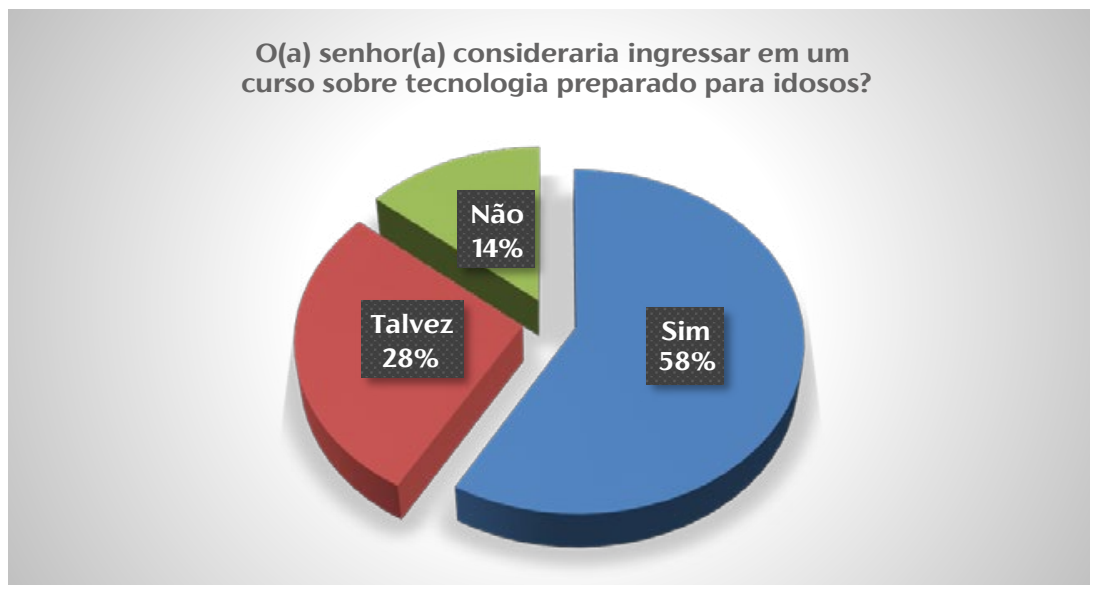

Gráfico 14. Distribuição percentual dos idosos que considerariam ou não ingressar em cursos e palestras sobre tecnologia Fonte: Elaborado pelos autores (2019).

Aproximadamente $58 \%$ dos idosos responderam que sim, estariam interessados ou considerariam ingressar em um curso de tecnologia. Foi perguntado o que eles gostariam e achavam mais importante aprender, e várias respostas registraram interesse em estudar como manusear melhor esses aparelhos móveis (celulares, notebooks 
e tablets) e seus aplicativos, as funções, como instalar e desinstalar aplicativos, como usar etc.

Os 14\% que responderam que não considerariam ingressar em um curso de tecnologia especializado para idosos destacaram como principais causas a falta de interesse em aprender sobre esse tema e que já consideravam possuir conhecimentos suficientes para lidar bem com os aparatos tecnológicos. Por fim, $28 \%$ declararam que talvez consideraria ingressar em cursos ou aulas sobre tecnologia, que dependeria de muitos fatores, entre eles o conteúdo que seria ensinado.

WhatsApp e aplicativos de redes sociais são os preferidos dos idosos

Quando questionado para os idosos na pesquisa quais eram os aplicativos mais fáceis de usar e porque, foi interessante notar que praticamente todas as respostas registraram o aplicativo de comunicação WhatsApp e outros de vínculos sociais, como Facebook e Instagram, como os mais fáceis e com maior frequência de uso no dia a dia para a comunicação com familiares e amigos.

A fácil usabilidade do WhatsApp, aplicativo de envio de mensagens, fotos, vídeos etc. de forma instantânea, ajuda na sua grande utilização pelos idosos, pois até mesmo sem saber ler, eles conseguem enviar e escutar áudios, podendo se comunicar sem maiores dificuldades. A importância da usabilidade desse e dos demais aplicativos de comunicação e sociais é muito grande, pois ajuda os idosos a se manterem sociáveis com seus colegas ou familiares, além de ser uma ferramenta de comunicação para momentos de urgência ou de necessidade de ajuda.

Outra funcionalidade bastante destacada foi a de ligação, demonstrando que embora aplicativos de mensagens instantânea tenham se popularizado, muitos idosos preferem utilizar o recurso básico do celular para se comunicar.

Também destacaram-se aplicativos como Uber, Waze e Google Maps (transporte urbano e localização), e-mail e Google para realizar buscas e pesquisas na internet. Foi questionado quais eram as maiores 
dificuldades desses idosos ao mexer em smartphones, e as respostas mais frequentes foram de instalar e usar os aplicativos, que alguns apps são difíceis de mexer e entender (usabilidade), de configurar o aparelho e de não saber o que fazer quando os celulares travam. Por fim, duas das respostas destacavam que foi difícil criar o hábito de mexer nesses aparelhos, como destacado no referencial, os costumes ou os fatores socioculturais podem se tornar uma grande barreira para os idosos no uso da tecnologia. Segundo um dos idosos, "o difícil é aprender, depois que aprende como funciona vira um hábito mexer".

\section{Entrevista em profundidade com três idosos}

Realizamos entrevistas mais profundas com três idosos que já haviam respondido o questionário para poder entender um pouco mais da visão deles a respeito de aplicativos que visam melhorar a qualidade de vida de idosos e do quanto esses são efetivos. O retorno que obtivemos de forma geral por parte dos três entrevistados é que o conhecimento sobre a existência de aplicativos focados ao público idoso é muito raro, o que faz com que a grande maioria das pessoas não tenha nem a iniciativa de procurá-los.

Entretanto, um dos idosos entrevistados afirmou que sua cuidadora já tinha conhecimento da existência de alguns aplicativos, porém defendia que eles não eram realmente efetivos, apresentando somente funções que poderiam ser realizadas pelos próprios smartphones, sem o uso de apps. Por exemplo, no lugar de alarmes para remédios, ela afirma que pode usar a própria função de alarme do celular; sobre aplicativos de emergência, ela afirmou que é mais complicado para o idoso acessar o aplicativo para obter essa função do que simplesmente deixar salvo nos contatos um número para alguma emergência.

Sendo assim, podemos apontar que existe um ponto de vista que afirma a inutilidade de alguns dos aplicativos que foram criados com o intuito de ajudar na vida cotidiana desse público.

Outra informação relevante que obtivemos foi a de que a dificuldade de adaptação às tecnologias dos smartphones para os idosos é, 
muitas vezes, extremamente desafiadora, o que prejudica muito o acesso desse público aos aplicativos que poderiam ser muito facilitadores no seu dia a dia.

\section{Pesquisa com familiares e cuidadores}

A seguir, vemos os resultados mais importantes da segunda pesquisa de campo, realizada com familiares elou cuidadores de idosos que trabalham na área da saúde, em hospitais, laboratórios, clínicas ou casas de repouso, buscando compreender como esse grupo vê a relação entre a tecnologia e os idosos. Foram aplicados 20 questionários e aqui não serão apresentadas as informações socioeconômicas dos participantes porque notamos que isso não alteraria a interpretação dos dados. Os principais resultados foram:

- Quando perguntado se utilizavam aplicativos para se comunicar com os idosos e quais eram utilizados, cerca de $65 \%$ disseram que usavam algum tipo de aplicativo para se comunicar com o público sênior, sendo $86,67 \%$ via WhatsApp e $13,33 \%$ via Messenger, do Facebook. Outros 35\% responderam não utilizar nenhum tipo de aplicativo para se comunicar com os idosos;

- Quando perguntado se viam que a tecnologia ajudava ou atrapalhava no envelhecimento saudável dos idosos, $90 \%$ responderam que ajudava e apenas $10 \%$ que atrapalhava;

- Além disso, foi questionado se acreditavam que a tecnologia móvel poderia ajudar os idosos em suas atividades e ações: $65 \%$ responderam que sim, $30 \%$ parcialmente e $5 \%$ preferiram não responder.

Todos os dados apresentados até aqui são parte dos resultados da pesquisa de campo que demonstram e confirmam importantes afirmações, como a importância dos familiares e cuidadores para incentivar e ensinar os idosos a aprenderem a manusear os celulares. Mas, como ponto negativo, destaca-se o desconhecimento desses sobre os apps especialmente desenvolvidos para idosos. O Gráfico 15 apresenta alguns outros resultados. 


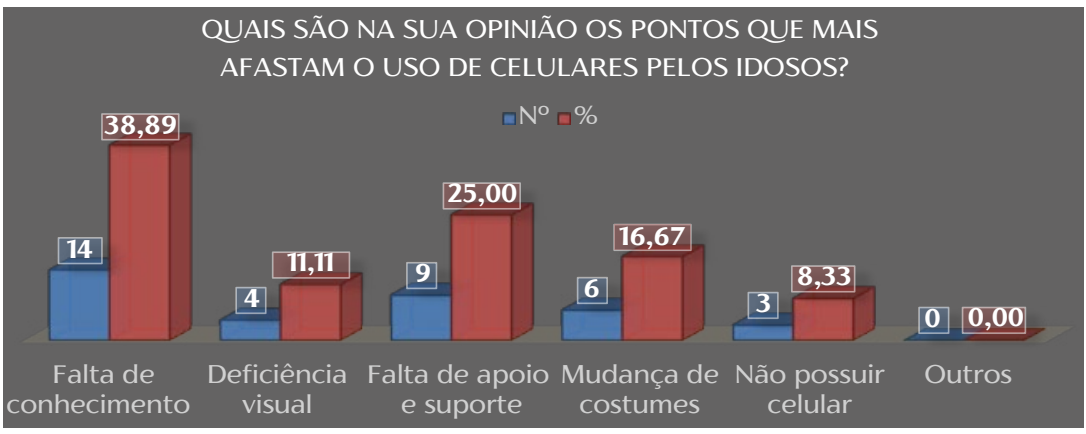

Gráfico 15. Distribuição percentual dos pontos que mais afastam os idosos do uso dos celulares segundo seus parentes ou cuidadores Fonte: Elaborado pelos autores (2019).

Foi solicitado na pesquisa que os entrevistados escolhessem duas dificuldades que, em seu ponto de vista, mais separavam os idosos do uso dos celulares. Como evidencia o Gráfico 15, as respostas com maiores porcentagens foram a falta de conhecimento (38,89\%) e falta de apoio e suporte (25\%), que juntas somaram cerca de 64\% das devolutivas. Isso demonstra que esse grupo tem um papel fundamental para que os idosos sintam-se incentivados a aprender e a manusear os aparelhos celulares e outros tipos de dispositivos móveis. Outras dificuldades com resultados expressivos foram mudanças de costumes (16,67\%) e deficiência visual (11,11\%).

Por fim, não foram citadas outras dificuldades e a menos mencionada foi a de não possuir aparelho celular, demonstrando que o acesso a esses dispositivos foi muito facilitado com o passar do tempo.

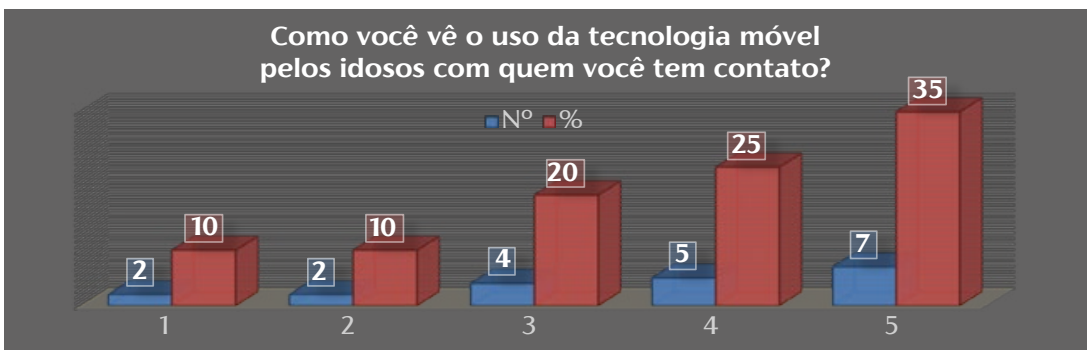

Gráfico 16. Distribuição percentual da relação do uso da tecnologia móvel pelos idosos segundo a visão dos parentes ou cuidadores Fonte: Elaborado pelos autores (2019). 
Na questão exposta no Gráfico 16, foi requerido aos familiares dos idosos ou cuidadores que dessem uma nota de 1 a 5 para como eles viam o uso da tecnologia móvel pelos idosos com quem tinham ou têm contato. Como podemos ver, apenas $20 \%$ responderam que é pouco usada (notas 1 e 2), $20 \%$ como medianamente usada (nota 3) e $60 \%$ como muito usada (notas 4 e 5). Isso confirma os dados demonstrados acima e explicados, de que os idosos de hoje utilizam cada vez mais os aparatos tecnológicos e esse número só tende a aumentar, já que a nossa sociedade e ambiente estão cada vez mais tecnológicos e os idosos não querem e não devem ficar para trás.

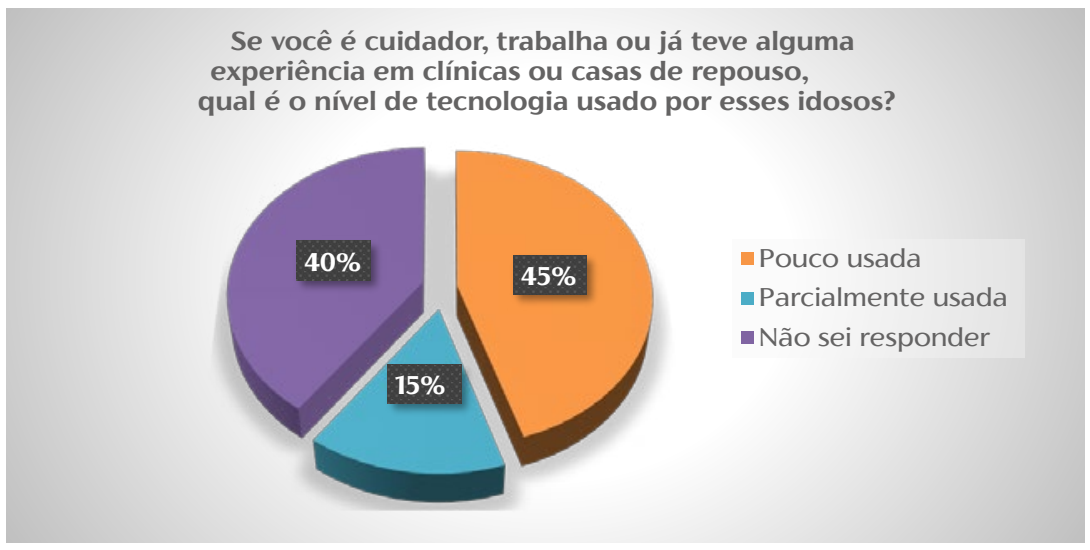

Gráfico 17. Distribuição percentual do nível de tecnologia usado pelos idosos em casas de repousos ou clínicas

Fonte: Elaborado pelos autores (2019).

Podemos ver no Gráfico 17 que 40\% dos participantes da pesquisa disseram não saber responder, pois nunca tiveram algum tipo de experiência em casas de repousos ou clínicas, seja como profissional ou visitando parentes e amigos idosos. Dos $60 \%$ restantes, $45 \%$ responderam que o nível de tecnologia utilizado nesses ambientes é pequeno ou que esta é pouca utilizada, enquanto $15 \%$ afirmaram que é parcialmente usada. Podemos notar que esses ambientes são de difícil utilização da tecnologia pelos idosos por conta de alguns fatores, como problemas de saúde e condições físicas. Nenhum dos que responderam citou já ter trabalhado em casas de repouso ou clínicas com um alto uso de 
tecnologia pelos idosos. Ainda sobre esse assunto, foi questionado se acreditam que a utilização de celulares, notebook e outros aparatos tecnológicos móveis pelos idosos em clínicas ou casas de repouso seria possível. Do total das respostas, 50\% disseram que parcialmente, $45 \%$ que sim e apenas 5\% que não. Esses dados demonstram que, dependendo da situação, a tecnologia móvel poderia ser uma boa aliada dos funcionários, idosos e familiares.

\section{Conclusão}

As tecnologias revolucionaram os hábitos, costumes e a maneira de viver de diferentes pessoas em diversas épocas; conforme o tempo passava, o ser humano criava soluções inovadoras para resolver problemas que geravam impactos imediatos ou futuros na sociedade e no ambiente de maneira geral. As tecnologias da informação e comunicação talvez tenham sido as que causaram maiores mudanças em nossa sociedade e nas pessoas nos últimos tempos.

Hoje, quem não sabe utilizar algumas dessas tecnologias pode ser sentenciado à exclusão digital e, consequente, à exclusão sobre determinados assuntos que estão rodando no mundo virtual, afetando assim suas relações pessoais ou seus laços familiares e impactando em um sentimento maior de exclusão social. Para os idosos, a aprendizagem dessas tecnologias se deu em um processo acelerado, já que quando elas se popularizaram, grande parte deles não sabia muito bem como manuseá-las.

De toda forma, atualmente, esse grupo etário vive um grande crescimento no número de internautas ou de usuários, ficando cada vez mais conectado à tecnologia; como exemplo, podemos ver o resultado da pesquisa, em que $92 \%$ dos idosos possuíam algum tipo de aparelho celular, seja smartphone (67\%) ou não (25\%), e apenas $8 \%$ diziam não possuir aparelho, mas sem demonstrar falta de interesse em adquirir e aprender a manuseá-los. Esse crescimento foi incentivado principalmente pelos apps de redes sociais, como Facebook e WhatsApp, além de outros que podem oferecer muitas facilidades para os idosos, como os de transporte (99App e Uber), de localização (Google Maps e Waze), de compras em farmácia, supermercados e bancos, entre outros. 
Esses aplicativos, embora não tenham sido desenvolvidos especificamente para o público sênior, demonstram um grande potencial em ajudar esses idosos a realizar parte de algumas tarefas ou ações do dia a dia com maior facilidade. Quando falamos de aplicativos de cunho social desenvolvidos propriamente para pessoas idosas, notamos um grande desconhecimento tanto da parte do público sênior (42\% não sabiam da existência, $30 \%$ sabiam que existiam, mas nunca os utilizaram e apenas $28 \%$ conheciam e utilizavam) quanto dos familiares sobre a existência e possíveis contribuições dessas ferramentas. Fica evidente também a necessidade de maior empenho dos desenvolvedores em criar apps de fácil manuseio e que realmente gerem maiores impactos na prática para esse grupo.

Outro ponto interessante de destacar é que os idosos usam os aparelhos para realizar funções diferentes, porém, de forma geral, a maioria utiliza para tarefas mais simples, como fazer ligações, ouvir música ou rádio, mandar mensagens pelo WhatsApp, tirar fotos etc. $\mathrm{O}$ alto desconhecimento e a baixa utilização dos apps sociais podem ter relação direta com a baixa qualidade e usabilidade de alguns deles, além da pouca divulgação e difícil utilização, pois é notável que esse grupo ainda passa por um processo de desenvolvimento e aprendizagem no manuseio dos aparelhos móveis, tanto que nesta pesquisa foram apresentados muitos motivos e dificuldades de uso. Porém, aprender faz parte da vida humana independentemente da idade e de outros fatores, embora alguns problemas de saúde que esse público apresenta possam prejudicar esse processo.

Em relação à utilização da tecnologia, vemos que o empenho dos familiares em ajudar os idosos a mexer nestes é grande, embora, este tenha o principal objetivo de facilitar o processo de interação nas redes sociais e de comunicação, já que estes também desconheciam os apps sociais (95\% diziam não conhecer tais apps).

Por fim, vemos que a tecnologia móvel é pouco utilizada em casas de repouso e clínicas, muito pelas condições de alguns idosos e pela difícil penetração nesses ambientes. Podemos notar que alguns apps seriam de grande valia para o uso de cuidadores e familiares, por exemplo, o caixa de remédios para gerenciamento de medicamentos. Mas, para os idosos, a utilização dependeria do nível de 
domínio do celular, já que sua usabilidade não é simples e apresenta várias telas durante o uso.

A pesquisa indica também fatores significantes para a forma como é possibilitado ao idoso no Brasil se informar e acessar a tecnologia digital móvel (smartphones) e suas ferramentas. Além da idade, existe outro fator importante a ser mencionado que é a renda média do idoso em questão. Apesar de a tecnologia atualmente ser bastante popularizada, o acesso às informações completas ainda é mais dificultoso para idosos com uma menor renda, de forma que esse grupo ou utiliza as funções mais básicas dos smartphones ou nem mesmo faz uso dessa tecnologia.

Dessa forma, voltamos ao problema de pesquisa: os apps desenvolvidos para os idosos criam possibilidades para todos os seus usuários de forma a melhorar sua inclusão social? Podemos concluir que diminuir a exclusão digital é aumentar as chances de inclusão social e da participação dos idosos na sociedade e em suas relações sociais, mesmo que somente isso não seja suficiente para garantir um envelhecimento saudável e ativo. Os apps que não foram criados especificamente para os idosos contribuem de maneira significativa, ajudando-os na realização de tarefas e ações, já que são mais utilizados. Notamos que existem alguns bons apps sociais desenvolvidos para esse público, porém, são poucos conhecidos e utilizados. Logo, a tecnologia e seus aparatos são importantes ferramentas para ajudá-los, mas ainda é necessário o desenvolvimento de aplicações que sejam capazes de unir alguns fatores primordiais para sua utilização pelo público sênior, entre eles uma boa usabilidade, gratuidade e principalmente utilidade.

\section{Referências bibliográficas}

ALVARENGA, Darlan; BRITO, Carlos. 1 em cada 4 brasileiros terá mais de 65 anos em 2060, aponta IBGE. G1, São Paulo e Rio de Janeiro, 25 jul. 2018. Economia. Disponível em: https://glo.bo/2YVCysX. Acesso em: 10 jan. 2019.

BRASIL. Lei Federal $\mathbf{n}^{\circ}$ 10.741, de 1 de outubro 2003. Dispõe sobre o Estatuto do Idoso e dá outras providências. Brasília, DF [2003]. Disponível em: https://bit.ly/3IF0gDG. Acesso em: 23 set. 2018. 
COMITÊ GESTOR DA INTERNET NO BRASIL. TIC Domicílios: Pesquisa sobre o uso das Tecnologias de Informação e comunicação nos Domicílios Brasileiros 2016. São Paulo: Núcleo de Informação e Coordenação do Ponto BR; Comitê Gestor da Internet no Brasil, 2017. Disponível em: https://bit.ly/2EY9udu. Acesso em: 8 fev. 2019.

COMITÊ GESTOR DA INTERNET NO BRASIL. TIC Domicílios: Pesquisa sobre o uso das Tecnologias de Informação e comunicação nos Domicílios Brasileiros 2018. São Paulo: Núcleo de Informação e Coordenação do Ponto BR; Comitê Gestor da Internet no Brasil, 2018. Disponível em: https://bit.ly/3hPAWIH. Acesso em: 30 jul. 2020.

FONSECA, António Manuel. Desenvolvimento psicológico e processos de transição adaptação no discurso do envelhecimento. In: PAÚL, Constança; RIBEIRO, Oscar. Manual de Gerontologia. Lisboa: Lidel, 2012. p. 96-104.

LEMOS, André (org.). Cidade digital: portais, inclusão e redes no Brasil. Salvador: Edufba, 2007.

NAÇÕES UNIDAS (Brasil). A ONU e as pessoas idosas. Nações Unidas Brasil, Rio de Janeiro, 23 set. 2014. Disponível em: https://bit.ly/2EPqsuy. Acesso em 5 jun. 2019.

PENA, Rodolfo F. Alves. Pirâmide etária da população Brasileira. Mundo Educação, Goiânia, 7 maio 2015. Disponível em: https://bit.ly/34VIO9k. Acesso em: 10 jan. 2019.

SALES, Márcia Barros de et al. Tecnologias de informação e comunicação via Web: Preferências de uso de um grupo de usuários idosos. Revista Kairós Gerontologia, [S.I.], v. 17, n. 3, p. 59-77, 2014. Disponível em: https://bit.ly/3jAjske. Acesso em: 01 jun. 2019.

SIGNIFICADOS. Significados, 2014. Encontre aqui Significados, Conceitos e Definições sobre os mais variados assuntos. Disponível em: https:// www.significados.com.br/. Acesso em: 10 jan. 2019.

SILVEIRA, Sérgio Amadeu da. Exclusão digital: a miséria na era da informação. São Paulo: Fundação Perseu Abramo, 2001.

SILVEIRA, Daniel. Brasil ganha 10 milhões de internautas em 1 ano, aponta IBGE. G1, Rio de Janeiro, 20 dez. 2018. Economia. Disponível em: https://glo.bo/2EQv5Eu. Acesso em: 1 jun. 2019 
SOUSA, Liliana; FIGUEIREDO, Daniela; CERQUEIRA, Margarida. Envelhecer em família: Os cuidados familiares na velhice. 2. ed. Porto: Ambar, 2006.

TEIXEIRA, Paulo. Envelhecendo passo a passo. Portal dos Psicólogos, Porto, 2006. Disponível em: https://bit.ly/2Gch5FG . Acesso em: 19 nov. 2018. UNITED NATIONS. Political Declaration and Madrid Plan of Action and its Implementation. In: World Assembly on Ageing, 2., 2002, Madrid. Proceedings [...]. New York: United Nations, 2002. Disponível em: https://bit.ly/31O8jGk. Acesso em: 5 jun. 2019.

VÁZQUEZ, Maria Yolanda García et al. Mobile Phones and Psychosocial Therapies with Vulnerable People: a First State of the Art. J Med Syst, New York, v. 40, 2016. Disponível em: https://bit.ly/2Dieqcs. Acesso em: 17 dez. 2018.

ZIMERMAN, Guite. Velhice: aspectos biopsicossociais. Porto Alegre: Artmed, 2000. 



\title{
Responsabilidade social em uma empresa de cosmético
}

\author{
Mariana Soares de Araujo \\ José lesca Rodrigues
}

\begin{abstract}
Resumo
A responsabilidade social está relacionada ao papel da empresa como detentora de recursos necessários para promover um desenvolvimento sustentável, além dos requisitos obrigatórios por lei. Uma empresa deve seguir uma conduta ética e transparente, implementando ações que beneficiam a sociedade como um todo, tendo boa relação com os seus stakeholders, buscando atender as necessidades atuais da população sem comprometer a capacidade de futuras gerações se desenvolverem harmoniosamente.

Para entender como se coloca a responsabilidade social em prática, este estudo utiliza como modelo uma empresa de cosmético. Quanto aos fins, trata-se de uma pesquisa descritiva, pois expõe as características socioculturais de uma empresa. Quantos aos meios: um estudo de caso; uma pesquisa bibliográfica, pois utiliza material acessível ao público em geral. Pela acessibilidade e por sua transparência, o exemplo utilizado é o da Natura S.A., empresa brasileira com atuação na área de cosméticos e saúde reconhecida pelo seu compromisso com a sustentabilidade e apontada por diversas vezes como destaque, por sua atuação social, pelo Instituto Ethos de Empresas e Responsabilidade Social.
\end{abstract}

Palavras-chave: Responsabilidade social. Sustentabilidade. Stakeholders. Natura. Cosméticos. 


\section{Introdução}

A responsabilidade social empresarial leva em consideração que as empresas têm responsabilidade direta face a problemas que afetam a sociedade como um todo.

Durante muito tempo a função social empresarial se resumia a gerar empregos, maximizar o seu lucro e pagar impostos que serviriam para o Estado promover ações sociais. Porém, como consequência da industrialização, surgiram diversos problemas relacionados à baixa qualidade de vida e precarização das relações trabalhistas. Esse ambiente fez com que a sociedade passasse a pressionar o governo e as empresas por melhores condições de vida e no trabalho que pudessem atenuar problemas sociais.

A sociedade contemporânea está mais preocupada e consciente em relação aos direitos humanos e ao impacto que suas escolhas de consumo podem gerar. Questões como a relação entre fornecedores e colaboradores, composição do produto e causas em que a organização atua estão se tornando fundamentais. Tudo isso gera uma expectativa quanto à postura tomada pelo setor privado, sendo cobrado um papel mais ativo e transparente das empresas.

As organizações, por sua vez, como parte atuante, detentoras do poder econômico e propulsoras de inovações e tecnologias, buscam engajamento em iniciativas que visam um propósito maior; abrangendo necessidades culturais e sociais capazes de gerar benefícios tanto para a empresa como para toda a sociedade. Para tanto, é necessário adotar uma postura de transparência e ética coerente ao seu papel como agente de mudança na sociedade.

Um aspecto a ser considerado é a inserção de novas tecnologias, o que modificou a velocidade e o acesso às informações. As pessoas estão cada vez mais informadas sobre as práticas adotadas pela empresa, e posturas antiéticas tornam-se virais. As empresas deixam de ter o controle absoluto das informações perante a essa interdependência da sociedade - portanto, o melhor caminho é o da transparência focada nos seus valores.

O ideal é que seja adotada uma visão sistêmica, ou seja: identificar os processos como um todo, considerando seus impactos internamente 
e externamente. Desse modo, aumenta-se a percepção de como a empresa pode interferir nos interesses e necessidades da sociedade, alavancando competências do negócio e gerando valor.

A responsabilidade social corporativa está ligada ao desenvolvimento econômico, proporcionando melhorias na qualidade de vida não só de seus empregados e de seus familiares, mas como também de toda a comunidade local e da sociedade. A cadeia produtiva deve ser analisada por completo de modo a reduzir ao máximo o impacto ambiental e social.

O engajamento das empresas em exercer uma postura cidadã é retrato de uma pressão da sociedade que exige que as organizações foquem além do resultado financeiro. Essa postura gera um desafio: o de balancear o lucro e competitividade com o propósito da sustentabilidade.

Como maneira de autoavaliação de práticas de responsabilidade social e apoio na sua definição de estratégia, a empresa tem à sua disponibilidade indicadores que permitem avaliar a transparência corporativa, os valores da organização, o público interno, meio ambiente, os fornecedores, consumidores e clientes, a comunidade, o governo e sociedade. Com base nos indicadores, é fundamental que as empresas adotem metas claras, afirmando um compromisso e orientando suas ações a curto e longo prazo.

No Brasil, o Governo criou leis de incentivo à cultura, ao esporte e ao social, renunciando parte dos impostos que recebe de pessoas ou empresas para que esses possam ser destinados a diversos projetos.

\section{Referencial teórico}

Nas teorias administrativas tradicionais, a responsabilidade das empresas resumia-se a seguir as leis e maximizar o lucro - o interesse máximo a ser considerado era o dos proprietários.

Segundo Penido (2017, p. 14), finda a Segunda Guerra Mundial, a sociedade acordou para o impacto das ações humanas sobre o meio ambiente. Perceberam a necessidade de se pensar em um novo tipo de desenvolvimento em vista das transformações pelas quais passava a sociedade contemporânea. 
Na década de 1970 percebeu-se a importância da compatibilização do desenvolvimento social e industrial na busca da diminuição de desigualdades globais. Foi nessa época que surgiu o conceito de desenvolvimento sustentável, que dizia que o crescimento econômico não deveria implicar em degradação ambiental.

A abordagem da atuação social empresarial surgiu no século $X X$ com o filantropismo. Em seguida, com o esgotamento do modelo industrial e o desenvolvimento da sociedade pós-industrial, o conceito evoluiu, passando a incorporar os anseios dos agentes sociais no plano de negócios das corporações (TENÓRIO, 2004. p. 13).

A responsabilidade social passa a ser vista como uma questão ética e transforma a concepção do papel da empresa na sociedade - sua obrigação deixa de se basear apenas em obrigações legais e em questões econômicas. O seu foco está em questões sociais e culturais, envolvendo todo o seu grupo de stakeholders.

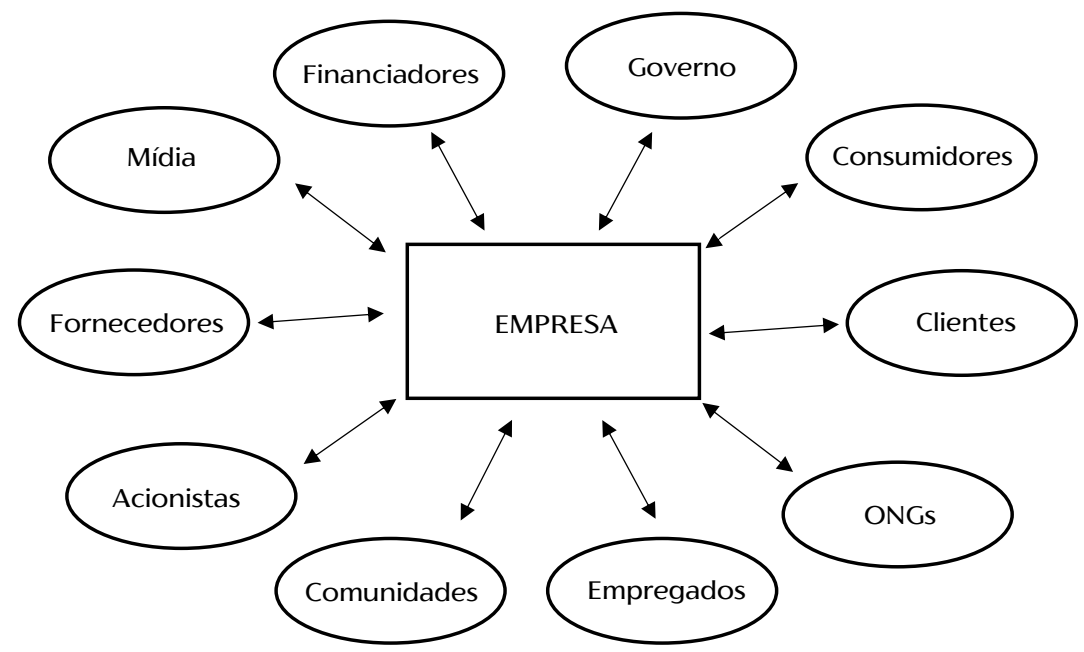

Figura 1. Visão de stakeholders de uma empresa Fonte: Empresas na sociedade (OLIVEIRA, 2013, p. 32)

É identificada a necessidade de um realinhamento das prioridades sociais, com a responsabilidade social corporativa sendo considerada um elemento importante nos processos decisórios das empresas. 
A responsabilidade social pressupõe uma nova filosofia, uma nova orientação para as organizações produtivas. É uma prática até certo ponto revolucionária, pois coloca em questão a relação entre capital e trabalho, preconizando uma alteração em sua essência propõe que os seres humanos ocupem lugar de destaque nessa relação. (PASSOS, 2012, p. 166).

A ambição desenfreada pela realização de objetivos econômicos já não se sustenta, o que é resultado de um conjunto de ações da empresa e da conexão com os valores e filosofia que devem estar presentes na tomada de decisão. Além do âmbito econômico-financeiro, as esferas social, ambiental e humana também devem estar integradas. A organização deve cumprir com seu papel de transformadora social, almejando resultados que colaborem para um mundo melhor.

Em 1968 aconteceu a criação do Clube de Roma, uma organização informal com reuniões para debates acerca de componentes que formam o sistema global de maneira interdependente, sendo eles econômicos, políticos, naturais e sociais.

A Conferência de Estocolmo, ocorrida em 1972, foi o primeiro evento da Organização das Nações Unidas (ONU) a apresentar a preocupação com o meio ambiente. Nesse evento foi criado um Manifesto Ambiental com 19 princípios norteadores para uma nova agenda ambiental das Nações Unidas; um dos princípios é o de que os recursos naturais precisam de uma gestão adequada para que não se esgotem e continuem presentes e disponíveis para as próximas gerações. Foram 113 países participantes, dentre eles os Brasil.

Através do Relatório de Brundtland, a ONU estabeleceu em 1987 que o desenvolvimento sustentável deveria ser o princípio central orientador para governos, instituições de ensino e empresas.

A Constituição de 1988, conhecida como Constituição Cidadã, trouxe para os brasileiros importantes contribuições para a garantia de direitos sociais e consolidou direitos trabalhistas, incorporados até a atualidade. Também trouxe, porém, a obrigação da equidade intergeracional, ou seja, a obrigação de preservar o meio ambiente para as futuras gerações.

A responsabilidade sociocultural e ambiental influi no desempenho financeiro das empresas da atualidade e acabam por se tornar um 
diferencial competitivo. A Global Reporting Initiative (GRI) é uma organização que permite, pelo meio de diretrizes, a elaboração de relatórios que refletem os impactos positivos e negativos do negócio de forma padronizada. Suas diretrizes envolvem questões do meio ambiente, sociais e econômicas.

Empresas que adotam a GRI demonstram seu comprometimento com práticas sustentáveis e éticas, e a preocupação com a transparência em seus processos e relações.

O Índice de Sustentabilidade Empresarial (ISE) é uma ferramenta aplicada nas empresas listadas na B3 (Bolsa de Valores) que permite uma análise comparativa da performance em sustentabilidade corporativa para incentivar a responsabilidade ética nas organizações. Baseia-se na eficiência econômica, no equilíbrio ambiental, na governança corporativa e na justiça social.

O cálculo do ISE é feito com base em questionários respondidos pelas organizações que possuem interesse em participar. São três categorias: simulado, elegível e treineira. A categoria "simulado" é aberta a todas as empresas listadas na BM\&FBOVESPA; já as outras categorias são exclusivas para empresas que estejam entre as duzentas ações mais líquidas.

O Pacto Global, iniciativa lançada em 2000, apresenta dez princípios universais nas áreas de direitos humanos, trabalho, meio ambiente e anticorrupção que, alinhadas às estratégias e operações organizacionais, contribuem para o desenvolvimento de ações que enfrentem os desafios da sociedade. Esse é o principal canal da ONU com o setor privado.

As organizações que fazer parte do Pacto se comprometem a cumprir com esses princípios.

A responsabilidade social é direcionada em duas esferas diferentes: a chamada responsabilidade social interna é voltada para a atenção aos funcionários e trabalhadores da própria empresa, e a segunda é voltada para comunidade onde a empresa atua, estabelecida como responsabilidade social externa.

Através de acordos voluntários, as organizações privadas se comprometem na realização de ações de melhoria ao desempenho ambiental. Os instrumentos de política ambiental podem ser de quatro tipos, como mostra a Figura 2. 


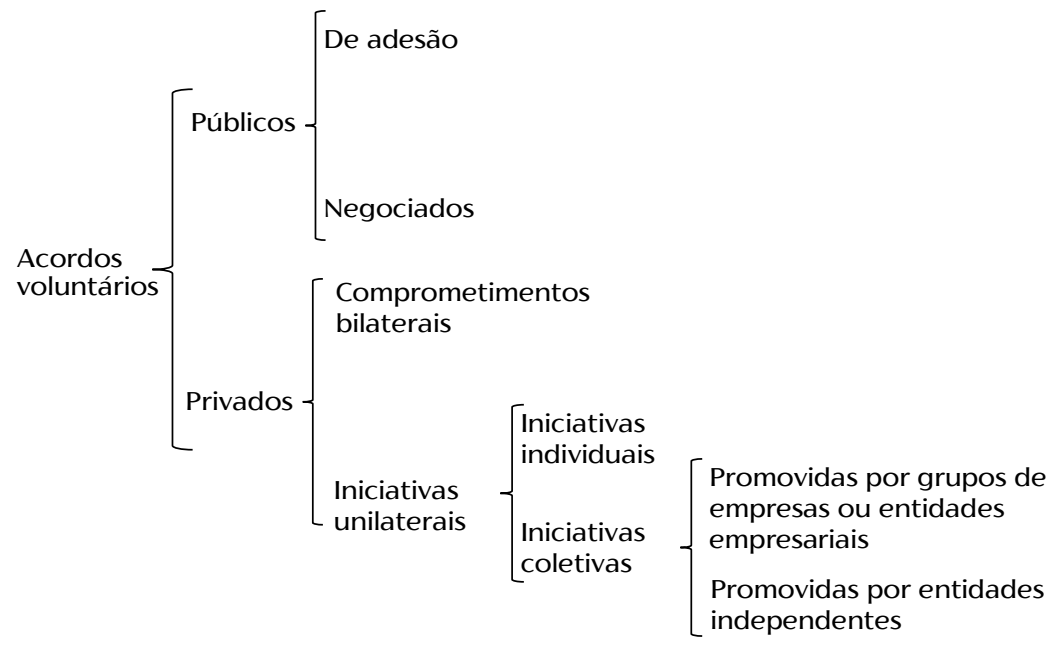

Figura 2. Instrumentos de política ambiental

Fonte: Adaptada e ampliada de OCDE (BARBIERI, 2016, p.68).

De acordo com Barbieri (2016, p. 68), os programas públicos de adesão voluntária e os acordos negociados podem ser considerados instrumentos de política pública. Os acordos voluntários, públicos ou privados, resultam do aperfeiçoamento das relações entre órgãos públicos e agentes privados em relação às questões ambientais, por isso são considerados formas de autorregulamentação.

Os contratos de acordos voluntários públicos são firmados entre a empresa ou grupo de empresas e um agente ambiental governamental com objetivo de resolver problemas ambientais específicos de maneira colaborativa.

Diversos elementos podem motivar as empresas a atuar de forma socialmente responsável, como pressões externas, forma instrumental ou princípios. Essas pressões externas se referem, por exemplo, às legislações ambientais, ao aumento da exigência por parte dos consumidores, à atuação dos sindicatos, entre outros.

A forma instrumental é um meio de obtenção de algum benefício ou vantagem. Uma forma de benefício é o incentivo fiscal concedido pelo governo. Porém, um percentual muito pequeno de empresas atua no apoio à cultura, destacando como uma das principais 
justificativas as leis de incentivo e sua baixa abrangência que atendem apenas empresas que adotam o regime de lucro real e que se candidatam ao benefício da renúncia fiscal - sendo que para tanto é necessária regularidade com os deveres tributários presentes no emaranhado de leis existentes. Outra dificuldade é devida à burocracia para a candidatura ao benefício.

Portanto, nesses casos, a adoção da prática da Responsabilidade Social Empresarial (RSE) acontece pelo fato de as empresas entenderem o quanto ela é benéfica para a marca, independentemente dos incentivos governamentais.

A motivação por princípio é a que melhor garante uma continuidade de investimentos sociais a longo prazo por se tratarem de valores inseridos na cultura da organização.

O Relatório de Sustentabilidade é uma ferramenta transparente em que as empresas apresentam seus indicadores sociais, econômicos e ambientais.

O conteúdo desses relatórios contém informações sobre as práticas e os resultados alcançados nas áreas de meio ambiente, geração de empregos, arrecadação de impostos, eliminação da discriminação do trabalho, apoio à educação, combate ao trabalho forçado e infantil, saúde e segurança do trabalho e outras questões relacionadas. O esforço para relatar o desempenho nessas dimensões permite que a empresa enxergue a sua contribuição atual em relação aos objetivos do desenvolvimento sustentável e estabeleça objetivos para o futuro. (BARBIERI, 2016, p. 236)

Uma maneira de promover a Responsabilidade Social Empresarial é o Investimento Social Privado (ISP), que é o uso que as empresas fazem dos seus recursos privados voltados para fins públicos promovendo a transformação e desenvolvimento social, gerando o bem comum. Os recursos podem ser de fins financeiros, humanos, técnicos, entre outros.

As OSCIPS (Organizações da Sociedade Civil de Interesse Público) são entidades sem fins lucrativos com atuações que dinamizam as relações econômicas e sociais. O Instituto Ethos de Empresas e Responsabilidade Social é uma OSCIP que tem como objetivo mobilizar e apoiar empresas em uma gestão de negócios com responsabilidade social, para uma sociedade mais igualitária e sustentável. 
Para cumprir sua missão, o Instituto Ethos fornece ferramentas de práticas de gestão além de ambientes para troca de informações e experiências entre as empresas. Uma das ferramentas incentivadas é a do benchmarking, para o compartilhamento das melhores práticas sustentáveis.

International Organization for Standardization (ISO) ou Organização Internacional para Padronização é uma entidade não governamental que padroniza e normatiza produtos e serviços, de forma a promover melhorias.

A ISO 14000 consiste em normas e diretrizes de gestão ambiental, seu principal objetivo sendo o de proteção dos recursos naturais. Para que uma empresa obtenha seu certificado ISO 14000 e demonstre seu comprometimento, é necessário cumprir com a legislação ambiental em vigor no seu país e treinar seus funcionários sobre as normas para que estejam presentes em todos os processos. Outro fator é a busca por melhores soluções que diminuam os impactos ambientais.

A norma ISO 26000 apresenta diretrizes sobre a responsabilidade social para empresas de diferentes portes - na implantação de práticas e desenvolvimento de políticas internas com foco na sustentabilidade empresarial. A participação das empresas ocorre de forma voluntária por reconhecerem a importância de sua adoção, já que não apresenta certificado.

\section{Metodologia}

Considerando-se o critério de classificação de pesquisa proposto por Vergara (2016), quanto aos fins trata-se de uma pesquisa descritiva, pois pretende expor as características socioculturais em empresas brasileiras de cosméticos.

Quanto aos meios, trata-se, ao mesmo tempo, de uma pesquisa bibliográfica e de um estudo de caso. Classifica-se como pesquisa bibliográfica pois será desenvolvida com o uso de material acessível ao público em geral, como livros, artigos e informações institucionais publicadas pelas empresas; refere-se também a um estudo de caso porque focará no modelo de responsabilidade social da Natura. 
Universo e amostra

Pelo critério de acessibilidade, a Natura foi escolhida para compor a amostra devido à sua transparência na divulgação de relatórios anuais contendo informações referentes às suas atividades e negócios, o que inclui práticas voltadas à responsabilidade social.

\section{Coleta de Dados}

Os dados serão coletados por meio de pesquisa bibliográfica em livros, dissertações, artigos e relatórios de sustentabilidade com dados pertinentes ao assunto.

\section{Tratamento dos dados}

Os dados trabalhados são, essencialmente, levantados por terceiros e trazem argumentações, interpretações, análises e conclusões desses autores. Portanto, serão extraídos elementos práticos de análise por meio de observação ativa.

\section{Limitações do método}

A principal limitação da pesquisa é a da abrangência, que se aprofundará somente no caso da Natura, deixando à parte outras empresas.

Outro fator limitante está nas eventuais dificuldades para conseguir autorização para acessar documentos e informações internas das empresas, que podem tratar-se de dados sigilosos.

\section{O caso da empresa natura}

No ranking de maiores consumidores de produtos de beleza e higiene, o Brasil se encontra em quarto lugar - ficando atrás apenas 
dos Estados Unidos, China e Japão. Em 2018, representou 6,2\% do consumo mundial do setor e o seu crescimento real representa um aumento de 1,7\% se comparado a 2017.

De acordo com a Associação Brasileira da Indústria de Higiene Pessoal, Perfumaria e Cosméticos (ABIHPEC, 2017), existem no Brasil 2.718 empresas atuando nesse mercado. Desse total, quinze são de grande porte.

A Natura é a maior em participação desse segmento no Brasil, com 11,9\% do market share no setor de beleza e cuidados pessoais. Em maio de 2019, a Natura confirmou a aquisição da marca Avon, que ocupa o sétimo lugar no ranking de participação do segmento, com 4,7\% das vendas.

Para mostrar como se coloca a responsabilidade social em prática em uma empresa de cosmético, este estudo utiliza como modelo a Natura, a qual é uma grande empresa focada na responsabilidade social.

\section{A Natura}

A Natura foi fundada em 1969 por Luiz Seabra já com a missão de proporcionar o bem-estar do indivíduo consigo mesmo e com o mundo ao seu redor. Faz parte do seu compromisso gerar um impacto positivo para a sociedade e para o meio ambiente.

Atualmente, a Natura está presente em oito países - Argentina, Brasil, Chile, Colômbia, Estados Unidos, França, México e Peru.

Em 1979, desenvolveu a linha 'Chronos', a primeira no mundo com seu portfólio orientado por idades para atender as mais diversas necessidades. É uma linha que busca desconstruir preconceitos e promover a autoestima, inovando no tratamento antissinais ao trazer para a América Latina uma tecnologia que atua diretamente na comunicação entre as células.

A marca Natura Mamãe e Bebê foi lançada em 1993 com a ideia de promover o vínculo maternal entre mãe e filho. Uma contribuição da marca foi a criação do talco em creme, porque o talco tradicional gerava acúmulos na via respiratória - o que podia ocasionar em irritação. Em 2017, quebrou estereótipos com a linha 'Papai e Bebê' para ressaltar a importância da participação do pai no crescimento e desenvolvimento da criança. Os produtos dessa linha passaram a ser $100 \%$ veganos e podem ser usados desde o primeiro dia de vida do recém-nascido. 
Em 1983, tornou-se a primeira marca de cosméticos brasileira a oferecer refil de seus produtos, contribuindo para a redução de impacto ambiental. Em 1995, criaram, em parceria com a Fundação Abrinq, a única linha de produtos não cosméticos, chamada 'Crer para Ver', cujo lucro obtido é investido na educação pública.

Foi nomeada pela primeira vez como Empresa do Ano em 1998 pela revista Exame. Lançou em 2000 a linha 'Ekos', que enaltece a biodiversidade brasileira na sua formulação. Foi através da linha 'Ekos' que a Natura lançou a primeira embalagem refil de perfume com frasco composto por material $100 \%$ reciclado, o que reduziu as emissões de gases do efeito estufa em $72 \%$.

A linha 'Ekos' espelha a proposta que a Natura desenvolveu desde o começo - de aliar o compromisso de sustentabilidade ao de bem-estar. Os produtos da linha, que utilizam recursos da biodiversidade brasileira, passam por dupla verificação, certificada pela União para o BioComércio Ético (UEBT).

Como forma de reconhecer e premiar os seus principais parceiros estratégicos, a Natura possui o Programa QLICAR (Qualidade, Logística, Inovação, Competitividade, Ambiental, Social e Relacionamento), iniciado em 2003. Trata-se de um programa corporativo que avalia o desempenho e as melhores práticas dos seus fornecedores, conforme indicadores pré-estabelecidos. O prêmio acontece anualmente e é dividido em diversas categorias, abrangendo fornecedores de matéria prima até os de serviços.

Receberam em 2004 a certificação ISO 14001, um Sistema de Gestão Ambiental que possibilita as organizações a desenvolverem práticas sustentáveis.

Em 2005 iniciou-se o Movimento Natura, um programa que engaja consultores de todo o Brasil em ações socioambientais e de cidadania. $\mathrm{O}$ Movimento Natura conecta projetos de transformação social a pessoas dispostas a se voluntariar. As ações promovidas seguem os seguintes critérios: já estão em processo de desenvolvimento, apresentam impacto social e/ou ambiental coletivo e combinam com as habilidades da rede. Para reafirmar esse compromisso, em 2010 surgiu o Prêmio Acolher, que promove incentivos financeiros e técnicos para projetos sociais de consultores em suas comunidades. 
A empresa também proibiu os testes de produtos e ingredientes em animais em 2006, além de não comprar ingredientes ou insumos que foram testados em animais. A partir disso, desenvolveram uma plataforma de pesquisas e testes alternativos in vitro. Todos os produtos do seu portfólio são $100 \%$ vegetarianos, sendo permitidos apenas ingredientes derivados de animais, como a cera de abelha. Já os produtos veganos - que excluem totalmente ingredientes de origem animal representam $80 \%$ do total. A Natura é a primeira empresa da América Latina a ter a certificação Cruelty Free International e é certificada pela People for the Ethical Treatment of Animals (PETA).

Ainda em 2006, fechou uma parceria com a Associação de Produtores de Boa Vista e a Associação das Ervateiras do Mercado Vero-Peso, as duas fundadas no estado do Pará, para remunerar o conhecimento nacional difuso. Foi a pioneira a fazer um acordo dessa natureza.

Visando uma maior transparência das informações, foram pioneiros ao implementar, em 2007, uma tabela ambiental em seus produtos apresentando seis indicadores da origem de suas matérias-primas e embalagens.

O Cocriando Natura é uma rede de colaboração para inovação lançada em 2013 que identifica desafios para serem resolvidos de maneira conjunta por voluntários que se interessarem pelo tema. A participação fica concentrada na fase inicial do desenvolvimento do projeto, pois a efetiva realização é implementada pela equipe interna da Natura. Os participantes com maior engajamento são reconhecidos através de pontos e recebem bonificações.

A linha SOU foi lançada em 2013 com produtos para cuidados diários que possuem preços mais acessíveis e embalagem que utilizam $70 \%$ menos plástico, uma solução sustentável para reduzir o impacto ambiental. Além disso, sua embalagem gera três vezes menos resíduos que as versões convencionais e emitem uma taxa de $\mathrm{CO} 260 \%$ menor.

Atualmente a Natura é líder no modelo de venda direta, formato de comercialização que une suas duas paixões: cosméticos e relações - por isso conta com uma grande rede de consultoras por todo o Brasil e em suas operações na América Latina, além de possuir 45 lojas próprias e estar presente em farmácias e lojas franqueadas. 
Desde 2014 a Natura possui certificação como Empresa B, uma iniciativa do movimento Sistema $\mathrm{B}$, que reconhece empresas que priorizam resultados econômicos tanto quanto os socioambientais.

Em 2017 surgiu o grupo Natura \& Co., com a junção da Natura à The Body Shop e à Aesop. O desempenho socioambiental é incluso em sua visão integrada de gestão, portanto procura ações estratégicas que aprimorem a eficiência em seus processos e portfólio de produtos.

Preocupados com a saúde da rede de consultores, desde 2017 a Natura conta com um programa que oferece serviços de saúde para a consultora e um dependente. Através desse programa é possível obter descontos de até $60 \%$ em remédios, consultas e exames médicos.

Aconteceu em 2017 o lançamento do programa Nossa Gente, servindo como modelo de gestão de pessoas. O foco desse programa é na atração e retenção de colaboradores e na formação de gestores e líderes. O colaborador é visto como protagonista, recebe mais autonomia nos processos que desenvolve e feedbacks em tempo real, visando o autoconhecimento dos seus pontos fortes e quais pontos devem ser melhorados. A remuneração oferecida está acima da média do mercado, compartilhando os resultados da organização com os colaboradores. Anualmente é realizada uma revisão para identificar profissionais com o perfil e potencial para atingir cargos de liderança.

A sede administrativa da Natura (NASP) foi inaugurada em 2007 com foco no atendimento de consultores da empresa. Está localizada na zona prioritariamente industrial da cidade de São Paulo, em uma área de $29.700 \mathrm{~m}^{2}$, com capacidade para até 1.600 colaboradores. Ela surgiu através de um concurso de arquitetura promovido pela Natura em 2011, que selecionou o projeto desenvolvido pelo escritório Dal Pian Arquitetos Associados.

Recebeu em 2018 a certificação LEED (Leadership in Energy and Environmental Design).

\section{Espaço Natura Cajamar}

No ano de 2001 foi inaugurado, no município de Cajamar, o centro integrado de pesquisa, produção e distribuição de cosméticos 
mais avançado da América do Sul. Sua área de $70.000 \mathrm{~m}^{2}$ é composta por 12 edifícios interdependentes e quatro fábricas (perfumes, cremes, maquiagens e xampus).

O espaço foi construído visando o melhor aproveitamento de água, energia e ventilação. O modelo de climatização permite a troca do ar interno com o externo, o que é favorecido pela grande área natural ao redor da instalação - contribuindo também para a economia de água.

Painéis de captação de energia solar são utilizados por toda a fábrica e a água utilizada passa por tratamento em uma Estação de Tratamento de Efluentes para que possa ser reutilizada na irrigação de jardins, na lavagem da rua, em descargas e como reserva no sistema de incêndio.

\section{Natura Campus}

O Natura Campus é um programa criado em 2003 que promove a cooperação entre empresas e instituições de ciências e tecnologia, incentivando a inovação e criação de valor compartilhado através da construção de relacionamento.

O foco está no desenvolvimento de inovações disruptivas, ou seja, que visam transformar o mercado.

No espaço acontecem workshops - atividade que reúne grupos para compartilharem conhecimentos e discutirem sobre novas oportunidades e temas de interesse comum.

Em uma parceria com a Coordenação de Aperfeiçoamento de Pessoal de Nível Superior (Capes) acontece a cada dois anos o Prêmio Capes - Natura Campus de Excelência em Pesquisa, com o objetivo de incentivar pesquisas que gerem impacto para o desenvolvimento da ciência e da tecnologia com foco sustentável e na biodiversidade.

O Portal Natura Campus conta com um espaço de recebimento de novas ideias e oportunidades percebidas por pesquisadores e empreendedores do mundo todo. Com base nas sugestões recebidas, a Natura tem o papel de ser mediadora entre as áreas de interesse da organização e o processo inovação. 


\section{Programa Carbono Neutro}

O Programa Carbono Neutro foi estruturado pela Natura em 2007, com a meta de reduzir a emissão de gases do efeito estufa (GEEs) em toda a cadeia produtiva, começando na extração da matéria-prima e indo até o descarte das embalagens de seus produtos.

\section{Programa Amazônia}

Lançado em 2011, o Programa Amazônia trouxe iniciativas que visam unir a atuação institucional da Natura, a rica biodiversidade Amazônica e a competência da organização nos campos da ciência, tecnologia e inovação.

Com esse programa, a Natura pretende beneficiar 10 mil famílias até 2020 e alcançar 30\% do total de insumos originados da região PanAmazônica. Uma das metas, a de gerar R $\$ 1$ bilhão em volume de negócios no Pan-Amazônia, foi atingida em 2018 - com um valor que ultrapassou R $\$ 1,5$ bilhão.

As famílias fornecedoras da sociobiodiversidade são $81 \%$ de comunidades da região Amazônica.

A Natura tem fortalecido a pesquisa, tecnologia e desenvolvimento para os ingredientes naturais. Baseia-se na biomimética, área da ciência que usa a natureza como inspiração para encontrar novas estratégias e soluções.

Dentre os principais objetivos desse programa, a geração de renda e inclusão social da comunidade regional estão entre as principais.

Tendo em vista o fortalecimento institucional, a Natura investe em parcerias que visam alavancar instituições e comunidades locais, fomentando a economia baseada na natureza.

\section{O Ecoparque}

O Ecoparque está desde 2014 localizado em Benevides (PA) e conta com a produção de $80 \%$ dos sabonetes da Natura. 
Seu projeto foi pensado para ser um empreendimento ecologicamente correto e é baseado na simbiose industrial, que se trata de uma cadeia produtiva integrada promovendo a interação entre indústrias de diferentes áreas de atuação, mas com interesses em comum e necessidades complementares. Essa rede de cooperação permite o compartilhamento e reaproveitamento de matérias primas, energia, efluentes industriais e materiais de descarte. Esse compartilhamento é mutuamente rentável e gera uma maior eficácia nos processos.

O Ecoparque foi instalado de modo a permitir a reutilização de água da chuva, aproveitamento de ventilação através de geotermia e iluminação natural. Os efluentes passam por um tratamento chamado jardins filtrantes, uma alternativa inovadora a partir de raízes de plantas. São disponibilizados carros elétricos para mobilidade de colabores e visitantes dentro do complexo e o uso de bicicletas é incentivado.

Uma parte significativa da equipe é formada por jovens, muitos na sua primeira oportunidade no mercado de trabalho.

A Natura busca engajar suas unidades em iniciativas que alavanquem o desenvolvimento humano e social da região. Em Benevides, uma das iniciativas escolhidas foca na prevenção e combate à violência doméstica, oferecendo auxílio jurídico e acolhimento social e psicológico.

\section{Instituto Natura}

O Instituto Natura é uma Organização da Sociedade Civil de Interesse Público (OSCIP), que tem como fundamento a transformação social através da educação.

Umas das suas iniciativas é a linha de produtos 'Crer para Ver', que investe seu lucro em ações de promoção da educação pública e viabilizam que os consultores e sua família possam fazer cursos presenciais ou de ensino à distância de graduação, pós-graduação, profissionalizantes e de idiomas. Alguns cursos são gratuitos e outros oferecem descontos. 


\section{Natura Musical}

Atuando desde 2005, o Programa Natura Musical impactou diretamente mais de 260 mil pessoas até 2018. O foco do projeto é a valorização e o estímulo à música brasileira.

Os projetos são selecionados por meio de editais públicos com base na avaliação de curadores da área da música. São selecionados cinquenta artistas ou bandas que estão em desenvolvimento ou em fase de renovação da carreira.

Para os aportes são utilizados recursos próprios e de incentivo da Lei Rouanet, além do apoio de leis estaduais de incentivo à cultura com recursos do ICMS nos estados de Minas Gerais, Bahia, Pará, Rio Grande do Sul e São Paulo.

Em 2017 foi inaugurada a Casa Natura Musical, localizada em São Paulo (SP). Ela foi idealizada para receber as mais diversas vertentes da música nacional e sua programação conta com grandes nomes brasileiros e revelações.

\section{Visão de Sustentabilidade 2050}

A Visão de Sustentabilidade 2050 é um documento da Natura que estabelece metas a serem alcançadas e diretrizes a serem seguidas, além de compromissos e ambições para 2020 - o que compromete a sua atividade em três pilares: marcas e produtos, rede (públicos com os quais se relaciona) e gestão organizacional. As metas são estabelecidas visando gerar um impacto positivo para a sociedade, tornando-a um lugar melhor.

Em relação às marcas e produtos, a utilização de tecnologia e inovação mantém a busca por design e processos de fabricação com impacto socioambiental positivo. Sua produção e distribuição será guiada pela linha da ecoefetividade, praticando a reutilização de materiais e propiciando um impacto positivo na cadeia de valor e desenvolvimento da comunidade local. Seus compromissos e resultados serão divulgados de forma transparente.

As submarcas da Natura demonstram que essas práticas já estão sendo estimuladas. Exemplo disso é a linha 'Ekos', com a forte 
valorização da biodiversidade, e a linha SOU, que incentiva o consumo consciente agregando ecoeficiência e ecodesign nos seus produtos.

A escolha da matéria-prima deve considerar a sua pegada ambiental e social: o uso de ingredientes renováveis e vegetais, desenvolvidos a partir da biodiversidade, serão priorizados e incentivados. As embalagens devem ser desenvolvidas com o princípio de ecodesign, apoiando-se na redução de materiais, reciclabilidade, aderência a refis e outras formas de reuso, atingindo um ciclo de vida fechado.

A vegetalização dos produtos já está sendo adotada pela Natura os sabonetes são $100 \%$ com utilização de produtos vegetais, medida gradativamente expandida para outros produtos do seu portfólio para que os ingredientes não renováveis sejam substituídos. Em 2018, o índice de vegetalização total teve representação de $82 \%$.

A Natura foi pioneira ao implementar produtos cosméticos em refil e tem feito esforços para que sejam utilizados em diferentes categorias de produtos. Em 2014, lançou no mercado o primeiro refil de perfume $100 \%$ reciclado.

Outro objetivo é o da eficiência energética, utilizando energia renovável em suas operações no Brasil. Utilizam etanol nas caldeiras das fábricas situadas em Cajamar (SP) desde 2011, e em 2012 instalaram em Benevides (PA) uma caldeira movida à biomassa, em substituição ao óleo diesel. Em relação ao transporte, foi a primeira empresa a adotar ônibus fretado e carretas movidas a etanol, além de veículos elétricos que realizam entregas aos consultores.

A ambição para 2050 é de que 50\% dos resíduos gerados por embalagens sejam coletados e obtenham descarte correto para que sejam reciclados. Um sistema de logística reversa deve ser implantado para coletar o material após o uso dos consumidores. Para que isso seja possível, a Natura tem adotado uma gestão de resíduos baseada na metodologia de inventário para quantificar o volume de resíduos nos processos internos, na distribuição das embalagens e no descarte pós-consumo. Através dessa mensuração, reúne diretrizes que devem ser usadas em cada fase.

O compromisso estabelecido pela Natura em relação à água é o de reduzir a poluição nas operações internas e nas desenvolvidas por fornecedores, implementando tecnologias de tratamento de efluentes para reutilização da água. 
Com os fornecedores, o compromisso é de garantir a rastreabilidade em todos os elos da cadeia de valor, certificando-se da origem da matéria-prima através de uma rigorosa verificação socioambiental.

O segundo pilar, denominado "nossa rede", visa estimular o desenvolvimento social e humano em suas relações, investindo em ações educacionais e de empreendedorismo. Essa iniciativa está em desenvolvimento através do projeto Cocriando, implementado em 2013, que realiza interações virtuais e presenciais abertas para quem quiser compartilhar novas ideias que contribuam para o desenvolvimento de produtos e conceitos.

O terceiro pilar, "gestão e organização" diz respeito ao equilíbrio e harmonia entre aspectos sociais, econômicos, culturais e ambientais incorporados aos valores e processos da organização.

No modelo organizacional, o foco está em uma gestão mais horizontal em que os colaboradores atuem de forma mais interativa e participativa. Outro ponto positivo desse modelo de gestão é a distribuição de renda mais equilibrada para todos. A prioridade para 2020 é a de aumentar a gestão integrada com foco no tripé da sustentabilidade (social, ambiental e financeiro).

Com o governo e a sociedade, o comprometimento é de proporcionar debates públicos focados no desenvolvimento sustentável da população e participar na construção de políticas públicas que envolvam os temas em discussão na sua visão de sustentabilidade, além de manter relacionamentos com outras instituições e organizações de propósitos comuns, com diálogos baseados na transparência e confiabilidade.

A Natura se compromete a divulgar de forma transparente as práticas adotadas, os resultados obtidos e os impactos causados de forma a intensificar vínculos sustentados por confiança.

\section{Considerações finais}

Com o aumento da tendência do consumo consciente e o constante avanço tecnológico, estratégias de responsabilidade social se tornam fundamentais para que as empresas se mantenham competitivas no mercado. 
Empresas com posicionamento ético e ações de responsabilidade social melhoram a credibilidade da marca e a imagem pública da empresa. Isso é decorrente da exigência de que a empresa abranja um propósito maior, se preocupando com o impacto gerado por toda a sua cadeia produtiva e gerando benefícios para a sociedade.

O impacto de cada produto é avaliado desde a produção, da extração dos produtos na natureza e da comunidade que atua cultivando os insumos.

A Natura é um exemplo rentável de como as empresas de cosméticos podem implementar a responsabilidade social no seu modelo de negócios e em seus produtos. A sustentabilidade e a cidadania empresarial estão incorporadas em sua marca e são reconhecidas pela sociedade, fator favorável para sua reputação.

Com sua visão de sustentabilidade, a Natura assume diversos compromissos e ambições, norteando sua atuação empresarial através de diretrizes de longo prazo para o ano de 2050.

Além do seu discurso, a Natura coloca em prática a gestão sustentável por todo o ciclo de vida organizacional - prova disso são as certificações que possui, destacando e reconhecendo seu compromisso com o desenvolvimento sustentável.

A inovação está sempre presente nos seus produtos, embalagens e processos, para que sejam adotadas tecnologias sustentáveis e mudanças constantes em suas práticas, adotando as melhores soluções para uma crescente transformação.

O alicerce fundamental são os valores em seus processos e relações. Sua razão de ser é o bem-estar - estar bem, que propõe a harmonia de sentimentos e relações do indivíduo consigo, com os outros e com a natureza.

Suas embalagens e produtos são elaborados pensando no impacto que gerarão na sociedade e na natureza. Por isso, investe em embalagem de refil, materiais reciclados, vegetalização das fórmulas, ingredientes renováveis e valorização da biodiversidade.

Pensando no desenvolvimento dos seus consultores, a Natura promove o incentivo à educação por meio de recursos adquiridos pela venda de produtos da linha 'Crer para Ver'. O Prêmio Acolher é uma iniciativa que engaja e garante suporte técnico e financeiro para que os consultores desenvolvam projetos sociais nas comunidades em que moram. 
A participação da cadeia de fornecedores é impulsionada, contando com um programa de desenvolvimento e reconhecimento que concede anualmente uma premiação aos melhores fornecedores com base na sua atuação em aspectos de inovação e responsabilidade socioambiental. A Natura garante a transparência e origem de seus produtos por um processo de rastreabilidade dos insumos de fabricantes diretos, e tem como compromisso maximizar, até 2020, a rastreabilidade para os demais elos da cadeia de valor.

Cajamar (SP) acolhe um importante centro de pesquisa e tecnologia da Natura, que conta com um avançado sistema para permitir o melhor aproveitamento de água, energia e ventilação. Em Benevides (PA) está instalado o Ecoparque, uma unidade industrial estruturada para ser ecologicamente correta, baseada na cadeia produtiva integrada.

O Programa Natura Musical é uma importante contribuição para a cultura, com valorização à música brasileira. Seus projetos contribuem para a representatividade das mulheres e minorias no mercado musical.

O Instituto Natura demonstra o compromisso da Natura com a educação, atuando junto a políticas públicas para gerar mudanças no cenário da educação pública brasileira.

Conclui-se que é imprescindível que a organização tenha a responsabilidade social presente nos seus valores e em sua filosofia, apostando no desenvolvimento harmônico de aspectos sociais, ambientais e econômicos.

\section{Referências}

BARBIERI, José Carlos. Gestão ambiental empresarial: conceitos, modelos e instrumentos. São Paulo: Saraiva, 2016.

OLIVEIRA, José Antonio Puppim de. Empresas na sociedade: sustentabilidade e responsabilidade social. Rio de Janeiro: Campus Elsevier, 2013.

PASSOS, Elizete. Ética nas organizações. São Paulo: Atlas, 2012.

PENIDO, Henrique Rocha. $\mathbf{O}$ papel das organizações internacionais na garantia do desenvolvimento sustentável: a releitura da atuação das sociedades empresárias. Rio de Janeiro: Editora GZ, 2017. 
TENÓRIO, Guilherme Fernando. Responsabilidade social empresarial: teoria e prática. Rio de Janeiro: FGV, 2004.

VERGARA, Sylvia Constant. Projetos e relatórios de pesquisa em administração. 16. ed. São Paulo: Atlas, 2016. 



\title{
Reflexões sobre o conceito de ergonomia e a percepção de retorno para as organizações e funcionários
}

\author{
Júlio César Isaguirre \\ Renata Schirrmeister
}

\begin{abstract}
Resumo
A ergonomia busca a melhoria da saúde e do bem-estar do trabalhador, com retornos econômicos e sociais - tanto para a organização quanto para funcionários. O objetivo principal deste estudo foi analisar as percepções de resultado de ações ergonômicas por parte dos gestores e funcionários em uma organização multinacional brasileira do ramo de cosméticos, considerando suas contribuições nos âmbitos individual, social e organizacional. Este estudo caracteriza-se como exploratório, com estratégia de estudo de caso (YIN, 2005), utilizando-se métodos qualitativos e quantitativos. Foi realizada uma entrevista com o ergonomista, que é gestor na organização e, em seguida, um levantamento quantitativo com empregados sobre as percepções dos impactos das ações. Os resultados encontrados foram além da expectativa inicial, sendo possível perceber que a ergonomia é uma ciência bastante ampla e que, se bem aplicada pela organização, contribui com melhorias para a qualidade de vida no trabalho, a dignidade humana e o bem-estar individual e coletivo. Como futuros administradores, os resultados obtidos nos demonstram que é possível desenvolver uma visão mais ampla e humanista na gestão de empresas, em que a consciência do valor do trabalho e das pessoas traz resultados inestimáveis tanto para as organizações quanto
\end{abstract}


para a sociedade, melhorando a qualidade de vida das pessoas, proporcionando o envelhecimento saudável e contribuindo para um melhor clima organizacional que possibilita que a empresa torne-se mais competitiva e inovadora.

Palavras-chave: Ergonomia. Qualidade de Vida no Trabalho. Desempenho Organizacional.

\section{Introdução}

A ergonomia é uma antiga demanda dos movimentos dos trabalhadores e também dos empresários, notadamente com o Taylorismo, na Escola da Administração Científica. Quando surgiram os primeiros psicólogos do trabalho, na primeira metade do século XX, eles possuíam como foco a prevenção da fadiga e a melhoria do desempenho laboral. Para os movimentos dos trabalhadores, a ergonomia trata-se de uma forma de prevenção de doenças e promoção da qualidade de vida no trabalho; para os empresários, um caminho para o aumento da eficiência produtiva.

Em termos formais, ela existe desde 1949, com a Ergonomics Research Society (ERS), na Inglaterra. Em seguida, foram criadas as Human Factors Society (HFS) - que atualmente chama-se Human Factors and Ergonomics Society (HFES) - e a International Ergonomics Society (IES) em 1959, nos Estados Unidos. Já na França, ela veio um pouco depois, em 1963 com a Societé d’Ergonomie de Langue Française (Self). (ABRAHÃO et al., 2009).

No Brasil, a Associação Brasileira de Ergonomia (Abergo) foi criada em 13 de julho de 1983 junto ao Instituto Superior de Estudos e Pesquisas Psicossociais da Fundação Getúlio Vargas por Itiro lida, Anamaria de Moraes, Franco Lo Presti Seminério e Ued Martins Manjub Maluf (MORAES, 1999 apud LUCIO et al., 2010).

A Abergo utiliza o conceito da Associação Internacional de Ergonomia (IEA), de agosto de 2000, que é o seguinte:

A ergonomia (ou fatores humanos) é uma disciplina científica relacionada ao entendimento das interações entre os seres humanos e outros elementos ou sistemas, e à aplicação de teorias, princípios, dados e métodos a projetos a fim de otimizar o bem estar humano e o desempenho global do sistema (ASSOCIAÇÃO BRASILEIRA DE ERGONOMIA, 2020, s/p). 
Os campos de ação da ergonomia são (lbid):

- Ergonomia física: com foco na anatomia humana, fisiologia e biomecânica, abrangendo o estudo da postura no trabalho, manuseio de materiais, movimentos repetitivos, distúrbios musculoesqueléticos relacionados ao trabalho, projeto de posto de trabalho, segurança e saúde.

- Ergonomia cognitiva: com foco nos processos mentais (percepção, memória, raciocínio e resposta motora), abrangendo o estudo da carga mental de trabalho, tomada de decisão, desempenho especializado, interação homem-computador, stress e treinamento.

- Ergonomia organizacional: foca nos sistemas sociotécnicos, como estruturas organizacionais, políticas e processos, abrangendo comunicações, projeto de trabalho, organização temporal do trabalho, trabalho em grupo, projeto participativo, novos paradigmas do trabalho, trabalho cooperativo, cultura organizacional, organizações em rede, teletrabalho e gestão da qualidade.

Os aspectos ergonômicos do trabalho se referem a uma formação mais especializada, com clara aplicação na prevenção de doenças e promoção da qualidade de vida dos trabalhadores - contribuindo para a dignidade humana e o bem-estar individual e coletivo, bem como para o desenvolvimento das organizações e da sociedade.

Como aspecto social da ergonomia temos a sua contribuição para a qualidade de vida dos indivíduos e melhoria nas relações do trabalho. Sznelwar (2015) afirma que muitas vezes o diagnóstico de doenças oriundas do trabalho é tardio e as sequelas, na maioria das vezes, são irreversíveis.

Como recorte de estudo foi delineada a seguinte pergunta: como a ergonomia colabora para a melhoria do desempenho individual e organizacional? O objetivo geral foi analisar as percepções de resultado de ações ergonômicas em uma organização multinacional brasileira do ramo de cosméticos, considerando suas contribuições aos âmbitos individual, social e organizacional.

Os objetivos específicos consistiram em estudar o conceito de ergonomia, identificar os investimentos realizados pela empresa em ações ergonômicas, avaliar como gestores e colaboradores percebem retornos desses investimentos e identificar de que maneira eles contribuem para o desenvolvimento individual, social e organizacional. 
Este artigo está estruturado da seguinte maneira: introdução, onde foram apresentados o conceito de ergonomia, seu surgimento e importância e o recorte de pesquisa; referencial teórico, em que temos um aprofundamento dos aspectos levantados na introdução; metodologia do estudo; resultados da pesquisa de campo e conclusões.

\section{Referencial teórico}

Ramazzini (2000), considerado o pai da medicina do trabalho, foi o primeiro a publicar estudos e observações sobre o tema na obra "As doenças dos trabalhadores", que descreveu as pessoas que trabalhavam sentadas como operários sedentários - os "artesãos de cadeira" sofriam de doenças especiais próprias de suas atividades. $\mathrm{O}$ autor também comenta que a postura ao sentarem-se de forma curvada para execução dos trabalhos causava deformações em suas vértebras dorsais, que as deixavam mais salientes e, mesmo fora do ambiente de trabalho, mantinham a curvatura do corpo (RAMAZZINI, 2000, p. 173).

Porém, à época, ainda não contavam com uma ciência para indicar tratamentos e/ou medidas de prevenção - e, mesmo diante do conhecimento que possuíam, seriam ineficazes medidas preventivas enquanto não fossem tomadas medidas preventivas para as causas das doenças (RAMAZZINI, 2000, p. 174).

Partindo dessa observação, desde 1700, ano em que o livro foi escrito, verifica-se que as atividades rotineiras dos trabalhadores já ocasionavam males característicos e semelhantes. Ao longo dos anos, essa ciência se desenvolveu chegando à denominação atual de ergonomia.

Segundo Vidal (2003, p. 35), as ações ergonômicas envolvem vários aspectos relacionados às pessoas e suas atividades laborais. Um dos campos de estudo da ergonomia é a ergonomia física, que estuda as limitações das pessoas diante do seu posto de trabalho em cada tipo de atividade - considerando-se que essa relação pode interferir de forma benéfica ou não no desempenho do trabalhador.

Além dos aspectos da ergonomia física, a ergonomia também se alimenta da abordagem cognitiva do trabalho (denominada ergonomia cognitiva), que está diretamente relacionada à tomada de 
decisão - seja ela individual ou coletiva - do trabalhador, que torna-se responsável pela execução da organização das atividades que desenvolve (VIDAL, 2003, p. 36).

Esses campos de estudo da ergonomia física a ergonomia cognitiva, associados aos aspectos organizacionais da empresa, corroboram sua evolução e seu conhecimento sobre os aspectos complexos da ergonomia; porém, não devem ser analisados de forma isolada, pois não refletiriam a complexidade real do trabalho (VIDAL, 2002, p. 16).

De acordo com o manual do Centro de Educação à Distância (CEAD, 2015, p. 11), o conceito de ergonomia possui três dimensões:

A ergonomia física tem por objetivo identificar os riscos de lesões musculoesqueléticas por meio da observação das reações do organismo dos trabalhadores ao layout dos postos de trabalho, aos esforços biomecânicos realizados para o transporte manual de cargas e às demandas psicológicas diante dos desafios para a execução das atividades laborais.

A ergonomia cognitiva (ou engenharia psicológica) observa as interferências causadas na realização das atividades do trabalhador em seu ambiente ou posto de trabalho ante demandas que exijam raciocínio, cognição, atenção, coordenação motora e experiência motora.

A ergonomia organizacional está intimamente relacionada à macroergonomia, pela qual são avaliadas todas as variáveis existentes decorrentes da relação hierárquica e das muitas formas de organização dos processos de trabalho. A macroergonomia é justamente um dos elementos que interagem na conexão empregado-empresa, pois estes não poderiam ser conectados diretamente. Segundo Delwing (2007, p. 27), "a macroergonomia é uma subdisciplina reconhecida da ergonomia que trata da interface ser humano-organização".

À medida que esses elementos são trabalhados tanto na ergonomia quanto na conscientização de todos os envolvidos, observa-se os resultados positivos, já que a macroergonomia auxilia o ergonomista com princípios como a participação, flexibilização, flexibilidade, otimização conjunta, projeto conjunto, melhoria contínua dos processos e harmonização do sistema (HERNDRICK e KLEINER, 2006, apud DELWING, 2007, p. 27).

As mudanças são sempre necessárias - faz parte da evolução. Uma empresa precisa evoluir para continuar participativa; porém, empresas são constituídas de pessoas - e pessoas tendem a ser 
resistentes às mudanças. Portanto, surge a necessidade de analisar cada trabalhador e mostrar que com a participação de todos é possível implantar as mudanças necessárias por meio da observação contínua do trabalhador e o seu trabalho, com foco em postura, movimentos e queixas, forma como se comunica e processos mentais que os governam. Como são influenciados pelo ambiente ou pela organização e os mecanismos psicológicos que os afetam, somente assim é possível "adaptar o trabalho ao trabalhador e não o trabalhador ao trabalho", que é o objetivo principal da ergonomia (Borges Filho, 2014 apud CEAD, 2015, p. 6).

As definições sobre ergonomia se referem sempre a uma relação entre as pessoas e o trabalho que realizam, bem como à relação entre máquinas e equipamentos e o trabalhador - sem desconsiderar o ambiente aonde isto ocorre. Essas relações podem ocasionar problemas que, de acordo com a Ergonomics Research Society, podem ser evitados ou sanados aplicando-se os conhecimentos do ergonomista em anatomia, fisiologia e psicologia (PEQUINI, 2005 apud CEAD, 2015 p. 6).

O que se pode observar é que a ergonomia é uma ciência bastante ampla e que está sempre em busca de adaptar os meios ao homem. Conforme Silva (2007, p. 16) a International Ergonomics Association (IEA) define a ergonomia como:

O estudo científico da relação entre o homem e seus meios, métodos e espaços de trabalho. Seu objetivo é elaborar, mediante a contribuição de diversas disciplinas científicas que a compõem, um corpo de conhecimentos que, dentro de uma perspectiva de aplicação, deve resultar em uma melhor adaptação ao homem dos meios tecnológicos e dos ambientes de trabalho e de vida.

De acordo com Rio e Pires (2001, p. 22-23), as ações ergonômicas constituem um aspecto fundamental para a excelência e competitividade organizacionais, além de melhorar a qualidade de vida presente e futura do trabalhador. Fatores como a otimização do trabalho, a motivação, treinamento e comprometimento, juntamente com a saúde dos 
trabalhadores, permitem às organizações terem no trabalho um fator estratégico diferencial.

Ainda conforme Vidal (2003, p. 36), a ação ergonômica se estabelece com foco na organização do trabalho, buscando descrever as atividades de trabalho como uma "resposta do operador às exigências da produção - o que constitui o campo da ergonomia situada, onde se modela a organização baseada na atividade e, mais ainda, qual o lugar da modelagem da atividade na concepção da organização". Para que se possa transformar as situações de trabalho e obter um bom resultado nas ações ergonômicas, é necessário garantir a participação de todos os atores envolvidos no processo (VIDAL, 2002, p. 50).

Portanto, o processo de ação ergonômica pode ser caracterizado pelos aspectos participativos, construtivistas e consensuais que atendam as demandas da organização na adoção de tecnologia física ou de gerenciamento para resolver os problemas que, em geral, são complexos em um ambiente relativamente nebuloso (VIDAL, 2002, p. 51).

Assim sendo, tanto a empresa quanto o ambiente, além das condições de trabalho, são determinantes e podem influenciar no resultado obtido e na retenção de talentos.

Segundo Cortella (2017, p. 61), "uma pessoa motivada faz algo decisivo: ela procura excelência". O trabalhador busca além de um bom ambiente de trabalho - busca algo que lhe dê satisfação e condições de adquirir os bens que necessita, mas não é somente isso; também busca o equilíbrio entre o trabalho e a vida pessoal para poder usufruir com aqueles que ama e da forma que mais gosta.

Souza e Rodrigues (2006) ressaltam que, quando são reconhecidas, as consequências negativas do trabalho podem estar na origem das demandas de ação do ergonomista e podem constituir a porta de entrada para um estudo ergonômico.

A iniciativa de implementar um programa de ergonomia na empresa pode partir da administração e/ou do departamento de saúde e segurança, em decorrência da ação de consultores externos ou de negociação com sindicatos (VIDAL, 2002).

De acordo com o manual do CEAD (2015, p. 13), "vimos que a Ergonomia é uma das mais importantes vertentes da saúde ocupacional e que vem 
ganhando cada vez mais terreno atualmente. Entretanto, há campos não relacionados diretamente ao trabalho, mas que exercem influência sobre ele e que também têm tido importância crescente, como os referentes à ecologia, ao meio ambiente, e à qualidade de vida urbana".

O excesso de trabalho pode afetar o desempenho tanto do trabalhador quanto da empresa. Cientes desses efeitos negativos e dos problemas que seriam acarretados tanto a funcionários quanto a quedas de produção, as organizações trataram de implantar ações ergonômicas que propiciem aos funcionários menor desgaste físico e mais equilíbrio mental (SOUZA, 2011, p. 15).

Durante as últimas décadas, a necessidade de participação tem sido desenvolvida pela ergonomia e em quase todos os programas é colocado que os representantes devem ser de todos os níveis. A maioria dos pesquisadores observa que a abordagem participativa é essencial para o sucesso do programa ergonômico.

A ergonomia surgiu com o intuito de sanar as reclamações referentes às condições de trabalho e, por um longo período, representou essas respostas, conferindo grandes avanços nas melhorias das condições de trabalho. Entretanto, ainda há campo para aprendizagem sobre o funcionamento do ser humano no trabalho (WISNER, 1994, p. 72).

As condições que envolvem um processo participativo podem ser divididas em categorias e dizem respeito tanto aos aspectos relacionados à organização e ao ambiente como aos aspectos relacionados aos indivíduos. São elas, segundo Loveridge (1990, apud SOUZA, 1994, p. 102): o potencial para a participação - que se refere a fatores estruturais e ambientais, como a tecnologia e a estrutura organizacional - e a propensão à participação, que se refere aos aspectos cognitivos motivacionais e culturais que formam os indivíduos mais ou menos propensos a se engajarem em processos participativos.

Como evolução da ciência da ergonomia, chegamos à Escola da Psicodinâmica do Trabalho (PDT), que foi desenvolvida pelo psicanalista Christophe Dejours na década de 1980 na França. Ele investiga os mecanismos de defesa dos trabalhadores diante de situações causadoras de sofrimento decorrentes da organização do trabalho, colocando o indivíduo como protagonista do próprio trabalho. Sobre o indivíduo como protagonista do trabalho: 
O trabalho não é exterior à pessoa, não é algo que lhe é conferido e que o sujeito deve apenas cumprir procedimentos, repetir gestos ou discorrer uma fala definida anteriormente. A ação do sujeito seria sempre construída por ele na sua atividade, portanto vivida e incorporada (SZNELWAR, 2015, p. 50-51).

\section{Metodologia}

Este estudo caracteriza-se como uma pesquisa exploratória com a finalidade de analisar, a partir da estratégia de estudo de caso (YIN, 2005) em empresa de grande porte, as percepções sobre as ações ergonômicas. Como objeto empírico, optamos em selecionar uma organização multinacional brasileira do ramo de cosméticos.

A pesquisa empírica foi realizada em uma das unidades da organização e compreendeu duas partes: a entrevista com um gestor responsável pela ergonomia na empresa e o levantamento quantitativo com os empregados.

Após a análise da primeira etapa, foi elaborado um questionário (com o auxílio do Google Forms) para ser aplicado nos empregados para complementar os dados. Os empregados foram selecionados pelo método bola de neve: um foi passando o link da pesquisa para o outro por um aplicativo de mensagens instantâneas (WhatsApp) de maneira informal.

Antes de aplicar o questionário, foi realizado um pré-teste com cinco pessoas para verificar necessidade de melhorias no instrumento e contar o tempo que se levaria para responder. Obtivemos 58 respostas (quase 3\% do total de empregados), com índice de confiabilidade em torno de $90 \%$.

\section{Resultados}

\section{Entrevista com o gestor}

Apresentamos abaixo a análise da entrevista sobre as respostas fornecidas pelo gestor, bem como trechos selecionados da transcrição de suas respostas. 
O entrevistado explicou que, de início, há a preocupação com a chamada ergonomia de correção - que é a melhoria do posto de trabalho com o objetivo de redução do absenteísmo - a partir das queixas e atestados médicos, identificando-se os motivos que levam as pessoas a terem dor, desconforto e afastamento médico. Evita-se, também, as situações jurídicas que impedem o desligamento, pois o trabalhador adquire estabilidade com a doença ocupacional. Além disso, procura-se aumentar a lucratividade por meio dessas ações.

[...] existem duas formas de você trabalhar com a ergonomia. Uma delas é a correção: você vai lá e corrige o posto de trabalho, faz adaptações... E a outra delas é na concepção: toda vez que eu for desenvolver algum projeto numa empresa - pode ser projeto de venda, projeto de produto final, projeto de fabricação de produto... Com a ergonomia da concepção, eu já tenho uma visão de implantar a ergonomia no projeto e, com isso, o meu custo vai ser muito menor; eu vou ter mais produtividade das pessoas porque o trabalho vai estar adaptado para elas $100 \%$ do tempo. [...] Se a taxa de ocupação é menor do que 40\%, você organiza o trabalho com vistas à ergonomia, e onde tinha duas pessoas trabalhando a $40 \%$, eu fico com uma trabalhando a $80 \%$. Ainda assim eu estou dando conforto para o trabalhador que não chegou a $100 \%$ dos gastos calóricos dele e ainda fiz a empresa reduzir em $50 \%$ o custo com trabalhador.

O absenteísmo também pode ser um fator causador de estresse, desgaste físico e desmotivador, porque expõe o trabalhador presente a uma sobrecarga de trabalho.

[...] sim! Imagine uma linha de produção que eu tinha que ter oito pessoas trabalhando e, por algum motivo, tem algum que falta, outro de férias, outro tal... Então estou com cinco pessoas lá na linha, a produção tem que ser igual! O gestor acaba não considerando essa redução da produtividade por conta do número de pessoas e exige dos cinco que façam a produção de oito. 
O treinamento revelou-se de grande importância, seja pelo revezamento de funcionários, seja pela conscientização de prevenção de fadiga e outros danos, seja pela criação de uma cultura de criação e gestão de novos procedimentos pelos próprios trabalhadores.

[...] na prática, a ergonomia é você entender a atividade do trabalhador. Algumas vezes as empresas ou o engenheiro de produção, por não entenderem a atividade do trabalhador, acabam gerando uma subutilização da mão de obra - então perguntar por que eles fazem daquele jeito, entender de que forma utilizam o corpo e encontrar com base na biomecânica a forma mais eficiente de trabalhar gastando menos calorias, evitando lesões, evitando fadiga. [...] basicamente começa com uma reunião inicial e depois com treinamento - tem que treinar até mesmo gestores; nós fazemos treinamentos para gestor, gerente, coordenador de produção, pessoal de recursos humanos, para orientá-los a distribuir as tarefas de forma balanceada. Caso contrário, você terá pessoas insatisfeitas - porque o trabalhador sabe que um está trabalhando mais e o outro menos.

A preocupação ergonômica interfere decisivamente no processo de decisão de compra de máquinas e equipamentos, o que vai além do custo financeiro. As decisões de compras desempenham um importante papel social dentro da organização - com a participação ativa dos colaboradores.

[...] a responsabilidade pela aquisição das máquinas, o orçamento e a gestão das compras é feita pela engenharia; existe um fluxo bastante complexo onde $100 \%$ das áreas opinam de acordo com a necessidade de cada área. [...] existem os checklists para aquisição de novas máquinas e equipamentos, e todas as áreas dão opinião. Cada área tem o seu checklist para atender suas necessidades: área da qualidade para atender a qualidade, área de segurança do trabalho para atender as normas de segurança do trabalho... A área de ergonomia tem um checklist de ergonomia, se alguma coisa foge do entendimento ou a resposta for negativa ao checklist - de 
segurança, de ergonomia... Não pode ter nenhum, não. [...] Ah, tem! Então já barrou a compra do equipamento.

Como medidas de resultados, o ergonomista considera o número de afastamentos pelo INSS por motivos ortopédicos (zerado na organização estudada) e a taxa de absenteísmo, observando-se os atestados médicos. No final, o principal indicador é a eficiência da linha.

[...] o resultado da ergonomia tem uma parte que é bem rápida, que é a parte aonde você consegue melhorar a produtividade - essa você consegue mensurar bem rápido. Já na parte do comportamento há mais resistência, porque para mudar comportamento você tem que mudar a cultura da pessoa. [...] Por isso que eu estou falando: a primeira etapa é treinar para ele entender que tem que ter revezamento. O gestor não fazia revezamento porque para ele tanto faz - se ele tem um funcionário que é bom colocando o frasco aqui, não tem por que mudar. [...] Trabalho pesado no sentido de postura, desgaste, ruim... Então na hora que implanta o revezamento, todo mundo enxerga aquele trabalho pesado. Um exemplo é a acuidade visual: nesse caso os colaboradores pediram se podiam fazer um revezamento num tempo menor, e hoje nós fazemos revezamento em alguns lugares a cada meia hora; do contrário, seriam oito horas por dia durante anos olhando uma lente de aumento.

Os resultados são medidos pelos incidentes na linha de produção e até mesmo pelos indicadores de treinamento.

[...] existe um fator de produção chamado de OEE, sigla em inglês que significa quanto tempo efetivamente a linha funcionou; aquela máquina ficou funcionando num turno de trabalho de oito horas. [...] Então você prova melhorando a eficiência das linha: quanto mais tempo a linha estiver funcionando, melhor - se ela estiver mais organizada, se as pessoas estiverem fazendo revezamento e todas tiverem capacitadas para fazer todas as tarefas, se ela não está gerando fadiga no trabalhador... [...] O colaborador é 
monitorado pelo médico do trabalho por um período. Se não tem nada feito de ergonomia ainda, o médico do trabalho comunica à área de ergonomia e solicita uma avaliação do posto de trabalho, da atividade ou alguma coisa diferente que esteja acontecendo lá.

Buscamos identificar os investimentos realizados pela empresa em ações ergonômicas - a forma como a ergonomia é vista e seus benefícios para a organização.

[...] propor adaptação nas condições de trabalho, às vezes automatizando uma parte do trabalho, às vezes mudando a organização do trabalho de maneira que parte do trabalho que seria difícil para ele fazer venha feito de outro lugar. [...] Um dos princípios de ergonomia - existem vários - é você trabalhar economizando energia física, o que significa, teoricamente, um número mágico de 1.800 calorias que um trabalhador pode gastar durante o dia; em alguns casos até 2.500 calorias está aceitável, fisiologicamente. Isso é fisiologia do trabalho. Se eu coloco um trabalhador para trabalhar em uma atividade e ele gasta 3.000 calorias, ele vai sair fadigado, no final do dia vai estar cansad... Mas se eu consigo proporcionar situações de trabalho em que as máquinas façam as atividades, ou aonde eu faça revezamento, consiga dosar a carga de trabalho do trabalhador, e no final do dia ele gaste 1.500 calorias, ele vai sair com bastante energia no final do dia. Isso é o tal do conforto: se eu gastei 1.500 calorias e produzi tudo, está ótimo.

Durante a implantação de processos, identifica-se uma preocupação em ouvir o trabalhador: não apenas em aumento de produtividade, mas entender o que de alguma maneira proporciona bem-estar.

[...] gestão das pessoas, isso demora um pouco mais. Um exemplo disso é o revezamento em linhas de produção: o primeiro trabalho que eu fiz foi entrevista com os trabalhadores, e é preciso saber o que ele pensa do trabalho dele, qual dificuldade ele tem para fazer o trabalho... Faço uma entrevista com número grande de pessoas, 
de áreas diferentes, identifico o que se repete de queixas... Isso passa a ser prioridade de plano de ação, caso contrário estará fazendo alguma coisa que não vai ser muito eficiente. Foi a primeira oportunidade que eu tive de proporcionar conforto interno: orientei fazer revezamento entre as tarefas. Agora, imagine a resistência de fazer o revezamento com um funcionário que há muito tempo faz uma tarefa leve, de ter que revezar com os colegas que fazem a tarefa pesada. [...] Tem funcionário que durante a entrevista diz que estava torcendo para conseguir outro emprego porque achava que fisicamente não ia aguentar ficar naquela função por muito tempo.

Os retornos financeiros para organizações que adotam medidas ergonômicas visando melhorias na qualidade de vida dos trabalhadores é facilmente percebido por elas. Assim, é possível avaliar como os gestores e colaboradores percebem os retornos desses investimentos.

[...] a empresa precisa de uma pessoa 100\% fisicamente ativa, só que eu vou fazer o seguinte: vou te dar duas pessoas, uma que consegue fazer metade do trabalho e outra que consegue fazer a outra metade. Para a engenharia isso é um prejuízo, porque você está colocando o custo duas vezes numa situação que ele teria um custo de um funcionário. Do ponto de vista de produtividade isso não é bom; se a empresa pensar em produtividade, o objetivo das indústrias é lucro, o objetivo das engenharias de produção é enxugar custos.

Durante a implantação dos processos de ergonomia, é possível perceber que ocorre redução da rotatividade de funcionários.

[...] supondo possivelmente trabalhos mais ruins, ruins são: mais difícil para fazer, mais pesado, mais rápido... Por isso tinha uma rotatividade grande de pessoas, ou seja: o funcionário ficava ali, mas ele não parava, ou ele saia e ia embora para outra empresa, ou faltava constantemente. 
A insatisfação e a fadiga podem acarretar em danos a todo o grupo de trabalho, bem como à produção.

[...] O que acontece se você gera uma fadiga no trabalhador, se ele fica cansado? Ele pensa: "assim eu vou ferrar a empresa". Ele vai ao banheiro para dormir, ele não está querendo saber se alguém vai fazer o trabalho dele ou não... O trabalhador encontra a pausa dele, o máximo que vai acontecer é "um dia vão me pegar e vão me mandar embora, se me mandarem embora eu vou receber $40 \%$ de FGTS" - então o trabalhador pensa assim, pensa deste jeito. [...] O trabalhador arruma um jeito de fazer a pausa dele, e aí, quando ele faz a pausa que não está no processo, você vai reduzir a produtividade da linha toda - porque um foi para o banheiro e não volta mais... Vai diminuindo a eficiência. Vai chegar uma hora que vai faltar material; cada vez que a máquina para por falta de material tem que reiniciar a máquina, e cada reinício de máquina perde alguns minutos... Somando vários reinícios no turno é que você faz a produtividade cair.

Observou-se que, talvez até pelo fato de o ergonomista ser educador físico e fisioterapeuta, existe um cuidado e uma preocupação com o bem-estar físico do trabalhador. No Brasil, porém, existe a necessidade de cumprimento da Norma Regulamentadora (NR) 17 que trata dos aspectos ergonômicos que devem ser adotados pelas organizações (BRASIL, 1978) e que visa, justamente, evitar o desgaste físico, os riscos de acidentes e lesões no trabalhador. Durante a entrevista, percebemos que existe sim uma preocupação com o aumento de produtividade - mas ficou claro que a preocupação maior é com a qualidade de vida do trabalhador, pois a empresa já entendeu que os arranjos ergonômicos proporcionam conforto, reduzem a fadiga e reduzem o desgaste físico desnecessário e, como consequência, geram melhor desempenho por parte dos trabalhadores.

[...] Você não tem nenhuma distinção na NR 17 com relação à idade, peso e altura. Está escrito lá uma observação no rodapé, mas no item da carga está dizendo: a carga máxima é aquela que não causa lesão. 
Após o ergonomista ter comentado que a empresa costuma avaliar o antes e o depois das ações ergonômicas, foi questionado se a preocupação era com o aumento de produtividade.

[...] sim, do equipamento, e de redução do risco. [...] o que a gente ganhou com isso! O que importa é não ter mais o risco, entendeu? É isso que eles pedem. Tecnicamente o gestor disse que existia um risco e resolveu o problema. [...] A palavra risco não precisa ter classificação - está com muito risco, pouco... Risco é risco, né. Uma boa parte das recomendações acabam mantendo o posto de trabalho num risco moderado porque tem uma das variáveis que classificam o risco ergonômico, que é a frequência que a pessoa faz o movimento, que é a repetitividade... Toda linha de produção tem trabalho repetitivo, então mesmo que tenha uma melhoria, olha: "você recomendou, a gente implantou, reduziu o risco, passou de moderado para baixo..." - não, ainda continua sendo moderado. Você tem faixas no moderado que você consegue ir reduzindo, mas que você não consegue zerar; então sempre que implantamos alguma coisa, continuamos implantando melhorias.

Durante a entrevista ficou notória a preocupação do ergonomista com a qualidade de vida dos funcionários, com a redução da fadiga e do desgaste físico e com a possível desmotivação pelo trabalho. Ações simples como o revezamento nos postos de trabalho podem contribuir tornando o ambiente de trabalho mais humanizado, melhorando o desempenho e o clima organizacional.

"[...] se eu coloco um trabalhador em uma atividade e ele no final do dia vai estar cansado, mas se eu consigo proporcionar situações de trabalho aonde as maquinas façam as atividades, aonde eu faça revezamento, e no final do dia ele saia com bastante energia, ele vai sair confortavelmente e produziu tudo que eu tinha que produzir - aí nós associamos conforto e produtividade. [...] basicamente é olhar as pessoas trabalhando, entender como elas fazem as atividades e encontrar a forma mais 
eficiente de trabalhar gastando menos calorias, evitando lesões, evitando fadiga. [...] Se você não mapear a carga de trabalho individual, você vai ter uma coisa desbalanceada e possivelmente pessoas insatisfeitas - porque o trabalhador sabe que um está trabalhando mais e o outro menos. O ergonomista tem que ouvir o trabalhador; não tem outro jeito de trabalhar como ergonomia se não for ouvindo o trabalhador. [...] a primeira etapa é treinar o funcionário para ele entender que tem que ter revezamento, tem gente que tem 5, 6, 7, 8 anos de empresa - ele está viciado e possivelmente com o tempo ele foi escolhendo aquela atividade que é mais fácil de fazer e tem menos esforço físico. Depois que você implanta a cultura do revezamento, o trabalhador não fica especialista só em uma atividade: ele conhece todas, e a empresa vai treinar ele em todas as atividades da linha."

O entrevistado explicou também que, no mundo inteiro, não há uma única formação acadêmica que é detentora da ergonomia. Na França, uma boa parte dos ergonomistas são psicólogos; nos Estados Unidos é mais comum serem da engenharia; no Brasil, a grande maioria é da área de saúde, como médicos, enfermeiros, psicólogos, educadores físicos, fisioterapeutas e terapeutas ocupacionais. No Brasil, a ergonomia se desenvolveu devido às doenças ocupacionais especialmente na década de 1990, quando cerca de 30\% dos bancários tinham Lesão por Esforço Repetitivo (LER).

\section{Levantamento com os empregados}

Foram ao todo 31 perguntas em escala Likert, na qual o funcionário deveria atribuir nota de 1 a 5 , sendo que a nota 1 significa "discorda totalmente" e a nota 5, "concorda totalmente".

Observou-se que pouco mais de $70 \%$ dos funcionários são do setor fabril; $22.4 \%$ das respostas vieram dos funcionários de escritório que trabalham com outros tipos de pressão e situações diferentes, e 3,5\% de funcionários de outros setores, não identificados. 
Com relação ao tempo de casa dos respondentes, 41,4\% estão na empresa há mais de cinco anos, 32,8\% estão há mais de um ano e 25,9\% são funcionários novos que tiveram interesse em participar da pesquisa e expor seu ponto de vista.

As perguntas visavam confirmar as informações fornecidas pelo gestor com relação a cada um dos aspectos relacionados à ergonomia.

\section{Ergonomia física}

As questões 1, 4, 8 e 18 visavam estabelecer o grau de satisfação com as condições de trabalho relacionado às características da anatomia humana, fisiologia e biomecânica - estas em sua relação com a atividade física. De maneira geral, a grande maioria dos funcionários demonstram-se satisfeitos com as condições de trabalho. Apenas 17\% dos respondentes ficaram entre os indecisos, fator este que pode ser atribuído aos funcionários mais novos conforme observado nas respostas individuais.

As questões 10, 13 e 29 trataram de tópicos relevantes que incluem o estudo da postura no trabalho, o manuseio de materiais, os movimentos repetitivos e os distúrbios musculoesqueléticos relacionados ao trabalho. A grande maioria dos funcionários confirmou as informações passadas pelo gestor: que existe uma preocupação e um cuidado para evitar tais desgastes físicos e danos à saúde do trabalhador.

Com relação ao projeto de posto de trabalho, segurança e saúde, as questões 20, 22, 26 e 31 contribuíram para nossa compreensão de que os esforços do ergonomista têm surtido efeitos positivos. Os projetos de produção são dimensionados de acordo com a quantidade de funcionários disponíveis para execução das tarefas e existem pouquíssimos casos de afastamento por motivos de saúde, além de uma redução expressiva com acidentes de trabalho - chegando a mais de 95\% de respostas que confirmam não haver acidentes, o que torna o trabalho do ergonomista bastante eficiente.

\section{Ergonomia cognitiva}

As questões 2, 5, 14, 19 e 30 referem-se aos processos mentais - tais como percepção, memória, raciocínio e resposta motora - e, como se pode observar de acordo com as respostas à pesquisa, a maior parte 
dos funcionários demonstra que existe uma boa relação nas interações entre seres humanos e outros elementos de um sistema.

Já as questões 7, 11, 16, 24 e 27 visam compreender os tópicos relevantes do estudo da carga mental de trabalho, de tomada de decisão, do desempenho especializado, da interação homem-computador, do estresse e de treinamento - conforme esses se relacionem a projetos envolvendo seres humanos e sistemas. De acordo com as respostas, mais de $70 \%$ dos funcionários demonstraram haver uma boa relação entre pessoas e máquinas, confirmando que os checklists proporcionam uma integração de todos os funcionários nos processos e que os equipamentos são adquiridos de forma a proporcionar bem-estar a todos os usuários.

\section{Ergonomia organizacional}

A otimização dos sistemas, incluindo suas estruturas organizacionais, políticas e de processos, são abordadas nas questões 6, 17, 25 e 28, e demonstraram haver um bom gerenciamento de recursos e de organização temporal do trabalho.

Com relação ao trabalho em grupo, ao projeto participativo, aos novos paradigmas do trabalho e ao trabalho cooperativo, as questões 3, 21 e 23 nos ajudam a confirmar que existe todo um conjunto de atividades do ergonomista que contribuem com o sucesso da organização; enquanto as questões 9, 12 e 15 reforçam a cultura organizacional, bem como a preocupação constante com a gestão da qualidade dos programas ergonômicos implantados e o grau de satisfação da grande maioria dos funcionários.

\section{Considerações finais}

As empresas são constituídas na sua grande maioria com o intuito de obter resultados financeiros e assim crescer - e não poderia ser diferente, pois assim geram mais empregos e contribuem economicamente com o desenvolvimento do país e da sociedade, melhorando as condições de vida das pessoas. Existem muitas maneiras de aumentar os lucros: aumentando a produtividade, reduzindo os custos de produção, reduzindo despesas etc. Mas o que se pôde observar é que, fazendo 
investimentos financeiros para implantação de ações ergonômicas, também é possível melhorar o desempenho de uma organização; o que aparentemente seria uma despesa a mais, na realidade pode se tornar um melhor resultado financeiro com uma melhor imagem perante a sociedade, e ainda ganhar o reconhecimento dos empregados e melhor desempenho destes - como é o caso deste estudo de caso.

Podemos dizer que a ergonomia tem contribuído fortemente para o sucesso desta organização. Durante a entrevista com o gestor foi possível perceber o empenho e a preocupação com a qualidade de vida e a saúde dos colaboradores, e, após a entrevista com os funcionários, foi possível confirmar tudo que o gestor afirmou na entrevista - e também foi possível perceber um elevado grau de satisfação dos empregados em trabalhar em uma empresa que se preocupa com o seu trabaIho, buscando gerar condições que não lhes causem desgastes físicos, estresse, fadiga, e que se preocupe com eles não somente no momento em que estão trabalhando na empresa, mas também quando não mais estiverem lá, quando forem mais velhos e até mesmo quando já estiverem aposentados. Percebemos que essa cultura organizacional se irradia de tal maneira entre os funcionários que contagia não apenas quem trabalha na empresa, mas também os seus parentes e amigos mais próximos; percebe-se, ao conversar com alguns colaboradores, um orgulho muito grande de participar da organização.

Uma organização com essas características atrai novos talentos com maior facilidade, reduz os índices de turnover, reduz o absenteísmo, aumenta a produtividade, melhora a qualidade de vida dos colaboradores e promove um envelhecimento saudável - desempenhando, assim, um papel social bastante relevante.

A dimensão individual observada foi o fato de a grande maioria dos funcionários não terem queixas com relação ao desgaste físico e as condições de trabalho encontradas na empresa. Também é notoriamente observado o alto índice de respostas que reforçam a satisfação em trabalhar na empresa, e o tempo de casa dos funcionários que gostam das atividades que exercem e não tem intenção nem de buscar novos empregos e nem mesmo de faltar.

A dimensão social é proporcionada pelo crescimento da empresa que a cada dia abre novos postos de trabalho e conta sempre com a 
participação dos funcionários nas decisões de compras de equipamentos e na preocupação com suas posições de trabalho e qualidade de vida.

Os retornos financeiros são observados pelo próprio crescimento da empresa, tanto no território nacional quanto em outros países. As novas aquisições (que tem se tornado frequentes), a posição e o reconhecimento mundial que a empresa ocupa e, juntamente, os próprios funcionários contribuem com maior empenho e produtividade e de forma alguma se sentem pressionados - fazem o trabalho com a maior naturalidade sem se sentirem cobrados ou forçados a produzir mais, graças ao clima organizacional e as políticas ergonômicas adotadas.

Comumente costumamos associar a ergonomia às condições de saúde ocupacional; é quase que de praxe que o profissional responsável seja da área de saúde - como nosso entrevistado observou, mundialmente são profissionais desta área que atuam com ergonomia ou, em alguns casos, são os engenheiros de produção. Porém, observamos no início da entrevista que neste caso específico ele foi contratado com o intuito inicial de reduzir o absenteísmo e supostas queixas dos supervisores de produção quanto às reclamações de funcionários sobre as condições de segurança e riscos de acidentes de trabalho.

O que torna relevante o tema deste trabalho, e que ficou notório durante o desenvolvimento deste estudo de caso, é que este tema é de vital importância para muitos profissionais de várias áreas bem como para administradores que poderão atingir mais facilmente seus objetivos, além de profissionais de gestão de pessoas que sempre buscam desenvolver ações que motivem mais os funcionários. Neste caso se pode observar o quanto ações ergonômicas bem estruturadas e com a participação de todos contribuíram para o sucesso e desempenho da organização.

\section{Referências}

ASSOCIAÇÃO BRASILEIRA DE ERGONOMIA. O que é ergonomia.

Disponível em: https://bit.ly/3IHTGw8. Acesso em: 10 mar. 2020. ABRAHÃO, Júlia; Sznelwar, Laerte Idal; Silvino, Alexandre; Sarmet, Maurício; Pinho, Diana. Introdução à ergonomia: da prática à teoria. São Paulo: Blucher, 2009. 
BRASIL. Ministério do Trabalho e Emprego. NR 17 - Ergonomia. Diário Oficial da União, Brasília, DF, 06 jul. 1978. Disponível em: https:// bit.ly/2Z53ITL. Acesso em: 13 out. 2018.

CEAD - CENTRO DE EDUCAÇÃO À DISTÂNCIA VIRTUAL. Ergonomia e qualidade de vida: bloco 01. Curitiba, 12 nov. 2015. Disponível em: https://bit.ly/34TTWSS. Acesso em: 20 jan. 2019.

CORTELLA, Mário Sergio. Por que fazemos o que fazemos? aflições vitais sobre o trabalho, carreira e realização. São Paulo: Planeta, 2016.

DELWING, Eduardo Becker. Análise das condições de trabalho em uma empresa do setor frigorifico a partir de um enfoque macroergonômico. 2007. Dissertação (Mestrado em Engenharia de Produção) - Escola de Engenharia, Universidade Federal do Rio Grande do Sul, Porto Alegre, 2007. Disponível em - https://bit. ly/34YZoE7. Acesso em: 26 jan. 2019.

IIDA, Itiro; GUIMARÃES, Lia Buarque de Macedo. Ergonomia: projeto e produção. São Paulo: Blucher, 2005.

LUCIO, Cristina do Carmo; Alves, Silvana Aparecida; Razza, Bruno Montanari; Silva, José Carlos Plácido da; Paschoarelli, Luis Carlos. Trajetória da ergonomia no Brasil: aspectos expressivos da aplicação em design. In: PASCHOARELLI, Luis Carlos; SILVA, José Carlos Plácido da (orgs.). A evolução histórica da ergonomia no mundo e seus pioneiros. São Paulo: Editora UNESP/Cultura Acadêmica, 2010.

MORAES, Anamaria. Quando a primeira sociedade de ergonomia faz 50 anos, a IEA chega aos 40, a Associação Brasileira de Ergonomia debuta com 16. In: CONGRESSO BRASILEIRO DE ERGONOMIA, 9., 1999, Salvador. Anais [...]. Salvador, 1999.

RAMAZZINI, Bernardino. As doenças dos trabalhadores. 3. ed. São Paulo: Fundacentro, 2000.

RIO, Rodrigo Pires do; PIRES, Licínia. Ergonomia: fundamentos da prática ergonômica. 3. ed. São Paulo: LTr, 2001.

SILVA, Andrea Aparecida. Abordagem ergonômica do ambiente de trabalho na percepção dos trabalhadores: estudo de caso em biblioteca universitária. 2007. TCC (Bacharel em Biblioteconomia) - Centro de Ciências Humanas da Educação, Universidade do Estado de Santa Catarina, Florianópolis, 2007. Disponível em: https://bit.ly/3511rHw. Acesso em: 12 jan. 2019 
SOUZA, João Paulo Campos de; RODRIGUES, Celso Luiz Pereira. Vantagens e limitações de duas ferramentas de análise e registro postural quanto à identificação de riscos ergonômicos. In: SIMPÓSIO DE ENGENHARIA DE PRODUÇÃO, 13., Bauru. Anais [...]. Bauru: Universidade Estadual Paulista, 2006.

SOUZA, Lilian Alves de. O homem e a qualidade de vida no trabalho. 2011. Monografia (Especialização em Gestão de Recursos Humanos) - Faculdade Integrada AVM, Universidade Cândido Mendes, Rio de Janeiro, 2011. Disponível em: https://bit.ly/3IQdDAT. Acesso em: 20 dec. 2018.

SOUZA, Renato José de. Ergonomia no projeto do trabalho em organizações: o enfoque macroergonômico. 1994. Dissertação (Mestrado em Engenharia de Produção) - Centro Tecnológico, Universidade Federal de Santa Catarina, Florianópolis, 1994.

SZNELWAR, Laerte Idal. Quando trabalhar é ser protagonista e o protagonismo no trabalho. São Paulo: Blucher, 2015. E-book.

VIDAL, Mario Cesar. Ergonomia na empresa: útil, prática e aplicada. Rio de Janeiro: Virtual Científica, 2002.

VIDAL, Mario Cesar. Guia para análise ergonômica do trabalho (AET) na empresa. Rio de Janeiro: Virtual Científica, 2003.

WISNER, Alain. A inteligência do trabalho: textos selecionados de ergonomia. São Paulo: Fundacentro, 1994.

YIN, Robert K. Estudo de caso: planejamento e métodos. 3. ed. Porto Alegre: Bookman, 2005. 



\title{
Qualidade de vida e gestão de carreira para estudantes de uma instituição de ensino superior de São Paulo - uma análise sobre as condições para o crescimento profissional
}

\author{
Breno Barbosa Lisboa \\ Dione Fagundes Nunes Gomes
}

\begin{abstract}
Resumo
O objetivo principal deste estudo consiste em entender sob quais circunstâncias os estudantes de Administração da instituição de ensino superior referida nesta pesquisa estão dispostos a ceder qualidade de vida para ocupar cargos de liderança. O estudo, de natureza qualitativa, valeu-se de entrevistas estruturadas cujo conteúdo utilizou a metodologia de análise de Bardin. Os resultados analisados mostram que as circunstâncias descritas pelos entrevistados podem ser consideradas como fatores de qualidade de vida que são importantes para eles na construção de suas carreiras, indicando assim que não pretendem sacrificá-los em prol da carreira porque são parte integrante da construção dela. Alguns desses fatores são: equilíbrio entre vida pessoal e profissional, flexibilidade de horário, trabalhar com um bom clima organizacional, fazer amizades no trabalho, ser reconhecido, aprendizado constante, entre outros.
\end{abstract}

Palavras-chave: Qualidade de Vida. Gestão de Carreira. Geração Z. Centenialls. 


\section{Introdução}

Este trabalho busca entender, principalmente, quais as condições que os estudantes do curso de Administração de uma instituição de ensino superior da cidade de São Paulo estão levando em consideração para atingirem cargos de liderança e se essa decisão está relacionada aos estudos feitos por eles(as) no ambiente de ensino.

O problema que envolve esse questionamento está no fato de que o tema qualidade de vida, tanto na instância pessoal quanto profissional, tem se tornado cada vez mais presente (principalmente após os anos 1980) em ambientes empresariais e acadêmicos. Essa maior presença do tema em debates cotidianos pode influenciar as condições que serão consideradas pelos(as) alunos(as) ao procurarem atingir cargos de liderança, pois tem como objetivo introduzir o tema na vida dos estudantes; além disso, é sabido que para tornar-se um(a) líder, é preciso ceder a certos prazeres e benefícios que proporcionam uma melhor qualidade de vida. Consequentemente, surgem as seguintes dúvidas: atualmente, os(as) alunos(as) de Administração dessa academia de ensino, sabendo desse cenário organizacional, estão dispostos(as) a desenvolver suas carreiras profissionais sob quais circunstâncias? Quais desses(as) almejam atingir cargos de liderança? De acordo com quais condições?

Gestão de carreiras é um tema amplo e que possui diversas formas de abordagem. Uma delas é de que o desenvolvimento de uma carreira é formado por níveis, como uma escada, em que cada degrau seria um cargo novo. O que sustenta cada degrau dessa escada são as responsabilidades que cada cargo exige; em uma comparação rápida, quanto maior o degrau, maior as responsabilidades (DUTRA, 2017).

Ao adquirir novas responsabilidades em uma empresa, são criadas também novas expectativas sobre a pessoa que as assumiu, o que torna seu trabalho mais estressante pelo aumento da pressão. Além disso, cabe a essa pessoa saber combinar seus conhecimentos técnicos com sua experiência a fim de encontrar soluções para problemas complexos.

A complexidade, segundo Dutra (2017), está ligada aos riscos em que uma atividade está envolvida. Uma atividade complexa, além de ser difícil para aqueles que não possuem o conhecimento técnico correto sobre ela, pode resultar em vários caminhos inesperados. Por isso, quando uma 
pessoa assume um cargo de liderança, ela precisa entender a complexidade de sua função através de seu conhecimento técnico e experiência, pois as decisões dela apresentarão consequências, esperadas ou não.

Esses fatos remetem ao questionamento principal deste estudo, que é: em que medida estudantes interessados em ascender a postos de liderança estão dispostos a sacrificar qualidade de vida?

Este trabalho tem como objetivo final entender sob quais circunstâncias os estudantes de Administração da instituição de ensino superior referida estão dispostos a ceder qualidade de vida para ocupar cargos de liderança. Para auxiliar no entendimento, outras ações se fazem necessárias, a saber: conceituar qualidade de vida, destacando suas implicações no universo do trabalho e investigar se (e até que ponto) os estudos realizados acerca do tema pelos(as) alunos(as) em questão influenciam a decisão dos estudantes em desenvolver suas carreiras.

Desde a década de 1970 (no Brasil, mais precisamente, após a década de 1990), os estudos acadêmicos sobre a administração de carreiras são cada vez mais recorrentes (DUTRA, 2017). De acordo com Dutra (2017 p. 3), esse "movimento" surgiu pela evolução de, basicamente, três aspectos: "[...] o aumento da complexidade técnica das organizações, a expansão dos mercados e o maior estímulo às pessoas para refletirem sobre seu modo de vida". De fato, nota-se que a administração da carreira não está mais apenas no controle das empresas; essa mudança no contexto (e de paradigma, que vem ocorrendo gradualmente) criou um processo de descentralização sobre essa função das organizações, abrindo espaço para uma maior liberdade no desenvolvimento da carreira dos empregados.

Por conta disso, a instituição de ensino superior utilizada neste trabalho, em seu curso de Administração, vem incluindo essa mudança de paradigma em diversas disciplinas (principalmente naquelas sobre gestão de pessoas). Esse debate acadêmico pode gerar questionamentos sobre a carreira profissional que os(as) alunos(as) pretendem construir, possibilitando o estabelecimento de condições e circunstâncias para o desenvolvimento dessa.

Portanto, o presente estudo mostra-se relevante para os estudantes dessa instituição de ensino superior e outras similares na medida em que busca analisar as circunstâncias que motivam esses(as) alunos(as) a desenvolver suas carreiras em um mundo cada vez mais dinâmico e competitivo. 
É igualmente pertinente para as organizações ao procurarem compreender melhor o posicionamento da chamada Geração Z em relação ao desenvolvimento de carreira e sua visão sobre o mundo do trabalho.

\section{Referencial teórico}

As organizações e a administração são fundamentais na história da humanidade. Porém, foi no século XVIII que houve uma ruptura importante na história administrativa: a Revolução Industrial. Segundo Maximiano (2012, p. 44), "[...] o desenvolvimento da administração foi influenciado pelo surgimento de uma nova personagem social: a empresa industrial". Uma das principais características desse período foi o trabalho especializado dos operários.

Esses trabalhadores sujeitavam-se a mais de doze horas de trabalho, sem possibilidade de contestar por melhores salários e condições mais humanas de trabalho; logo, o desenvolvimento da carreira era extremamente difícil. Até mesmo crianças chegavam a trabalhar naquelas fábricas (MAXIMIANO, 2012, p. 45). Por conta disso, surgem os sindicatos, com o intuito de proteger os trabalhadores dos abusos causados pelos donos do capital.

Do final do século XIX até os anos 1910, surgiu o movimento da Administração Científica, nos Estados Unidos (MAXIMIANO, 2012), que influencia até hoje a estrutura e os processos das organizações. Esse movimento surgiu com os estudos de Frederick Winslow Taylor (1856-1915), que tinham como objetivo, em suma, levar a produção fabril à eficiência máxima.

Dutra (2017) diz que a maneira como se procurava compreender as organizações, baseada nos princípios da Administração Científica, mostrava-se falha desde os anos 1980. Isso porque analisava as pessoas pelo seu cargo e suas funções em um ambiente cada vez mais dinâmico. Então, teve início (de maneira tímida) a análise por competência. O autor, especificando que essa é uma percepção advinda dos franceses, define que uma pessoa competente "[...] é aquela que contribui de alguma forma ao contexto que se insere" (DUTRA, 2017, p. 7). Além disso, explicita que, a fim de contribuir para o contexto, é fundamental 
que essa mesma pessoa compreenda a demanda do contexto sobre ela, para que não sejam apresentadas respostas incompletas e incorretas.

Porém, com o decorrer dos anos 1990, notou-se que essas demandas sofriam um processo vagaroso de intangibilidade, tornando a percepção sobre elas cada vez mais difícil (DUTRA, 2017). Esse processo alterou a maneira como as pessoas realizam seus trabalhos: "hoje, se uma pessoa simplesmente realizar seu trabalho e atingir suas metas, provavelmente, estará contribuindo pouco para a organização. Necessitamos de muito mais" (DUTRA, 2017, p. 7).

Então, percebendo uma realidade cada vez mais intangível e também que o conceito de competência não atendia mais à expectativa de analisar a carreira, a valorização, o desempenho, o desenvolvimento e a contribuição das pessoas com a organização, surge a ideia e a importância da complexidade, porque "ela se liga ao fato de a situação exigir níveis diferentes de articulação do repertório de determinada pessoa" (DUTRA, 2017, p. 10). "[V]erificamos que havia uma alta relação entre o nível de complexidade das atribuições e a responsabilidade das pessoas e seu nível de contribuição para o contexto" (DUTRA, 2017, p. 7). Ainda segundo o autor, a complexidade permite a mensuração da contribuição das pessoas.

Portanto, a evolução de uma carreira é muito mais baseada no nível de responsabilidades que as pessoas adquirem do que simplesmente ocupar uma função diferente. E esse estudo de gestão de carreira é relativamente novo no Brasil, possibilitando que mais pesquisas sejam realizadas acerca do tema.

A seguir, são abordados os temas: qualidade de vida, gestão de carreiras e Geração Z. As considerações geracionais se justificam por conta do público-alvo desta pesquisa, situado cronologicamente entre os Centenialls.

\section{Qualidade de vida}

Para iniciar as reflexões acerca da qualidade de vida, é interessante realizar a seguinte pergunta: "a qualidade de vida é, de fato, uma necessidade?". Para respondê-la, é preciso levantar algumas características da atual realidade: crescimento da expectativa de vida; expansão 
da consciência do direito à saúde; desenvolvimento da sustentabilidade; aceno a novos costumes e estilos comportamentais; mais tempo gasto no trabalho/atividades produtivas; e fortalecimento da responsabilidade social. E, como um "resumo" dessas particularidades, é mostrado que essas exigências são parte de uma natureza psicossocial (LIMONGI-FRANÇA, 2012).

Todas essas características afetam o bem-estar das pessoas, mas, a médio e longo prazo, são de difícil percepção. O que é mais perceptível a curto prazo é o estresse, que é a grande questão atual do mercado de trabalho e da sociedade em geral. Surgem novos meios de gestão, compostos pelo autocontrole, espaços virtuais, avanço tecnológico, comprometimento, questionamento da confiabilidade das organizações e outros aspectos (LIMONGI-FRANÇA, 2012).

Existem várias definições e visões sobre a Qualidade de Vida no Trabalho (OVT), porque ela envolve questões políticas, éticas e, principalmente, de necessidades pessoais. Vilas Boas e Morin (2015, p. 121) definem QVT como "[...] um conceito complexo, que combina dois aspectos principais: os fatores (determinantes da QVT) e os indicadores (componentes de QVT)".

A QVT pode ser mensurada por indicadores que avaliem: alto comprometimento com a organização; bom equilíbrio de vida profissional com pessoal; alto bem-estar psicológico; sofrimento psicológico baixo. Além disso, também existem fatores de OVT, ou seja, que a desencadeiam. Alguns são: autonomia; reconhecimento; objetivos de trabalho bem definidos; bom relacionamento interpessoal (independentemente de cargo ocupado); estabilidade; carga de trabalho justa; entre outras (VILAS BOAS; MORIN, 2015).

Por conta disso, é necessário definir fatores padronizados para analisar o tema. Esses fatores são originados das demandas de qualidade de vida, que "[...] pressupõem necessidades a serem atendidas no sentido da preservação pessoal e da sobrevivência da espécie" (LIMONGIFRANÇA, 2012, p. 23).

Então, são apresentados alguns desencadeadores de QVT típicos, como: relacionamentos e composições da vida pessoal, que contempla família, momentos de lazer, busca de cuidados com a saúde, melhor alimentação, crescimento da expectativa de vida e outros; definições 
socioeconômicas, como desemprego, tecnologia, globalização, sofisticação dos meios de consumo, políticas governamentais e outros; objetivos empresariais, envolvendo competitividade, diminuição de custos, construção de uma imagem positiva da organização, busca pela eficiência do produto/serviço etc.; pressões institucionais, como mudança de emprego, novas formas de poder, rapidez ao realizar atividades etc.

Em síntese, cabe uma definição de qualidade de vida que aborde o ser humano como um complexo biopsicossocial - em suma, toda pessoa tem necessidades fisiológicas, psicológicas e sociais - e procure conceituar o tema sob essa perspectiva. qualidade de vida é, portanto, "[...] a percepção do indivíduo sobre sua posição na vida, no contexto da cultura e do sistema de valores nos quais ele vive e em relação aos seus objetivos, expectativas, padrões e preocupações" (WHOOOL GROUP, 1994 apud LIMONGI-FRANÇA, 2012, p. 29).

\section{Gestão de carreira}

A base da Administração de Carreiras surgiu com a Escola de Administração Científica por conta da criação dos cargos ligados a postos de trabalho e do sistema de diferenciação entre eles. Como consequência dessa origem, a responsabilidade sobre a gestão de carreiras dos funcionários era das organizações, pois essas detinham um poder de decisão sobre os empregados (DUTRA, 2017).

Foi apenas nos anos 1960 que essa realidade mudou, consequência de três causas apontadas por Dutra: "[...] aumento da complexidade técnica das organizações, a expansão dos mercados e o maior estímulo às pessoas para refletirem sobre seu modo de vida" (DUTRA, 2017, p. 3), ou seja, a complexidade, a globalização e a maior importância com o bem-estar e a qualidade de vida.

Essa mudança ampliou os olhares de pesquisadores sobre o tema das carreiras, criando um amplo movimento de investigação na década de 1970. Com maior força nos Estados Unidos, essa "onda" de pesquisa chegou ao Brasil nos anos 1990. Isso mostra que Gestão de Carreiras ainda é um tema "novo" em nosso país e que precisa de mais estudos (DUTRA, 2017). 
Existem várias visões sobre o significado de carreira, mas essa não deve ser colocada como responsabilidade exclusiva das pessoas, sendo necessária a inclusão do ambiente social e da organização (empresa). Aliás, essa influência de pensar que a missão de construir a carreira é apenas da pessoa é originada de ideias da escola americana de psicologia e sociologia, o que mostra a força da influência dos Estados Unidos no Brasil e no mundo (DUTRA, 2017).

Como exemplo, têm-se a ideia de carreira proteana, desenvolvida por Hall (1996 apud SILVA et al., 2019), que refere-se a um acordo entre líderes e empregados, visando tornar o desenvolvimento da carreira responsabilidade do funcionário e não da empresa (SILVA et al., 2019).

London e Stumpf afirmam que

Carreira são as sequências de posições ocupadas e de trabalhos realizados durante a vida de uma pessoa. A carreira envolve uma série de estágios e a ocorrência de transições que refletem necessidades, motivos e aspirações individuais e expectativas e imposições da organização e da sociedade. $\mathrm{Na}$ perspectiva do indivíduo, engloba o entendimento e avaliação de sua experiência profissional, enquanto, na perspectiva da organização, engloba políticas, procedimentos e decisões ligadas a espaços ocupacionais, níveis organizacionais, compensação e movimento de pessoas. Estas perspectivas são conciliadas pela carreira dentro de um contexto de constante ajuste, desenvolvimento e mudança. (LONDON; STUMPF, 1982 apud DUTRA, 2017, p. 4)

Já Dutra elenca três aspectos que compõe, para ele, uma definição completa de carreira: "[...] uma série de estágios e transições que variam em função das pressões sobre o indivíduo originadas dele próprio e do ambiente onde ele está inserido" (2017, p. 4); uma perspectiva tanto do indivíduo quanto da organização, como consequência de uma relação entre esses; e um fruto da conciliação das expectativas do indivíduo e da organização (DUTRA, 2017).

Faz-se necessária a compreensão de certos conceitos sobre desenvolvimento de carreira. O primeiro é o da competência, 
surgido após a necessidade de mudança sobre as ferramentas de análise de carreira - antes, essas eram baseadas em abordagens da Administração Científica e fundamentavam sua análise nos cargos e funções das pessoas (o que não fazia mais sentido em uma realidade cada vez mais dinâmica).

O conceito de competência, mais fiel ao ponto de vista dos franceses, descreve que uma pessoa competente é aquela que colabora de qualquer maneira no contexto em que está envolvida. Mas, a fim de tornar-se uma pessoa competente, é necessário ter uma compreensão bem definida da demanda que está à sua volta, o que vai além de simplesmente ter conhecimento sobre determinado assunto e ter vontade de contribuir. Portanto, pode-se afirmar que a competência não dá conta de uma análise sobre carreira porque as demandas que recaem sobre as pessoas estão cada vez mais intangíveis (DUTRA, 2017).

Por conta disso, Dutra (2017) indica que foi necessário buscar um novo conceito que englobasse essa volatilidade das demandas; então, o conceito de complexidade ganhou as atenções. Através desse conceito, foi possível perceber que há uma forte correlação "[...] entre o nível de complexidade das atribuições e a responsabilidade das pessoas e seu nível de contribuição para o contexto" (DUTRA, 2017, p. 7). Consequentemente, é possível descrever duas definições operacionais: a de desenvolvimento, a qual aponta que esse ocorre quando uma pessoa assume responsabilidades e atribuições de maior complexidade; e de carreira, que é um segmento de degraus de complexidade (DUTRA, 2017).

Desse modo, pode-se pensar as pessoas como agentes transformadores, porque elas somam seus conhecimentos, habilidades e atitudes e os convertem em competência para a empresa (ou, simplesmente, agregam valor a ela). Essa conversão é realizada de diferentes maneiras, pois cada pessoa tem sua própria forma de combinar seus conhecimentos, habilidade e atitudes (DUTRA, 2017).

Por fim, é correto assumir que o aprendizado e o desenvolvimento dos indivíduos (e, consequentemente, de suas carreiras) se dá através de novos desafios e responsabilidades adquiridas, pois novos objetivos criam um sentimento de necessidade de aprender e agir (EVANS, 1996). 
Geração Z (Centenialls)

Pode-se definir a Geração Z (iGeneration ou Centennials) como os jovens que nasceram na era das tecnologias da informação e comunicação (conhecidas também por TIC) e da internet. Não há um consenso sobre o período que "inicia" essa geração; alguns pesquisadores consideram o ano de 1989, ou 1995, ou 1990 (e até o ano 2000), como "corte" para classificar a Geração Z. Dois fatores levantados para essa divisão em diversos nomes e datas são a (ainda) escassa pesquisa científica sobre o assunto e a recente elaboração do tema (BEZERRA et al., 2019).

Algumas características "padronizadas" pelos estudos e pesquisas presentes na literatura sobre o tema são:

- Maior facilidade no entendimento de novas e diversas informações;

- Dependência tecnológica;

- Utilização de um novo linguajar;

- Inquietude;

- Baixa tolerância com a dificuldade de outras pessoas no manuseio de ferramentas tecnológicas;

- Atingir rapidamente o sucesso na carreira, sem exercer demasiado esforço etc. (BEZERRA et al., 2019)

Porém, cabe analisar duas características específicas: "[...] flexibilidade no trabalho e a concentração dedicada a diferentes atividades no dia a dia" (BEZERRA et al., 2019, p. 137). As empresas precisam se adaptar a essas mudanças de características geracionais e, ainda, entender que a melhoria da expectativa de vida e o consequente aumento de tempo das pessoas no mercado de trabalho são desafios para as empresas.

Mesmo com pesquisas sendo realizadas sobre as características dos Centennials, é um erro admitir que todos os jovens pertencentes a essa geração possuem exatamente as mesmas personalidades; não é certo, pois cada pessoa sofre uma influência diferente dos ambientes sociais, culturais e regionais, "moldando" suas próprias características (BEZERRA et al., 2019).

Em meio a tantas possibilidades de distração, o celular e as redes sociais se configuram como um dos principais, e a Geração Z tende a estar mais "conectada", como já explicado. Consequentemente, as organizações necessitam de meios gerenciais motivacionais, atrativos e úteis para fazer 
com que seus ambientes corporativos retenham a atenção desses jovens. $\mathrm{E}$ diante de tantas organizações, de acordo com os olhares dos Centennials, mecanicistas e pouco criativas, os autores citam três novos "modelos" de carreira que se fortaleceram em meio a todo esse contexto: a "carreira sem fronteiras" (BEZERRA et al., 2019, p. 139), que gera uma "autonomia" decorrente da maior mobilidade entre empresas; a "carreira proteana", que assemelha-se à anterior; e a "carreira em ziguezague", que destaca o seguimento de mais de uma carreira em ascensão, ocorrendo ao mesmo tempo ou não (BEZERRA et al., 2019).

\section{Procedimentos metodológicos}

A pesquisa descritiva e de campo, segundo as proposições de Vergara (2016), utilizou roteiro de entrevista para a coleta de dados, submetidos então à análise qualitativa. Foram realizadas oito entrevistas com estudantes do curso de Administração da instituição de ensino superior considerada neste estudo, obedecendo os critérios de acesso e tipicidade (estudantes trabalhadores).

\section{Análise e interpretação dos dados}

O procedimento de análise dos dados coletados através das entrevistas é baseado na análise de conteúdo proposta por Bardin (2011 apud GOMES, 2016).

Segundo a autora, a análise de conteúdo "[...] aparece como um conjunto de técnicas de análise das comunicações que utiliza procedimentos sistemáticos e objetivos de descrição dos conteúdos das mensagens" (BARDIN, 2011 apud GOMES, 2016, p. 99). Sabendo disso, a técnica de análise de conteúdo escolhida para esta pesquisa foi a análise categorial.

A análise categorial é subdividida em quatro fases:

Pré-análise: 'fase de organização, período de intuições. Tem por objetivo tornar operacionais e sistematizar as ideias iniciais [...]'; Codificação: 'corresponde a uma transformação - efetuada 
segundo regras precisas - dos dados brutos do texto (por recorte, agregação e enumeração) que representa o conteúdo ou a sua expressão [...]; Categorização: 'é uma operação de classificação de elementos constitutivos de um conjunto por diferenciação e por reagrupamento (analogia) com os critérios estabelecidos [...]'; Inferência: 'a intenção da análise de conteúdo é a inferência (deduções lógicas) de conhecimentos relativos às condições de produção (ou recepção) que recorre a indicadores (quantitativos ou não)'. (BARDIN 2011 apud GOMES, 2016, p. 99)

\section{Pré-análise}

A primeira etapa da pré-análise consiste em escolher os documentos que serão analisados (GOMES, 2016). O documento de exame deste estudo é, portanto, o conteúdo das entrevistas realizadas.

A segunda etapa é a preparação do material (GOMES, 2016). A preparação feita para essa monografia foi a transcrição das respostas dos entrevistados durante a própria entrevista, sem utilizar o recurso de gravação.

A última etapa é a leitura flutuante das respostas transcritas das entrevistas (GOMES, 2016).

\section{Codificação}

O processo de codificação foi baseado nos dois objetivos específicos dessa monografia, que serviram como fundamento para a definição dos temas de análise.

Os temas de análise desse trabalho são, portanto, qualidade de vida e influência acadêmica. As Figuras 1 e 2 ilustram essa relação dos objetivos específicos com os temas de análise.

Objetivo Específico 1

Conceituar qualidade de vida, destacando suas implicações no universo do trabalho.

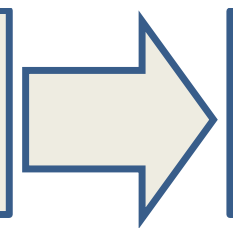

Tema de Análise

Qualidade de vida

Figura 1. Definição de tema de análise: qualidade de vida Fonte: Elaborado pelos autores (2019). 
Objetivo Específico 2

Investigar se, e até que ponto, os estudos realizados, acerca do tema qualidade de vida, pelos(as) alunos(as) da referida escola de ensino superior influenciam a decisão dos estudantes em desenvolver suas carreiras.

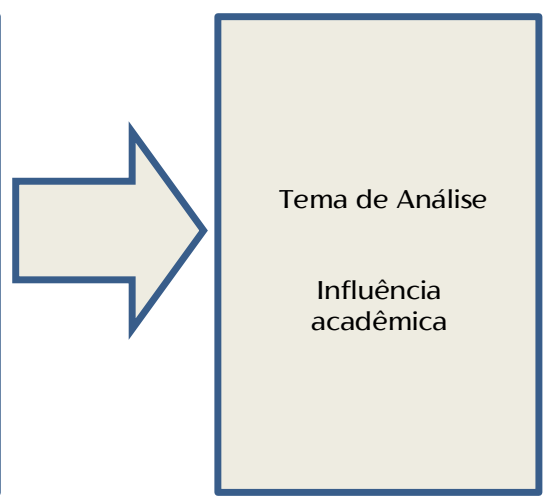

Figura 2. Definição de tema de análise: influência acadêmica Fonte: Elaborado pelos autores (2019).

\section{Categorização}

Baseando-se na orientação de Bardin (2011 apud GOMES, 2016), a categorização desta pesquisa segue o critério semântico (categorias temáticas), sabendo que os temas já estão indicados na estrutura da entrevista e na elaboração de suas questões.

A categorização selecionada foi a de "caixa", que se baseia em organizar por categorias e subcategorias os dados percebidos com a pesquisa. "As unidades de registro podem ser palavras, expressões ou frases sobre as quais se procede a inferência. Elas representam a menor parte do conteúdo que é necessário para alocar uma categoria" (GOMES, 2016, p. 103). E, por fim, são estabelecidas unidades de contexto para as unidades de registro, procurando exemplificar as unidades de registro com resultados que foram percebidos durante a aplicação da pesquisa.

Sabendo disso, todos os elementos da categorização citados acima são esquematizados em uma Matriz de Análise de Conteúdo, "[...] submetendo a composição de seus elementos ao conteúdo extraído das entrevistas e possibilitando a análise e interpretação dos dados, a partir das inferências produzidas" (GOMES, 2016, p. 104).

O Quadro 1 dispõe sobre as Matrizes de Análise de Conteúdo elaboradas para este trabalho. 
Quadro 1. Matriz de Análise de Conteúdo - Qualidade de Vida

\begin{tabular}{|c|c|c|c|c|}
\hline Tema & Categorias & Subcategorias & $\begin{array}{c}\text { Indicadores / } \\
\text { Unidades de } \\
\text { Registro }\end{array}$ & Unidades de Contexto \\
\hline \multirow{3}{*}{$\begin{array}{l}\frac{\pi}{0} \\
\frac{0}{0} \\
0 \\
0 \\
\frac{0}{0} \\
\frac{\pi}{0} \\
\frac{0}{2} \\
\frac{\pi}{07} \\
0\end{array}$} & \multirow{3}{*}{$\begin{array}{l}\text { Associação } \\
\text { de qualidade } \\
\text { de vida com } \\
\text { possíveis } \\
\text { elementos } \\
\text { constitutivos } \\
\text { de identidade } \\
\text { profissional }\end{array}$} & $\begin{array}{l}\text { Equilíbrio entre } \\
\text { vida pessoal e } \\
\text { profissional }\end{array}$ & $\begin{array}{l}\text { "Ter tempo", } \\
\text { "equilíbrio" }\end{array}$ & $\begin{array}{l}\text { "É ter equilíbrio } \\
\text { entre vida pessoal e } \\
\text { profissional, tendo } \\
\text { tempo para lazer e } \\
\text { cuidar da saúde..."; } \\
\text { "... sem deixar que o } \\
\text { trabalho ocupe todo } \\
\text { meu tempo disponível". }\end{array}$ \\
\hline & & $\begin{array}{l}\text { Realizar } \\
\text { desejos } \\
\text { pessoais }\end{array}$ & $\begin{array}{l}\text { "Viagens", "lazer", } \\
\text { "socializar" }\end{array}$ & $\begin{array}{l}\text { "Conseguir conciliar } \\
\text { a vida pessoal com a } \\
\text { profissional, atingindo } \\
\text { meus objetivos } \\
\text { (realizações) e ter um } \\
\text { bom convívio social". }\end{array}$ \\
\hline & & $\begin{array}{l}\text { Flexibilidade de } \\
\text { horário }\end{array}$ & $\begin{array}{l}\text { "Ter tempo", } \\
\text { "morar próximo } \\
\text { ao trabalho" }\end{array}$ & $\begin{array}{l}\text { "Ter Qualidade de Vida } \\
\text { é poder morar próximo } \\
\text { ao local de trabalho..."; } \\
\text { "Ter Qualidade de } \\
\text { Vida é poder ter } \\
\text { flexibilidade de horário } \\
\text { para trabalhar..." }\end{array}$ \\
\hline
\end{tabular}

Fonte: Elaborado pelos autores (2019).

Quadro 2. Matriz de Análise de Conteúdo - Influência Acadêmica

\begin{tabular}{|c|c|c|c|c|}
\hline Tema & Categorias & Subcategorias & $\begin{array}{c}\text { Indicadores / } \\
\text { Unidades de } \\
\text { Registro }\end{array}$ & Unidades de Contexto \\
\hline 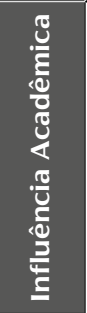 & $\begin{array}{l}\text { Associação } \\
\text { da influência } \\
\text { acadêmica } \\
\text { com possíveis } \\
\text { elementos } \\
\text { constitutivos } \\
\text { de identidade } \\
\text { profissional }\end{array}$ & $\begin{array}{l}\text { Mudança de } \\
\text { perspectiva } \\
\text { sobre QV após } \\
\text { o início do } \\
\text { curso }\end{array}$ & $\begin{array}{l}\text { "Ajudou", } \\
\text { "faculdade", } \\
\text { "não imaginava" }\end{array}$ & $\begin{array}{l}\text { "O dia a dia e a } \\
\text { faculdade me ajudam } \\
\text { a entender que não } \\
\text { quero isso (não ter QV) } \\
\text { para mim."; “... eu não } \\
\text { imaginava que ter } \\
\text { qualidade de vida era } \\
\text { tão importante". }\end{array}$ \\
\hline
\end{tabular}

continua na próxima página... 
Quadro 2. Continuação

\begin{tabular}{|c|l|l|l|l|}
\hline Tema & Categorias & Subcategorias & $\begin{array}{l}\text { Indicadores / } \\
\text { Unidades de } \\
\text { Registro }\end{array}$ & Unidades de Contexto \\
\hline$\frac{J}{3}$ & $\begin{array}{l}\text { Associação } \\
\text { da influência } \\
\text { acadêmica } \\
\text { com possíveis } \\
\text { elementos } \\
\text { constitutivos } \\
\text { de identidade } \\
\text { profissional }\end{array}$ & $\begin{array}{l}\text { Outros tipos } \\
\text { de influências } \\
\text { além da } \\
\text { acadêmica }\end{array}$ & $\begin{array}{l}\text { "Pai", "avô", } \\
\text { "Outras } \\
\text { experiências } \\
\text { profissionais", } \\
\text { "mercado", } \\
\text { "criação" }\end{array}$ & $\begin{array}{l}\text { "Sempre vi meu pai e } \\
\text { meu avô trabalhando } \\
\text { muito e não tendo tanta } \\
\text { qualidade de vida"; “... } \\
\text { porque do jeito que fui } \\
\text { criado e por falta de } \\
\text { experiência no mercado } \\
\text { de trabalho..." }\end{array}$ \\
\hline
\end{tabular}

Fonte: Elaborado pelos autores (2019).

\section{Inferências}

As inferências, que são análises baseadas nas Matrizes de Análise de Conteúdo realizadas, combinadas com os pressupostos teóricos presentes nesta pesquisa (BARDIN, 2011 apud GOMES, 2016), serão apresentadas a seguir no tópico Análise e interpretação dos dados, de acordo com cada tema definido na etapa Codificação.

Nesta seção, serão apresentadas considerações sobre os temas Qualidade de vida e Influência acadêmica, os quais fundamentaram a criação das duas Matrizes de Análise de Conteúdo apresentadas neste trabalho.

\section{Qualidade de vida}

Como mostrado no aporte teórico, a definição de qualidade de vida é subjetiva, variando de pessoa para pessoa. Tanto nas respostas obtidas com a aplicação do roteiro de entrevista quanto na consolidação de algumas dessas na Matriz de Análise de Conteúdo sobre qualidade de vida, é possível perceber que existe essa variação. Para exemplificar, seguem falas de entrevistados após a primeira pergunta da entrevista ("O que é qualidade de vida para você?"):

É ter equilíbrio entre vida pessoal e profissional, tendo tempo para lazer e cuidar da saúde. Além disso, poder ter boa mobilidade para ir ao trabalho também é importante. (E1) 
Alcançar meus objetivos de maneira equilibrada, com tempo para trabalhar, socializar e descansar. (E2)

Ter equilíbrio emocional e físico na maior parte do tempo. Além disso, ter tempo para descansar e me relacionar com outras pessoas, sem deixar que o trabalho ocupe todo o meu tempo disponível. (E6)

Ter qualidade de vida é poder ter flexibilidade de horário para trabalhar, podendo aproveitar a vida pessoal com viagens e com bons relacionamentos. Além disso, ter segurança e saúde também. (E7)

Porém, há certo padrão nas respostas, principalmente na subcategoria "equilíbrio entre vida pessoal e profissional". Apenas a oitava pessoa entrevistada (E8) não respondeu citando direta ou indiretamente essa subcategoria. Outros padrões também podem ser percebidos nas respostas à pergunta 7 (Liste três fatores de realização ligados ao trabalho que potencializam a sua qualidade de vida (em ordem de importância)): "Ter um bom clima organizacional" ou "ter um bom clima dentro da área" aparecem em três das oito respostas obtidas (37,50\% de frequência de resposta); "flexibilidade de horário" (que significa não ter horário para trabalhar definido) também apareceu em três respostas (37,50\% de frequência de resposta); "fazer amizades" ou "ter um bom relacionamento" surgiu, igualmente, em três respostas (37,50\% de frequência de resposta).

Esses padrões de resposta confirmam o que foi explicitado por Limongi-França (2012) ao dizer que esses fatores padronizados de qualidade de vida são originados das demandas de qualidade de vida, que "[...] pressupõem necessidades a serem atendidas no sentido da preservação pessoal e da sobrevivência da espécie" (LIMONGI-FRANÇA, 2012, p. 23).

Pelas respostas obtidas, pode-se perceber que há uma relação com os resultados obtidos pela pesquisa do Serviço de Proteção ao Crédito (SPC Brasil) e pela Confederação Nacional de Dirigentes Lojistas (CNDL). Isso porque a afirmação

"[...] planejam investir na profissão certa, dedicando-se a aprender e aprimorar conhecimentos, encontrar prazer e realização sem perder a qualidade de vida, ao mesmo tempo em que buscam uma vida estável, 
segura e saudável" (SERVIÇO DE PROTEÇÃO AO CRÉDITO, 2019, p. 2) foi claramente presente em todas as respostas dos entrevistados, sendo que todos são nascidos dentro do período definido para fazerem parte da Geração Z.

Ao relacionar qualidade de vida com o trabalho dos estudantes entrevistados, na pergunta 3 (A empresa em que você atua ajuda ou atrapalha (em que medida) a sua qualidade de vida?), as respostas foram bem variadas:

Onde trabalho, a empresa preocupa-se com a qualidade de vida dos funcionários, principalmente na minha área. (E1)

Mais ou menos. Muitas vezes a relação é desgastada por conta do nível de estresse. (E2)

Atrapalha, mas depende do momento da demanda pelo meu trabalho. Quando a demanda é maior, acabo trabalhando mais do que devo; mas tenho liberdade quando a demanda é menor. (E3)

É 'neutro', mas mais para o lado positivo. O que me faz bem é que a empresa tem um propósito de ajudar as pessoas através do que vendemos e produzimos e vejo que é verdade. Isso me ajuda no dia a dia. (E4)

Depende, porque sou incentivada a me desenvolver pessoal e profissionalmente, mas às vezes a carga de trabalho é tão alta em certos momentos que acabo me desgastando mais do que gostaria. Apesar disso, gosto do que faço. (E5)

Acredito que tenho uma qualidade de vida, mas por uma relação com minha gestora, diretamente. O RH não se envolve diretamente. Mas o que posso destacar e que ajuda meu dia a dia é o bom clima geral na empresa. (E6)

Ajuda muito pois é uma empresa flexível e com bons benefícios. (E7) 
Ajuda, pois prezam pela qualidade de vida. (E8)

Apesar de alguns apresentarem uma resposta não tão positiva, foi percebido, pela entonação e descrição, que todos esses estudantes sentem-se bem por trabalhar nas empresas em que estão. $O$ que indica esse comportamento pode ser percebido pelas respostas dadas na quinta pergunta (Você tem interesse em atingir cargos de liderança nessa organização? Por quê?):

Tenho muito interesse por ter apoio dos meus gestores (E2).

Sim, porque daria uma boa visibilidade para minha carreira. Além disso, gosto muito da empresa. (E3)

Sim, por conta dos benefícios e reconhecimento. (E4)

Não tenho vontade de fazer carreira lá, mas, se atingir um cargo de coordenação, já ficarei feliz. (E6)

Sim, porque é um ambiente agradável, com uma boa cultura e um bom relacionamento entre as pessoas. (E7)

Sim, porque são funções bem valorizadas. (E8)

As respostas dos entrevistados E1 e E5 não negaram interesse em atingir cargos de liderança nas empresas em que atuam, mas também não apresentaram uma resposta totalmente positiva. Apesar disso, esses estudantes demostraram, em outras respostas, que estão felizes nas empresas em que trabalham. Veja as falas dos entrevistados E1 e E5:

Não sei ainda. (E1)

Sim e não. Eu gostaria de atingir pelo meu desenvolvimento pessoal e profissional; mas, por ser um cargo de confiança, não há 
limite para o horário de trabalho e a cultura lá é muito voltada para resultado; ou seja, a pressão é forte. (E5)

Portanto, pode-se perceber que as definições de qualidade de vida de cada entrevistado estão condizentes com as definições abordadas por Limongi-França (2012) e que seus fatores se encontram, em certa medida, padronizados como citado pela literatura abordada no início desta pesquisa (LIMONGI-FRANÇA, 2012; VILAS BOAS; MORIN, 2015).

\section{Influência acadêmica}

A nona pergunta feita para os entrevistados foi: "A instituição de ensino superior em que você estuda, no curso de Administração, procura transmitir a importância da qualidade de vida, tanto na vida pessoal quanto na vida profissional. Antes de iniciar o curso, você tinha noção da importância de se ter qualidade de vida no trabalho?". Seis de oito respostas responderam "não". Confira a seguir:

Não, mas a faculdade não é $100 \%$ responsável pela minha percepção sobre isso hoje. Claro, ela ajudou; mas muito da minha visão sobre o assunto vem de experiências práticas em um ambiente de trabalho. (E1)

Não. Sempre vi meu pai e meu avô trabalhando muito e não tendo tanta qualidade de vida. O dia a dia e a faculdade me ajudam a entender que não quero isso para mim. (E2)

Não, porque do jeito que fui criado e por falta de experiência no mercado de trabalho, eu não imaginava que ter qualidade de vida era tão importante. (E3)

Não. (E4)

Não. Sempre acreditei que qualidade de vida era proveniente de salário e do cargo que você ocupa. (E5) 
Sim, por conta das outras experiências profissionais que tive na adolescência e por ver como meu pai ficava doente às vezes por conta do estresse no trabalho. (E6)

Sim, mas não na medida em que tenho hoje. Meu pai sempre foi executivo, o que fazia-o ser ausente em alguns momentos. (E7)

Não, porque é preciso ter experiência no mercado para saber. (E8)

As respostas (com exceção da resposta dada pelo E6) indicam algum grau de influência sobre a percepção da importância da qualidade de vida advindo dos estudos realizados no curso de Administração da instituição de ensino superior referida. Para alguns, em maior medida; para outros, em menor medida. Isso mostra que essa instituição tem um papel importante, independentemente do grau, nas visões de seus estudantes acerca de suas vidas profissionais e pessoais.

Porém, é possível perceber outros tipos de influências na percepção desses estudantes: do relacionamento com parentes durante a infância/ criação e de experiências no mercado de trabalho.

A influência parental mostrou-se muito forte no depoimento dos entrevistados, mostrando a diferença entre as gerações. Alguns afirmam que não pretendem gastar tanto tempo de seus dias focados apenas no trabalho, como muitos parentes deles fazem/faziam. Essa percepção é sentida pelas empresas e obriga-as a mudar a maneira de tratar seus empregados.

E essa mudança, por parte das empresas, já está ocorrendo, como pode ser exemplificado pelas respostas obtidas na pergunta 3 (apresentadas na análise sobre o tema Qualidade de vida). Ela foi citada por Maximiano (2012) ao descrever o contexto histórico desde o Taylorismo até os dias atuais, e Dutra (2017), ao citar o conceito de complexidade (influenciado pela mudança no contexto e do ambiente de trabalho), também nos mostra essa reflexão. 


\section{Considerações Finais}

Baseado na justificativa que permitiu sua construção, o objetivo principal desta pesquisa era entender sob quais circunstâncias os estudantes de Administração da instituição de ensino superior referida neste estudo estão dispostos a ceder qualidade de vida para ocupar cargos de liderança. O objetivo foi alcançado a partir da análise dos conteúdos das entrevistas realizadas.

Já os objetivos específicos (conceituar Qualidade de Vida, destacando suas implicações no universo do trabalho e investigar se, e até que ponto, os estudos realizados acerca do tema pelos(as) alunos(as) em questão influenciam a decisão dos estudantes em desenvolver suas carreiras) foram alcançados pelo referencial teórico, mais as respostas dos entrevistados e os depoimentos acerca dos fatores de qualidade de vida que consideram relevantes.

Algumas circunstâncias descritas pelos entrevistados podem ser consideradas como fatores de qualidade de vida que são importantes para eles na construção de suas carreiras, indicando assim que não pretendem sacrificá-los em prol da carreira, mas sim que fazem parte da construção dela. Alguns desses fatores são: equilíbrio entre vida pessoal e profissional; flexibilidade de horário; trabalhar com um bom clima organizacional; fazer amizades no trabalho; ser reconhecido; e aprendizado constante.

A justificativa deste trabalho está fundamentada na ideia de que os ensinamentos e estudos realizados na referida instituição de ensino superior podem ocasionar em reflexões, por parte de seus estudantes, que posteriormente serão importantes para a decisão deles acerca da construção de suas carreiras profissionais, o que evidenciaria um peso muito grande da instituição na vida de seus(suas) alunos(as).

A instituição considerada no estudo apresenta essa característica influenciadora e que se firma, dentre muitos outros fatores, como um meio formador, e/ou sustentador, e/ou questionador de opinião, através dos estudos, pesquisa e percepções sobre o contexto. Isso evidencia ainda 
mais a importância da educação para qualquer pessoa ao possibilitar um fortalecimento do conhecimento dos indivíduos e torná-los mais críticos.

Além disso, este estudo permite uma reflexão sobre o contexto em que está inserido o mercado de trabalho. Os avanços tecnológicos, a globalização, a preocupação com a sustentabilidade (em todo seu significado: social, econômico e ambiental) e outros fatores estão possibilitando um crescimento acelerado do desenvolvimento humano $\mathrm{O}$ que permite muitos questionamentos, inclusive por parte daqueles que estão ingressando no mercado de trabalho brasileiro.

O alto desemprego, a preocupação com a saúde física e mental, a necessidade de consumir e diversos outros aspectos são terrenos férteis para o surgimento de muitas dúvidas entre os jovens brasileiros sobre seus futuros. Porém, essa nova geração (Centenialls) tem se mostrado cada vez mais disposta a lutar por seus direitos de ter uma vida com mais qualidade, principalmente após ter a possibilidade de estudar a situação das gerações anteriores.

$\mathrm{E}$, ao mesmo tempo em que essa geração mostra ser um tanto quanto desafiadora para aqueles que não a compreendem (inclusive para si mesma), a expectativa é de que ela busque aquilo que será o bem coletivo. Porque ela se vê em um contexto desafiador e complexo que a obriga a procurar uma maneira de entender e superar essa complexidade, podendo ocasionar soluções muito positivas para a sociedade.

Um exemplo disso é o próprio mercado de trabalho. É perceptível que as empresas estão procurando maneiras de tornar o ambiente de trabalho o melhor possível, para atrair esses jovens e para sua própria sobrevivência. Isso mostra um avanço muito poderoso, se analisarmos como era o ambiente de trabalho pouco mais de 35 ou 40 anos atrás. Diversidade, qualidade de vida, propósito de trabalho e trabalho em equipe são algumas das palavras "revolucionárias" desse contexto.

Portanto, apesar de um ambiente desafiador e complexo, há uma perspectiva positiva sobre o futuro, que precisará cada vez mais de novos estudos e pesquisas que auxiliem na análise de uma sociedade cada vez mais complexa, principalmente no Brasil, onde ainda são necessários muitos estudos em qualquer que seja o tema. 


\section{Bibliografia}

BEZERRA, Mariana Maia et al. GERAÇÃO Z: relações de uma geração hipertecnológica e o mundo do trabalho. Revista Gestão em Análise, Fortaleza, v. 8, n. 1, 2019. Disponível em: https://bit.ly/32DtkE0. Acesso em 17 jul. 2019.

DUTRA, Joel Souza. Gestão de Carreiras: a pessoa, a organização e as oportunidades. 2. ed. São Paulo: Atlas, 2017.

EVANS, Paul. Carreira, Sucesso e Qualidade de Vida. Revista de Administração de Empresas, São Paulo, v. 36, n. 3, p. 14-22, 1996. Disponível em: https://bit.ly/3hHx0sA. Acesso em: 30 jul. 2019.

GOMES, Dione Fagundes Nunes. Construção da identidade profissional em jovens universitários bolsistas: um estudo a partir dos valores e das definições de âncoras de carreira. 2016. Tese (Doutorado em Administração) - Pontifícia Universidade Católica de São Paulo, São Paulo, 2016.

LIMONGI-FRANÇA, Ana Cristina. Qualidade de Vida no Trabalho - QVT: conceitos e práticas nas empresas da sociedade pós industrial. 2. ed. São Paulo: Atlas, 2012.

MAXIMIANO, Antonio Cesar Amaru. Teoria geral da administração: da revolução urbana à revolução digital. 7. d. São Paulo: Atlas, 2012.

SILVA, Arthur Leonardo Imamura Ferreira da et al. A influência da Carreira Proteana em suas Respectivas Âncoras na Gestão de Carreira de Servidores Públicos. Journal of Accounting, Management and Governance, Brasília, v. 22, n. 1, 2019. Disponível em: https://bit.ly/ 3ccUqoD. Acesso em: 29 jul. 2019.

SERVIÇO DE PROTEÇÃO AO CRÉDITO. Salário alto não é garantia de sucesso profissional para os jovens da Geração Z, aponta pesquisa CNDL/ SPC Brasil. SPC Brasil, São Paulo, 22 jul. 2019. Disponível em: https://bit.ly/3kpHuyH. Acesso em 17 set. 2020.

VERGARA, Sylvia Constant. Projetos e relatórios de pesquisa em administração. 16. ed. São Paulo: Atlas, 2016.

VILAS BOAS, Ana Alice; MORIN, Estelle M. Stress no Trabalho, Bem-Estar Psicológico e Comprometimento com o Trabalho: Efeitos e Relações com a Qualidade de Vida no Trabalho. In: ROSSI, Ana Maria; MEURS, James A.; PERREWÉ, Pamela L. (Orgs.). Stress e Qualidade de Vida no Trabalho: stress interpessoal e ocupacional. São Paulo: Atlas, 2015. 



\title{
O papel da simplicidade no trabalho
}

\author{
Valéria Bullo Robalinho \\ Elisabete Adami Pereira dos Santos
}

\begin{abstract}
Resumo
O objetivo deste capítulo é apresentar os resultados principais da pesquisa para o Trabalho de Conclusão de Curso realizado no segundo semestre de 2019. O trabalho teve como objetivo discutir o papel da simplicidade no ambiente profissional, principalmente no mundo de hoje, com foco na simplicidade da comunicação (escrita, oral e visual) e do ambiente de trabalho, bem como demonstrar se essas estratégias e a adesão a práticas descomplicadas podem ser importantes na atualidade para garantir profissionais mais produtivos e contentes. Para o estudo, foi realizada uma entrevista com uma profissional da área com perguntas abertas e pesquisas de campo com questionários por escalonamento Likert. As questões foram aplicadas dentro do universo de estudantes da PUC-SP e gestores do Itaú Unibanco S.A., com uma amostra total de 40 pessoas, todas da cidade de São Paulo. Os dados foram coletados por meio de análise qualitativa e quantitativa, e seu resultado, combinado com os estudos feitos, mostrou que de fato a simplicidade tem grande importância no ambiente de trabalho hoje, podendo ser muito útil na gestão de times, na prevenção de impactos negativos trazidos pelo mundo VUCA e no melhor alcance dos objetivos. Dessa forma, pode ser praticada de forma organizada, inteligente, com atitudes simples e metodologias ágeis. Pessoas que são incentivadas a trabalhar em ambientes com conceitos mais simples performam melhor e são mais felizes, uma vez que não precisam gastar tempo com aquilo que não é importante.
\end{abstract}

Palavras-chave: Simplicidade. Leis da simplicidade. Aplicações da simplicidade. Modelos ágeis. Complexidade. Mundo VUCA. KISS. 


\section{Introdução}

Vivemos hoje em mundo cada vez mais complexo, tecnológico, acelerado, exigente e, muitas vezes, tóxico, com cada vez mais informações e distrações. Essa realidade do mundo moderno influencia na vida dos profissionais, podendo causar impactos negativos no equilíbrio emocional, problemas de saúde, ansiedade, apatia, falta de atenção e energia (ANDRADE, 2018).

Recebemos, processamos e repassamos uma série de informações durante o dia de trabalho. Muitas informações em relação a projetos, com uma série de entregas, objetivos, previsões, metas, cronogramas, orçamentos, aprovações. Muitas informações nas relações de trabalho, com hierarquias internas (sejam pares, gestores ou subordinados) e externas (com fornecedores, clientes, terceiros). Muitas informações em relação aos processos, com uma série de burocracias, controles, regras, fluxos, treinamentos, contatos. Muitas informações em relação ao ambiente de trabalho, desde o computador, com e-mails, pastas, documentos, redes, até cadernos, objetos de mesa, colegas de trabalho, barulhos, toques de telefone, conversas, reuniões. E como se não bastasse, além do ambiente de trabalho propriamente dito, ainda há muitas informações que vêm do celular, pessoal ou corporativo, com mensagens, ligações, notificações, aplicativos. Estamos conectados o tempo todo, física ou virtualmente, recebendo, processando e repassando informações, sejam elas relevantes ou não, verdadeiras ou não (ANDRADE, 2018).

Há profissionais que demonstram dificuldade em explicar, de forma simples e objetiva, o que fazem em seu trabalho, qual o objetivo de seu projeto, qual a função de seu cargo dentro da empresa. Alguns sentem-se inseguros ao perguntar ou repassar algo aos seus superiores, pois sabem que terão de explicar muita coisa em pouco tempo. Outros precisam fazer uma apresentação e sentem a necessidade de usar palavras sofisticadas para parecer mais competentes ou importantes, como uma forma de buscar valor naquilo que está sendo passado. Leva-se horas para finalizar uma reunião e, ao seu final, nem sempre todas as dúvidas foram sanadas ou todas as decisões tomadas. Horas para escrever um e-mail formalizando uma conversa. Horas para começar uma tarefa pelo 
simples fato de não se ter compreendido $100 \%$ qual o seu objetivo e aonde se quer chegar (ANDRADE, 2018).

Parece nítida a importância da simplicidade no ambiente profissional - local no qual se está durante o maior tempo do dia sendo cobrado por resultados, dedicando horas de trabalho em troca de salário - para que os funcionários trabalhem contentes, motivados e queiram ser produtivos. Atitudes simples parecem conquistar papel cada vez maior na vida e principalmente no meio profissional, seja ele qual for, para que situações rotineiras, como se comunicar com os outros de forma escrita, oral e visual, não seja algo complicado (ANDRADE, 2018).

Diante dessa realidade, algumas empresas têm valorizado formas mais simples para lidar com o funcionário por meio da comunicação e do próprio ambiente de trabalho. Muitos profissionais também têm trazido para suas empresas e incentivado modelos ágeis de gestão, com metodologias Scrum e design thinking, temas que serão apresentados no trabalho.

A simplicidade corresponde a tudo o que não é excesso e desperdício, é a essência das coisas e das pessoas. É o caminho contrário aos exageros do ego, é o que há de essencial. Na simplicidade não há exageros, mas sim o que se é, de maneira genuína e autêntica. (ANDRADE, 2018, p. 16)

A simplicidade é a ausência de complicação. É de fácil compreensão, sem excesso e desperdício. O conceito e as características da simplicidade, modelos e princípios para aplicá-la na prática e dores do profissional que podem ser atendidas por ela são temas também tratados ao longo do estudo. Nesse sentido, a qualidade de vida no trabalho é indispensável à produtividade e à competitividade, responsáveis pela sobrevivência das empresas. Para obter sucesso, Eda Fernandes (1996) afirma que as empresas precisam investir na satisfação dos trabalhadores em relação as suas condições de trabalho.

O trabalho de conclusão de curso que é fonte deste texto teve como origem um projeto de pesquisa, cujo problema apresentado foi: Quais os impactos da simplicidade na comunicação escrita, oral e visual, e no ambiente de trabalho para os funcionários? Essas estratégias 
poderiam ser cruciais na atualidade para garantir profissionais produtivos e contentes?

As hipóteses que respondiam ao problema apresentado eram:

1. A simplicidade no trabalho traz predominantemente impactos positivos, essenciais para o profissional.

2. A simplicidade no trabalho traz impactos positivos, porém variam de acordo com o perfil do profissional.

3. A simplicidade no trabalho é desejada, porém não facilmente alcançada pelos funcionários.

4. O gestor influencia sobremaneira o ambiente organizacional tanto na simplificação quanto na complicação.

Ainda relativamente ao projeto de pesquisa, seus objetivos eram: discutir o papel da simplicidade no trabalho, principalmente no mundo de hoje, com foco na simplicidade da comunicação (escrita, oral e visual) e do ambiente de trabalho; demonstrar como o incentivo dos gestores e sua adesão às práticas descomplicadas no dia a dia com seus times podem trazer um ambiente melhor, com funcionários satisfeitos e produtivos.

O estudo envolveu os aspectos da simplicidade no trabalho partindo do entendimento do conceito de simplicidade, principais modelos e princípios na qual ela é aplicada e seus impactos quando colocada em prática no ambiente corporativo brasileiro no contexto atual. O estudo aborda esses temas com foco na comunicação (escrita, oral e visual) e no ambiente (físico e emocional, que equivale ao clima organizacional) de trabalho, analisando os impactos da simplicidade e qual a importância dela para o funcionário, sendo ele gestor ou não.

Admitindo os aspectos do mundo no qual estamos inseridos hoje, complexo, acelerado e cheio de informações, e os impactos negativos que essas características podem trazer aos funcionários, entender o conceito de simplicidade, suas aplicações e resultados passa a ser essencial para perceber seu papel na garantia de funcionários mais contentes, motivados e produtivos. Esse conhecimento traz suporte ao funcionário, que anseia melhor performance e qualidade de vida no trabalho, e aos gestores, que querem garantir isso às suas equipes.

Subsidiariamente, o resultado do estudo poderá também contribuir para avaliar mudanças na cultura organizacional e possíveis alterações 
no modelo de gestão baseado no conceito, princípios e modelos aplicáveis de simplicidade; enriquecer a área de recursos humanos e fundamentar treinamentos de gestão de pessoas.

O primeiro item aborda o que é a simplicidade, seguido de sua conceituação. Em seguida, são apresentados os impactos da complexidade advindos do mundo corporativo brasileiro atual e os reflexos do mundo VUCA. A sequência demonstra os modelos usados na implementação da simplicidade como forma de atender às mudanças do mundo e do mercado em busca também de sanar alguns efeitos que essa realidade traz aos funcionários e às empresas: as metodologias ágeis e o modelo japonês de administração. Como forma de concretização da teoria, em seguida, são explicadas, passo a passo, as formas reais de aplicação da simplicidade no trabalho na prática. Logo após, é abordada a metodologia do estudo, definindo o tipo de estudo e a análise dos dados e, com isso, são apresentados os resultados e a consequente análise deles. Por fim, apresentam-se as considerações finais e as referências bibliográficas.

\section{Simplicidade}

\section{Conceito de simplicidade}

Simplicidade é a ausência de exageros, artifícios, extravagâncias, tanto na forma física e material como na retórica, na forma de se comunicar, escrever, apresentar, analisar ou resolver um problema. É aquilo que é simples, natural. Simplificar significa, portanto, descomplicar, se desfazer dos exageros, do desnecessário, buscando o fácil entendimento. É o oposto de complicado, e não de complexo (SIGNIFICADOS, 2016; ANDRADE, 2018). Para Andrade (2018), a simplicidade é aquilo que não tem excesso, exageros e desperdício, é o que há de essencial, de forma autêntica e genuína.

Diferentemente da simplicidade, o simplismo é caracterizado como uma tendência à simplificação, que considera apenas uma face ou aspecto das coisas, desprezando elementos fundamentais para o entendimento do todo. É possível entender o simplismo como uma simplificação exagerada, o que prejudica a compreensão (CARDOSO, 2018). 
Complicar é fácil, simplificar é difícil. Para alcançar o simples é necessário ter a capacidade de filtrar aquilo que realmente importa daquilo que não acrescenta valor, dedicando tempo e energia no que realmente for necessário. Esse processo demanda maturidade, conhecimento, coerência e sofisticação, e, com esse artifício, torna-se possível distinguir mensagens simples daquelas apenas simplistas, percebendo que soluções simples para um problema são boas soluções (SHINYASHIKI, 2017).

Algumas frases famosas de pessoas inspiradoras revelam bem a essência da simplicidade: "Simplicity is the ultimate sophistication", slogan da Apple em 1977 e frase também atribuída a Leonardo da Vinci; e "Que ninguém se engane, só consigo a simplicidade através de muito trabalho", de Clarice Lispector, em A Hora da Estrela (1977).

No contexto atual, conectado e apressado, é necessário aprender a lapidar os excessos desnecessários e até prejudiciais ao alcance dos objetivos. Assim, facilita-se o entendimento e clareia-se a mente para dedicar tempo e energia ao que é mais importante e significativo. Com o artifício da simplicidade, enxerga-se melhor aquilo que é mais importante (SHINYASHIKI, 2017).

Steve Jobs acreditava que o máximo do design estava enraizado na simplicidade. Picasso falou que ele levou uma vida inteira para aprender a pintar como uma criança. Jobs tinha uma atitude semelhante em relação à simplicidade de design, acreditando que esse processo era resultado de experimentações, testes, ajustes e melhorias meticulosas. Para ele, design complexo é resultado de fracassos fundamentais. Na resolução de problemas, Jobs afirma que os problemas têm camadas de complexidade e suas soluções inevitavelmente acabam se tornando complexas. Ultimamente o que devemos fazer é achar soluções que lidem com toda essa complexidade, mas de forma simples (SMITH, 2014).

A definição da simplicidade como o máximo de sofisticação é uma ideia oriental. Questionado sobre como conseguia fazer obras tão perfeitas com blocos de pedra tão imperfeitos, como a estátua de Davi, Michelangelo explicou que entendia a escultura como se estivesse aprisionada dentro do bloco, e que para libertá-la, bastava eliminar os excessos. Enxergava o trabalho do escultor como eliminador de

1 A simplicidade é o último grau de sofisticação - tradução da autora. 
excessos, entendendo que a beleza estava na falta de qualquer excesso, isso é, na absoluta simplicidade (DE MATTOS, 2009).

Na Era Industrial, a produtividade era medida pelo volume produzido. Mais era melhor. Criar mais, e mais complexo. No entanto, agora, na Era da Informação, a complexidade não tem mais valor. Criar mais não tem qualquer ligação com a produtividade. Mais e mais pessoas estão aprendendo que é preciso simplificar, e não complicar. (DE MATTOS, 2009, p. 37)

\section{Impactos da complexidade advindos do mundo cor- porativo atual - reflexos do mundo vuca}

Segundo o Ministério da Previdência Social, a concessão de auxílio-doença acidentário aumentou em quase vinte vezes nos últimos dez anos. A segunda maior causa de afastamento do trabalho são transtornos mentais e emocionais. Estimativas do Fórum Econômico Mundial alertam que os gastos relacionados a esses transtornos podem chegar a 6 trilhões de dólares até 2030 em todo o mundo - valor superior a todos os custos relacionados ao câncer, diabetes e doenças respiratórias somados. Essa previsão pode ser ainda maior considerando que dois terços das pessoas não procuram auxílio médico especializado. E mais: apesar de a Organização Mundial da Saúde (OMS) afirmar que uma em cada quatro pessoas sofrerá com um transtorno da mente ao longo da vida, são raros os casos de empresas que mantém algum programa de saúde psicológica ou emocional para seus colaboradores (SENDIN, 2016).

De acordo com a Isma-BR, representante da organização sem fins lucrativos International Stress Management Association no Brasil, nove em cada dez trabalhadores apresentam algum sintoma de ansiedade, do grau mais leve ao incapacitante, e metade (47\%) sofre de algum nível de depressão, recorrente em 14\% dos casos (SENDIN, 2016).

O excesso de trabalho é a principal causa de uma doença famosa chamada Síndrome de Burnout ou Síndrome do Esgotamento Profissional, caracterizada como um "distúrbio emocional com sintomas de exaustão extrema, estresse e esgotamento físico" causado por conta 
de situações de trabalho desgastantes, excessivamente competitivas ou que exigem alto grau de responsabilidade (MINISTÉRIO DA SAÚDE, 2019).

Comum em profissionais que atuam diariamente sob pressão, como médicos, enfermeiros, professores e policiais, a Síndrome de Burnout também pode surgir quando o funcionário não se acha apto a realizar determinadas tarefas por serem muito difíceis e não ter capacidades suficientes para cumpri-las. Já no surgimento dos primeiros sintomas é essencial buscar apoio profissional, pois um dos possíveis resultados dessa síndrome é um estado de depressão profunda. Alguns dos principais sintomas são nervosismo, sofrimentos psicológicos e problemas físicos, assim como o estresse e a falta de vontade de sair da cama ou de casa constantes (MINISTÉRIO DA SAÚDE, 2019).

Muitas pessoas não buscam ajuda médica por não saberem ou não conseguirem identificar todos os sintomas e, por muitas vezes, acabam negligenciando a situação sem saber que algo mais sério pode estar acontecendo. (MINISTÉRIO DA SAÚDE, 2019)

De acordo com o Ministério da Saúde, os principais sinais e sintomas que podem indicar a Síndrome de Burnout são: cansaço excessivo, físico e mental; dor de cabeça frequente; alterações no apetite; insônia; dificuldades de concentração; sentimentos de fracasso e insegurança; negatividade constante; sentimentos de derrota e desesperança; sentimentos de incompetência; alterações repentinas de humor; isolamento; fadiga; pressão alta; dores musculares; problemas gastrointestinais; alteração nos batimentos cardíacos.

O tratamento desse distúrbio psíquico é feito basicamente com psicoterapia, com acompanhamento de profissionais da saúde, podendo envolver também medicamentos (antidepressivos e/ou ansiolíticos) e variando de acordo com condições de trabalho e mudanças nos hábitos e estilo de vida. Para prevenir a Síndrome, o mais recomendado são estratégias que diminuam o estresse e a pressão no trabalho, condutas que podem ter tão saudáveis e até mesmo simples, como uma boa noite de sono (MINISTÉRIO DA SAÚDE, 2019).

Ainda de acordo com o Ministério da Saúde, as principais formas de prevenir a Síndrome do Burnout são: definir pequenos objetivos na 
vida profissional e pessoal; participar de atividades de lazer com amigos e familiares; fazer atividades que "fujam" à rotina diária, como passear, comer em restaurante ou ir ao cinema; evitar o contato com pessoas "negativas", especialmente aquelas que reclamam do trabalho ou dos outros; conversar com alguém de confiança sobre o que se está sentindo; fazer atividades físicas regulares; evitar consumo de bebidas alcoólicas, tabaco ou outras drogas, porque pioram a confusão mental; e não se automedicar nem tomar remédios sem prescrição médica.

Grande parte das faltas no trabalho é causada por transtornos mentais, o que gera uma série de prejuízos: custos financeiros com o auxílio do INSS, a perda de produtividade e presenteísmo, quando o funcionário está fisicamente no trabalho, mas com a cabeça em outro lugar. As doenças mentais possuem diversas causas - e o excesso de estímulos é uma delas (SENDIN, 2016). "Na era da hiperconectividade, as pessoas são atingidas por uma avalanche de informações na forma de mensagens instantâneas, e-mails, alertas de compromisso, notícias em tempo real e aplicativos de todos os tipos e gêneros" (SENDIN, 2016).

Esses impactos advindos da complexidade são um reflexo do mundo VUCA, termo incorporado ao vocabulário corporativo que significa: volátil, incerto, complexo e ambíguo. Criado na década de 1990 em um contexto militar, o termo VUCA era usado pelo U.S Army War College para caracterizar o mundo pós-Guerra Fria - e esse conceito é facilmente aplicado para explicar o momento atual, com transformações intensas e totalmente disruptivas, que trazem desafios pessoais significativos justamente por romper completamente os padrões tidos como corretos até há pouco tempo (OLIVEIRA, 2017).

Nesse contexto, é nítido perceber uma certa ambiguidade em relação aos jovens, historicamente personagens protagonistas de mudanças, que vivem no mundo VUCA. Diante de tantas complexidades e desafios, o jovem revela certa indiferença silenciosa e até passiva, resultando em uma crescente manifestação de ansiedade crônica - visível, principalmente, nas redes sociais. Com o desenvolvimento da internet e sua capacidade de proporcionar um amplo e formidável acesso às informações, os jovens têm ganhado "superpoderes" ao terem uma capacidade de comunicação global e on-line, uma rede social de relacionamento e um facilitado acesso a qualquer tipo de informação a qualquer hora. 
Contudo, até hoje, temos observado que poucos têm conseguido fazer uso desse cenário de forma positiva e construtiva (OLIVEIRA, 2017). Para lidar com o mundo VUCA, é preciso ser resiliente, flexível, multidisciplinar, tomar decisões rápidas e buscar uma gestão eficiente (FNQ,2018).

O mundo VUCA é entendido como:

Volátil (volatility): As mudanças possuem um volume enorme, com caráter volúvel e dinâmico e velocidade inconsistente, fatores que representam um desafio, mas também uma oportunidade para aqueles que têm compreensão disso e detém maiores chances e recursos para enfrentá-lo. O mundo VUCA não dá espaço para quem age de forma passiva como crítico em vez de fazer algo com essa volatilidade. Essas características dificultam a capacidade das empresas e dos funcionários de acompanharem o mercado, que está em rápida e constante transformação.

Incerto (uncertainty): No mundo VUCA, nada mais é previsível mesmo com análises baseadas em dados presentes, existe uma incapacidade de prever resultados futuros. Padrões são destruídos de forma rápida e devemos perceber essas novas abordagens para saber lidar com as incertezas. Do contrário, perde-se a percepção da realidade, pois ter certezas irrevogáveis não se sustenta, principalmente quando percebemo-nos diante de suposições ou informações superficiais no geral. Vale lembrar que, no contexto corporativo, a imprevisibilidade é o principal elemento que dificulta a aplicação de novas soluções.

Complexo (complexity): A natureza interconectada e interdependente do mundo VUCA dificulta a ação e a previsão dos resultados das decisões tomadas em ambientes complexos, em um contexto de difícil compreensão ou entendimento. É necessário usar os talentos de que dispomos para simplificar a complexidade, nos desprendendo da falsa impressão de que complexidade corresponde a qualidade.

Ambíguo (ambiguity): O mundo VUCA é caracterizado pela falta de clareza e concretude, onde se vive uma realidade turva com transformações intensas dos significados. É essa interpretação dúbia dos fatos que dificulta a capacidade de encontrar a relação entre causa e efeito e a solução para determinado fenômeno. Nesse contexto, é vital fazer uma escolha e absorver as consequências, uma vez que não há mais soluções ou respostas precisas e específicas. E tomar decisões dentro de um contexto ambíguo é grande ato de coragem (FNQ, 2018; OLIVEIRA, 2017). 
O ambiente corporativo está cada vez exigente, repleto de informações, procedimentos, comunicações confusas, burocracias, lideranças ineficazes, estresse, correria, e funcionários insatisfeitos (ANDRADE, 2018).

Colaboradores insatisfeitos contribuem para piores resultados nas organizações. Além disso, a complexidade dos processos, o elevado esforço para poucos resultados, assim como a ansiedade e a falta de energia que fazem parte desse contexto, só potencializam a insatisfação e a infelicidade. (ANDRADE, 2018, p. 23)

Os profissionais estão infelizes e sem entusiasmo, sofrendo de sintomas como apatia e ansiedade no trabalho. Muitas pessoas estão trabalhando de maneira mecânica, revoltadas e sem motivação, em meio a uma competitividade desenfreada (diferente de competição), enxergando o cliente como alguém que atrapalha (ANDRADE, 2018). "Existe hoje um comando automático na mente dos adultos que diz: 'Eu não tenho tempo' ou 'Está tudo muito corrido'. Para onde será que estamos correndo, e aonde queremos chegar, se nem paramos para desfrutar o presente?" (ANDRADE, 2018, p. 127).

Trabalhar muito não significa trabalhar bem ou da melhor forma possível. Trabalhar até tarde não demonstra maior comprometimento ou produtividade. Importante é trabalhar em um ritmo sustentável para não consumir todo o tempo e energia, sempre com foco no objetivo (ANDRADE, 2018). "Os profissionais de tecnologia mudaram o mundo, trazendo-nos a inovação, assim como um número inimaginável de informações que nos levam ao estresse e à ansiedade em querer dar conta de tudo ao mesmo tempo" (ANDRADE, 2018, p. 17).

\section{Modelos}

\subsection{Modelos ágeis}

Como forma de responder às mudanças no mundo e no mercado, e ao mesmo tempo sanar grande parte dos efeitos que essa realidade vem trazendo aos funcionários e às empresas, estudam-se e 
implementam-se métodos ou metodologias ágeis. Os métodos ágeis são uma alternativa inteligente à gestão tradicional de projetos, partindo do princípio da adaptabilidade com entregas incrementais e ciclos interativos. Existem várias metodologias ágeis, todas caracterizadas como um conjunto de práticas eficientes e eficazes para entregas rápidas e de qualidade, nas quais o projeto está alinhado às necessidades do cliente e aos objetivos da empresa. As metodologias ágeis são um exemplo do êxito da implementação da simplicidade (METODO ÁGIL, 2001).

O Manifesto Ágil, criado em 2001 por desenvolvedores de softwares nos Estados Unidos, é o documento que norteia os métodos ágeis com excelência, permitindo a mudança na forma de pensar das pessoas. Ele parte de 4 valores:

1. Indivíduos e interações com foco nas pessoas e na forma com a qual se relacionam e trabalham;

2. Funcionamento do software com foco em um programa funcional para suprir as demandas do cliente;

3. Colaboração com o cliente com foco nas parcerias entre fornecedores e clientes;

4. Resposta a mudanças com foco na flexibilidade para suprir as necessidades dos clientes (MANIFESTO ÁGIL, 2001).

Essa mudança de paradigma significa que os processos, ferramentas, documentações, contratos e planos passam a ter importância secundária no desenvolvimento de projetos. Ao colocar o foco nas pessoas, nos softwares, no cliente e nas respostas às mudanças, é possível alcançar projetos de forma mais produtiva, com mais rapidez e qualidade (MANIFESTO ÁGIL, 2001).

Uma das metodologias ágeis mais conhecidas utilizadas no mercado é o Scrum. Ela é uma metodologia ágil de trabalho em equipe para gestão e planejamento, em que o propósito está em unir pessoas com diferentes conhecimentos para atingir um objetivo único e comum, com unidade de propósito e clareza desse objetivo. A partir do modelo de fluxo, no qual a produção flui de forma rápida, porém calma durante todo o processo, o Scrum consegue eliminar os desperdícios, agilizando as entregas de forma colaborativa. Há uma mudança do conceito de "trabalhar mais" para "trabalhar mais rápido" (ANDRADE, 2018). 
A metodologia Scrum se inicia a partir do backlog, com a criação de uma lista com tudo aquilo que o projeto precisará para seu devido desenvolvimento, ou o que o produto ou serviço demanda para ser finalizado e entregue (DESENVOLVIMENTO ÁGIL, 2013-2014).

Na essência, o Scrum se baseia em uma ideia simples: quando se começa um projeto é fundamental verificar os intervalos regulares e curtos - Sprints -, se ele está indo no caminho certo e se é realmente aquilo que os clientes querem. Além disso, o aprimoramento da forma de trabalhar é constante, para obter resultados melhores e mais rápidos, eliminando o que está impedindo a equipe de atingi-los. (ANDRADE, 2018, p. 57)

Essa metodologia ágil é muito eficiente para atingir bons resultados nas empresas - contudo, a maior dificuldade está em sua implementação. Isso porque para colocá-la em prática, é necessário mudar a forma de pensar - ou o mindset - dos profissionais, desenvolvendo atitudes e habilidades - ou soft skills - como comunicação e inteligência emocional. Foi partindo desse desafio e baseando-se no Manifesto Ágil que a A \& B Consultoria e Desenvolvimento Humano, onde Susanne Andrade é sócia-diretora, criou o Modelo Ágil Comportamental (MAC) (ANDRADE, 2018).

Além do Scrum, outras metodologias ágeis mais utilizadas no mercado são a XP, a Lean e o Kanban (AS 5 METODOLOGIAS..., 2018).

A metodologia XP (Extreme Programming) é baseada na agilidade no desenvolvimento, na economia de recursos e na qualidade do produto final. Para alcançar esses pilares, ela valoriza o feedback, a coragem, o respeito, a comunicação e a simplicidade. Exemplos de sua aplicação são os small releases: prática de comunicação que mantém o cliente sempre informado quanto ao andamento do projeto. Por sua vez, o cliente sempre diz o que está achando do processo de desenvolvimento (feedback) (AS 5 METODOLOGIAS..., 2018).

Lean (Lean Software Development) é uma metodologia baseada no famoso sistema Toyota de produção. Ela consegue alcançar baixos custos e alta qualidade de entrega. Com o objetivo de ser uma metodologia aplicável a qualquer empresa, ela institui o uso de nada além 
dos recursos necessários para realizar um projeto. Nela percebemos o cuidado para evitar desperdícios, excesso de processos, códigos incompletos, defeitos e até mesmo a criação de documentos. Um exemplo de sua aplicação são equipes inteiras que compartilham a responsabilidade pela qualidade do projeto, tirando o peso que uma vez foi exclusivo do gestor (AS 5 METODOLOGIAS..., 2018).

Já o Kanban caracteriza-se como um método de controle e gestão visual, no qual cartões coloridos (post-its) são fixados em murais ou outro local comum aos funcionários da empresa com informações sobre o projeto, primordialmente dividido em 3 fases: to do (tarefas a serem feitas), doing (tarefas sendo executadas) e done (tarefas concluídas). "Essa facilidade de visualização e interpretação, faz com que a comunicação entre os funcionários seja muito mais rápida e efetiva e todos saibam exatamente as tarefas que precisam ser feitas e as que já foram realizadas" (ABRANTES, 2018). "O grande diferencial do mundo ágil é desacelerar para conectar as pessoas por meio de um propósito maior em um ambiente colaborativo" (ANDRADE, 2018, p. 17).

\section{Modelo japonês de administração}

Ainda sobre o tema eliminação de desperdícios, é importante falar sobre o modelo de administração japonês e sua relação com a simplicidade no trabalho. O sistema Toyota de produção é uma das bases desse modelo, que está ancorado na filosofia de "eliminação completa de todo e qualquer desperdício". Eliminar desperdício significa reduzir ao mínimo a atividade que não agrega valor ao produto. No sistema Toyota, há três grandes formas de desperdício: Muda (todas as formas de desperdício); Muri (sobrecarga ou trabalho sob tensão, resultando em problemas de qualidade e segurança) e Mura (flutuação na carga de trabalho).

Quando eliminamos ou reduzimos ao mínimo indispensável os desperdícios, nos resta o esforço, responsável por agregar valor ao produto. Agregar valor é transformar aqueles materiais estritamente relacionados à elaboração do produto. O oposto de agregar valor é desperdiçar (MODELO JAPONÊS DE ADMINISTRAÇÃO, [201-]). 
No sistema Toyota, os dois princípios fundamentais são o Jidoka e o Just in time; e o Kaizen é a ferramenta que faz o sistema se aprimorar continuamente. Resumidamente, o Jidoka é um processo de autonomação (automação com toque humano); Just in Time é uma técnica que consiste em fabricar apenas a quantidade necessária, quando necessário, e no volume necessário. Uma das suas ferramentas é o Kanban. Já o Kaizen, que significa aprimoramento, é uma ferramenta de práticas de melhoria contínua (MODELO JAPONÊS DE ADMINISTRAÇÃO, [201-]).

Nos anos 1990, o modelo japonês deixou de ser exclusivamente japonês, tornando-se o padrão universal das empresas que pretendem alcançar e manter a capacidade de competir em escala global. É possível afirmar que o sucesso das empresas japonesas está nas técnicas simples (MODELO JAPONÊS DE ADMINISTRAÇÃO, [201-]).

\section{Aplicação da simplicidade no trabalho}

"O sucesso está em não complicar e fazer o simples: simples de falar, de desenhar, de mostrar. O simples convence! Algo simples fascina, seduz e cativa qualquer um" (BENVENUTTI, 2016, p. 64). Apesar de algumas pessoas acreditarem que para convencer alguém de suas ideias ou fazer benfeito é preciso usar termos difíceis, americanizados, na verdade o que ocorre é justamente o contrário: simples tem o poder de impactar melhor e com maior força. São justamente as expressões básicas e acessíveis que conseguem aproximar as pessoas e suas ideias (ANDRADE, 2018).

Existe uma cadeia muito simples que determina o fluxo de nossa vida e do que queremos conquistar: o meu pensamento interfere em minha emoção, que por sua vez vai determinar a minha ação/ atitude e os resultados que quero conquistar. (ANDRADE, 2018, p. 71)

A simplificação é reconhecida como pilar de um mindset gerencial que ocorre por meio de processos ágeis, eficiência e foco naquilo que é essencial, no core business da empresa. Trazer simplicidade ao trabalho é facilitar a atuação das empresas em diversos âmbitos - processo esse inspirado nas dinâmicas das startups. A simplificação de processos, espaços, 
transporte, documentos, pessoas e equipamentos ajuda as empresas a eliminarem complexidade e investirem nas pessoas: "o tempo e a energia das pessoas são as grandes vítimas da complexidade" (NEVES; LACERDA, 2018).

A Cia de Talentos é um exemplo de empresa que mudou seu espaço físico com o objetivo de simplificar suas operações. A antiga estrutura estava dando muito trabalho, exigindo tempo, energia e atenção, com posições ociosas (por conta de horários flexíveis, reuniões, atuações em campo e home office). Cerca de 120 pessoas foram transferidas para a WeWork, rede mundial coworking avaliada em 20 bilhões de dólares. A empresa decidiu otimizar, promover o desapego e fazer uma limpeza geral, dispensando tudo aquilo que não fosse essencial, desde papéis e arquivos até móveis e bibliotecas. A simplificação fez brilhar os olhos, e sua operação ficou mais leve sinônimo de simplicidade (NEVES; LACERDA, 2018).

A mudança da Cia de Talentos fez com que os métodos ágeis "acontecessem organicamente":

Um espaço simplificado pode convidar a processos mais ágeis, como avaliações em tempo real, erro permitido com aprendizado quase instantâneo, tomada de decisão rápida. Quanto menos entraves físicos, mais as coisas fluem. (NEVES; LACERDA, 2018, p. 64)

Pesquisa realizada pela consultoria Deloitte, em 2015, com 3,3 mil executivos de 106 países, revelou que 71\% deles acreditam que a simplificação do trabalho é item prioritário. Para simplificar, é preciso providenciar uma reengenharia de processos, desapegando do supérfluo e se desfazendo de preocupações com espaço, transporte, documentos, pessoas e equipamentos. Isso faz com que as pessoas conquistem mais tempo e energia para focar $100 \%$ nas atividades-chave, ou, até, fazendo sobrar horas para o descanso e reenergização (NEVES; LACERDA, 2018).

A General Eletric também exerceu a simplificação por meio de um processo batizado de "Simplification", em 2012, no qual, dentre outras atitudes, horizontalizou sua hierarquia, aboliu as apresentações em Power Point, exigiu que seus executivos condensassem relatórios em apenas 1 página e que funcionários usassem aplicativos de feedback com dois botões, "continue assim" e "reconsidere". De acordo com o 
CEO da GE Brasil, "essa cultura requer uma nova forma de pensar e liderar, a fim de trabalharmos de maneira mais ágil, mais simples e com maior foco no cliente" (NEVES; LACERDA, 2018).

A simplificação também pode estar presente nos vínculos empregatícios, tanto para a empresa quanto para o trabalhador, o que vai de acordo com o que a nova geração almeja hoje: somar experiências, e não formar carreiras perenes. Ela está presente também nas relações de parcerias, seja com universidades, startups ou fornecedores em geral.

Uma ideia de modelo que determina que os sistemas devem ser o mais simples possível é chamado "Keep It Simple, Stupid". A complexidade sempre deve ser evitada, pois quando algo é simples, é garantido um nível maior de aceitação e interação do usuário. O "Keep It Simple, Stupid", ou abreviado, "KISS", é utilizado em disciplinas variadas, como design de produtos, design de interface e desenvolvimento de software (GONZALES, 2017).

O primeiro registro do uso da palavra foi na marinha dos EUA, creditada a Kelly Johnson. Principal Engenheiro no Lockheed Skunk Works, Johnson disse aos designers da empresa que seus projetos deveriam ser suficientemente simples para serem reparados por qualquer homem dentro de uma situação de combate que tenha uma noção básica de mecânica e com ferramentas simples. Se os produtos não fossem simples e fáceis de entender, além de custar vidas, tornariam-se obsoletos (GONZALES, 2017).

Quando tratamos de design da experiência do usuário, o princípio do "KISS" leva em consideração que os usuários que levam vidas ocupadas evitarão rapidamente um design complexo. Em exemplos como designs de dispositivos móveis, que muitos usuários acabam utilizando seus smartphones apenas com uma mão, essa filosofia é ainda mais importante (GONZALES, 2017).

Maeda (2007) afirma que atingir a simplicidade na era digital tornou-se uma missão pessoal. Ele propõe 10 leis que considera úteis na busca pela simplicidade no design, na tecnologia, nos negócios e na vida. Essas leis são classificadas em três níveis de simplicidade: básica, intermediária e profunda.

A simplicidade é uma qualidade que não apenas desperta a fidelidade apaixonada pelo design de um produto, mas também se tornou 
uma ferramenta estratégica-chave para as empresas confrontarem suas próprias complexidades intrínsecas. (MAEDA, 2007, p. 4)

De acordo com Maeda (2007), as dez leis da simplicidade são: Reduzir; Organizar; Tempo; Aprender; Diferenças; Contexto; Emoção; Confiança; Fracasso e A Única.

No último nível de simplicidade, a profunda, está a sétima lei, "Emoção", que explica que "é melhor mais emoção que menos", conceito bem exemplificado em um caso de personalização pelo cliente, no qual a emoção é usada para alcançar a simplicidade. A décima e última lei, chamada "A Única", entende que "a simplicidade consiste em subtrair o óbvio e acrescentar o significativo", e dessa forma, ela "simplifica" as outras leis expressando o senso de simplicidade e, diretamente relacionada a ela, de significado (MAEDA, 2007, p. 89).

A difusão da busca pela simplicidade constituiu uma tendência inevitável, dada a estrutura do ramo da tecnologia, que vende a mesma coisa 'nova e aprimorada', onde com frequência 'aprimorada' significa simplesmente mais. (MAEDA, 2007, p. 4)

Andrade (2018) explica que para alcançar o simples, adquirindo uma nova atitude mental e indo em direção ao sucesso na vida pessoal e profissional, devemos seguir um método de sete atitudes: 1 . Identifique seu propósito; 2. Invista em sua inteligência emocional; 3. Assuma o protagonismo, ouse e tenha atitude; 4 . Construa um ambiente colaborativo; 5. Lidere de maneira humanizada; 6. Flexibilize, inove e dê adeus ao medo de errar; 7. Encante seus clientes.

Empresas e pessoas que se baseiam em seus propósitos são aquelas que obtêm maior sucesso: alinhar atitude com essência por meio daquilo que há de mais genuíno. Uma das formas de alcançar o sucesso é por meio do design thinking. "O design thinking é a abordagem para resolução de problemas complexos centrada no ser humano, baseada em empatia, colaboração e experimentação" (ANDRADE, 2018, p. 78-79).

Realizado em três etapas, o design thinking permite chegar aos resultados desejados pelas pessoas, rentável para o negócio e de forma simples, tecnicamente possível. São elas: 
1. Imersão: ter empatia, colocando-se no lugar do cliente para conhecê-lo melhor, entender seus problemas, ouvir seus desejos e saber como melhor atendê-lo.

2. Ideação: surgimento de insights e ideias realizadas em conjunto.

3. Prototipação: experimentar, testar, com a liberdade de errar.

Uma das formas de alcançar realização pessoal e profissional é investir em sua inteligência emocional. "Ter inteligência emocional corresponde à sua conexão com o SER, o seu SER na relação com os outros, com as coisas, com o mundo" (ANDRADE, 2018). De acordo com o criador desse conceito, o psicólogo Daniel Goleman, ter inteligência emocional (IE) significa identificar suas emoções com facilidade e lidar bem com elas e com as pessoas. A IE é classificada em dois domínios principais: competências pessoais e competências sociais.

As competências pessoais dizem respeito à capacidade da pessoa de saber identificar suas próprias emoções, conhecer seus próprios limites e possibilidades, se superar e adaptar, ter integridade, iniciativa, autocontrole, autoconfiança e bastante otimismo. Já as competências sociais dizem respeito à capacidade do indivíduo de se conectar com os outros de forma positiva, contribuindo com o seu crescimento, liderar e influenciar as pessoas de modo inspirador, trabalhar em equipe, gerenciar conflitos, contribuir para o desenvolvimento e a transformação das pessoas com colaboração e empatia.

O exercício da empatia é fundamental para gerar aproximação e conexão. Para isso, é necessário identificar os pontos comuns que se tem com os outros, colocando-se no lugar do outro a fim de entender o que você sentiria se estivesse na situação dele. De acordo com Andrade (2018, p. 57), a empatia "representa a compreensão de sentimentos e emoções, com o intuito de experimentar de maneira objetiva e racional o que sente o outro indivíduo" e, além disso, afirma que esse é um processo "que começa em nossa mente e nos ajuda a dar um novo significado, mais construtivo, ao relacionamento humano".

Para Susanne (2018), ser exemplo significa "fazer aquilo que você espera e deseja que as pessoas façam". Vale lembrar que não é preciso ser líder para liderar. Lideramos pessoas e grupos diferentes em situações diferentes e, com essas atitudes muito simples, a liderança se torna mais leve e humanizada. O mundo ágil demanda profissionais com autogestão 
e postura de líder servidor, que praticam o feedback, fazem boas perguntas, celebram conquistas, exercitam a empatia e servem como exemplo.

Relativamente ao item 6., sobre a flexibilização e a inovação: profissionais de sucesso hoje são aqueles que sabem flexibilizar e inovar, estão abertos para mudanças e não tem medo de errar. Como já mencionado, vivemos em uma época em que é preciso "desaprender o aprendido (medos) e aprender o desaprendido (coragem) da época em que éramos crianças" (ANDRADE, 2018, p. 152).

No Vale do Silício, são consideradas empresas de sucesso aquelas que ousaram experimentar, que erraram várias vezes para depois acertar.

É incrível como, diferentemente das crianças, os adultos sofrem por antecipação e não tomam decisões com medo de errar. Esse comportamento leva à frustração e ao arrependimento. Sem ter saído do lugar por medo, as pessoas se perdem, ignoram seus propósitos, esquecem seus objetivos. (ANDRADE, 2018, p. 155)

"O que parece tão simples para uma criança é complicado para os adultos - porque eles mesmos complicam". (ANDRADE, 2018, p. 157).

Quando seguimos nosso propósito e flexibilizamos, sem medo de errar, conseguimos inovar e criar estratégias para que as coisas deem certo, seja na área de tecnologia, da educação, da saúde, em grandes empresas, em pequenas startups, seja na vida ou na carreira. Fazer isso é integrar-se ao mundo ágil, no qual o poder da simplicidade é a base para o nosso sucesso, em sintonia com a felicidade. (ANDRADE, 2018, p. 158)

Mudar a atitude mental é mudar a forma pela qual enxergamos a vida - "e é a partir dessa mudança de mindset que se conquista uma mudança real [...]. Depois de tanto desgaste e complexidade, as pessoas buscam hoje a simplicidade, com maior leveza na vida e na carreira. É o caminho para o aumento de produtividade, o que vivemos nos modelos ágeis" (ANDRADE, 2018, p. 196).

Hoje, líderes estão exercitando cada vez mais a simplicidade na maneira de se comunicar e se comportar com seus colaboradores, por 
meio de estratégias claras e objetivas, com o intuito de tornar a execução das tarefas e as ações do dia a dia mais simples também. Quanto mais confiantes e seguros de seus conhecimentos e competências, mais utilizam a prática da simplicidade em sua liderança no trabalho (SHINYASHIKI, 2017).

A simplicidade se torna assim a virtude dos grandes profissionais e dos grandes gênios também. Einstein dizia que se você não consegue explicar algo de forma simples, significa que você não o entendeu suficientemente bem. (SHINYASHIKI, 2017)

\section{Metodologia}

\section{Tipo de pesquisa}

O trabalho é composto por pesquisa bibliográfica, realizada por meio de livros, revistas e artigos acadêmicos e gerais, bem como por pesquisas de campo com profissionais por meio de entrevista e questionários. A entrevista foi realizada com uma profissional especialista no assunto, professora, doutora e coordenadora da PUC-SP, residente em São Paulo. O primeiro questionário, com 16 perguntas, foi feito com 20 alunos da FEA-PUC de São Paulo, atuantes no mercado de trabalho há mais de um ano em diversas áreas e empresas, sejam eles estagiários, trainees ou analistas; o segundo e último questionário, com 15 perguntas, foi realizado com 20 gestores que estavam há mais de um ano no cargo de gestão, sejam coordenadores, gerentes ou superintendentes, do Itaú Unibanco S.A., alocados em São Paulo.

A coleta de dados foi feita por meio de pesquisas em livros, artigos e revistas, além da entrevista e questionários. Os dados foram coletados por meio de análise qualitativa e quantitativa. As respostas da entrevista e questionários serviram como suporte para algumas hipóteses sobre a simplicidade no trabalho, sua importância e atuação prática, de acordo com 3 públicos diferentes: especialistas da área, funcionários e gestores. Para cada público foi aplicada uma forma de abordagem específica: a entrevista foi feita presencialmente, por meio de perguntas abertas e entrevistada revelada, enquanto os 
dois questionários (um para alunos/funcionários e outro para gestores) foram feitos por escalonamento Likert.

O questionário por escala Likert teve como opções de respostas: 1 - Discordo plenamente; 2 - Discordo; 3 - Não concordo nem discordo; 4 - Concordo e 5 - Concordo plenamente.

\section{Análise dos resultados}

Com a aplicação da entrevista e dos questionários, é possível analisar e confrontar os objetivos e as hipóteses do trabalho, bem como relacionar as conclusões alcançadas com as ideias dos autores estudados.

Partindo da entrevista, de forma geral, a professora Myrt Cruz entende a simplicidade como uma solução direta a problemas, minimizando gastos e "fazendo mais com menos". Isso é, focar naquilo que importa, entendendo que a simplicidade corresponde a tudo o que não é excesso e desperdício (ANDRADE, 2018). Myrt afirma que a simplicidade é absolutamente imprescindível considerando os tempos atuais, pois entende que a sociedade hoje já é demasiadamente complexa, repleta de infelicidade e insatisfação, características da modernidade líquida.

Sobre os questionários com alunos da PUC empregados em variadas organizações e gestores do banco Itaú Unibanco, é possível fazer uma série de análises. Primeiramente, notamos que diante da afirmação "Atitudes cordiais no trabalho (como "bom dia", "por favor" e "obrigado") fazem o meu dia melhor", a grande maioria dos alunos da PUC concordaram (15\% concordaram, 75\% concordaram plenamente, e 10\% não concordaram nem discordaram) e todos os gestores do Itaú concordaram $(10 \%$ concordaram e $90 \%$ concordaram plenamente). Esse resultado reflete o que Andrade (2018) acredita: atitudes simples, incluindo cordialidades, tendem a conquistar um papel cada vez maior, na vida e principalmente no meio profissional, seja ele qual for. Dessa forma, situações rotineiras como se comunicar com os outros, de forma escrita, oral e visual, não se torna algo complicado. Olhar nos olhos das pessoas e ouvir ativamente demonstrando interesse genuíno são cruciais nesse processo.

Quando questionados se gostam de trabalhar em um lugar com poucas coisas em cima da mesa, como fios, papéis, carregador, 
porta-lápis, post-its, e objetos de escritórios no geral, a maioria dos gestores do Itaú concordam com a afirmação (55\% concorda plenamente e $25 \%$ concorda) e dos alunos da PUC também (40\% concorda plenamente e $40 \%$ concorda. Apenas $1 \%$ de cada público diz que discorda, e ninguém discorda plenamente. Esse resultado demonstra a importância dada ao papel da simplicidade no ambiente físico de trabalho, o qual as pessoas preferem que esteja mais limpo, organizado e sem muitos objetos e informações.

Noventa por cento da amostra de alunos da PUC concorda plenamente que gosta de receber informações e direcionamento dos gestores de forma clara e objetiva (10\% concorda), contudo quando questionados sobre se de fato recebem informações e direcionamentos dessa forma, apenas $40 \%$ concorda com a afirmação, 35\% não concorda nem discorda e $25 \%$ discorda. No caso dos gestores do Itaú, 65\% concordam plenamente que gostam de receber informações e direcionamentos de forma clara e objetiva (25\% concordam e outros $10 \%$ não concordam nem discordam), enquanto $45 \%$ concordam que de fato recebem, $35 \%$ não concordam nem discordam e 15\% discordam.

Curiosamente, diante da seguinte afirmação: "Passo direcionamentos para meus colaboradores de forma clara e objetiva", a maioria dos gestores concorda (60\% concorda e $15 \%$ concorda plenamente). Percebemos aqui que apesar de todos os colaboradores, sejam eles gestores ou não, valorizarem uma comunicação com clareza e objetividade, apenas entre 40 e 50\% afirmam recebê-la em seu trabalho - e mais: $75 \%$ dos gestores afirmam passar informações de forma clara e objetiva (25\% não concordam nem discordam, e nenhum discorda).

De fato, a tarefa de dar e receber direcionamentos no ambiente profissional não é algo trivial como poderia ser. Contudo, para garantir uma boa fluidez e compreensão das tarefas e dos objetivos esperados, é preciso estabelecer uma comunicação mais simples, clara e objetiva dentro da dinâmica do trabalho hoje.

Quando questionados se conseguem explicar de forma simples e objetiva, em uma frase, o que fazem em seu trabalho hoje, $60 \%$ dos estudantes da PUC-SP concordaram que conseguem (35\% concordam e $25 \%$ concordam plenamente), enquanto $85 \%$ dos gestores do Itaú afirmam que conseguem (45\% concordam e $40 \%$ concordam plenamente). 
Percebemos que um número relevante de estudantes (30\% discordam, $5 \%$ discordam plenamente e outros 5\% não concordam nem discordam) não conseguem explicar o que fazem em seu trabalho de forma simples. No caso dos gestores, apesar de o número ser relativamente baixo (10\% discorda e 5\% não concorda nem discorda), é considerável que 15\% não concorde com a frase "Consigo explicar de forma simples e objetiva, em uma frase, o que faço no meu trabalho hoje" por vir de pessoas que estão em cargo de gestão.

De acordo com Shinyashiki (2017), a simplicidade é a virtude dos grandes profissionais e dos grandes gênios - e, como diz a frase comumente atribuída a Einstein, "se você não consegue explicar algo de forma simples, significa que você não o entendeu suficientemente bem". Fica perceptível que ainda há certa dificuldade na comunicação, talvez por conta do próprio entendimento, para que então seja possível comunicar de forma simples. Como explica Andrade (2018), para garantir melhor entendimento de quem ouve, lê ou vê, é importante estabelecer uma comunicação objetiva e transparente. E ainda, de acordo com Benvenutti (2016), entendemos que o sucesso está em descomplicar e fazer o simples: simples de falar, de desenhar, de mostrar. De acordo com ele, "[o] simples convence! Algo simples fascina, seduz e cativa qualquer um" (BENVENUTTI, 2016, p. 64).

Quase a totalidade da amostra, entre gestores e alunos, afirma fazer alguma atividade que poderia ser simplificada e otimizada. Diante dessa questão, $100 \%$ dos gestores do banco (25\% concorda plenamente, o restante concorda) e 95\% dos alunos da universidade (40\% concorda plenamente e 55\% concorda - apenas 5\% não concorda nem discorda) afirmam que há atividades em seu trabalho hoje que poderiam ser simplificadas. Podemos citar Shinyashiki (2017) em diversos pontos deste estudo, pois fica cada vez mais claro que "complicar é fácil, simplificar é difícil".

Diante da frase "Sinto que gasto muito tempo e energia em atividades desnecessárias", notamos respostas bastante divergentes. No caso dos gestores, metade da amostra concorda com a frase (35\% concorda e $15 \%$ concorda plenamente), $40 \%$ não concordam nem discordam e $10 \%$ discordam. Já entre os alunos, $40 \%$ concordam (35\% concordam e $5 \%$ concordam plenamente), $40 \%$ discordam e $20 \%$ não concordam 
nem discordam. De forma geral, observamos, mesmo que talvez discretamente, que muitas tarefas ainda podem ser simplificadas.

Em seguida, sobre a afirmação "Tenho muitas tarefas e pouco tempo para realizá-las - com frequência, não consigo finalizar no prazo", as respostas também foram variadas: $40 \%$ dos gestores concordam (sendo 15\% plenamente), 30\% discordam (sendo 5\% plenamente) e $30 \%$ não concordam nem discordam. Com base nas respostas dos gestores, parece não haver muita sobrecarga de tarefa, ou pelo menos que essa característica varia de acordo com a área ou equipe em que se está. No caso dos alunos, 35\% concordam com a frase (sendo 10\% plenamente), $50 \%$ discordam (sendo 20\% plenamente) e $15 \%$ não concordam nem discordam. Da mesma forma, até mais nitidamente, parece que na amostra não há situações de pressão em realizar muitas tarefas em pouco tempo.

A maioria dos alunos da amostra (60\%) não realiza atividades que não compreende. Diante da frase "Realizo atividades no trabalho cuja finalidade não compreendo", 40\% discordam, 20\% discordam plenamente, $25 \%$ não concordam nem discordam e apenas $15 \%$ concordam (destes, $5 \%$ concordam plenamente). Esse resultado parece estar alinhado com o fato de $60 \%$ dos gestores concordarem com a frase "Consigo deixar meu time alinhado sobre as demandas e expectativas de forma contínua e otimizada", que, ainda que não garanta que deixam claro aos seus funcionários a finalidade das atividades atribuídas a eles, demostra que as demandas e expectativas tendem a estar alinhadas. No caso dos gestores, 55\% concordam com a frase, 5\% concordam plenamente, 25\% não concordam nem discordam, 15\% discordam e 5\% discordam plenamente. Mais uma vez, apesar da maioria concordar com a frase, é considerável que $20 \%$ dos gestores da amostra não consigam deixar o time alinhado de forma contínua.

Diante da afirmação "Uso muitos jargões técnicos durante o meu dia de trabalho", 40\% dos gestores concordam (30\% concordam e 10\% concordam plenamente) e $45 \%$ discordam (40\% discordam e $5 \%$ discordam plenamente) - $15 \%$ não concordam nem discordam. No caso dos alunos da PUC, diante da frase "As pessoas com quem trabalho usam jargões técnicos para dizer algo simples, o que prejudica meu entendimento", 40\% concordam (30\% concordam e 5\% concordam 
plenamente), $50 \%$ discordam ( $25 \%$ discordam e $25 \%$ discordam plenamente) - 15\% não concordam nem discordam. As respostas analisadas não permitem chegar a uma conclusão certa - parece que a amostra de gestores e alunos está bastante dividida quando o assunto é a simplicidade na comunicação verbal. Citando Andrade (2018, p. 196) mais uma vez, "para garantir melhor entendimento de quem ouve, lê ou vê, é importante estabelecer uma comunicação objetiva e transparente".

Outra pergunta do questionário que resultou em respostas bastante distintas foi: "Tenho muitas distrações no meu dia a dia (conversas paralelas, toques de telefone etc.) que prejudicam meu trabalho". No caso dos gestores, $45 \%$ concordam ( $25 \%$ concordam e $20 \%$ concordam plenamente), $30 \%$ discordam ( $25 \%$ discordam e $5 \%$ discordam plenamente) e $25 \%$ não concordam nem discordam. Já os alunos, $45 \%$ concordam (30\% concordam e $15 \%$ concordam plenamente), $35 \%$ discordam (30\% discordam e $5 \%$ discordam plenamente) e $20 \%$ não concordam nem discordam. De fato, a porcentagem de pessoas que concordam com a afirmativa é maior do que a de quem discorda ou não concorda nem discorda. De acordo com Sendin (2016), vivemos hoje na época da hiperconectividade, na qual as pessoas são atingidas por uma avalanche de informações, seja em forma de e-mails, alertas de compromisso, mensagens instantâneas, notícias em tempo real e até aplicativos de todos os tipos - e uma das decorrências do excesso de estímulos são as doenças mentais.

A grande maioria da amostra dos alunos da PUC sente estresse e ansiedade com frequência em seu trabalho - corroborando o que a Isma-BR afirma: no Brasil, nove em cada dez trabalhadores apresentam algum sintoma de ansiedade, do grau mais leve ao incapacitante, e metade (47\%) sofre de algum nível de depressão, recorrente em $14 \%$ dos casos (SENDIN, 2016). Diante da afirmação "Sinto estresse e ansiedade com frequência no dia a dia de trabalho", 50\% dos alunos concordam, $25 \%$ concordam plenamente e $25 \%$ discordam. Já no caso da amostra dos gestores do Itaú, diante da mesma afirmação, $15 \%$ concordam, $15 \%$ concordam plenamente, $25 \%$ discordam e $45 \%$ não concordam nem discordam. De acordo com o Ministério da Saúde (2019), o excesso de trabalho é a principal causa do distúrbio emocional Síndrome de Burnout, cujos principais sintomas são nervosismo, sofrimentos psicológicos, problemas físicos e estresse. 
A maioria da amostra, gestores e alunos, sente que a área em que trabalha possui muitas complexidades e burocracias desnecessárias. $\mathrm{Na}$ amostra de alunos, a porcentagem que concorda é ainda maior: $75 \%$ concordam com a afirmação (50\% concordam e $25 \%$ concordam plenamente), $10 \%$ não concordam nem discordam e $15 \%$ discordam. Fica perceptível, com essas respostas, que a maioria identifica uma grande oportunidade de simplificar os processos dentro de seu trabalho.

Por fim, diante de afirmações sobre metodologias ágeis, é possível concluir que a maioria dos alunos não faz uso delas, contudo gostaria de. E, no caso dos gestores, a maioria acredita que essas metodologias são úteis para fazer seu time trabalhar melhor. Diante da frase "Faço uso de metodologias ágeis no meu trabalho, como Lean, Kanban, Kaizen", 50\% dos alunos discordam plenamente, 25\% discordam, 10\% não concordam nem discordam, 5\% concordam e 10\% concordam plenamente. Já em relação à frase "Não uso, mas gostaria de usar metodologias ágeis no meu trabalho, como Lean, Kanban, Kaizen", 20\% concordam plenamente, $45 \%$ concordam, $30 \%$ não concordam nem discordam e $5 \%$ discordam.

No caso dos gestores, diante da afirmação "Acredito que metodologias ágeis ajudam meu time a trabalhar melhor", 20\% concordam plenamente, $40 \%$ concordam, 30\% não concordam nem discordam e $10 \%$ discordam plenamente. Diante de inúmeras informações, e-mails, mensagens, planilhas e relatórios, reunir todos as tarefas e acompanhamentos em uma informação única, visual e simples de ser interpretada é algo que tem atraído inúmeros gestores (ABRANTES, 2018). E, de fato, essa afirmação parece ser comprovada quando a maioria dos gestores acredita que métodos ágeis são benéficos para uma dinâmica de trabaIho cada vez melhor.

\section{Considerações finais}

Este trabalho teve como objetivo discutir o papel da simplicidade no ambiente profissional, principalmente no mundo de hoje, com foco na simplicidade da comunicação e do ambiente físico de trabalho, além de demonstrar como o incentivo dos gestores e sua adesão às práticas 
descomplicadas no dia a dia com seus times pode trazer um ambiente melhor, com funcionários mais satisfeitos e produtivos. Em relação aos estudos, podemos concluir que o papel da simplicidade parece conquistar importância cada vez maior, na vida e principalmente no meio profissional, seja ele qual for - e que trazer simplicidade no trabalho é facilitar a atuação das empresas em diversos âmbitos.

No contexto do mundo VUCA que vivemos hoje, conectado e apressado, é necessário aprender a lapidar os excessos desnecessários e até prejudiciais ao alcance dos objetivos, tendo a capacidade de filtrar aquilo que realmente importa daquilo que não acrescenta valor. Assim, com o artifício da simplicidade, facilita-se o entendimento para dedicar tempo e energia ao que é mais importante e significativo. Isso faz com que as pessoas conquistem até horas para o descanso e reenergização.

O papel da simplicidade é importante também para amenizar os casos de distúrbios emocionais, como a Síndrome de Burnout ou Síndrome do Esgotamento Profissional, com sintomas de exaustão extrema, estresse e esgotamento físico. Não só: colaboradores doentes e insatisfeitos contribuem para piores resultados nas organizações e, além disso, a complexidade dos processos, o elevado esforço para poucos resultados, assim como a ansiedade e a falta de energia que fazem parte desse contexto, só potencializam a insatisfação e a infelicidade. Diante dessa realidade, algumas empresas têm valorizado jeitos mais simples para lidar com o funcionário por meio da comunicação e do próprio ambiente de trabalho.

Com base nos questionários aplicados, é possível concluir que apesar de muitas opiniões poderem variar de acordo com o perfil do colaborador, da área em que está e das atividades que realiza, a maioria da amostra analisada valoriza atitudes simples e cordiais no trabalho (como "bom dia", "por favor" e "obrigado"), prefere trabalhar em um lugar com poucas coisas em cima da mesa (como fios, papéis, carregador, porta-lápis, post-it e objetos de escritórios no geral), gosta de receber informações e direcionamentos dos gestores de forma clara e objetiva, consegue explicar de forma simples e objetiva o que faz em seu trabalho hoje, faz alguma atividade que poderia ser simplificada, sente que sua área possui complexidades e burocracias desnecessárias e gostaria de usar metodologias ágeis para trabalhar melhor. Além disso, 
a maioria da amostra de alunos sente estresse e ansiedade com frequência em seu dia a dia.

A simplicidade, diferente do simplismo que despreza elementos fundamentais para o entendimento do todo (entendido como uma simplificação exagerada), é a ausência de exageros, artifícios, extravagâncias, tanto na forma física e material como na retórica, na forma de se comunicar, escrever, apresentar, analisar ou resolver um problema. É aquilo que é simples, natural. Simplificar significa, portanto, descomplicar, se desfazer dos exageros, do desnecessário, buscando o fácil entendimento. É o oposto de complicado, e não de complexo. Complicar é fácil, simplificar é difícil. Apesar de alguns ainda acreditarem que para convencer alguém de suas ideias ou fazer benfeito é preciso usar termos difíceis, americanizados, na verdade o que ocorre é justamente o contrário: simples tem o poder de impactar melhor e com mais força. São justamente as expressões básicas e acessíveis que conseguem aproximar as pessoas e suas ideias.

Nesse contexto, as metodologias ágeis, que são muitas, são um exemplo do êxito da implementação da simplicidade - elas representam uma alternativa inteligente, prática e eficaz à gestão tradicional de projetos, partindo do princípio da adaptabilidade com entregas incrementais, rápidas e de qualidade, em ciclos interativos. Pessoas que são incentivadas a trabalhar em ambientes com conceitos mais simples performam melhor e são mais felizes, uma vez que elas não precisam gastar tempo com aquilo que não é importante - conseguem ser objetivas, diretas e expressar suas emoções. De acordo com os argumentos dos autores citados no trabalho e com a professora especialista entrevistada, fica nítida a importância do papel da simplicidade não apenas no trabalho, mas na vida daqueles que estão no mundo VUCA, e como os gestores podem influenciá-la, desde atitudes pequenas como a comunicação verbal cotidiana, até mudanças no modelo de trabalho com seu time.

\section{Bibliografia}

ABRANTES, Letícia. Entenda o que é e como funciona o método Kanban. Rock Content, Belo Horizonte, 15 jan. 2018. Acesso em: 30 out. 2018. 
ANDRADE, Susanne. $\mathbf{O}$ poder da simplicidade no mundo ágil: como desenvolver soft skills e aplicá-las com scrum e design thinking para ter mais resultado com menos trabalho, em menor tempo. São Paulo: Editora Gente, 2018.

AS 5 METODOLOGIAS ÁGEIS MAIS UTILIZADAS. Edit, Lisboa, 28 nov. 2017. Disponível em: https://bit.ly/35K7TTX. Acesso em: 13 nov. 2018. BENVENUTTI, Mauricio. Incansáveis: como empreendedores de garagem engolem tradicionais corporações e criam oportunidades transformadoras. São Paulo: Editora Gente, 2016.

CARDOSO, Silvia Helena. Diferença entre Simplicidade e Simplismo. Blog Mente e Ciência, Campinas, 30 abr. 2017. Disponível em: https://bit. ly/3kfBDM8. Acesso em: 6 nov. 2018.

DE MATTOS, Alessandro Nicoli. Informação é prata, compreensão é ouro. [S.l.], 2009. E-book. Disponível em: https://bit.ly/3bZdRRI. Acesso em: 28 nov. 2018.

DESENVOLVIMENTO ÁGIL. Scrum, 2013-2014. Disponível em: https://bit. ly/32vd6wM. Acesso em: 13 nov. 2018.

FERNANDES, Eda. Qualidade de vida no trabalho: como medir para melhorar. Salvador: Casa da Qualidade Editora Ltda., 1996.

FNQ. Mundo VUCA: o que é e qual a influência na gestão das organizações. FNQ gestão para transformação, São Paulo, 21 dez. 2018. Disponível em: https://bit.ly/2ZAtH0j. Acesso em 23 out. 2019.

GONZALES, Guilherme. Qual a origem do "Keep It Simple, Stupid" (Kiss)?. Ux.blog, São Paulo, 5 set. 2017. Disponível em: https://bit.ly/2RteBFn. Acesso em: 6 nov. 2018.

LISPECTOR, Clarice. A Hora da Estrela. Rio de Janeiro: Editora Rocco, 1977. MAEDA, John. As Leis da Simplicidade. São Paulo: Editora Novo Conceito, 2007.

MÉTODO ÁGIL. Manifesto Ágil, 2001. Disponível em: http://www.metodoagil.com/manifesto-agil/. Acesso em: 13 nov. 2018.

MINISTÉRIO DA SAÚDE. Síndrome de Burnout: o que é, quais as causas, sintomas e como tratar. Brasília (DF), 21 ago. 2019. Disponível em: https://bit.ly/3c5bahM. Acesso em: 30 set. 2019.

MODELO JAPONÊS DE ADMINISTRAÇÃO. Aula ministrada por Antonio Cesar Amaru Maximiano. Publicado na plataforma Coursera. [s. l.], 
[201-]. 1 vídeo (8 min.). Disponível em: https://bit.ly/3hyGOFp. Acesso em: 28 nov. 2018.

NEVES, Emanuel; LACERDA, Ricardo. Simplificação como Ideologia. HSM Management, São Paulo, v. 130, p. 62-69, set./out. 2018.

OLIVEIRA, Sidnei. O Mundo VUCA da Geração Millenials. Exame, São Paulo, 30 dez. 2017. Disponível em: https://bit.ly/2Rv915q. Acesso em: 23 out 2019. SENDIN, Tatiana. Precisamos falar sobre estresse. Você S/A, São Paulo, 13 maio 2016. Disponível em: https://bit.ly/2FGm2Gs. Acesso em: 22 nov. 2018.

SHINYASHIKI, Eduardo. A difícil arte da Simplicidade. Blog VIVA em Alta

Performance, São Paulo, 10 nov. 2017. Disponível em: https://bit.ly/ 2ZDj78U. Acesso em: 28 nov. 2018.

SIGNIFICADOS. Simplicidade. [S. l.], 27 out. 2016. Disponível em: https:// bit.ly/2E3UWJ7. Acesso em: 28 nov. 2018.

SMITH, Daniel. How to Think Like Steve Jobs. Estados Unidos da América: Editora Trafalgar Square, 2014.

TECHOPEDIA. Keep It Simple Stupid Principle (KISS Principle). [S. I.], 5 fev. 2019. Disponível em: https://bit.ly/3mr1O4n. Acesso em: 6 nov. 2018.

\section{Bibliografia recomendada}

ARTIA. Gestão de Projetos: seu guia completo para gerenciar projetos do início ao fim. Joinville, 2018. Disponível em: https://bit.ly/2FETelj. Acesso em: 28 nov. 2018.

BONAVINA, Alvaro. Princípio KISS - Keep It Simple Stupid: um princípio de projeto. Araraquara, 27 jul. 2017. LinkedIn: Alvaro Bonavina. Disponível em: https://bit.ly/3iCaGC3. Acesso em: 6 nov. 2018.

COMPUTER HISTORY MUSEUM. Simplicity is the ultimate sophistication. Mountain View, 2020. Disponível em: https://bit.ly/3hy4fyK. Acesso em: 23 out. 2019.

ÉPOCA NEGÓCIOS. «Open office» diminui estresse e torna funcionários mais ativos, diz estudo. Época Negócios, São Paulo, 10 set. 2018. Disponível em: https://glo.bo/2RrVMSP. Acesso em: 13 nov. 2018. 
INTERACTION DESIGN FOUNDATION. KISS (Keep it Simple, Stupid) A Design Principle. Aarhus, 3 jun. 2019. Disponível em: https://bit. ly/32vcRIf. Acesso em: 06 nov. 2018.

LIMONGI-FRANÇA, Ana Cristina. Qualidade de Vida no Trabalho - QVT: conceitos e práticas nas empresas da sociedade pós-industrial. São Paulo: Editora Atlas S.A., 2004.

SANT'ANNA, Anderson de Souza; KILIMNIK, Zélia Miranda. Qualidade de Vida no Trabalho: abordagens e fundamentos. Rio de Janeiro: Elsevier Editora Ltda., 2011.

SANTOS, Monica. As 10 leis da simplicidade e sua complexa missão no mundo dos negócios. Elos 360, Ribeirão Preto, 22 ago. 2017. Disponível em: https://bit.ly/2E2XUgS. Acesso em: 3 dez. 2018.

SIMPLICIDADE. In: Michaelis On-line. São Paulo: Editora Melhoramentos, 2018. Disponível em: https://bit.ly/2E7sshE. Acesso em: 28 nov. 2018. STARK, Kio. O poder do Acaso: como as pessoas que você não conhece podem transformar a sua vida. São Paulo: Editora Alaúde, 2019.

VASQUES, Victor. A simplicidade é a solução para os nossos problemas. INOVA+, São Paulo, 6 fev. 2018. Disponível em: https://bit.ly/2Rtwrln. Acesso em: 28 nov. 2018. 


\title{
Empresa Júnior: o ex-Júnior e o mercado de trabalho'
}

\author{
Matheus Boyamian Mekhitarian \\ Elisabete Adami Pereira dos Santos
}

\begin{abstract}
Resumo
O trabalho objeto deste capítulo pretendia responder às indagações sobre a contribuição efetiva da participação dos alunos na Empresa Júnior da FEAPUC-SP no desenvolvimento da carreira. O objetivo principal foi, portanto, o de analisar a contribuição da Empresa Júnior no ingresso e desenvolvimento profissional observando o mercado de trabalho. O referencial teórico foi dividido em três pilares: a empresa júnior, o perfil de habilidades demandadas pelo mercado de trabalho e a relação entre ambos. A pesquisa realizada foi de caráter exploratório. Com os dados coletados por meio de 15 questões, 45 estudantes da FEAPUC, sendo 25 ex-juniores, apresentaram suas percepções sobre as vantagens da participação em empresas juniores, principalmente no desenvolvimento de suas soft skills. Os resultados obtidos mostram que os entrevistados acreditam que a empresa júnior é uma importante aliada para o desenvolvimento pessoal e profissional, contribuindo para o ingresso e crescimento no mercado de trabalho, uma vez que são vivenciados, na prática, aspectos teóricos aprendidos e apreendidos durante o curso. Pode-se, então, concluir que ao experimentar situações que a empresa júnior propicia, o jovem é capaz de desenvolver atributos e competências valorizadas pelo mercado de trabalho, aumentando suas chances de ingresso neste e de obter o sucesso profissional.
\end{abstract}

Palavras-chave: Empresa júnior. Mercado de trabalho. Desenvolvimento profissional. Soft skill. 


\section{Introdução}

Compreende-se que na contemporaneidade o mercado de trabalho está cada vez mais disputado e competitivo. Nesse contexto, as universidades estão tendo a necessidade de adaptar-se de modo a facilitar a integração entre o mundo acadêmico e o empresarial e, assim, oferecer melhores condições para o estudante ingressar no mercado de trabalho.

É comum ouvir que a existência de uma empresa júnior no espaço acadêmico ofereceria relações entre teoria e prática de forma a desenvolver conhecimentos e habilidades importantes para a colocação profissional. $\mathrm{O}$ aluno que é inserido nesse tipo de projeto passaria a conviver muitas vezes com clientes reais, situações envolvendo importantes tomadas de decisões, bem como com uma rotina de trabalho.

O Movimento Empresa Júnior tem crescido e ganhado força no Brasil. Estão surgindo federações e confederações por todo o país. Toda essa rede possibilita ao estudante interação com outras faculdades e outros cursos além do seu.

É fato que a boa formação acadêmica não se resume a um conjunto de informações técnicas e científicas, mas define-se como formação integral do indivíduo. Nesse sentido, as Empresas Juniores (EJ) se aproximam mais da formação profissional do que do ensino na sala de aula por si só.

O instrumento do experimento é uma alternativa essencial para essa transmissão de valores. É um modelo de atividade profissional fundamentada no vivencial, ou seja, no desenvolvimento do mesmo conhecimento transmitido de forma prática, sendo caracterizado pelo contato com empresas e empresários e orientação do corpo docente, de modo a capacitar o jovem e fornecer uma experiência de transformação.

Por meio de metodologias embasadas e elaboradas em conjunto e com orientação de professores parceiros, a empresa júnior presta consultoria para pequenas empresas. Além disso, existe toda uma estrutura de suporte à atividade core com as áreas de RH e Marketing e outras atividades dentro do âmbito acadêmico, como a promoção de palestras e workshops.

Considerando a complexidade do mercado de trabalho atualmente, em projeto de pesquisa que deu origem ao trabalho de conclusão de 
curso, foram colocados os seguintes problemas a serem resolvidos: os jovens universitários que foram membros de EJ possuem uma melhor formação? De que forma? O mercado de trabalho reconhece a participação em EJ como um diferencial competitivo?

Os objetivos deste trabalho tinham como foco avaliar a participação de alunos em EJ e o impacto disso no ingresso no mercado de trabalho, bem como o progresso no desenvolvimento de sua carreira. O objetivo específico era avaliar a percepção tanto de juniores quanto não juniores em relação aos benefícios que existem, ou não na participação em EJ.

A hipótese principal do trabalho era que o estudante inserido no ambiente de EJ acaba desenvolvendo habilidades e competências importantes para uma carreira bem sucedida, tanto para o ingresso no mercado de trabalho quanto, posteriormente, no desenvolvimento de sua vida profissional. A segunda hipótese era que ao comparar estudantes que tiveram participação em EJ com estudantes que não fizeram parte, os primeiros levariam vantagem. A participação em EJ forneceria handicap.

Dessa forma, fundamentando-se em referencial teórico apropriado e por meio de pesquisa de campo, foram analisados contextos de graduandos da FEA-PUC a fim de confirmar as hipóteses, concluindo-se que se trata de uma experiência edificante na construção de uma carreira profissional.

Isso tudo somado ao atual cenário extremamente competitivo do mercado de trabalho leva o profissional a buscar cada vez mais recursos e qualificações, com o objetivo de estar mais bem preparado e capacitado para exercer as complexas demandas que o mercado exige. Desse modo, ter no ambiente universitário a possibilidade experimental de trabalhar em uma organização com respaldo de metodologias criadas em conjunto com o corpo docente e com clientes reais é algo que pode qualificar melhor o jovem e dar a ele um diferencial competitivo.

\section{Empresa júnior}


Visando um melhor entendimento da pesquisa, é importante entender o conceito e origem das EJ.

Uma empresa júnior, segundo Matos (1997), é uma associação sem fins lucrativos, gerida por alunos de universidades, cujo objetivo é desenvolver atividades que complementem a formação acadêmica e contribuam ao desenvolvimento de experiências no âmbito pessoal e profissional.

Um conceito semelhante é atribuído pela Brasil Júnior, que por meio da Confederação Brasileira de Empresas Juniores, define da seguinte forma:

Artigo $2^{\circ}$ - As empresas juniores são constituídas pela união de alunos matriculados em cursos de graduação em instituições de ensino superior, organizados em uma associação civil com o intuito de realizar projetos e serviços que contribuam para o desenvolvimento do país e de formar profissionais capacitados e comprometidos com esse objetivo.

Artigo $3^{\circ}$ - A finalidade da empresa júnior deve estar definida em estatuto como: I - Desenvolver profissionalmente as pessoas que compõem o quadro social por meio da vivência empresarial, realizando projetos e serviços na área de atuação do(s) curso(s) de graduação ao(s) qual(is) a empresa júnior for vinculada. (BRASIL JUNIOR, [201-], p. 01)

É importante deixar claro que as EJ devem obrigatoriamente estar registradas perante a Receita Federal e órgãos governamentais como uma pessoa jurídica, de direito privado, associação civil sem finalidades econômicas e com fins educacionais. Toda receita proveniente dos projetos e eventos deve ser reinvestida na empresa e em hipótese alguma pode ser distribuída entre seus membros.

A primeira empresa júnior surgiu na França em 1967, quando estudantes do curso de Administração da ESSEC Business School, ao constatarem as transformações e exigências do mercado, julgaram necessário algo complementar a graduação que unisse a teoria com a prática. Desse modo, nasceu a Júnior-Enterprise que prestava serviços de marketing e finanças. 
O conceito rapidamente foi se espalhando pela Europa e por intermédio do diretor da Câmara de Comércio Franco-Brasileira, João Carlos Chaves, chegou ao Brasil. Em 1989, na Fundação Getúlio Vargas, foi fundada pelos estudantes de Administração a primeira empresa júnior. Os estudantes brasileiros viram nela a possibilidade de minimizar as deficiências de sua formação como administradores (MATOS, 1997).

O movimento contava já em 2016, no Brasil, com mais de 15 mil universitários que todo ano passam por Empresas Juniores. (BRASIL JUNIOR, 2017 apud MONDO, 2019).

O Movimento ganhou força no Brasil e hoje já tem mais de 25 federações, que contemplam um número superior a 900 empresas juniores que entregam mais de 17 mil projetos por ano, transformando o Brasil em país líder no Movimento de Empresas Juniores, superando inclusive os pioneiros da França e demais Europeus, conforme Figura 1.

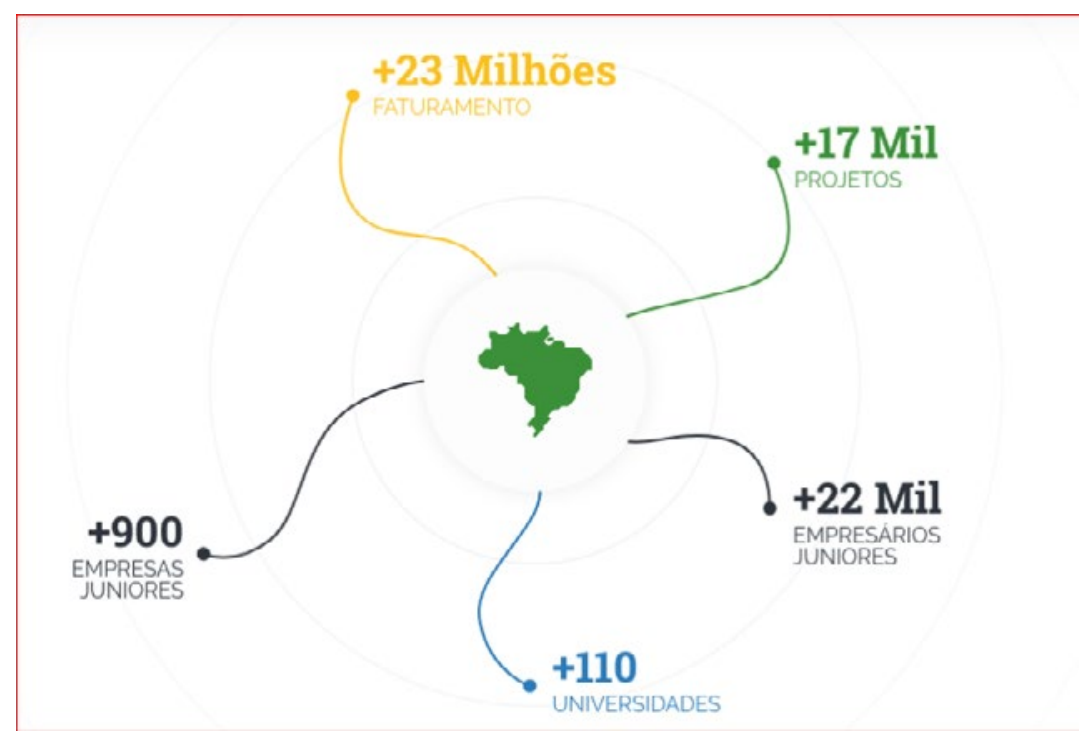

Figura 1. Movimento Empresa Júnior no Brasil, hoje Fonte: Brasil Júnior (2020). 


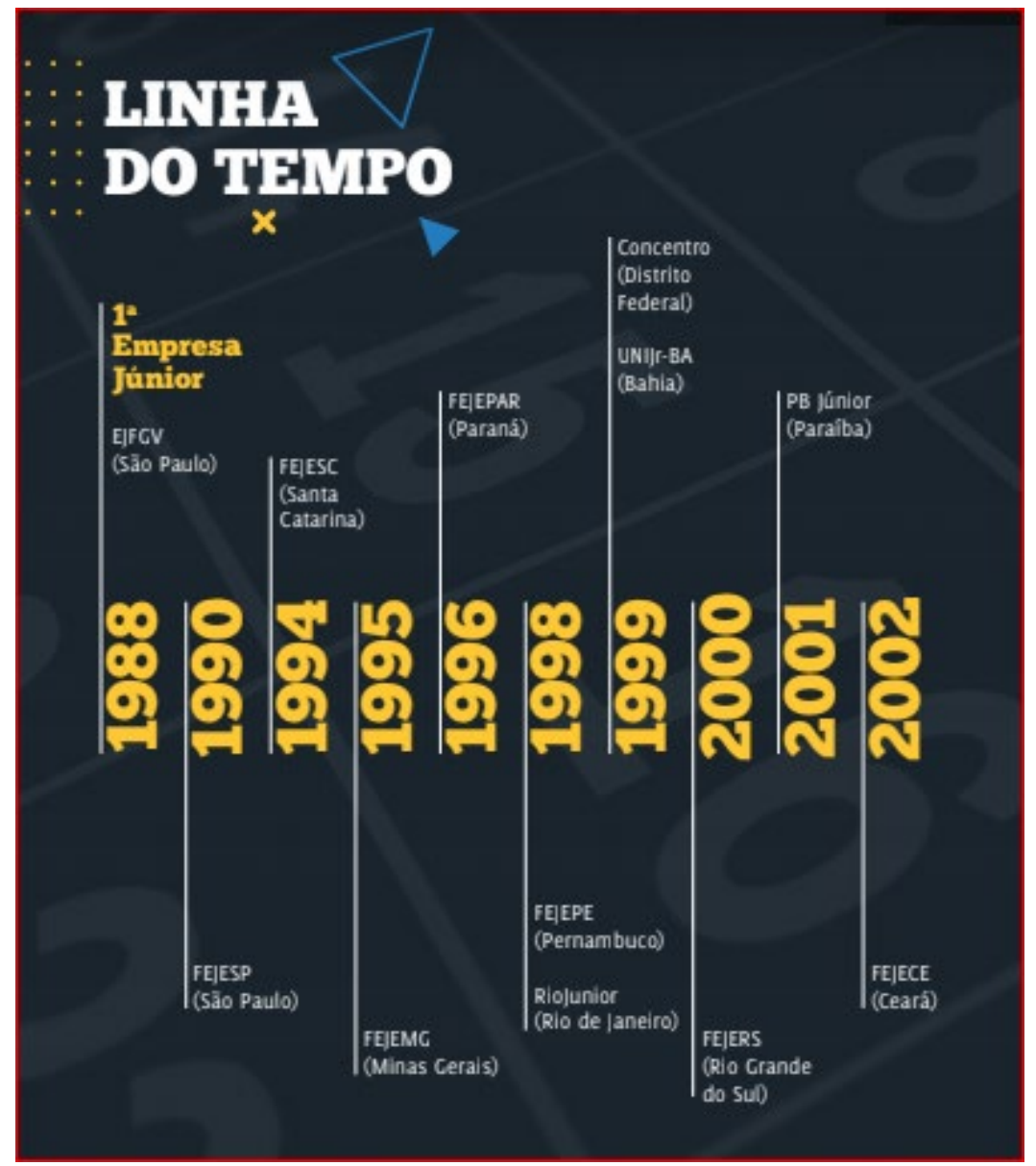

Figura 2. Linha do tempo: A evolução das empresas juniores no Brasil Fonte: Brasil Júnior (2019). 


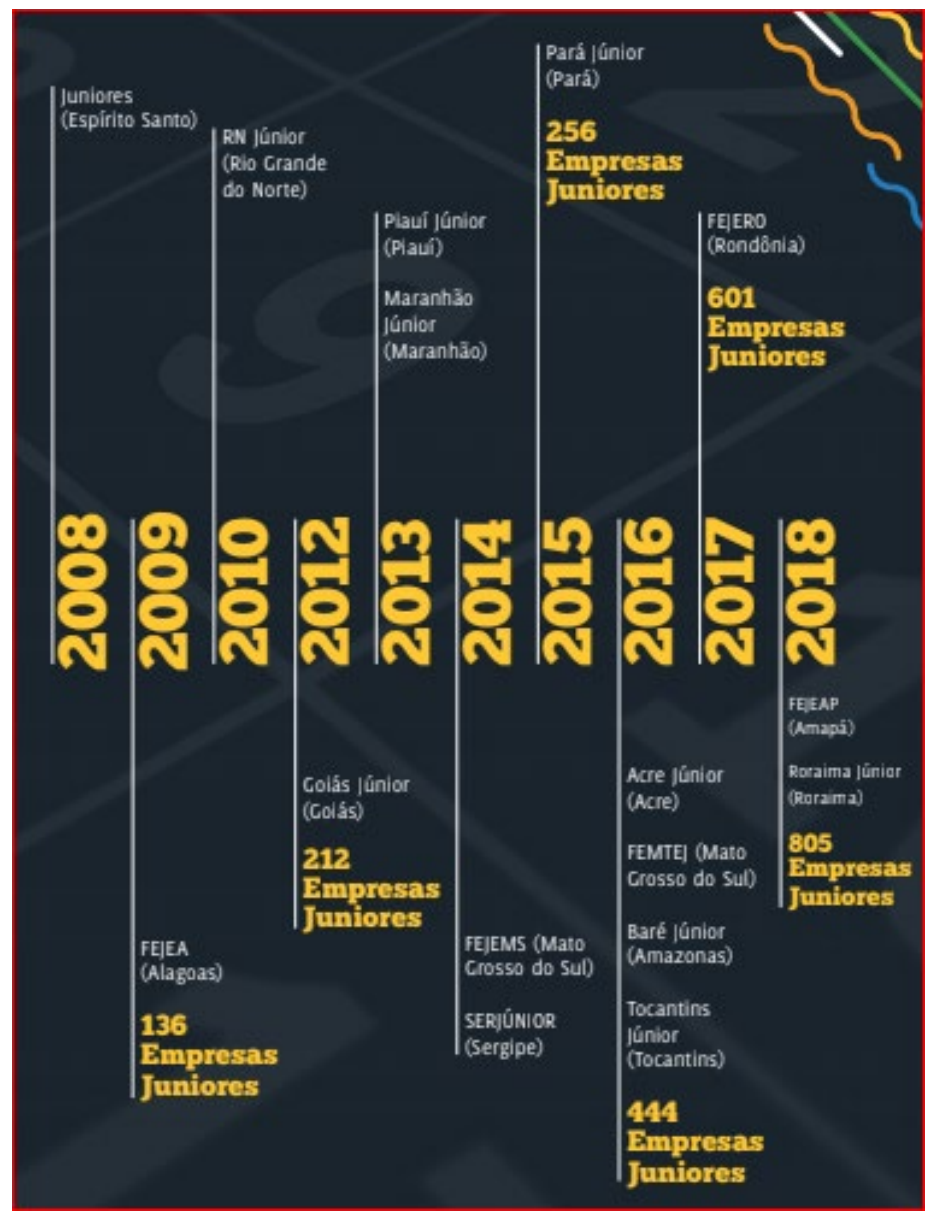

Figura 3. Linha do tempo: A evolução das empresas juniores no Brasil (continuação)

Fonte: Brasil Júnior (2019). 
Por que participar de uma empresa júnior?

A Cia de Talentos, uma das principais consultorias de recrutamento e seleção de jovens do país, definiu 5 motivos para entrar em uma empresa júnior quando o assunto é o ingresso no mercado de trabalho:

\section{Colocar em prática conhecimento das aulas}

Costumamos ouvir bastante dos membros das empresas juniores parceiras que essa é uma das experiências mais enriquecedoras da faculdade. Mesmo com as oficinas, cases, seminários e projetos exigidos na sala de aula, é muito mais fácil colocar em prática o conhecimento teórico aprendido quando você vivencia a realidade da profissão. Uma grande vantagem dessa experiência em relação a um estágio é que, na empresa júnior, um professor estará orientando diretamente as suas atividades, sugerindo mudanças e apontando os melhores caminhos.

\section{Preparação para o mercado de trabalho}

Muitos estudantes só têm a oportunidade de conhecer o dia a dia daprofissãopormeio de umestágioe, para muitoscursos, sóocorre nossemestres finais da graduação. A participaçãoem uma empresa júnior é justamente a possibilidade de se preparar diretamente para o mercado logo nos primeiros semestres da faculdade. Da mesma forma que em uma empresa comum, a júnior pode estar dividida em diversas áreas, como financeiro, administrativo, comunicação, marketing, entre outras. Os alunos candidatos também passam por um processo seletivo com testes e entrevistas. Essa experiência ajuda muito os estudantes que acabaram de sair do ensino médio e nunca tiveram contato com o trabalho em uma empresa.

\section{Desenvolvimento de líderes}

As empresas juniores são administradas pelos próprios graduandos, o que torna possível desenvolver o lado empreendedor, além de aprender na prática temas como gestão financeira e de qualidade, gestão de pessoas, desenvolver protótipos de novos produtos, atuar com recursos humanos, consultoria e planejar projetos para as organizações. 


\section{Aumentar o networking}

As empresas juniores trabalham com clientes, normalmente pequenas empresas, que estão em crescimento e precisam do auxílio em suas áreas administrativas, de marketing, jurídica, comunicação etc. Esse tipo de trabalho é uma oportunidade para os estudantes aumentarem o seu networking, visando o futuro na carreira profissional.

Os membros também têm a oportunidade de ir para conferências, reuniões com outras empresas (juniores ou não) e ingressar na federação do seu estado. Essa é uma forma de aumentar a rede de relacionamentos não só com profissionais de destaque da sua profissão, mas também de outras áreas.

\section{Diferencial no currículo}

Atuar em uma empresa júnior é uma experiência que enriquece o currículo na hora de entrar no mercado de trabalho, seja em um estágio ou vaga efetiva. Os desafios e as situações que você enfrentou e resolveu durante o período que esteve na EJ contam muito para o profissional que está se tornando. (CIA DE TALENTOS, 2017)

De acordo com Cunha (2011 apud BIAVATTI; MARASSI; VOGT, 2014), as EJ oferecem aos alunos oportunidades de interação com o ambiente de negócios, estimulando e desenvolvendo o empreendedorismo nos jovens para que se tornem mais competitivos para o mercado de trabalho.

Para Louette e Lapouge (2011 apud BIAVATTI; MARASSI; VOGT, 2014), a empresa júnior possibilita o desenvolvimento de projetos inovadores que podem impactar positivamente a comunidade na qual está inserida, oferecendo uma experiência profissional prática enriquecedora e gratificante para os que nela atuam (BIAVATTI, MARASSI, VOGT 2014).

\section{Perfil de habilidades demandadas pelo mercado de trabalho}

Este século é muito diferente do século 20. Se compararmos o que eu vivenciei quando jovem, cheio de esperanças e expectativas, 
com o que vivencio agora, em retrospecto, comparando, revisando expectativas e esperanças, eu diria que estamos num estado de interregno. Esse é o termo que gosto de usar. No 'interregno', não somos uma coisa nem outra. No estado de interregno, as formas como aprendemos a lidar com os desafios da realidade não funcionam mais. As instituições de ação coletiva, nosso sistema político, nosso sistema partidário, a forma de organizar a própria vida, as relações com as outras pessoas, todas essas formas aprendidas de sobrevivência no mundo não funcionam direito mais. Mas as novas formas, que substituiriam as antigas, ainda estão engatinhando. (BAUMAN, 2015)

O mercado de trabalho, bem como a sociedade, está em constante mudança, sendo cada vez mais volátil e incerto. A transição da sociedade de produção para a sociedade de consumo trouxe diversas mudanças que atingem as esferas sociais, econômicas e políticas (BAUMAN, 2001, 2015). O processo de globalização vem exigindo mudanças na atuação das empresas e, diante desse cenário, as organizações passaram a demandar profissionais capazes de lidar com a complexidade do ambiente atual, conseguindo responder com velocidade à pressão por resultados e mantendo o alto engajamento com os valores e desafios da empresa.

O mercado de trabalho está cada vez mais interessado no que os profissionais podem trazer de resultado, independentemente do local de trabalho. $\mathrm{O}$ foco passou a ser a produtividade e práticas como as de home office estão começando a aparecer com mais frequência.

Diante desse cenário, quais seriam as principais competências e habilidades demandadas pelo mercado de trabalho?

Para melhor entender o estudo, é importante abordarmos os conceitos de soft skills e hard skills.

Na obra MBA? Não, Obrigado!, Mintzberg aborda uma visão crítica no que diz respeito ao desenvolvimento de gerentes e questiona o foco das universidades em habilidades cognitivas, deixando aspectos relacionados a habilidades de gestão e humanas fora do foco. "Perguntados sobre o necessário para uma melhoria no MBA, os respondentes invocaram mais ensino das 'habilidades sociais e 
de comunicação' (soft skills). Eles sempre fazem tal recomendação" (MINTZBERG, 2004, p. 49). Assim, para o autor, soft skills estão relacionadas a habilidades de comunicação e a habilidades sociais.

Heckman e Kautz (2012) constatam em seus estudos que soft skills são consideradas indicadores de sucesso. Ao publicarem o artigo Hard evidence and soft skills (2012), no qual questionam o uso exclusivo da capacidade cognitiva nos testes de inteligência (OI), excluindo as soft skills da leitura, os autores concluem que o sucesso de uma pessoa recebe grande influência dos traços de personalidade, atributos que não são capturados em testes de cognição.

O sucesso na vida depende de traços de personalidade que não são bem captados por medidas de cognição. Consciência, perseverança, sociabilidade e curiosidade são importantes. Embora os economistas tenham ignorado amplamente esses traços, os psicólogos da personalidade os estudaram ao longo do último século. (HECKMAN; KAUTZ, 2012, p. 452, tradução nossa)

Heckman e Kautz completam que soft skills são os atributos mais valorizados pelo mercado de trabalho. De acordo com os autores, variáveis instáveis como estímulos e incentivos dentro de um contexto, atrelado aos traços de personalidade e comportamento, desenvolvem as soft skills.

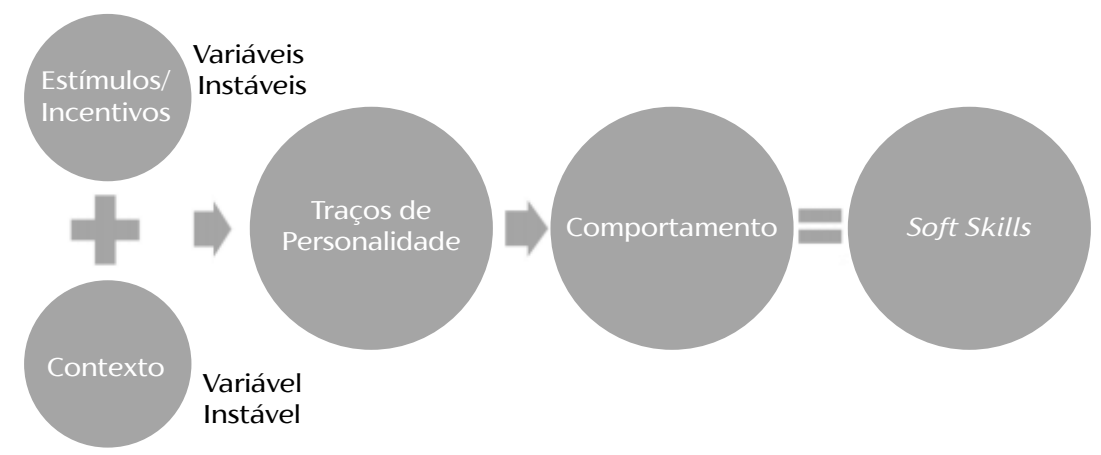

Figura 4. Soft skills de acordo com Heckman e Kautz Fonte: Andrade (2016). 
Rainsbury et al. (2002) colocam que o mercado enxerga as soft skills como complementares das hard skills, tornando-se fator capaz de influenciar o sucesso no desempenho do trabalho. Sendo assim, esses autores sugerem uma possível definição para estes dois blocos complementares:

Hard skills são habilidades relacionadas a aspectos técnicos da realização de um trabalho e geralmente incluem a aquisição de conhecimentos [...].Softskillssãohabilidadesfrequentemente referidas como habilidades interpessoais, humanas, ou comportamentais e colocam ênfase no comportamento pessoal e no gerenciamento de relacionamentos entre as pessoas. (RAINSBURY et al., 2002, p. 9)

Rainsbury et al. (2012) associam as hard skills com o quociente de inteligência (QI) e as soft skills com o quociente emocional (QE). Daniel Goleman, responsável por difundir o conceito de inteligência emocional na década de 1990, a define como a capacidade de identificar seus próprios sentimentos e dos demais, de se automotivar e de aprender a gerenciar emoções e sentimentos.

As pessoas com prática emocional bem desenvolvida têm mais probabilidade de se sentirem satisfeitas e de serem eficientes em suas vidas, dominando os hábitos mentais que fomentam sua produtividade; as que não conseguem exercer nenhum controle sobre sua vida emocional travam batalhas internas que sabotam a capacidade de concentração no trabalho e de pensar com clareza. (GOLEMAN, 1995, p. 49)

Soft Skills consistem em habilidades universais/transversais, não acadêmicas e não relacionadas com a formação ou desempenho de funções técnicas, traços de personalidade, objetivos, preferências e motivações, atributos de carreira, tais como: capacidade de comunicar, de diálogo, de resposta, cooperação com os outros, trabalho em equipe/grupo, capacidade de resolver problemas/ conflitos, motivar, estimular, incentivar, facilitar, apoiar, saber adaptar-se, criatividade, iniciativa, saber comportar-se, etiqueta. [...] Já Hard Skills consistem competências do domínio técnico, 
adquiridas por meio de formação profissional, acadêmica ou pela experiência adquirida ou competências relacionadas com a profissão ou atividade exercida, procedimentos administrativos relacionados com a área de atividade da organização, tais como: saber operar/ manusear máquinas, aparelhos e equipamentos, conhecimento de normas de segurança, conhecimentos de informática/programas, habilidades financeiras/contabilísticas, experiência profissional e técnica. (SWIATKIEWICZ, 2014, p. 678)

Seu objetivo de pesquisa era identificar quais seriam as competências que as empresas valorizavam nos funcionários no momento da contratação, e foi concluído que as soft skills tiveram 78,7\% de relevância, enquanto as hard skills tiveram 14,54\% e as competências morais, 3,76\% de relevância (SWIATKIEWICZ, 2014).

Diante de todo esse cenário mostrando a relevância das soft skills no contexto atual, é possível fazer um paralelo da relação teórico-prática que a experiência dentro de uma empresa júnior proporciona.

Uma vez que as hard skills consistem em competências técnicas adquiridas por meio de formação profissional, a empresa júnior entra com um importante papel complementar que desenvolve aspectos puramente relacionados a soft skills, como capacidade de comunicar, de diálogo, de resposta, cooperação com os outros, trabalho em equipe/grupo, capacidade de resolver problemas/conflitos, motivar, estimular, incentivar, facilitar, apoiar, saber adaptar-se, criatividade, iniciativa, saber comportar-se e etiqueta (SWIATKIEWICZ, 2014).

A experiência em EJ promete desenvolver todos os aspectos mencionados pelo autor e, sendo assim, passa a ser um importante alicerce no ingresso e sucesso no competitivo mercado de trabalho contemporâneo.

\section{A pesquisa}

O estudo teve como objetivo avaliar a percepção dos estudantes da FEA-PUC em relação à participação em uma empresa júnior e a influência disso no ingresso e sucesso no mercado de trabalho. Sendo assim, foi executado um estudo exploratório e explicativo. Anterior à 
pesquisa, foi realizado um levantamento de informações por meio de referências bibliográficas como livros, artigos e publicações.

A pesquisa de campo foi executada com alunos da FEA-PUC que participaram ou não de EJ. O objetivo era ter uma certa equidade entre ex-juniores e não juniores a fim de entender a percepção e avaliação tanto quem fez parte do movimento quanto de quem não fez. No final, foram obtidas 45 respostas, das quais 25 são de ex-juniores e 20 de pessoas que não fizeram parte da empresa júnior.

O questionário foi dividido em duas seções. A primeira para identificação do perfil, com campos quem exigiam respostas no que se diz respeito a gênero, idade, curso, semestre, renda individual e se a posição profissional ocupada demanda gestão de pessoas de subordinados. Na segunda seção, o objetivo era extrair a percepção em relação à experiência de vivenciar um período em empresa júnior. Foi feito o uso da escala de Likert com 5 afirmações e o entrevistado deveria escolher apenas uma das opções, sendo: 1. Discordo plenamente; 2. Discordo parcialmente; 3. Não concordo nem discordo; 4. Concordo parcialmente; e 5. Concordo plenamente.

\section{Análise de dados}

Os resultados da pesquisa obtidos por meio do questionário são apresentados a seguir.

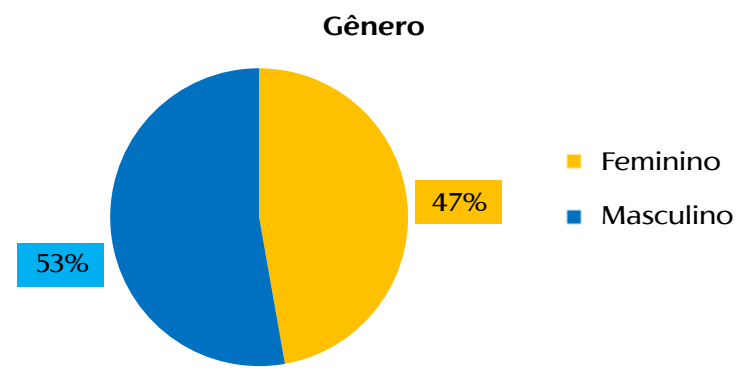

Figura 5. Gênero dos entrevistados

Fonte: Elaborado pelo autor (2019). 
De acordo com a Figura 4, o público masculino representa 53\% das pessoas entrevistadas enquanto o feminino, $47 \%$.

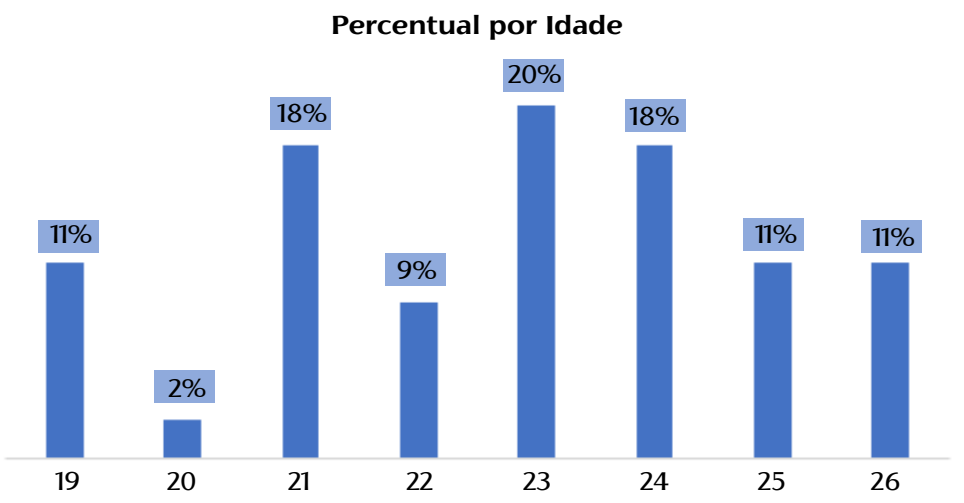

Figura 6. Faixa etária dos entrevistados

Fonte: Elaborado pelo autor (2019).

Como era esperado, uma vez que o questionário foi aplicado em ambiente universitário, a faixa etária contempla estudantes de 19 até 26 anos, tendo a maioria (65\%) entre 21 e 24 anos.

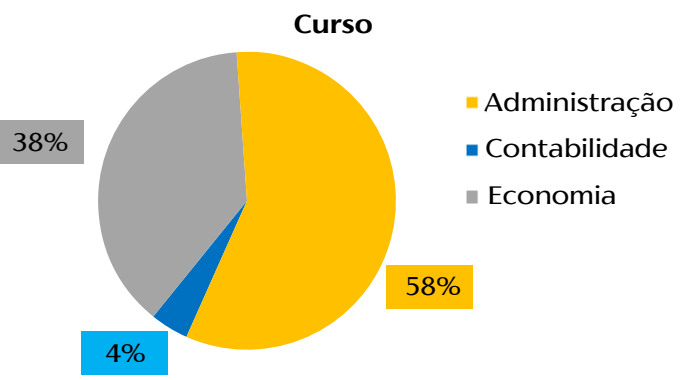

Figura 7. Curso dos entrevistados

Fonte: Elaborado pelo autor (2019).

Aplicado na FEA-PUC, o questionário teve retorno de $58 \%$ de alunos de Administração, 38\% de Economia e 4\% de Contabilidade. 


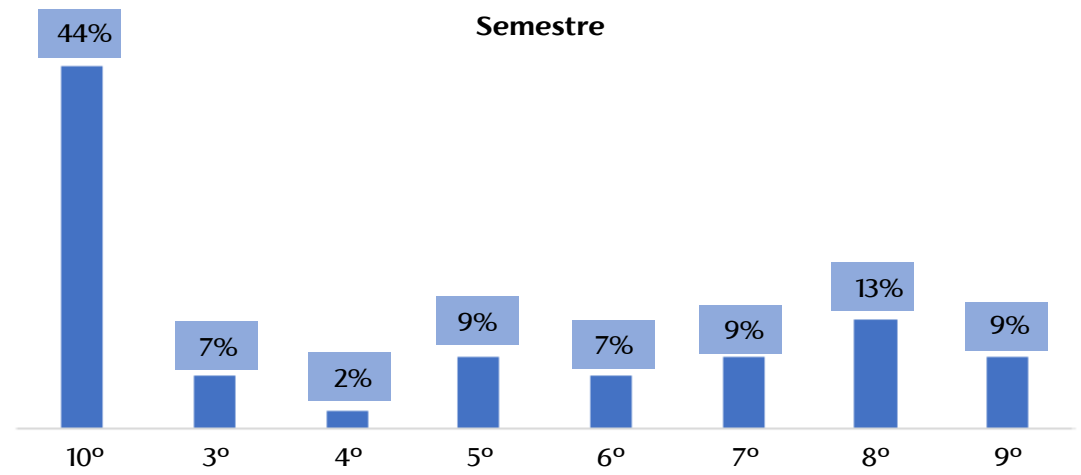

Semestre Semestre Semestre Semestre Semestre Semestre Semestre Semestre

Figura 8. Semestre cursado no momento da pesquisa

Fonte: Elaborado pelo autor (2019).

Grande parte (66\%) dos entrevistados estão nos três últimos semestres do curso, o que para o objetivo desta pesquisa é um dado relevante uma vez que, no final da graduação, o estudante tem uma percepção mais clara sobre o quão relevante para a carreira profissional pode ser a participação em EJ, seja através dos frutos que colheu ou dos que viu os colegas que participaram colher.

Gestão de Pessoas/Subordinadas

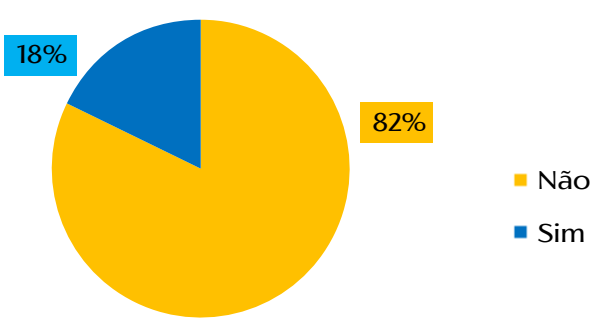

Figura 9. Gestão de pessoas/subordinados

Fonte: Elaborado pelo autor (2019).

De toda a base, apenas $18 \%$ possuem cargo profissional que demande gestão de pessoas de subordinados diretos, conforme mostra a Figura 9. 


\section{Gestão de Pessoas/Subordinadas}

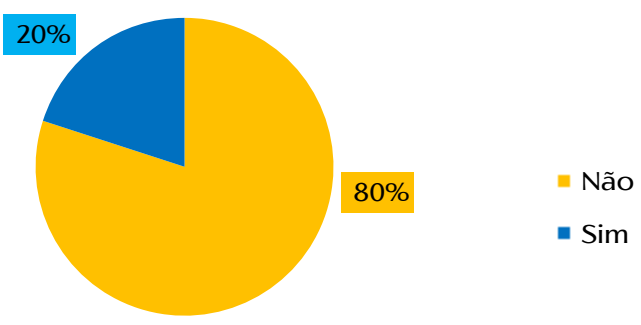

Figura 10. Gestão de pessoas/subordinados (2)

Fonte: Elaborado pelo autor (2019).

Quando analisamos de forma isolada somente as respostas de ex-participantes da empresa júnior, o índice de pessoas cujo cargo demanda gestão de pessoas de subordinados diretos sobe para $20 \%$, como representado na Figura 9. Por se tratar de uma base composta por profissionais com baixa média de idade e que ainda estão cursando a universidade, o número pode ser considerado relevante.

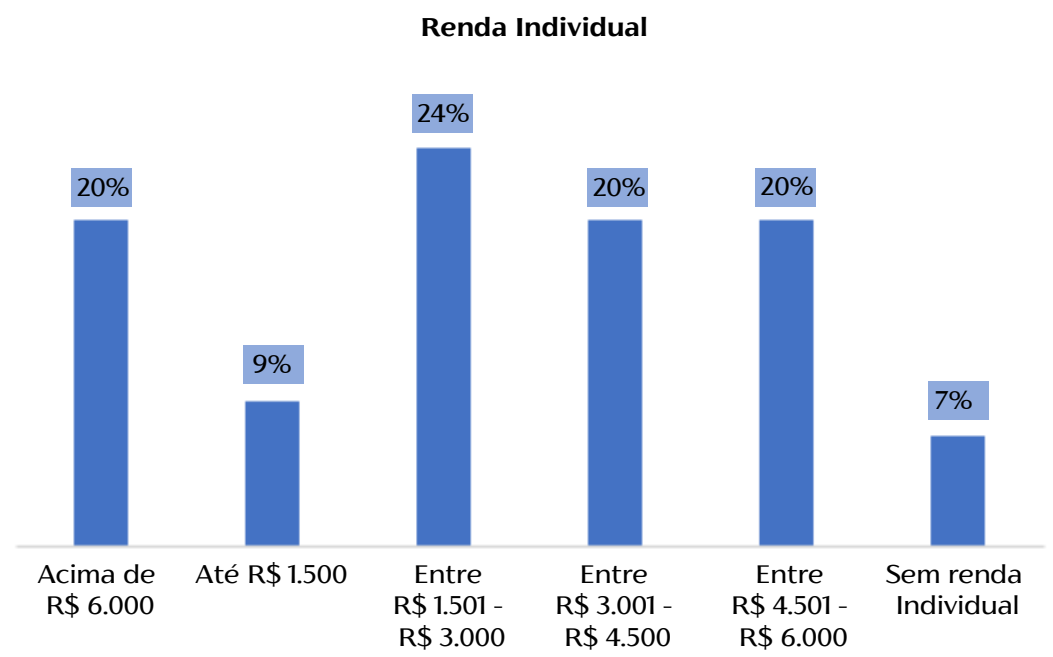

Figura 11. Renda individual

Fonte: Elaborado pelo autor (2019). 
A Figura 10 mostra como de toda a base, a renda individual está bem equilibrada nas faixas entre $\mathrm{R} \$ 1.501$ e $\mathrm{R} \$ 3.000, \mathrm{R} \$ 3.001$ e $\mathrm{R} \$ 4.500$, $\mathrm{R} \$ 4.501$ e R\$ 6.000 e acima de $\mathrm{R} \$ 6.000$.

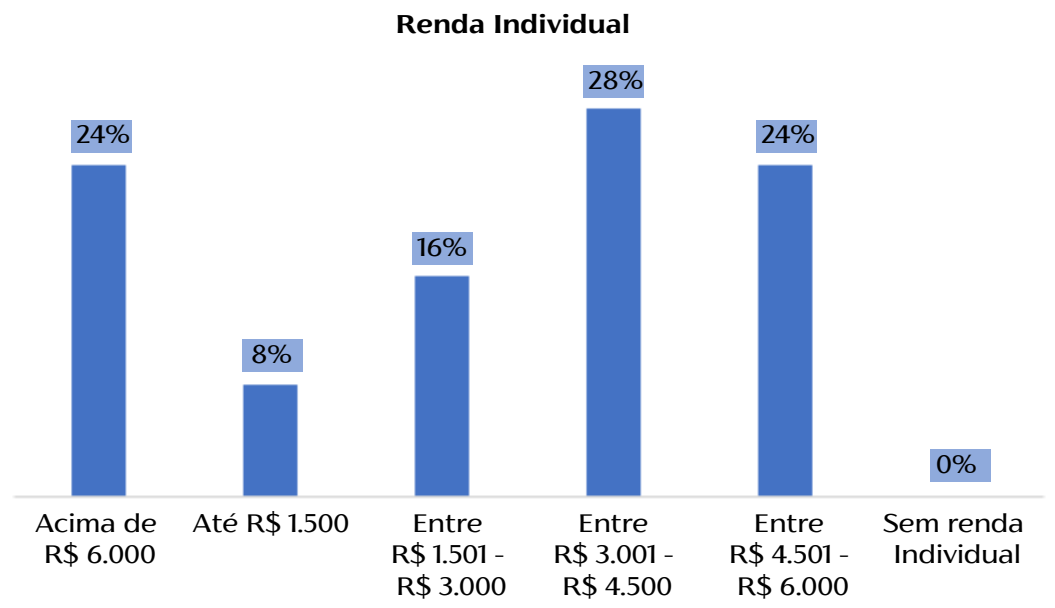

Figura 12. Renda individual (2)

Fonte: Elaborado pelo autor (2019)

Isolando o fator renda apenas dos entrevistados que participaram de EJ, vemos na Figura 11 que há uma melhora significativa no perfil do gráfico, aumentando o percentual de relevância dos maiores ranges. Chama a atenção também a ausência de entrevistados sem renda individual.

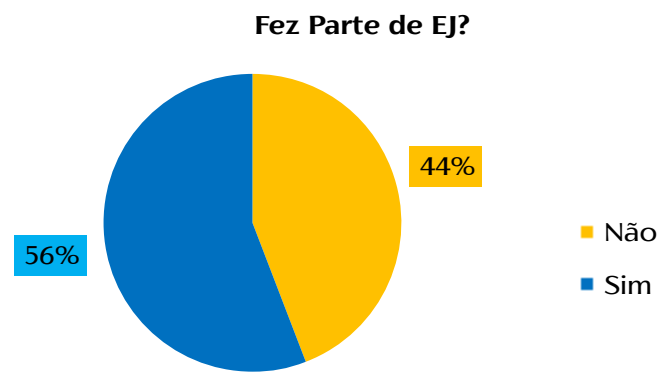

Figura 13. Fez parte da EJ?

Fonte: Elaborado pelo autor (2019). 
Das 45 respostas, 56\% afirmaram ter feito parte da EJ e $44 \%$ que não fizeram (Figura 12).

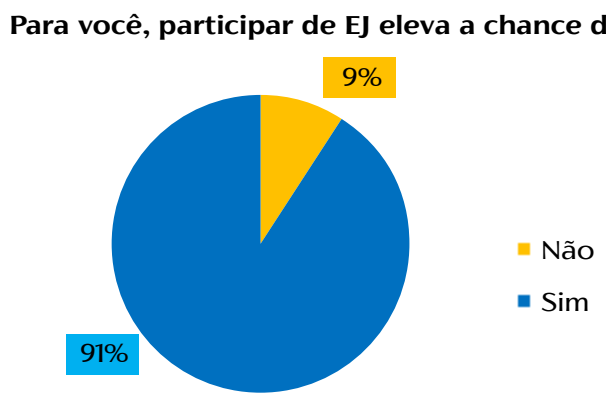

Figura 14. Acredita que a participação em EJ eleva a chance de sucesso profissional?

Fonte: Elaborado pelo autor (2019).

Com 91\% das respostas positivas, a grande maioria, incluso estudantes que não participaram de EJ, acreditam que a participação eleva a chance de sucesso, como mostra a Figura 13.

Tabela 1. Percepção em relação à participação em uma empresa júnior.

Visão geral

\begin{tabular}{|l|c|c|c|c|c|}
\hline $\begin{array}{c}\text { Percepção } \\
\text { em relação à } \\
\text { participação em } \\
\text { uma empresa júnior }\end{array}$ & $\begin{array}{c}\text { Discordo } \\
\text { plenamente }\end{array}$ & $\begin{array}{c}\text { Discordo } \\
\text { parcialmente } \\
\text { concordo } \\
\text { nem } \\
\text { discordo }\end{array}$ & $\begin{array}{c}\text { Concordo } \\
\text { parcialmente }\end{array}$ & $\begin{array}{c}\text { Concordo } \\
\text { plenamente }\end{array}$ \\
\hline $\begin{array}{l}\text { Contribui para o } \\
\text { desenvolvimento } \\
\text { pessoal }\end{array}$ & $0 \%$ & $0 \%$ & $13 \%$ & $22 \%$ & $64 \%$ \\
\hline $\begin{array}{l}\text { Melhora o currículo } \\
\text { Agrega contatos } \\
\text { (networking) }\end{array}$ & $0 \%$ & $2 \%$ & $9 \%$ & $11 \%$ & $78 \%$ \\
\hline $\begin{array}{l}\text { Une a teoria da } \\
\text { sala de aula com } \\
\text { a prática }\end{array}$ & $0 \%$ & $13 \%$ & $27 \%$ & $36 \%$ & $24 \%$ \\
\hline $\begin{array}{l}\text { Desenvolve a } \\
\text { capacidade de } \\
\text { gestão de conflitos e } \\
\text { tomada de decisões }\end{array}$ & $0 \%$ & $2 \%$ & $9 \%$ & $36 \%$ & $53 \%$ \\
\hline
\end{tabular}

Fonte: Elaborado pelo autor (2019). 
Conforme mostra a Tabela 1, de acordo com os 45 entrevistados, a grande maioria (86\%) concorda plena ou parcialmente que há contribuição para o desenvolvimento pessoal. No que diz respeito à melhora de currículo, a aceitação é ainda maior e a resposta "concordo plenamente" atinge 78\% dos entrevistados. Quando a pauta é agregar contatos (networking), a aceitação também foi grande, assim como sobre o desenvolvimento da capacidade de gestão de conflitos e tomada de decisões.

$\mathrm{O}$ atributo que menos teve aceitação de acordo com a percepção dos entrevistados foi o de que a participação em EJ une a teoria da sala de aula com a prática. Esses resultados corroboram a tese de que a sala de aula é um aspecto relacionado a hard skills, enquanto a participação em EJ é algo que desenvolve essencialmente as soft skills na maior parte do tempo.

Tabela 2. Acredita que a participação em EJ eleva a chance de sucesso profissional? Visão de juniores

\begin{tabular}{|l|c|c|c|c|c|}
\hline \multicolumn{1}{|c|}{$\begin{array}{c}\text { Percepção } \\
\text { em relação à } \\
\text { participação em } \\
\text { uma empresa } \\
\text { júnior: }\end{array}$} & $\begin{array}{c}\text { Discordo } \\
\text { plenamente }\end{array}$ & $\begin{array}{c}\text { Discordo } \\
\text { parcialmente }\end{array}$ & $\begin{array}{c}\text { Não } \\
\text { concordo } \\
\text { nem } \\
\text { discordo }\end{array}$ & $\begin{array}{c}\text { Concordo } \\
\text { parcialmente }\end{array}$ & $\begin{array}{c}\text { Concordo } \\
\text { plenamente }\end{array}$ \\
\hline $\begin{array}{l}\text { Contribui para o } \\
\text { desenvolvimento } \\
\text { pessoal }\end{array}$ & $0 \%$ & $0 \%$ & $0 \%$ & $4 \%$ & $96 \%$ \\
\hline $\begin{array}{l}\text { Melhora o } \\
\text { currículo }\end{array}$ & $0 \%$ & $0 \%$ & $0 \%$ & $12 \%$ & $88 \%$ \\
\hline $\begin{array}{l}\text { Agrega contatos } \\
\text { (networking) }\end{array}$ & $0 \%$ & $16 \%$ & $12 \%$ & $40 \%$ & $32 \%$ \\
\hline $\begin{array}{l}\text { Une a teoria da } \\
\text { sala de aula com } \\
\text { a prática }\end{array}$ & $0 \%$ & $0 \%$ & $4 \%$ & $20 \%$ & $76 \%$ \\
\hline $\begin{array}{l}\text { Desenvolve a } \\
\text { capacidade } \\
\text { de gestão } \\
\text { de conflitos } \\
\text { e tomada de } \\
\text { decisões }\end{array}$ & $0 \%$ & & & & $92 \%$ \\
\hline
\end{tabular}

Fonte: Elaborado pelo autor (2019).

Quando isolamos as respostas somente de ex-juniores (Tabela 2), a linha de tendência é igual com os retornos positivos significativamente 
maiores, com retornos acima de $76 \%$ para "Concordo plenamente" em todas as perguntas, com exceção da que propõe que EJ unem a teoria da sala de aula com a prática.

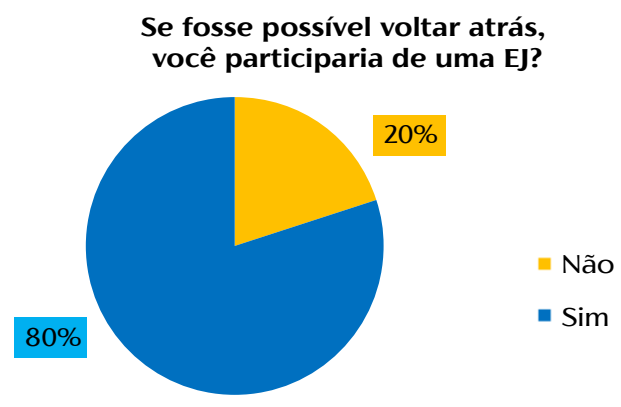

Figura 15. Se fosse possível voltar atrás, participaria de uma empresa júnior? Fonte: Elaborado pelo autor (2019).

Dos entrevistados, $80 \%$ revelaram que se fosse possível, participariam de EJ (Figura 15). Quando isolamos somente os que fizeram parte de EJ, esse número chega a $100 \%$ dos entrevistados. Isolando os entrevistados que não fizeram parte, 55\%, ou seja, mais da metade, afirmaram que se fosse possível voltar atrás, participariam da empresa júnior, reconhecendo-a como um importante diferencial no início da carreira profissional.

Quadro 1. Relatos dos entrevistados

\begin{tabular}{|c|c|}
\hline $\begin{array}{c}\text { Acredita que a participação } \\
\text { na Empresa Júnior eleva a } \\
\text { chance de sucesso na carreira } \\
\text { profissional e de ingresso } \\
\text { no mercado de trabalho? } \\
\text { (Responder mesmo em caso } \\
\text { de não participação) }\end{array}$ & Justifique sua resposta \\
\hline Não & Acredito que é mais válido já arrumar um \\
\hline Não & $\begin{array}{l}\text { Constágio remunerado. } \\
\text { ter feito emprágio nos primeiros semestres sem }\end{array}$ \\
\hline Não & $\begin{array}{l}\text { Para mim, é uma perda de tempo, não vejo } \\
\text { sentido em trabalhar de graça. }\end{array}$ \\
\hline
\end{tabular}

continua na próxima página... 
Quadro 1. Continuação

\begin{tabular}{|c|c|}
\hline $\begin{array}{l}\text { Acredita que a participação } \\
\text { na Empresa Júnior eleva a } \\
\text { chance de sucesso na carreira } \\
\text { profissional e de ingresso } \\
\text { no mercado de trabalho? } \\
\text { (Responder mesmo em caso } \\
\text { de não participação) }\end{array}$ & Justifique sua resposta \\
\hline Não & $\begin{array}{l}\text { Perda de tempo que pode ser dedicado a } \\
\text { outras atividades. }\end{array}$ \\
\hline Sim & $\begin{array}{l}\text { A EJ oferece experiência profissional e } \\
\text { networking, fatores que elevam a chance de } \\
\text { ingresso no mercado de trabalho. }\end{array}$ \\
\hline Sim & $\begin{array}{l}\text { A empresa júnior complementa a formação } \\
\text { do graduando com a experiência prática } \\
\text { voltada única e exclusivamente para seu } \\
\text { desenvolvimento. Muitas vezes um estágio é } \\
\text { um meio do contratante obter uma mão de } \\
\text { obra com bom custo-benefício e, por vezes, } \\
\text { pode deixar a desejar no desenvolvimento } \\
\text { desse jovem. Após participar de uma empresa } \\
\text { júnior, acredito que o estudante tenha um } \\
\text { novo mindset para enfrentar o mercado de } \\
\text { trabalho e certamente estará à frente daqueles } \\
\text { que se limitaram ao conhecimento teórico. }\end{array}$ \\
\hline Sim & $\begin{array}{l}\text { A empresa júnior permite ao aluno descobrir } \\
\text { suas habilidades profissionais, seus pontos } \\
\text { fortes e qual caminho profissional trilhar. } \\
\text { Tenho orgulho de feito parte dessa empresa, } \\
\text { acima, inclusive, de muitas empresas onde tive } \\
\text { o privilégio de participar e ser remunerado } \\
\text { financeiramente. Sou grato por ter conhecido } \\
\text { pessoas incríveis e sei que poderei contar com } \\
\text { elas no futuro, apesar da distância. A Júnior é a } \\
\text { essência do caminho que escolhi. }\end{array}$ \\
\hline Sim & $\begin{array}{l}\text { A experiência em si é uma ótima introdução } \\
\text { ao ambiente corporativo, o que gera maior } \\
\text { maturidade. Além disso, as experiências lá } \\
\text { vividas agregam não apenas ao currículo, mas } \\
\text { também ao se mencionar os projetos, situações } \\
\text { e conhecimentos vividos e adquiridos. }\end{array}$ \\
\hline
\end{tabular}

continua na próxima página... 
Quadro 1. Continuação

\begin{tabular}{|c|c|}
\hline $\begin{array}{l}\text { Acredita que a participação } \\
\text { na Empresa Júnior eleva a } \\
\text { chance de sucesso na carreira } \\
\text { profissional e de ingresso } \\
\text { no mercado de trabalho? } \\
\text { (Responder mesmo em caso } \\
\text { de não participação) }\end{array}$ & Justifique sua resposta \\
\hline Sim & $\begin{array}{l}\text { A empresa júnior dá uma noção melhor das } \\
\text { áreas de uma empresa, pra onde queremos } \\
\text { ir, como se comportar e principalmente } \\
\text { experiência pra começar a carreira. }\end{array}$ \\
\hline Sim & $\begin{array}{l}\text { Acho que ajuda muito no ingresso para o } \\
\text { mercado e para ter experiências diferenciadas } \\
\text { no início da faculdade. }\end{array}$ \\
\hline Sim & $\begin{array}{l}\text { Acredito que a primeira experiência se torna } \\
\text { um diferencial na capacidade de se adaptar a } \\
\text { mudanças e conflitos. }\end{array}$ \\
\hline Sim & $\begin{array}{l}\text { Acredito que não é garantia de sucesso, mas } \\
\text { hoje vejo como um algo a mais. }\end{array}$ \\
\hline Sim & $\begin{array}{l}\text { Acredito que possa ser algo que dê uma certa } \\
\text { vantagem competitiva no início, mas depois } \\
\text { não necessariamente. }\end{array}$ \\
\hline Sim & Acredito que seja uma experiência válida. \\
\hline Sim & $\begin{array}{l}\text { Amigos que fizeram [parte estão] bem } \\
\text { colocados. Porém, optei por dedicar-me à } \\
\text { atlética, o que na minha opinião proporciona } \\
\text { semelhante desenvolvimento. }\end{array}$ \\
\hline Sim & Desenvolvimento pessoal e profissional. \\
\hline Sim & Desenvolvimento profissional. \\
\hline Sim & Diferencial no currículo. \\
\hline Sim & $\begin{array}{l}\text { Embora não tenha feito, acredito que é } \\
\text { um ciclo válido, principalmente aos recém- } \\
\text { ingressados na universidade. }\end{array}$ \\
\hline Sim & $\begin{array}{l}\text { Estou com dificuldade em conseguir estágio } \\
\text { remunerado enquanto vejo meus colegas que } \\
\text { passaram pela empresa júnior entrando em } \\
\text { grandes bancos e multinacionais. }\end{array}$ \\
\hline Sim & $\begin{array}{l}\text { Estou com dificuldades de arrumar estágio e } \\
\text { vejo os ex-integrantes da empresa júnior bem } \\
\text { colocados. }\end{array}$ \\
\hline
\end{tabular}

continua na próxima página... 
Quadro 1. Continuação

\begin{tabular}{|c|c|}
\hline $\begin{array}{l}\text { Acredita que a participação } \\
\text { na Empresa Júnior eleva a } \\
\text { chance de sucesso na carreira } \\
\text { profissional e de ingresso } \\
\text { no mercado de trabalho? } \\
\text { (Responder mesmo em caso } \\
\text { de não participação) }\end{array}$ & Justifique sua resposta \\
\hline Sim & $\begin{array}{l}\text { Estou desempregado e no último semestre. } \\
\text { Vendo meus colegas que fizeram empresa } \\
\text { júnior, percebo o quão à frente eles estão em } \\
\text { termos de desenvolvimento de carreira. }\end{array}$ \\
\hline Sim & Experiência enriquecedora. \\
\hline Sim & $\begin{array}{l}\text { Experiências em entrevistas e nível de } \\
\text { maturidade em relação à postura profissional. }\end{array}$ \\
\hline Sim & Facilita a conseguir o primeiro estágio. \\
\hline Sim & $\begin{array}{l}\text { Facilita a empregabilidade na fase de busca } \\
\text { por estágios. }\end{array}$ \\
\hline Sim & $\begin{array}{l}\text { Hoje vendo meus colegas que fizeram parte } \\
\text { da empresa júnior, constato que estão em } \\
\text { empresas concorridas e subindo de patamar } \\
\text { dentro delas. }\end{array}$ \\
\hline Sim & $\begin{array}{l}\text { Não acho que ajuda no dia a dia do trabalho } \\
\text { em si, mas em situações mais amplas, como } \\
\text { expor suas ideias, fazer apresentações, pensar } \\
\text { em uma solução. }\end{array}$ \\
\hline Sim & $\begin{array}{l}\text { Não tive a oportunidade de fazer porque já } \\
\text { trabalhava quando entrei na faculdade. } \\
\text { Porém, hoje na posição de gestora, vejo com } \\
\text { bons olhos os profissionais que têm essa } \\
\text { experiência no currículo. }\end{array}$ \\
\hline Sim & $\begin{array}{l}\text { No início da minha graduação, eu pensava } \\
\text { que era bobagem, mas hoje, prestes a } \\
\text { me formar, vejo que faz sentido e o quão } \\
\text { importante pode ser. }\end{array}$ \\
\hline Sim & $\begin{array}{l}\text { No primeiro ano, achava que era perda de } \\
\text { tempo, depois, ao acompanhar meus colegas } \\
\text { que fizeram parte, vejo que aos olhos do } \\
\text { mercado é um diferencial. }\end{array}$ \\
\hline Sim & $\begin{array}{l}\text { O mercado vê como um diferencial no início } \\
\text { da carreira (fase de estágio). }\end{array}$ \\
\hline
\end{tabular}

continua na próxima página... 
Quadro 1. Continuação

\begin{tabular}{|c|c|}
\hline $\begin{array}{l}\text { Acredita que a participação } \\
\text { na Empresa Júnior eleva a } \\
\text { chance de sucesso na carreira } \\
\text { profissional e de ingresso } \\
\text { no mercado de trabalho? } \\
\text { (Responder mesmo em caso } \\
\text { de não participação) }\end{array}$ & Justifique sua resposta \\
\hline Sim & $\begin{array}{l}\text { O período na Júnior foi um dos que mais me } \\
\text { desenvolvi na minha carreira até o momento, } \\
\text { isso porque todas as experiências são muito } \\
\text { intensas, principalmente quando falamos } \\
\text { de habilidades comportamentais que farão } \\
\text { muita diferença no início da carreira e serão } \\
\text { importantes para o resto dela. Além disso, } \\
\text { você acaba estando rodeada de pessoas que } \\
\text { têm objetivos similares e elevam a sua régua } \\
\text { em todos os sentidos, ou seja, o ambiente } \\
\text { também propicia que você se desenvolva } \\
\text { desde cedo a ser o melhor que puder ser. } \\
\text { Isso sem contar o networking, que talvez } \\
\text { seja um dos melhores que um graduando } \\
\text { pode ter na universidade para conseguir } \\
\text { melhores estágios que o levarão a ter } \\
\text { melhores empregos lá na frente. }\end{array}$ \\
\hline Sim & $\begin{array}{l}\text { Para trazer responsabilidade, organização e } \\
\text { comunicação. }\end{array}$ \\
\hline Sim & $\begin{array}{l}\text { Participar da EJ foi essencial para complementar } \\
\text { meu currículo e conseguir uma oportunidade } \\
\text { de estágio, seguida de efetivação. Além disso, } \\
\text { foi essencial para meu desenvolvimento } \\
\text { profissional e pessoal. }\end{array}$ \\
\hline Sim & $\begin{array}{l}\text { Pois você desenvolve competências que são } \\
\text { valorizadas no mercado de trabalho. }\end{array}$ \\
\hline Sim & $\begin{array}{l}\text { Possibilita vivenciar situações envolvendo } \\
\text { gestão e tomada de decisão antes da maioria } \\
\text { das pessoas. }\end{array}$ \\
\hline Sim & $\begin{array}{l}\text { Principalmente no início da carreira, a } \\
\text { participação em EJ alavanca a possibilidade } \\
\text { de sucesso e chama a atenção do mercado } \\
\text { de trabalho em um cenário de mercado } \\
\text { extremamente competitivo que vivemos hoje. }\end{array}$ \\
\hline
\end{tabular}

continua na próxima página... 
Quadro 1. Continuação

\begin{tabular}{|c|c|}
\hline $\begin{array}{l}\text { Acredita que a participação } \\
\text { na Empresa Júnior eleva a } \\
\text { chance de sucesso na carreira } \\
\text { profissional e de ingresso } \\
\text { no mercado de trabalho? } \\
\text { (Responder mesmo em caso } \\
\text { de não participação) }\end{array}$ & Justifique sua resposta \\
\hline Sim & $\begin{array}{l}\text { O profissional entra mais preparado para lidar } \\
\text { com o dia a dia. Percebe-se postura diferente } \\
\text { frente aos problemas e atividades desde o } \\
\text { início do estágio. Acredito que o perfil de quem } \\
\text { procura empresa júnior já seja diferente e isso } \\
\text { já é um fator que influencia na postura. }\end{array}$ \\
\hline Sim & $\begin{array}{l}\text { Proporciona experiências interessantes } \\
\text { e estimula competências importantes no } \\
\text { mercado de trabalho. }\end{array}$ \\
\hline Sim & Reconheço como um diferencial. \\
\hline Sim & $\begin{array}{l}\text { Sim, assim como a participação na atlética, } \\
\text { como foi no meu caso. }\end{array}$ \\
\hline Sim & $\begin{array}{l}\text { Sim, pois é um treinamento para o seu futuro } \\
\text { trabalho. }\end{array}$ \\
\hline Sim & $\begin{array}{l}\text { Ter feito parte da Júnior fez com que eu } \\
\text { desenvolvesse uma série de soft skills que vão } \\
\text { além do conteúdo tradicional de uma sala } \\
\text { de aula. Tive experiências em projetos que } \\
\text { me desafiavam e estimulavam o aprendizado } \\
\text { extraclasse. Pude gerir pessoas, projetos e } \\
\text { conhecer diversas pessoas que alavancaram } \\
\text { minha carreira. }\end{array}$ \\
\hline Sim & $\begin{array}{l}\text { Vejo ao comparar as pessoas que fizeram } \\
\text { [parte de] empresa júnior comigo em relação } \\
\text { aos meus colegas de sala. Quem fez parte } \\
\text { tomou a dianteira. }\end{array}$ \\
\hline
\end{tabular}

Fonte: Elaborado pelo autor (2019).

\section{Considerações finais e sugestões para futuras pesquisas}

O trabalho de conclusão de curso teve como objetivo estudar a contribuição que a formação complementar dentro de uma empresa júnior pode ter para o ingresso e sucesso no mercado de trabalho. 
O mercado de trabalho, bem como suas exigências, está cada ano requisitando novas habilidades e qualidades do profissional. Muitas dessas exigências são atributos não ensináveis em sala de aula, o que acaba obrigando os universitários a desenvolvê-las de outras maneiras extraclasse.

Levando em consideração os conceitos de hard skill e soft skill, explorados no trabalho, pode-se fazer um paralelo no qual o ensino e as competências oriundas da sala de aula são hard skills, uma vez que tratam-se de competências de domínio técnico (como habilidades financeiras e contabilísticas), enquanto a experiência dentro da empresa júnior é algo que se relaciona ao desenvolvimento das soft skills à medida que promove as capacidades de comunicação, trabalho em equipe, resolução de conflitos e problemas, motivação e comportamento.

A pesquisa de campo forneceu dados relevantes que corroboram esse comparativo. Quando utilizado o escalonamento de Likert com 5 afirmações (em que o entrevistado deveria escolher apenas uma das opções), para todas as perguntas cujo atributo eram matérias relativas a soft skills (por exemplo, desenvolvimento pessoal, networking e desenvolvimento da capacidade de gerir conflitos e tomar decisões), as opções "concordo parcialmente" e "concordo plenamente" somaram mais de $85 \%$ das respostas, enquanto a questão que propunha que a participação em EJ unia teoria e prática teve uma aprovação bastante inferior.

Reconhecendo que a participação em EJ desenvolve uma série de competências e habilidades que a graduação por si só não é capaz de oferecer, é possível afirmar que os jovens universitários que fizeram parte da empresa júnior possuem uma melhor formação. Referente ao reconhecimento do mercado de trabalho, um dado interessante fornecido pela pesquisa de campo nas informações de perfil diz respeito à faixa salarial do entrevistado. Foi constatado pela pesquisa que os ex-juniores estão em um patamar de renda individual superior aos que não tiveram tal experiência.

De acordo com os autores pesquisados e com a pesquisa de campo aplicada, é aceitável afirmar que a graduação por si só é insuficiente para uma formação que prepare o aluno para obter sucesso no ingresso e no mercado de trabalho. Por fim, diante da complexidade do tema, 
esta pesquisa sugere para um trabalho futuro um exercício semelhante, mas aplicado ao contexto das atléticas dentro da universidade - tanto na parte que diz respeito à gestão quanto na parte esportiva, analisando o impacto e o desenvolvimento de soft skills e do quociente emocional por meio do esporte universitário.

\section{Bibliografia}

ANDRADE, Clarisse Soares Leite de. A influência das soft skills na atuação do gestor: a percepção dos profissionais de gestão de pessoas. 2016. Dissertação (Mestrado em Gestão Empresarial) - Escola Brasileira de Administração Pública e de Empresas, Fundação Getúlio Vargas, Rio de Janeiro, 2016.

BAUMAN, Zygmunt. A fluidez do mundo líquido do Zygmunt Bauman, 2015. Entrevista concedida ao programa Milênio. Disponível em: https://glo.bo/2RgBP1g. Acesso em: 15 maio 2019.

BAUMAN, Zygmunt. Modernidade líquida. Tradução de Plínio Dentzien. Rio de Janeiro: Jorge Zahar Editor, 2001.

BIAVATTI, Vania Tanira; MARASSI, Rodrigo Barraco; VOGT, Mara. A Experiência em Empresa Júnior na Formação Acadêmica e as Possibilidades Empreendedoras na Carreira Profissional. In: Encontro de Estudo de Empreendedorismo e Gestão de Pequenas Empresas (EGEPE), 8., 2014, Goiânia. Anais [...]. São Paulo: Anegepe, 2014. Disponível em: https://bit.ly/33fL4Vb. Acesso em: 28 maio 2019.

BRASIL JUNIOR. Conceito Nacional de Empresa Júnior. [s. l.], [201-].

Disponível em: https://bit.ly/2GqW9uO. Acesso em 1 jun. 2019.

BRASIL JUNIOR. Conheça o MEJ, 2017. Disponível em: https://bit.ly/3I5MxEO. Acesso em 23 set. 2020.

BRASIL JUNIOR. Censo e Identidade: Relatório 2018. [s. l.], 2018a. Disponível em: https://bit.ly/3cPJr51. Acesso em 23 set. 2020.

BRASIL JUNIOR. Jeito BJ, [2018b]. Disponível em: https://bit.ly/34q3wv0. Acesso em: 23 set 2019.

BRASIL JUNIOR. Planejamento Estratégico da Rede Movimento Empresa

Junior 2019-2021. [s. l.], 2018c. Disponível em: https://bit.ly/2Si1Q0T. Acesso em 23 set. 2020. 
BRASIL JUNIOR. Entre o legado e o sonho. Relatório 2018. [s. l.], 2019. Disponível em: https://bit.ly/34muWBA. Acesso em 23 set. 2020.

CIA DE TALENTOS. 5 motivos para entrar numa Empresa Júnior, 2017. Disponível em: https://bit.ly/2FokSQ3. Acesso em: 8 maio 2019.

GOLEMAN, Daniel. Inteligência Emocional: a Teoria Revolucionária que define o que é ser inteligente. 52. ed. Rio de Janeiro: Objetiva, 1995.

HECKMAN, James J.; KAUTZ, Tim. Hard evidence on soft skills. Labour economics, Amsterdam, v. 19, n. 4, p. 451-464, 2012.

MATOS, Franco. A empresa Junior no Brasil e no Mundo: o conceito, funcionamento, a história e as tendências do movimento EJ. São Paulo: Martin Claret, 1997.

MINTZBERG, Henry. MBA? Não, obrigado! Uma visão crítica sobre a gestão e o desenvolvimento de gerentes. Porto Alegre: Bookman, 2004.

MONDO, André Borba. MEJ: um movimento empreendedor. Via Estação Conhecimento, Florianópolis, 5 jun. 2019. Disponível em: https://bit.ly/3iouV5n. Acesso em: 23 set. 2020.

RAINSBURY, Elizabeth et al. Ranking Workplace Competencies: Student and Graduate Perceptions. Asia-Pacific Journal of Cooperative Education, Hamilton, v. 3, n. 2, p. 8-18, 2002.

SWIATKIEWICZ, Olgierd. Competências transversais, técnicas ou morais: um estudo exploratório sobre as competências dos trabalhadores que as organizações em Portugal mais valorizam. Cad. EBAPE. BR, Rio de Janeiro, v. 12, n. 3, p. 633-687, set. 2014. Disponível em: https://bit.ly/32j1wog. Acesso em: 30 maio 2019.

\section{Bibliografia recomendada}

CAVALCANTI, Marília Martins. A Contribuição da empresa Júnior no processo de formação em administração. 2009. Trabalho de Conclusão de Curso (Graduação em Administração) - Universidade Federal de Santa Catarina, Florianópolis, 2009.

FEJESP. Federação das Empresas Juniores do Estado de São Paulo, 2005.

Disponível em: http://www.fejesp.org.br. Acesso em: 3 jun. 2019.

VILLARROEL, Maria Júlia de Almeida. A importância da empresa júnior na formação profissional do estudante de administração. 2016. 
Pesquisa Discente no Curso de Administração da PUC-SP - 2018/2019

Trabalho de Conclusão de Curso (Graduação em Administração) Faculdade de Economia, Administração, Contabilidade a Ciências Atuariais, Pontifícia Universidade Católica, São Paulo, 2016. 


\title{
Hábitos alimentares e nível de atividade física associados a qualidade de vida de estudantes da Faculdade de Economia e Administração da Pontifícia Católica de São Paulo
}

\author{
Daniela Meanda \\ Mauro Maia Laruccia
}

\begin{abstract}
Resumo
Este trabalho tem por objetivo identificar como o Índice de Massa Corporal, os hábitos alimentares e o nível de atividade física impactam na produtividade acadêmica e na qualidade de vida de alunos da Faculdade de Economia, Administração, Contabilidade e Atuária da Pontifícia Universidade Católica de São Paulo. Trata-se de um estudo transversal constituído por 75 alunos do curso de Administração. Os resultados foram coletados por meio de um questionário constituído por perguntas referentes a alimentação, nível de atividade física, hábitos de vida e alimentares, peso e altura para o cálculo do Índice de Massa Corporal. Com isso, foram traçados perfis com a utilização da estatística descritiva. A discussão teórica foi embasada em livros e artigos científicos que relacionam o nível de atividade física, o estímulo pela universidade, hábitos alimentares, tabagismo e etilismo e traçam como essas questões afetam a produtividade e a qualidade vida. A partir do problema de pesquisa sobre como o IMC afeta a qualidade de vida dos estudantes universitários,
\end{abstract}


foi elaborada a hipótese de que a falta de atividade física e hábitos alimentares inadequados prejudicam a qualidade de vida dos estudantes. A partir dos resultados, considerou-se que a qualidade de vida é um assunto discutido nos dias de hoje, visto que buscamos constantemente obter uma boa saúde física e mental e embora o IMC seja o indicador antropométrico mais utilizado, não deve ser utilizado sozinho, e sim traçado com outros índices. Além disso, a universidade tem papel importante na qualidade de vida dos alunos. Novos estudos devem ser realizados, abordando temas como a possibilidade de inserção de universidades em período integral e a necessidade dos jovens de ingressarem cedo no mercado de trabalho, enquanto ainda cursam a universidade, e por esse motivo não dispõem de tempo hábil para a prática de atividades físicas.

Palavras chaves: Índice de Massa Corporal. Qualidade de vida. Hábitos alimentares. Atividade física. Etilismo. Tabagismo. Universitários.

\section{Introdução}

Segundo a Organização Mundial da Saúde (OMS), a definição de qualidade de vida refere-se à percepção pessoal da sua posição na vida, na cultura e sistemas de valores nos quais se está inserido, bem como em relação aos seus objetivos, expectativas, padrões e preocupações (WHOQOL GROUP, 1997).

A busca por um instrumento que avaliasse qualidade de vida dentro de uma perspectiva genuinamente internacional fez com que a Organização Mundial da Saúde desenvolvesse um projeto colaborativo multicêntrico. O resultado desse projeto foi a elaboração do WHOQOL-100, um instrumento de avaliação de qualidade de vida composto por 100 itens (WHOQOL GROUP, 1997).

Determinado pela Organização Mundial da Saúde, recomenda como prática de atividade física moderada e vigorosa para adultos um total de 150 minutos ou mais por semana e preferencialmente divido entre todos os dias (WORLD HEALTH ORGANIZATION , 2000).

$\mathrm{Na}$ sociedade atual, o assunto qualidade de vida vem sendo muito discutido, tendo recebido atenção crescente não somente da literatura científica, mas também de campanhas publicitárias, nos meios de comunicação e plataformas políticas. Além de ser considerada como poderosa expressão no discurso popular, tornando-se 
até mesmo um clichê, é também motivo de interesse de pesquisas de várias áreas especializadas, como: Sociologia, Medicina, Enfermagem, Psicologia, Economia, Geografia, História Social e Filosofia (KAWAKAME; MIYADAHIRA, 2005).

Este trabalho tem como objetivo identificar a qualidade de vida de alunos universitários da FEA-PUC. Especificamente, analisar o Índice de Massa Corporal (IMC) dos estudantes, analisar os hábitos alimentares dos alunos e a forma como se alimentam, analisar o desenvolvimento de doenças advindas de uma alimentação inadequada, identificar o nível de atividade física e o estímulo oferecido pela universidade e identificar como o tabagismo e o álcool influenciam na qualidade de vida.

\section{Problemas e hipóteses de pesquisa}

Problema 1: Como o IMC afeta a qualidade de vida dos estudantes universitários? Hipótese 1: A falta de atividade física e hábitos alimentares saudáveis prejudicam a qualidade de vida dos estudantes.

Problema 2: O hábito de fumar afeta a frequência de atividade física?

Hipótese 2: O hábito de fumar impacta na atividade física dos estudantes da FEA.

Problema 3: O hábito de ingerir bebida alcoólica afeta a frequência de atividade física?

Hipótese 3: O hábito de ingerir bebida alcoólica afeta a atividade física dos estudantes da FEA.

\section{Justificativa}

Traçar o nível de atividade física, hábitos de vida e alimentares de universitários da Faculdade de Economia, Administração, Contabilidade e Atuária da Pontifícia Universidade Católica de São Paulo e identificar como o IMC é importante, pois pode afetar na produtividade acadêmica e na qualidade de vida desses alunos. 
Definição dos termos

Colesterol elevado: Excesso de gordura no organismo.

Diabetes: Elevação de glicose no sangue devido a defeitos na secreção ou ação do hormônio insulina.

Doença Cardiovascular: Classe de doenças que afetam o coração e/ou vasos sanguíneos.

Doença Arterial Coronariana: Obstrução de artérias coronárias (vasos que irrigam o coração e músculos).

Estresse: Resposta física ou mental do organismo a um evento extremo.

Etilismo: Psicopatologia, ação de consumir de maneira excessiva, periódica e/ou permanente álcool, que, por sua vez, pode gerar certa dependência psíquica e/ou física, o alcoolismo.

Hábitos alimentares: Corresponde a o que o indivíduo come com regularidade. $\mathrm{Na}$ área de Alimentação e Nutrição, trata-se de propor soluções para agravos à saúde associados a práticas alimentares.

Hiperglicemia: Excesso de açúcar no sangue.

Hipoglicemia: Baixo nível de açúcar no sangue.

IMC: Índice de Massa Corporal, trata-se de uma medida que compõe a relação do peso e altura de um indivíduo. É um método simples, rápido e permite uma avaliação para definir riscos de saúde.

Nível de atividade física: Refere-se a qualquer atividade ou exercício que tenha como consequência o gasto de energia e coloque em movimento fenômenos a nível corporal, psíquico e emocional no indivíduo que a realiza.

Obesidade: Acúmulo excessivo de tecido adiposo.

Pressão Arterial: Pressão exercida pelo sangue contra a parede das artérias para bombear o sangue.

Qualidade de vida: indica o nível das condições básicas e suplementares do ser humano. Envolvem desde o bem-estar físico, mental, psicológico e emocional, os relacionamentos sociais e parâmetros que afetam a vida humana.

Sedentarismo: Falta ou ausência de atividade física.

Síndrome metabólica: Conjunto de condições que aumentam riscos de doenças cardíacas e diabetes. 
Sobrepeso: Peso em demasia ou excesso.

Tabagismo: Caracteriza-se pela dependência psicológica e química do tabaco.

\section{Discussão teórica}

\section{Índice de Massa Corporal (IMC)}

O Índice de Massa Corporal (IMC) é um dos indicadores antropométricos mais utilizados na identificação de indivíduos em risco nutricional. Isso ocorre em virtude da sua facilidade de aplicação, seu baixo custo e pequena variação intra ou intermedidor (PERISSINOTTO et al., 2002).

Estudos realizados em países desenvolvidos, com amostras representativas de indivíduos adultos de ambos os sexos, demonstraram que o IMC se correlaciona bem com indicadores antropométricos de gordura não visceral, abdominal ou visceral, além de ter relação direta com a massa de gordura corporal total (NAVARRO; MARCHINI, 2000).

Segundo Gardner, a imagem corporal é um importante componente do complexo mecanismo de identidade pessoal definida como "a figura mental que temos das medidas, dos contornos e da forma de nosso corpo; e dos sentimentos concernentes a essas características e às partes do nosso corpo" (1996, p. 327-37).

O estado nutricional expressa o grau pelo qual as necessidades fisiológicas de nutrientes estão sendo atendidas. Uma avaliação do estado nutricional deveria ser rotineira, como parte da atenção primária à saúde no sentido de prevenir o desenvolvimento de quadros mórbidos diversos, além de ser um importante indicador no estabelecimento de atividades educacionais e de intervenção. O IMC é a medida mais comumente empregada em estudos de grupos populacionais para classificação primária do estado nutricional (KAKESHITA; ALMEIDA, 2006).

Enquanto alguns estudos sugerem que pessoas com excesso de peso apresentam maior insatisfação com a imagem corporal, outros demonstram que mesmo naquelas com massa corporal adequada, a prevalência de insatisfação é bastante alta, ou seja, a relação entre estado nutricional e insatisfação com a imagem corporal permanece 
não resolvida. As pesquisas que objetivaram verificar essa relação utilizaram apenas o IMC como medida de estado nutricional. A explicação mais utilizada para essas divergências em relação ao estado nutricional é que parece existir uma preocupação exagerada com a estética corporal, sendo que os padrões de beleza geralmente não correspondem aos padrões tidos como adequados para a saúde. Entretanto, pode-se atribuir como outra possível causa o fato de o IMC não ser um indicador preciso da adiposidade corporal. Nesse sentido, torna-se necessário verificar a associação entre a insatisfação com a imagem corporal e outras medidas de estado nutricional, a exemplo do somatório de espessuras de dobras cutâneas, que, além de manter a praticidade e baixo custo, reflete com melhor exatidão a adiposidade corporal dos indivíduos (COQUEIRO et al., 2008).

Os resultados mostraram que grande número de universitários está insatisfeito com a própria imagem corporal. Em estudos realizados no Brasil, a prevalência de insatisfação com a imagem corporal foi similar à do presente estudo, sendo descritas prevalências de $82 \%$ em escolares e de $76 \%$ e $82 \%$ em mulheres e homens fisicamente ativos, respectivamente (COQUEIRO et al., 2008).

\section{Nível de atividade física e estímulo pela universidade}

A relação da atividade física e da alimentação com a saúde é estudada há muitos anos, sendo que os resultados confirmam que a prática de atividade física regular e uma alimentação equilibrada atuam diretamente na prevenção das doenças crônicas não transmissíveis (MARCONDELLI; COSTA; SCHMITZ, 2008).

O período universitário é um momento de grande importância no que diz respeito à saúde do indivíduo, pois a necessidade de inserção em um novo ambiente e inclusão em um grupo, sentimento de liberdade e independência, além do maior tempo gasto com atividades acadêmicas podem proporcionar também maior exposição a um ambiente favorecedor de práticas não saudáveis (GASPAROTTO, 2012).

Apesar dos benefícios documentados sobre a prática regular de atividade física na melhoria da saúde e na prevenção de doenças crônicas 
não transmissíveis, poucos indivíduos adultos são fisicamente ativos. Mesmo a atividade física no lazer tendo aumentado nos últimos anos, estima-se que a proporção de indivíduos sedentários ou que não obedecem a recomendação mínima de 30 minutos diários de atividade física de intensidade moderada, esteja em torno de $60 \%$ da população global (MARCONDELLI; COSTA; SCHMITZ, 2008).

Ter baixo nível de atividade física é uma condição que está associada ao desenvolvimento de doenças, tais como diabetes, infarto do miocárdio, doença arterial coronariana, câncer e obesidade. É também um dos fatores que contribui para elevar as taxas de mortalidade, aumentar os riscos de hospitalizações e de problemas psicossociais, resultando em custos elevados para a saúde pública de modo geral (PITANGA; LESSA, 2005).

Estudar o nível de atividade física de universitários é importante para a descrição de aspectos relacionados à saúde desse grupo e que podem servir para a adoção de estratégias e programas de saúde na universidade como medida preventiva para a adoção de hábitos de vida saudáveis e a melhoria da qualidade de vida na fase adulta e na velhice. A universidade deve servir para a disseminação de saberes, cultura e valores dos quais as atividades físicas não podem estar excluídas (FONTES; VIANNA, 2009).

\section{Tabagismo e etilismo}

Os estudos sobre o consumo de álcool, tabaco e drogas ilícitas entre universitários têm aumentado nos últimos anos de forma acelerada na tentativa de compreender as características de consumo e o perfil dessa população de interesse. Com isso, busca-se extrapolar dados para a população geral e aprimorar programas de prevenção existentes em instituições de ensino superior (WAGNER; ANDRADE, 2008).

O tabagismo e o etilismo são aspectos bastante estudados entre os estudantes universitários. O sentimento da necessidade de inclusão social e a autonomia na tomada de decisões, incentivados pelas oportunidades geradas na convivência com outros jovens, poderiam aumentar a frequência desses hábitos (GASPAROTTO, 2012). 
O hábito de fumar, juntamente com o consumo de álcool, se insere na rotina do aluno, grande parte das vezes, devido além da exposição, relacionada a frequentes eventos promovidos pelos estudantes, ao sentimento de necessidade de inclusão ao meio social em que se encontram (GASPAROTTO, 2012).

O sedentarismo e o tabagismo apresentam altas prevalências mundialmente. Ambos são fatores de risco para o aumento da morbimortalidade, além de aumentarem os gastos com a saúde (RODRIGUES; CHEIK; MAYER, 2008).

Alguns estudos relatam associação entre sedentarismo e tabagismo. Adolescentes fumantes apresentam menores níveis de atividade física, e a atividade física na adolescência interfere no início do tabagismo nesse período e em sua manutenção na idade adulta (RODRIGUES; CHEIK; MAYER, 2008).

Alguns dados da literatura sugerem que o período da graduação pode influenciar negativamente o consumo de álcool e tabaco, mostrando diferenças nas proporções apresentadas entre alunos com menor tempo de curso comparados aos que estão mais próximos da graduação, entre áreas de estudo e sexos (GASPAROTTO, 2012).

O fumo de cigarros aumenta o risco de mortalidade por câncer, doenças cardiovasculares, cerebrovasculares e doenças respiratórias crônicas. Por outro lado, o exercício físico é considerado fator protetor contra o início do hábito tabagístico e a redução do tabagismo diminui a incidência de doenças (RODRIGUES; CHEIK; MAYER, 2008).

Além das possíveis associações entre a gênese do tabagismo e do sedentarismo, a prática regular de exercícios físicos pode colaborar para o abandono do hábito tabagístico (RODRIGUES; CHEIK; MAYER, 2008).

\section{Hábitos alimentares}

Devido às mudanças ambientais e socioculturais das últimas décadas e o seu papel no quadro atual de produção da obesidade, torna-se relevante conhecer os determinantes do estado nutricional, o universo simbólico e os aspectos subjetivos que permeiam o estilo de vida e o comportamento alimentar. A detecção e o conhecimento 
da magnitude de distorções na percepção da imagem corporal constituir-se-iam importantes dados para a avaliação clínica de sujeitos com risco para o desenvolvimento da obesidade (KAKESHITA; ALMEIDA, 2006).

Nos últimos anos, o Brasil vem passando por um período de transição nutricional, caracterizado pela queda nos índices de desnutrição e aumento das taxas de sobrepeso e obesidade. Esse quadro reflete a influência da industrialização e da importação de hábitos alimentares ocidentais, que são marcados pelo alto consumo de alimentos processados, de baixo teor nutricional e alto valor energético em detrimento da ingestão de frutas, verduras, legumes e cereais integrais (FEITOSA et al., 2010). O aumento do consumo de alimentos industrializados prontos, produzidos a partir de farinha e açúcar refinados e com altas concentrações de gordura saturada, além da diminuição do consumo de frutas e hortaliças, caracteriza uma situação favorável ao crescimento de problemas cardiovasculares, como hipercolesterolêmica, hipertrigliceridemia, aumento da pressão arterial e outros problemas metabólicos (GASPAROTTO, 2012).

Para o jovem adulto, a nova rotina de vida ao ingressar na universidade pode favorecer mudanças consideráveis nos hábitos alimentares. Apesar de as universidades disponibilizarem alguma refeição aos alunos a preços populares, a maior parte da rotina alimentar é de responsabilidade do próprio indivíduo, situação que pode ainda ser agravada pela necessidade de saída da casa da família, mudança de cidade e falta de conhecimento no preparo de alimentos, o que levaria à procura por refeições rápidas e de baixo valor nutricional (GASPAROTTO, 2012).

Os problemas de saúde relacionados à obesidade são temas amplamente estudados na atualidade. A obesidade é tratada como epidemia pela Organização Mundial da Saúde e mostra proporções preocupantes tanto em países desenvolvidos como em desenvolvimento (GASPAROTTO, 2012). Alguns estudos demonstram aumento das prevalências dos problemas de saúde decorrentes do excesso de peso corporal e sugerem que, quando adquiridos na juventude, podem permanecer até idades mais avançadas, levando a complicações metabólicas agudas e crônicas (GASPAROTTO, 2012). 


\section{Procedimentos e métodos}

Estudo transversal com amostra de alunos do curso de Administração da Pontifícia Universidade Católica de São Paulo. Os resultados serão coletados por meio de um questionário onde os estudantes responderão sobre alimentação, nível de atividade física, peso, altura e hábitos alimentares.

Trata-se de uma pesquisa descritiva cujo objetivo foi descrever as características dos alunos do curso de Administração da PUC-SP, levando em conta os aspectos da formulação das perguntas que norteiam a pesquisa, além de estabelecer relação entre as variáveis propostas sobre o objeto de estudo em análise. Foi utilizado procedimento de levantamento de dados através de um questionário aplicado on-line com abordagem quali-quantitativa.

Foi realizado um pré-teste com 12 alunos a fim de verificar se o questionário estava apto para entendimento da amostra total.

Os resultados foram analisados e relacionados com pesquisas bibliográficas para averiguar a qualidade de vida dos estudantes.

\section{População e amostra}

A Faculdade de Economia e Administração da Pontifícia Universidade Católica de São Paulo tinha 1.395 alunos matriculados no curso de Administração no ano de 2018 (população). Esses alunos representam o número de indivíduos com chance de entrarem na amostra sobre a qual serão realizadas as inferências neste estudo.

O número de respostas concluídas recebidas pelo seu questionário é o tamanho da sua amostra. Chama-se 'amostra' porque representa apenas parte do grupo de pessoas (ou população) cujas opiniões ou comportamentos são de seu interesse. Por exemplo, uma forma de obter uma mostra é de maneira aleatória ('amostra aleatória'), na qual os respondentes são escolhidos totalmente por acaso entre a população como um todo. (SURVEYMONKEY, 2018) 
O tamanho amostral, isto é, a proporção dos eventos de interesse/ respostas esperadas na população estudada, foi definida em 70 alunos do curso de Administração para nível de confiança de $95 \%$ e precisão de 5\%, conforme apresentado na Figura 1.

\begin{tabular}{|lc|}
\hline Tamanho da Populção & 1.395 \\
Proporção Populacional & $95,00 \%$ \\
\hline
\end{tabular}

TAMANHO DE AMOSTRA PARA PROPORÇÕES

\begin{tabular}{c|c|c|c|c}
\hline \multirow{2}{*}{ Precisão } & \multicolumn{4}{|c}{ Nível de confiança } \\
\cline { 2 - 5 } & $80 \%$ & $90 \%$ & $\mathbf{9 5 \%}$ & $99 \%$ \\
\hline $10 \%$ & 8 & 13 & 19 & 31 \\
$\mathbf{5 \%}$ & 31 & 50 & $\mathbf{7 0}$ & 116 \\
$3 \%$ & 82 & 130 & 178 & 281 \\
$2 \%$ & 172 & 362 & 344 & 504 \\
$1 \%$ & 501 & 670 & 791 & 968 \\
\hline
\end{tabular}

Legenda:

Tamanho da População $=>\quad$ O número de indivíduos com chance de entrarem na amostra e em relação aos quais serão feitas inferências.

Proporção Populacional => Proporção de eventos de interesse esperados na população.

Precisão =>

Margem de erro para estimação da proporção populacional.

Nível de Confiança $=>\quad$ Probabilidade de acerto no teste de hipóteses e na estimação por intervalo.

Figura 1. Cálculo do tamanho da amostra

Fonte: Elaborado pelos autores (2019).

\section{Questionário}

Foi elaborado um questionário com dezessete perguntas fechadas, tipo dicotômico e tipo múltipla escolha, com a finalidade de descrever o perfil dos alunos (amostra) e uma pergunta aberta que se refere ao problema de pesquisa. O Quadro 1 apresenta as questões, tipologia e seus objetivos. 
Quadro 1. Questões, tipologia e objetivos

\begin{tabular}{|c|c|c|}
\hline Pergunta & Objetivo & Tipo \\
\hline Gênero & $\begin{array}{l}\text { Identificar o gênero dos alunos para } \\
\text { a análise de dados }\end{array}$ & $\begin{array}{l}\text { Feminino } \\
\text { Masculino } \\
\text { Outro }\end{array}$ \\
\hline Faixa etária & $\begin{array}{l}\text { Identificar faixa etária dos alunos } \\
\text { para análise do IMC }\end{array}$ & $\begin{array}{l}18 \text { a } 25 \text { anos } \\
26 \text { a } 30 \text { anos } \\
31 \text { a } 35 \text { anos } \\
36 \text { a } 40 \text { anos } \\
41 \text { a } 45 \text { anos } \\
\text { Acima de } 46 \text { anos }\end{array}$ \\
\hline Período & $\begin{array}{l}\text { Identificar o semestre que o aluno } \\
\text { cursa para comparativo de perfis }\end{array}$ & $\begin{array}{l}1^{\circ} \text { Semestre } \\
2^{\circ} \text { Semestre } \\
3^{\circ} \text { Semestre } \\
4^{\circ} \text { Semestre } \\
5^{\circ} \text { Semestre } \\
6^{\circ} \text { Semestre } \\
7^{\circ} \text { Semestre } \\
8^{\circ} \text { Semestre } \\
9^{\circ} \text { Semestre }\end{array}$ \\
\hline Horário & $\begin{array}{l}\text { Identificar qual horário o aluno cursa } \\
\text { a universidade para comparativo de } \\
\text { perfis }\end{array}$ & $\begin{array}{l}\text { Manhã } \\
\text { Noite }\end{array}$ \\
\hline Peso & $\begin{array}{l}\text { Identificar o peso do aluno para } \\
\text { cálculo do IMC }\end{array}$ & Resposta aberta \\
\hline Altura & $\begin{array}{l}\text { Identificar altura do aluno para } \\
\text { cálculo do IMC }\end{array}$ & Resposta aberta \\
\hline $\begin{array}{l}\text { Área em que } \\
\text { trabalha }\end{array}$ & $\begin{array}{l}\text { Identificar se o aluno trabalha como } \\
\text { estagiário, operacional ou gerência } \\
\text { com a finalidade de realizar um } \\
\text { comparativo entre as áreas }\end{array}$ & $\begin{array}{l}\text { Estagiário (a) } \\
\text { Operacional } \\
\text { (colaboradores) } \\
\text { Tática (gerência média) } \\
\text { Estratégica (alta gerência) } \\
\text { Não trabalha }\end{array}$ \\
\hline $\begin{array}{l}\text { Frequência } \\
\text { que pratica } \\
\text { atividade física }\end{array}$ & $\begin{array}{l}\text { Identificar a frequência semanal } \\
\text { de prática de atividade física para } \\
\text { analisar a qualidade de vida dos } \\
\text { alunos }\end{array}$ & $\begin{array}{l}1 \text { a } 2 \text { vezes na semana } \\
3 \text { a } 4 \text { vezes na semana } \\
\text { Mais de } 4 \text { vezes na semana } \\
\text { Não pratica }\end{array}$ \\
\hline $\begin{array}{l}\text { Possui hábito } \\
\text { de fumar }\end{array}$ & $\begin{array}{l}\text { Identificar se o aluno possui hábito } \\
\text { de fumar com a finalidade de } \\
\text { identificar o hábito de vida }\end{array}$ & $\begin{array}{l}\text { Sim } \\
\text { Não }\end{array}$ \\
\hline
\end{tabular}


Quadro 1. Continuação

\begin{tabular}{|c|c|c|}
\hline Pergunta & Objetivo & Tipo \\
\hline $\begin{array}{l}\text { Possui hábito } \\
\text { de ingerir } \\
\text { bebida } \\
\text { alcóolica }\end{array}$ & $\begin{array}{l}\text { Identificar se o aluno possui hábito } \\
\text { de ingerir bebida alcóolica com a } \\
\text { finalidade de identificar o hábito } \\
\text { de vida }\end{array}$ & $\begin{array}{l}\text { Sim } \\
\text { Não }\end{array}$ \\
\hline $\begin{array}{l}\text { Quais são } \\
\text { os hábitos } \\
\text { alimentares }\end{array}$ & $\begin{array}{l}\text { Traçar o perfil dos hábitos } \\
\text { alimentares dos universitários }\end{array}$ & $\begin{array}{l}\text { Preocupa muito com a } \\
\text { qualidade dos alimentos } \\
\text { Preocupa um pouco com a } \\
\text { qualidade } \\
\text { Não se preocupa }\end{array}$ \\
\hline $\begin{array}{l}\text { Onde costuma } \\
\text { realizar as } \\
\text { refeições }\end{array}$ & $\begin{array}{l}\text { Identificar se o aluno possui costume } \\
\text { de realizar as refeições em casa ou } \\
\text { na rua }\end{array}$ & $\begin{array}{l}\text { Rua (restaurantes, } \\
\text { lanchonetes) } \\
\text { Casa (ou leva de casa) }\end{array}$ \\
\hline Doenças & $\begin{array}{l}\text { Identificar se o universitário possui } \\
\text { doenças advindas da alimentação } \\
\text { inadequada }\end{array}$ & $\begin{array}{l}\text { Diabetes } \\
\text { Cardiovascular } \\
\text { Hormonais } \\
\text { Não }\end{array}$ \\
\hline $\begin{array}{l}\text { Atividade física } \\
\text { no curso }\end{array}$ & $\begin{array}{l}\text { Identificar se o aluno se inscreveria } \\
\text { caso o curso oferecesse atividade } \\
\text { física como atividade complementar }\end{array}$ & $\begin{array}{l}\text { Sim } \\
\text { Não }\end{array}$ \\
\hline Locomoção & $\begin{array}{l}\text { Identificar como o aluno se locomove } \\
\text { até a universidade }\end{array}$ & $\begin{array}{l}\text { Carro/ moto } \\
\text { Transporte público } \\
\text { Bicicleta } \\
\text { A pé }\end{array}$ \\
\hline Bolsa atleta & $\begin{array}{l}\text { Identificar se o universitário se } \\
\text { interessa e acharia relevante se a } \\
\text { universidade oferecesse bolsa atleta }\end{array}$ & $\begin{array}{l}\text { Sim } \\
\text { Não }\end{array}$ \\
\hline $\begin{array}{l}\text { IMC como um } \\
\text { interferente na } \\
\text { qualidade de } \\
\text { vida }\end{array}$ & $\begin{array}{l}\text { Identificar se o universitário } \\
\text { acredita que o IMC interfere em sua } \\
\text { produtividade e na qualidade de vida }\end{array}$ & Resposta aberta \\
\hline
\end{tabular}

Fonte: Elaborado pelos autores (2019).

\section{Resultados e discussão}

O perfil dos respondentes $(n=75)$ da pesquisa possui a seguinte característica: Feminino (61,3\%), de 18 a 25 anos (70,7\%), nos $8^{\circ}$ e $9^{\circ}$ períodos $(18,7 \%)$ e trabalha como estagiário ou alta gerência (34,7\%), conforme podemos observar na Tabela 1 . 
Tabela 1. Perfil dos respondentes

\begin{tabular}{|c|c|c|c|}
\hline Pergunta & Tiро & Quantidade & $\%$ \\
\hline Gênero & $\begin{array}{l}\text { Feminino } \\
\text { Masculino } \\
\text { Outro }\end{array}$ & $\begin{array}{c}46 \\
29 \\
0\end{array}$ & $\begin{array}{c}61,3 \% \\
38,7 \% \\
0 \%\end{array}$ \\
\hline Faixa etária & $\begin{array}{l}18 \text { a } 25 \text { anos } \\
26 \text { a } 30 \text { anos } \\
31 \text { a } 35 \text { anos } \\
36 \text { a } 40 \text { anos } \\
41 \text { a } 45 \text { anos } \\
\text { Acima de } 46 \text { anos }\end{array}$ & $\begin{array}{l}53 \\
18 \\
2 \\
0 \\
2 \\
0\end{array}$ & $\begin{array}{c}70,7 \% \\
24,0 \% \\
2,7 \% \\
0 \% \\
2,7 \% \\
0 \%\end{array}$ \\
\hline Período & $\begin{array}{l}1^{\circ} \text { Semestre } \\
2^{\circ} \text { Semestre } \\
3^{\circ} \text { Semestre } \\
4^{\circ} \text { Semestre } \\
5^{\circ} \text { Semestre } \\
6^{\circ} \text { Semestre } \\
7^{\circ} \text { Semestre } \\
8^{\circ} \text { Semestre } \\
9^{\circ} \text { Semestre }\end{array}$ & $\begin{array}{c}6 \\
2 \\
9 \\
1 \\
7 \\
6 \\
16 \\
14 \\
14\end{array}$ & \begin{tabular}{c|}
$8,0 \%$ \\
$2,7 \%$ \\
$12,0 \%$ \\
$1,3 \%$ \\
$9,3 \%$ \\
$8,0 \%$ \\
$21,3 \%$ \\
$18,7 \%$ \\
$18,7 \%$
\end{tabular} \\
\hline $\begin{array}{l}\text { Área em que } \\
\text { trabalha }\end{array}$ & $\begin{array}{l}\text { Estagiário (a) } \\
\text { Operacional (colaboradores) } \\
\text { Tática (gerência média) } \\
\text { Estratégica (alta gerência) } \\
\text { Não trabalha }\end{array}$ & $\begin{array}{c}26 \\
1 \\
12 \\
26 \\
10\end{array}$ & $\begin{array}{c}34,7 \% \\
1,3 \% \\
16,0 \% \\
34,7 \% \\
13,3 \%\end{array}$ \\
\hline
\end{tabular}

Fonte: Elaborado pelos autores (2019).

Sobre as questões relacionadas aos hábitos alimentares e nível de atividade física associados à qualidade de vida dos estudantes, podemos observar que $48 \%$ não praticam frequentemente atividades físicas, que $85,3 \%$ não possuem o hábito de fumar, $60 \%$ se preocupam um pouco com a qualidade elou com seus hábitos alimentares, que 57,3\% realizam suas refeições em casa ou levam de casa suas refeições, que 90,7\% não possuem doenças como diabetes, cardiovasculares ou hipertireoidismo e $78,7 \%$ dos respondentes afirmaram que, se no conteúdo programático do curso fossem oferecidas atividades físicas como atividade complementar, realizariam, conforme a Tabela 2. 
Tabela 2. Perfil de Atividades dos respondentes

\begin{tabular}{|c|c|c|c|}
\hline $\begin{array}{l}\text { Frequência que pratica } \\
\text { atividade física }\end{array}$ & $\begin{array}{l}1 \text { a } 2 \text { vezes na semana } \\
3 \text { a } 4 \text { vezes na semana } \\
\text { Mais de } 4 \text { vezes na semana } \\
\text { Não pratica }\end{array}$ & $\begin{array}{l}19 \\
14 \\
6 \\
36\end{array}$ & $\begin{array}{l}25,3 \% \\
18,7 \% \\
8,0 \% \\
48,0 \%\end{array}$ \\
\hline Possui hábito de fumar & $\begin{array}{l}\text { Sim } \\
\text { Não }\end{array}$ & $\begin{array}{l}11 \\
64\end{array}$ & $\begin{array}{l}14,7 \% \\
85,3 \%\end{array}$ \\
\hline $\begin{array}{l}\text { Possui hábito de } \\
\text { ingerir bebida } \\
\text { alcóolica }\end{array}$ & $\begin{array}{l}\text { Sim } \\
\text { Não }\end{array}$ & $\begin{array}{l}38 \\
37\end{array}$ & $\begin{array}{l}50,7 \% \\
49,3 \%\end{array}$ \\
\hline $\begin{array}{l}\text { Quais são os hábitos } \\
\text { alimentares }\end{array}$ & $\begin{array}{l}\text { Preocupa muito com a qualidade } \\
\text { dos alimentos } \\
\text { Preocupa um pouco com a } \\
\text { qualidade } \\
\text { Não se preocupa }\end{array}$ & $\begin{array}{l}14 \\
45 \\
16\end{array}$ & $\begin{array}{l}18,7 \% \\
60,0 \% \\
21,3 \%\end{array}$ \\
\hline Realizar as refeições & $\begin{array}{l}\text { Rua (restaurantes, lanchonetes) } \\
\text { Casa (ou leva de casa) }\end{array}$ & $\begin{array}{l}32 \\
43 \\
\end{array}$ & \begin{tabular}{|l|}
$42,7 \%$ \\
$57,3 \%$ \\
\end{tabular} \\
\hline Possui Doenças & $\begin{array}{l}\text { Cardiovascular } \\
\text { Diabetes } \\
\text { Hormonais } \\
\text { Respiratórias } \\
\text { Não }\end{array}$ & $\begin{array}{l}2 \\
1 \\
3 \\
1 \\
68\end{array}$ & \begin{tabular}{|l|}
$2,7 \%$ \\
$1,3 \%$ \\
$4,0 \%$ \\
$1,3 \%$ \\
$90,7 \%$
\end{tabular} \\
\hline $\begin{array}{l}\text { Atividade física no } \\
\text { curso }\end{array}$ & $\begin{array}{l}\text { Sim } \\
\text { Não }\end{array}$ & $\begin{array}{l}59 \\
16\end{array}$ & $\begin{array}{l}78,7 \% \\
21,3 \%\end{array}$ \\
\hline
\end{tabular}

Fonte: Elaborado pelos autores (2019).

Com relação ao IMC, na Tabela 3 apresentamos os dados individuais de peso e altura que compõem o cálculo do índice.

Tabela 3. Cálculo do IMC e classificação

\begin{tabular}{|c|l|c|c|c|l|}
\hline Aluno & \multicolumn{1}{|c|}{ Sexo } & Peso & Altura & IMC & \multicolumn{1}{|c|}{ Classificação } \\
\hline 1 & Feminino & 65 & 1,64 & 24,17 & Saudável \\
\hline 2 & Feminino & 69 & 1,65 & 25,34 & Sobrepeso \\
\hline 3 & Feminino & 95 & 1,68 & 33,66 & Obesidade Grau I \\
\hline 4 & Masculino & 73 & 1,71 & 24,96 & Saudável \\
\hline 5 & Masculino & 87 & 1,83 & 25,98 & Sobrepeso \\
\hline 6 & Feminino & 80 & 1,65 & 29,38 & Sobrepeso \\
\hline 7 & Masculino & 90 & 1,77 & 28,73 & Sobrepeso \\
\hline 8 & Masculino & 78 & 1,78 & 24,62 & Saudável \\
\hline 9 & Masculino & 77 & 1,79 & 24,03 & Saudável \\
\hline 10 & Feminino & 68 & 1,59 & 26,90 & Sobrepeso \\
\hline
\end{tabular}


Tabela 3. Continuação

\begin{tabular}{|c|c|c|c|c|c|}
\hline Aluno & Sexo & Peso & Altura & IMC & Classificação \\
\hline 11 & Feminino & 60 & 1,65 & 22,04 & Saudável \\
\hline 12 & Feminino & 49 & 1,67 & 17,57 & Magreza leve \\
\hline 13 & Feminino & 65 & 1,76 & 20,98 & Saudável \\
\hline 14 & Feminino & 75 & 1,66 & 27,22 & Sobrepeso \\
\hline 15 & Feminino & 56 & 1,53 & 23,92 & Saudável \\
\hline 16 & Feminino & 48 & 1,58 & 19,23 & Saudável \\
\hline 17 & Masculino & 63 & 1,75 & 20,57 & Saudável \\
\hline 18 & Feminino & 80 & 1,81 & 24,42 & Saudável \\
\hline 19 & Feminino & 47 & 1,5 & 20,89 & Saudável \\
\hline 20 & Feminino & 55 & 1,59 & 21,76 & Saudável \\
\hline 21 & Feminino & 61 & 1,64 & 22,68 & Saudável \\
\hline 22 & Feminino & 75 & 1,51 & 32,89 & Obesidade Grau I \\
\hline 23 & Masculino & 79 & 1,75 & 25,80 & Sobrepeso \\
\hline 24 & Masculino & 64 & 1,7 & 22,15 & Saudável \\
\hline 25 & Feminino & 54 & 1,58 & 21,63 & Saudável \\
\hline 26 & Feminino & 59 & 1,62 & 22,48 & Saudável \\
\hline 27 & Feminino & 90 & 1,6 & 35,16 & Obesidade Grau II \\
\hline 28 & Feminino & 59 & 1,64 & 21,94 & Saudável \\
\hline 29 & Feminino & 48 & 1,66 & 17,42 & Magreza leve \\
\hline 30 & Masculino & 84 & 1,85 & 24,54 & Saudável \\
\hline 31 & Feminino & 55 & 1,6 & 21,48 & Saudável \\
\hline 32 & Feminino & 51 & 1,56 & 20,96 & Saudável \\
\hline 33 & Feminino & 61 & 1,66 & 22,14 & Saudável \\
\hline 34 & Feminino & 62 & 1,68 & 21,97 & Saudável \\
\hline 35 & Feminino & 62 & 1,67 & 22,23 & Saudável \\
\hline 36 & Masculino & 89 & 1,79 & 27,78 & Sobrepeso \\
\hline 37 & Feminino & 85 & 1,67 & 30,48 & Obesidade Grau I \\
\hline 38 & Masculino & 65 & 1,7 & 22,49 & Saudável \\
\hline 39 & Masculino & 70 & 1,74 & 23,12 & Saudável \\
\hline 40 & Feminino & 60 & 1,7 & 20,76 & Saudável \\
\hline 41 & Feminino & 60 & 1,59 & 23,73 & Saudável \\
\hline 42 & Feminino & 61 & 1,62 & 23,24 & Saudável \\
\hline 43 & Masculino & 76 & 1,81 & 23,20 & Saudável \\
\hline 44 & Feminino & 54 & 1,73 & 18,04 & Magreza leve \\
\hline 45 & Feminino & 60 & 1,65 & 22,04 & Saudável \\
\hline 46 & Masculino & 80 & 1,7 & 27,68 & Sobrepeso \\
\hline 47 & Masculino & 90 & 1,8 & 27,78 & Sobrepeso \\
\hline 48 & Feminino & 54 & 1,64 & 20,08 & Saudável \\
\hline 49 & Feminino & 87 & 1,6 & 33,98 & Obesidade Grau I \\
\hline 50 & Feminino & 57 & 1,65 & 20,94 & Saudável \\
\hline 51 & Masculino & 62 & 1,71 & 21,20 & Saudável \\
\hline
\end{tabular}


Tabela 3. Continuação

\begin{tabular}{|c|l|c|c|c|l|}
\hline Aluno & \multicolumn{1}{|c|}{ Sexo } & Peso & Altura & IMC & \multicolumn{1}{|c|}{ Classificação } \\
\hline 52 & Masculino & 80 & 1,83 & 23,89 & Saudável \\
\hline 53 & Masculino & 83 & 1,83 & 24,78 & Saudável \\
\hline 54 & Feminino & 99 & 1,71 & 33,86 & Obesidade Grau I \\
\hline 55 & Feminino & 84 & 1,66 & 30,48 & Obesidade Grau I \\
\hline 56 & Masculino & 67 & 1,81 & 20,45 & Saudável \\
\hline 57 & Masculino & 56 & 1,82 & 16,91 & Magreza moderada \\
\hline 58 & Feminino & 57 & 1,66 & 20,69 & Saudável \\
\hline 59 & Feminino & 64 & 1,62 & 24,39 & Saudável \\
\hline 60 & Feminino & 57 & 1,63 & 21,45 & Saudável \\
\hline 61 & Masculino & 69 & 1,7 & 23,88 & Saudável \\
\hline 62 & Masculino & 64 & 1,76 & 20,66 & Saudável \\
\hline 63 & Feminino & 70 & 1,5 & 31,11 & Obesidade Grau I \\
\hline 64 & Feminino & 68 & 1,58 & 27,24 & Sobrepeso \\
\hline 65 & Feminino & 67 & 1,67 & 24,02 & Saudável \\
\hline 66 & Masculino & 115 & 1,83 & 34,34 & Obesidade Grau I \\
\hline 67 & Masculino & 107 & 1,76 & 34,54 & Obesidade Grau I \\
\hline 68 & Masculino & 120 & 1,9 & 33,24 & Obesidade Grau I \\
\hline 69 & Masculino & 74 & 1,7 & 25,61 & Sobrepeso \\
\hline 70 & Feminino & 47 & 1,56 & 19,31 & Saudável \\
\hline 71 & Masculino & 74 & 1,77 & 23,62 & Saudável \\
\hline 72 & Masculino & 75 & 1,73 & 25,06 & Sobrepeso \\
\hline 73 & Masculino & 85 & 1,75 & 27,76 & Sobrepeso \\
\hline 74 & Feminino & 70 & 1,66 & 25,40 & Sobrepeso \\
\hline 75 & Feminino & 70 & 1,67 & 25,10 & Sobrepeso \\
\hline
\end{tabular}

Fonte: Elaborado pelos autores (2019).

Com relação ao IMC por gênero, faixa etária e área de trabalho, na Tabela 4 apresentamos a classificação agrupada do IMC conforme a "Magreza grave" (Mg); "Magreza moderada" (Mm); "Magreza leve" (MI); "Saudável" (Sd); "Sobrepeso" (Sp); "Obesidade grau I" (OGI); "Obesidade grau II" (OGII); e "Obesidade grau III" (OGIII). Podemos observar que em relação ao gênero, $60 \%$ das mulheres estão saudáveis contra 55,2\% dos homens. Já com relação à faixa etária, 39,4\% dos alunos entre 18 e 25 anos estão saudáveis. Quanto ao trabalho, 22,4\% dos colaboradores operacionais estão saudáveis.

Os resultados apresentados acima demonstram problemas de qualidade de vida dos estudantes de Administração da FEA-PUC quando observamos que $55,8 \%$ não praticam atividades físicas, $41,9 \%$ têm o 
hábito de ingerir bebida alcoólica e 25,6\% não se preocupam com os hábitos alimentares (Tabela 2).

Tabela 4. Classificação (IMC) por gênero, faixa etária e área de trabalho

\begin{tabular}{|c|c|c|c|c|c|c|c|c|}
\hline \multirow{2}{*}{ Variáveis } & \multicolumn{8}{|c|}{ Classificação (IMC) } \\
\hline & Mg & Mm & MI & Sd & Sp & OG-I & OG-II & OG-III \\
\hline \multicolumn{9}{|l|}{ Gênero } \\
\hline Feminino & $0,0 \%$ & $0,0 \%$ & $6,5 \%$ & $60,9 \%$ & $15,2 \%$ & $15,2 \%$ & $2,2 \%$ & $0,0 \%$ \\
\hline Masculino & $0,0 \%$ & $3,4 \%$ & $0,0 \%$ & $55,2 \%$ & $31,0 \%$ & $10,3 \%$ & $0,0 \%$ & $0,0 \%$ \\
\hline \multicolumn{9}{|l|}{ Faixa etária } \\
\hline 18 a 25 anos & $0,0 \%$ & $1,1 \%$ & $2,9 \%$ & $39,4 \%$ & $14,7 \%$ & $9,7 \%$ & $0,0 \%$ & $0,0 \%$ \\
\hline 26 a 30 anos & $0,0 \%$ & $0,0 \%$ & $0,0 \%$ & $11,3 \%$ & $6,2 \%$ & $8,1 \%$ & $1,7 \%$ & $0,0 \%$ \\
\hline 31 a 35 anos & $0,0 \%$ & $0,0 \%$ & $0,0 \%$ & $2,3 \%$ & $0,0 \%$ & $0,0 \%$ & $0,0 \%$ & $0,0 \%$ \\
\hline 41 a 45 anos & $0,0 \%$ & $0,0 \%$ & $0,0 \%$ & $0,0 \%$ & $2,8 \%$ & $0,0 \%$ & $0,0 \%$ & $0,0 \%$ \\
\hline Acima de 46 anos & $0,0 \%$ & $0,0 \%$ & $0,0 \%$ & $0,0 \%$ & $0,0 \%$ & $0,0 \%$ & $0,0 \%$ & $0,0 \%$ \\
\hline \multicolumn{9}{|c|}{ Área em que trabalha } \\
\hline Estagiário (a) & $0,0 \%$ & $0,0 \%$ & $2,0 \%$ & $11,4 \%$ & $11,9 \%$ & $10,0 \%$ & $1,7 \%$ & $0,0 \%$ \\
\hline $\begin{array}{l}\text { Estratégica } \\
\text { (alta gerência) }\end{array}$ & $0,0 \%$ & $0,0 \%$ & $0,0 \%$ & $1,4 \%$ & $0,0 \%$ & $0,0 \%$ & $0,0 \%$ & $0,0 \%$ \\
\hline Não trabalho & $0,0 \%$ & $1,1 \%$ & $0,9 \%$ & $10,7 \%$ & $1,4 \%$ & $0,0 \%$ & $0,0 \%$ & $0,0 \%$ \\
\hline $\begin{array}{l}\text { Operacional } \\
\text { (colaboradores) }\end{array}$ & $0,0 \%$ & $0,0 \%$ & $0,0 \%$ & $22,4 \%$ & $8,7 \%$ & $1,3 \%$ & $0,0 \%$ & $0,0 \%$ \\
\hline $\begin{array}{l}\text { Tática } \\
\text { (gerência média) }\end{array}$ & $0,0 \%$ & $0,0 \%$ & $0,0 \%$ & $7,0 \%$ & $1,6 \%$ & $6,5 \%$ & $0,0 \%$ & $0,0 \%$ \\
\hline \multicolumn{9}{|c|}{$\begin{array}{l}\mathrm{n}=75, \mathrm{Mg}=\text { Magreza grave }, \mathrm{Mm}=\text { Magreza moderada, } \mathrm{Ml}=\text { Magreza leve, } \\
\mathrm{Sd}=\text { Saudável, }\end{array}$} \\
\hline $\begin{array}{l}\text { Sp }=\text { Sobrepeso }, \mathrm{O} \\
\text { OGIII = Obesidade }\end{array}$ & besi & ade $g$ & , O & $\mathrm{Ob}$ & $\operatorname{ad}$ & & & \\
\hline
\end{tabular}

Fonte: Elaborado pelos autores (2019).

Quando perguntado aos alunos da FEA se acreditam que o IMC interfere em sua produtividade e na qualidade de vida (Tabela 5), 64\% dos alunos acreditam que sim, mas as análises de seus hábitos indicam que alunos têm informação sobre os problemas de saúde relacionados ao sobrepeso, porém continuam com hábitos prejudiciais à saúde e à qualidade de vida, conforme apresentado na Tabela 2. 
Tabela 5. Questão aberta

\begin{tabular}{|l|c|c|}
\hline \multicolumn{1}{|c|}{ Resposta } & Quantidade & $\%$ \\
\hline Sim & 48 & $64,0 \%$ \\
\hline Não & 24 & $32,0 \%$ \\
\hline Nunca pensei nisso & 1 & $1,3 \%$ \\
\hline Talvez & 1 & $1,3 \%$ \\
\hline Não sei & 1 & $1,3 \%$ \\
\hline Total Geral & $\mathbf{7 5}$ & $\mathbf{1 0 0 \%}$ \\
\hline
\end{tabular}

Fonte: Elaborado pelos autores (2019).

Destacamos a seguir algumas falas de alunos que escolheram o "sim" como resposta:

Sim. Hábitos saudáveis como praticar atividade física regularmente, ter uma alimentação balanceada e até mesmo um sono de qualidade estão ligados ao nível de produtividade acadêmica e profissional (Respondente 5).

Acredito que sim. Sou um ex-sedentário e tinha um IMC acima de 30 há alguns anos, época em que me sentia extremamente cansado e tinha dificuldades de concentração. Hoje me sinto muito mais vivo, mais ativo e apto para ter bom rendimento em todos os campos da vida. Outra coisa que notei, falando de um processo físico em si, é a capacidade de formular pensamentos em situações de estresse. Quando fazia apresentações antes, qualquer coisa fora do previsto tirava minha concentração e era comum eu me perder no assunto. Hoje não vivencio mais estas coisas e consigo responder calmamente aos estímulos externos (Respondente 6).

Com toda certeza, pois o desempenho do indivíduo depende do que ele consume, e se ele se alimenta mal ou não come muito bem, cai a sua produtividade porque desencadeia outras doenças que podem afetar (Respondente 11).

Sim, acredito muito na relação direta, mas infelizmente hoje os jovens não possuem tanto tempo para praticar esportes, ainda 
mais se morar muito longe da faculdade, como é o meu caso. Duas horas no caminho poderiam ser destinadas a manter uma qualidade de vida maior, mas isso não é possível (Respondente 26).

Sim, ele que mede a nossa classificação de Magreza a Obesidade Grave. Isso implica muito no nosso modo de viver, como nossa autoestima, e até mesmo nas aparições de doenças, como a diabetes e doenças cardiovasculares (respondente 67).

Das falas dos alunos que destacaram o "não" como resposta, selecionamos abaixo as mais importantes:

Não, não gosto de associar essa forma de medição ao meu bemestar, porque ela se limita à relação peso e altura, sendo que o peso não necessariamente está associado a uma má qualidade de vida (Respondente 7).

Não necessariamente, acredito que esse índice aponta mais para o estado de saúde e o que fazer para melhorar. A produtividade acadêmica é influenciada por outros fatores, que não se resumem apenas ao IMC (Respondente 41).

Não, o IMC é um método BEM ultrapassado e pouco preciso para "medir" ou classificar a saúde da pessoa. Acredito que uma alimentação saudável, prática de exercícios, horas de sono adequadas interferem totalmente na qualidade de vida e produtividade acadêmica (Respondente 45).

Segundo pesquisa realizada na Faculdade de Economia e Administração da Universidade de São Paulo, os alunos de graduação em Administração têm se preocupado cada vez mais em complementar a formação acadêmica e adquirir experiência profissional (CASTRO et al., 2007).

A obesidade pode ser definida, de forma simplificada, como uma doença caracterizada pelo acúmulo excessivo de gordura corporal, 
sendo consequência de balanço energético positivo e que acarreta repercussões à saúde, com perda importante não só na qualidade como na quantidade de vida (WORLD HEALTH ORGANIZATION, 2000).

A redução do nível de atividade física e sua relação com a ascensão na prevalência da obesidade está ligada às mudanças na distribuição das ocupações por setor (por exemplo, da agricultura para a indústria) e nos processos de trabalho com redução do esforço físico ocupacional (MENDONÇA; ANJOS, 2004).

Um fato extremamente preocupante são as elevadas taxas de sedentarismo e excesso de peso na população, principalmente entre crianças e adolescentes, que se alimentam de forma demasiada e inadequada, são expostos à sedução do tabagismo, fazem uso excessivo da mídia e internet, entre outras formas de atividade eletrônica, estimulando assim a inatividade física e adquirindo possíveis fatores de risco para doenças cardiovasculares (GUIMARÃES, 2002).

Segundo publicação do Atlas do Esporte no Brasil (HATZIDAKIS, 2006), o esporte universitário pode ser definido, em princípio, como uma forma de esporte institucional que oferece atividade física para os membros da universidade/faculdade. É impossível negar a contribuição do desporto acadêmico para a aproximação do ser humano; de seus relacionamentos; do incentivo ao coleguismo, ao espírito de coletivismo e ao incentivo à formação de novas liderança (HATZIDAKIS , 2006).

O esporte moderno, com sua atual organização estrutural, categorias e uniformização de regras, está intimamente ligado à universidade. Na verdade, ele nasceu nas universidades e escolas públicas inglesas no século XIX, quando práticas populares foram sistematizadas para um melhor controle do tempo livre dos adolescentes das classes dominantes e ascendentes (ELIAS, 1992; FOUCAULT, 2007).

Os jogos esportivos coletivos têm se manifestado significativamente no cenário nacional, sendo que cabe à Confederação Brasileira do Desporto Universitário (CBDU) organizar as competições nacionais e representar o Brasil junto à Federação Internacional de Esporte Universitário, a FISU (CONFEDERAÇÃO BRASILEIRA DO DESPORTO UNIVERSITÁRIO, 2018). 


\section{Considerações finais}

A qualidade de vida é um assunto discutido cada vez mais nos dias de hoje, visto que jovens adultos, adultos e idosos buscam constantemente obter uma boa saúde física e mental, preocupando-se com os hábitos saudáveis.

Não podemos deixar de ressaltar que a atividade física e a alimentação saudável são fatores que se relacionam diretamente com a qualidade de vida, uma vez que atuam diretamente na prevenção das doenças crônicas não transmissíveis.

Conforme identificado na pesquisa, a maioria dos alunos acredita que o IMC interfere em sua produtividade e em sua qualidade de vida, embora as análises de seus hábitos identifiquem problemas de saúde relacionados ao sobrepeso e hábitos não saudáveis, como alimentação inadequada, etilismo e tabagismo.

A universidade tem papel importante uma vez que a maioria dos alunos afirmou que, se no conteúdo programático do curso fosse oferecida atividade física como atividade complementar, a realizaria.

O presente estudo encontrou limitações em relação à quantidade de alunos que responderam o questionário, uma vez que foram encaminhados apenas para os alunos do curso de Administração da FEA-PUC, já que os demais alunos não aceitam receber e-mail com tal solicitação que não seja do próprio curso. Outro motivo seria a disponibilidade do aluno em responder tal questionário no período em que foi encaminhado.

Novos estudos devem ser realizados a fim de complementar esta pesquisa, como a possibilidade de inserção de universidades em período integral - sobre isso, temos como exemplos grandes atletas mundiais norte-americanos, que estavam inseridos e sempre incentivados ao esporte no período de sua formação, desde a fase escolar até a universidade. Outro estudo que agregaria a esta pesquisa seria sobre a necessidade dos jovens ingressarem cedo no mercado de trabalho, enquanto ainda cursam a universidade, e por esse motivo não dispõem de tempo hábil para a prática de atividades físicas. 


\section{Bibliografia}

ALBUQUERQUE, Lindolfo Galvão de; FRANÇA, Ana Cristina Limongi. Estratégia de recursos humanos e gestão da qualidade de vida no trabalho: o stress e a expansão do conceito de qualidade total. Revista de Administração, São Paulo, v. 33, n. 2, p. 40-51, abr./ jun. 1998.

BARROS, Marina Foresti; LIMONGI-FRANÇA, Ana Cristina. O Estagiário de administração nas organizações brasileiras: um estudo comparativo entre a visão do aluno e das empresas. In: Seminários em Administração, 7., 2004, São Paulo. Anais [...]. São Paulo: FEA-USP, 2004.

CASTRO, Luiz Alberto Marcondes Homen de Mello et al. Expectativas e Satisfação dos Alunos em Graduação em Administração da FEA-USP/SP em relação aos estágios. Revista de Gestão Usp, São Paulo, v. 14, edição especial, p. 61-76, jan. 2007. Disponível em: https://bit.ly/35JdLfS. Acesso em: 7 set. 2018.

CONFEDERAÇÃO BRASILEIRA DO DESPORTO UNIVERSITÁRIO. Sobre a CBDU, 2020. Disponível em: https://www.cbdu.org.br/institucional/. Acesso em: 8 set. 2018.

COQUEIRO, Raildo da Silva et al. Insatisfação com a imagem corporal: avaliação comparativa da associação com estado nutricional em universitários. Rev. psiquiatr. Rio Gd. Sul, Porto Alegre, v. 30, n. 1, 2008. Disponível em: https://bit.ly/3c65Qul. Acesso em: 26 maio 2018. ELIAS, Norbert. A gênese do desporto: um problema sociológico. In: ELIAS, Norbert; DUNNING, Eric (Orgs.). A busca da excitação. Tradução de M.M.A. e Silva. Lisboa: Difel, 1992, p.188-220.

FEITOSA, Eline Prado Santos et al. Hábitos alimentares de estudantes de uma universidade pública no Nordeste, Brasil. Alim. Nutri., Araraquara, v. 21, n. 2, p. 225-230, abr./jun. 2010. Disponível em: https://bit.ly/35DvWUq. Acesso em: 25 maio 2018.

FONTES, Ana Cláudia Dias; VIANNA, Rodrigo Pinheiro Toledo. Prevalência e fatores associados ao baixo nível de atividade física entre estudantes universitários de uma universidade pública da região Nordeste Brasil. Rev. bras. epidemiol., São Paulo, v. 12, n. 1, p. 20-29, mar. 2009. Disponível em: https://bit.ly/3iE7qWK. Acesso em: 16 st. 2020. 
FOUCAULT, Michel. Microfísica do poder. 23. ed. Rio de Janeiro: Graal, 2007.

GARDNER, Rick M. Methodological issues in assessment of the perceptual component of body image disturbance. Br J Psychol, Londres, v. 87, n. 2, p. 327-37, 1996.

GASPAROTTO, Guilherme da Silva. Associação entre o nível de atividade física e fatores de risco cardiovascular em universitários da UFPR. 2012. Dissertação (Mestrado em Educação Física) Universidade Federal do Paraná, Curitiba, 2012. Disponível em: https://bit.ly/33Czq6S. Acesso em: 18 maio 2018.

GUIMARÃES, AC. Prevenção de Doenças Cardiovasculares no século 21.

Rev. Hipertensão, São Paulo, v. 5, n. 1, p. 103-106, jun. 2002.

HATZIDAKIS, Georgios. Esporte Universitário. In: DA COSTA, Lamartine (org.). Atlas do Esporte no Brasil. Rio de Janeiro: Confef, 2006. Disponível em: https://bit.ly/2E816If. Acesso em: 8 set. 2018.

KAKESHITA, Idalina Shiraishi; ALMEIDA, Sebastião de Sousa. Relação entre índice de massa corporal e a percepção da auto-imagem em universitários. Rev. Saúde Pública, São Paulo, v. 40, n. 3, p. 497-504, 2006. Disponível em: https://bit.ly/2ZK6Nn6. Acesso em: 26 maio 2018.

KAWAKAME, Patrícia Moita Garcia; MIYADAHIRA, Ana Maria Kazue. Qualidade de vida de estudantes de graduação em enfermagem. Rev. esc. enferm. USP, São Paulo, v. 39, n. 2, p. 164-172, 2005. Disponível em: https://bit.ly/33z3P6e. Acesso em: 25 maio 2018. MARCONDELLI, Priscilla; COSTA, Teresa Helena Macedo da; SCHMITZ, Bethsáida de Abreu Soares. Nível de atividade física e hábitos alimentares de universitários do $3^{\circ}$ ao $5^{\circ}$ semestres da área da saúde. Rev. Nutr., Campinas, v. 21, n. 1, p. 39-47, 2008. Disponível em: https://bit.ly/3iCalPX. Acesso em: 25 maio 2018.

MEDEIROS, Ingrid Maria Paes Jorge; ARTIOLI, Dérrick Patrick; OLIVEIRA, Beatriz Berenchtein Bento de. Risco de desenvolvimento de diabetes tipo II em frequentadores de um centro universitário. Revista Varia Scientia - Ciências da Saúde, Cascavel, v. 3, n. 2, 2017. Disponível em: https://bit.ly/3hyidQV. Acesso em: 8 set. 2018.

MENDONÇA, Cristina Pinheiro; ANJOS, Luiz Antonio dos. Aspectos das práticas alimentares e da atividade física como determinantes do crescimento do sobrepeso/obesidade no Brasil. Cad. Saúde 
Pública, Rio de Janeiro, v. 20, n. 3, p. 698-709, 2004. Disponível em: https://bit.ly/2E8cBzp. Acesso em: 7 set. 2008.

NAVARRO, Anderson Marliere; MARCHINI, Julio Sérgio. Uso de medidas antropométricas para estimar gordura corporal em adultos. Nutrire Rev. Soc. Bras. Aliment. Nutr., São Paulo, v. 19/20, p. 31-47, 2000.

PERISSINOTTO, Egle et al. Anthropometric measurements in the elderly: age and gender differences. Br J Nutr., n. 87, v.2, p. 177-86, 2002.

PITANGA, Francisco José Gondim; LESSA, Ines. Prevalência e fatores associados ao sedentarismo no lazer em adultos. Cad. Saúde Pública, Rio de Janeiro, v. 21, n. 3, p. 870-877, 2005. Disponível em: https://bit.ly/32yBkGq. Acesso em: 16 set. 2020.

RODRIGUES, Elizângela Sofia Ribeiro; CHEIK, Nadia Carla; MAYER, Anamaria Fleig. Nível de atividade física e tabagismo em universitários. Revista de Saúde Pública, São Paulo, v.42, n.4, 2008. Disponível em: https://bit.ly/3kuLObf. Acesso em: 25 maio 2018.

SURVEYMONKEY. Calculadora do Tamanho da Amostra, 2018. Descubra se você tem respondentes suficientes para sua pesquisa. Disponível em: https://bit.ly/3mpK9Ky. Acesso em: 16 jul. 2018.

WAGNER, Gabriela Arantes; ANDRADE, Arthur Guerra de. Uso de álcool, tabaco e outras drogas entre estudantes universitários brasileiros. Revista de Psiquiatria Clínica, São Paulo, v. 35, n. supl. 1, p. 48-54, 2008. Disponível em: https://bit.ly/32zUzPK. Acesso em: 26 maio 2018. WHOOOL GROUP. Programme on Mental Health Division of Mental Health and Prevention of Substance Abuse. Genebra: World Health Organization, 1997. Disponível em: https://bit.ly/2FGNtA3. Acesso em: 24 março 2018.

WORLD HEALTH ORGANIZATION. Obesity: preventing and managing the global epidemic. Genebra: WHO, 2000. 



\title{
Gestão de marcas de luxo na era digital: redes sociais
}

\author{
Cassia Almeida de Barros \\ Agustin Perez Rodrigues
}

\begin{abstract}
Resumo
A pesquisa destaca a influência das redes sociais na gestão de marcas de luxo e em seus consumidores com intuito de compreender as estratégias tomadas pelas marcas para driblar os desafios das mídias sociais com base no comportamento do consumidor. Foi utilizado o método de pesquisa qualitativa, de caráter exploratório, com orientação analítico-descritiva, mediante entrevistas semiestruturadas com questões em aberto, por meio digital, para efeito comparativo entre teoria e o funcionamento do mercado propriamente dito. Assim, podemos agregar valor para a comunidade acadêmica e para o mercado de luxo em geral, acompanhando a tendência de crescimento do setor. Ao longo da pesquisa, foi possível entender o comportamento do consumidor de luxo nas redes sociais, canalizando esse perfil para definições de estratégias para comunicação de marca e de relacionamento com o cliente e a sociedade por meio das redes sociais, que se transformaram em uma ferramenta poderosa no século XXI. Os dados recolhidos mostram que a gestão de marcas com foco nas redes sociais se tornou indispensável para a comunicação de marca e de relacionamento direto com o consumidor, transformando engajamento em fidelização, rentabilidade e visibilidade de marca.
\end{abstract}

Palavras-chaves: Gestão de marcas. Luxo. Redes sociais. 


\section{INTRODUÇÃO}

A ideia do que é luxo e o modo como ele é inserido em nossa sociedade está presente há muitos séculos. Entretanto, o luxo evoluiu junto com a sociedade e hoje não é apenas uma forma de diferenciação, mas também um estilo de vida.

Para manter viva toda a história e o brilho por trás da exclusividade, as marcas de alto padrão sempre foram referência em fazer uma ótima gestão de marca, estando sempre a frente das tendências de mercado. Mas com a globalização trazendo novos modos de consumo e comportamento dos consumidores, o relacionamento com o cliente mudou, e as empresas que antes ditavam as regras dessa relação estão se adaptando às reviravoltas do mercado.

Nesse novo contexto, as redes sociais estão diretamente ligadas à estratégia da gestão de marcas como fator competitivo. As redes sociais se tornaram bem mais que um local para socializar e ter amigos, hoje são um local de expressão, onde você se coloca verdadeiramente e se expõe, mostrando a que veio.

Este trabalho busca compreender como o mercado de luxo formula suas estratégias e se apropria das novas relações com o consumidor e as redes sociais, e como isso influencia a necessidade de engajar o cliente. É imprescindível entender esses novos desafios da atualidade e estar preparado para vencê-los, principalmente em um mercado que está em constante crescimento como o segmento de luxo. No ano de 2016, o setor gerou 212 bilhões de dólares em vendas, com crescimento de $6,8 \%$, especialmente em países como Brasil e China (OS PODEROSOS [...], 2019).

Por isso, este trabalho científico tem como objetivo identificar como o mercado de luxo está se integrando à nova modalidade de consumo e de estilo de vida de seus clientes, principalmente quanto ao uso de redes sociais e seu impacto para a gestão da marca.

O trabalho será dividido em quatro capítulos, sendo que o primeiro trará os procedimentos metodológicos. O segundo, todos os conceitos referentes ao tema, como marca e gestão de marcas, a diferença entre gestão de uma marca tradicional e de uma marca de luxo, o que é luxo e suas características e o que são as redes sociais. 
O terceiro capítulo irá abordar o segmento de luxo e as redes sociais, abrangendo informações da movimentação desse mercado, o comportamento do consumidor nas redes sociais e como as redes sociais estão impactando as marcas. O último capítulo traz os resultados que foram pesquisados, analisados e levaram a uma consideração final, tanto da parte teórica, quanto da parte prática contando com a entrevista.

\section{Procedimentos metodológicos}

O presente capítulo está estruturado para expor quais procedimentos metodológicos organizados serão utilizados para a busca de respostas ao problema apresentado. Segundo Sakamoto e Silveira (2014), a metodologia aborda as estratégias que são utilizados e como será desenvolvido o estudo para alcançar o objetivo da pesquisa.

\section{Método}

Para garantir a confiabilidade e a qualidade do trabalho científico, é essencial que seja eleito um método. Na definição de Sakamoto e Silveira (2014, p. 31), "o método determina a escolha dos elementos sobre os quais o estudo se apoiará na prática". Como método, foi eleita a abordagem de pesquisa qualitativa, de natureza interpretativa, aplicada, teórica, descritiva, com embasamento em pesquisa bibliográfica onde será buscada a interpretação dos fatos e o enriquecimento científico sobre o objeto definido.

\section{Material}

Para isso, utilizaremos como material artigos científicos (para conhecer outros materiais de estudos sobre o tema), livros, buscaremos na literatura teorias que deem embasamento às conclusões, pesquisas quantitativas e qualitativas de mercado para comprovar 
as afirmações e questionários para conferir ao trabalho informações relevantes e atuais.

\section{Técnica}

Será utilizada no presente estudo a técnica de entrevistas, que "é uma conversa entre o pesquisador e pessoas previamente selecionados. Nessa conversa pretende-se obter dados necessários para melhor compreender a situação problema da pesquisa" (ALBINO; FAQUETI, 2014, p. 3).

O objetivo das entrevistas é recolhermos dados de forma interativa com profissionais da área, podendo conhecer profundamente o mercado e interpretar a opinião do profissional. Também faremos uma pesquisa bibliográfica, que "é a busca por informações e fundamentações a partir de livros e artigos científicos" (ALBINO; FAQUETI, 2014, p. 3).

\section{Procedimento}

Com a finalidade de entender a dinâmica da gestão de marcas de luxo nas mídias sociais e seu relacionamento com o cliente, iremos pesquisar em artigos, livros, pesquisas e entrevistas, separando a cada etapa de revisão as teoria e informações pertinentes para o enriquecimento do trabalho científico. Soma-se a isso um trabalho reflexivo e comparativo entre teorias, entrevistas e pesquisas já realizadas a fim de obter respostas precisas sobre o que ocorre no setor de luxo. O material documentado e as análises serão organizados e relatados no estudo científico que será apresentado.

\section{Conceito}

Marcas e gestão de marcas

A força da marca para empresas começou a surgir no fim da década de 1980, quando em algum momento as empresas perceberam que as 
marcas eram na verdade ativos, patrimônios da empresa, e determinam o desempenho e a estratégia do negócio (AAKER, 2015).

Isso acabou trazendo profundas mudanças para a administração das marcas e como elas eram avaliadas. Quem adotou essa nova visão passou a construção de marca de esforço tático para um fator crucial na estratégia de negócios. Era preciso uma nova estratégia para a retomada do crescimento, como Aaker complementa:

A visão da marca como ativo tinha validade aparente e apoio quantitativo [...], os clientes estavam tomando decisões de compra e avaliando sua experiência de uso com base em elementos de marca que iam além do preço e dos atributos funcionais. (AAKER, 2015, p. 16)

O apoio quantitativo vinha por parte dos dados, que demonstrando todo o valor com ativos que a marca detinha, atraiu diretores e presidentes.

A marca começou a ser analisada em um enfoque econômicofinanceiro, enquanto ativo gerador de valor para seu proprietário, ou seja, a marca representa um capital essencial, apesar de ser tratada como intangível. (SERRALVO, 2008, p. 17)

Isso fez com que cada vez mais empresas aderissem à nova perspectiva e tivessem crescimento contínuo desde então, com resultados extraordinários, o que confirma que a gestão de marcas não é modismo da gestão empresarial.

Para Serralvo (2008), existem dois modelos de gestão de marcas. O modelo clássico é estruturado para resolver problemas de vendas de forma tática e reativa, utilizando o composto de marketing ("4 Ps": preço, praça, produto e promoção). O outro modelo é o de liderança, orientado pela identidade da marca, com foco na estratégia.

O primeiro conceito a ser desmistificado é o de "marca" sendo definido como:

Um nome diferenciado elou símbolo (tal qual como um logotipo, marca registrada, ou desenho da embalagem) destinado a identificar os bens ou serviços de um vendedor ou de um grupo 
de vendedores e a diferenciar esses bens e serviços daqueles concorrentes. (AAKER, 1998, p. 7)

Ou ainda como Serralvo cita Gardner e Levy (1955), que escreveram para a Harvard Business Review sob o título O produto e a marca, a marca passou a ser mais do que apenas um diferenciador de produtos,

é um símbolo complexo que representa várias ideias e diferentes atributos. Além disso, os autores afirmavam que os atributos funcionais dos produtos não seriam suficientes para diferenciar as marcas, pois era necessário desenvolver atributos emocionais ou 'de imagem'. (SERRALVO, 2008, p. 24)

As marcas vendem promessas aos consumidores, o que significa que os clientes não pagam apenas pelo produto e/ou serviço, mas sim pela sua percepção e expectativa - funcional ou emocional. Levando em consideração que o cliente associa a marca ao produto, dessa forma, as marcas passam a ter vida própria na mente do comprador. A marca é mais que um nome ou símbolo, ela se apropria de uma identidade, assumindo uma expressão e representando um estilo de vida.

\section{Brand equity}

De acordo com Aaker (1998, p. 16), Brand equity é "conjunto de ativos e passivos ligados a uma marca, seu nome e símbolo, que se somam ou se subtraem do valor proporcionado por um produto ou serviço para uma empresa e/ou para os consumidores dela".

O Brand equity tem a capacidade de adicionar valor para o consumidor, mas quando qualquer um dos itens acima citados forem alterados ou mal direcionados, isso pode acarretar mudanças nos ativos e passivos da marca. Itens importantes como a lealdade à marca, o conhecimento do nome, a qualidade percebida, associações à marca, outros ativos da marca (como patentes e posicionamento nos canais de distribuição) fortalecem a marca e são seus principais ativos, ainda conforme Aaker. 
O Brand equity, além de adicionar valor à marca e consequentemente para o consumidor, consegue abrir uma margem de segurança para o empresário investir na marca e aumentar seu preço de mercado.

\section{O que é luxo e características do luxo}

A palavra luxo e seu significado foram se formando ao longo dos anos. $\mathrm{Na}$ antiguidade já existia uma definição de luxo, hoje também, e sua definição daqui a 200 anos pode ser diferente da encontrada atualmente. D'Angelo (2006, p.26) confirma quando diz que "as formas de expressão do luxo mudam conforme a evolução das sociedades".

O luxo consegue compreender diversos sentidos. Os materiais e concretos, como bens extremamente caros ou grandes dispêndios, ou, no sentido intangível, envolvendo o supérfluo, a ostentação. Em sua origem, luxus significa ostentação, abundância, refinamento e magnificência, proveniente do latim (D'ANGELO, 2006).

Ainda pode se dizer que "o luxo é uma invenção social, criado pelo homem. É um conjunto de significados conferidos a alguns produtos. É preciso que o bem seja chamado de luxuoso, para que assim seja considerado" (D'ANGELO, 2006, p. 26).

Outra autora explica que "[o] luxo existe em função da distinção social, do conhecimento embutido no consumo e das suas representações" (STREHLAU, 2008, p.23).

O conceito de luxo pode ser aplicado em diversos aspectos da vida: como sinônimo de bens materiais, como adjetivo ("viagem de luxo"), para classificar produtos e/ou serviços, como forma de expressão ("ter tempo para ficar em casa é um luxo para poucos"). Luxo é bem mais que uma palavra e seu significado.

Cada época tem suas características de luxo. Se hoje luxo pode ser tempo, dinheiro, viajar, ficar com a família ou trabalhar com o que se gosta, em outras épocas o luxo poderia ser ter pele para se proteger do frio e carne para comer, ou em outras usar a roupa de determinada cor. O luxo pode ser considerado a "conjugação do prazer com a exclusividade" (D'ANGELO, 2006, p. 27). Compreender as características do luxo e cada sentimento que isso suscita nos 
clientes faz toda a diferença na hora de desenvolver um produto ou serviço, e sem dúvidas faz com que as estratégias de gestão de marcas sejam assertivas.

\section{Gestão de marcas de luxo}

Cercado de desafios, o mercado de luxo enfrenta grandes alterações, tanto no cenário econômico como em relação às mudanças das representações de seus consumidores e novos desejos, ou seja, mudanças na sociedade em geral (a exemplo o uso de pele em roupas e acessórios).

A gestão da marca de luxo é executada de forma a adicionar valor à marca a partir das características de seus produtos e serviços, além de ajudá-la a se propagar amplamente. Isso garante a essência do luxo, pois, se não corresse o risco de ter ganhos a curto prazo, mas ao longo prazo, a marca acaba perdendo valor, chegando a perder o negócio.

Ao olhar para as maiores marcas do mercado de luxo vemos empresas centenárias, como Chanel e Louis Vuitton, e mesmo algumas mais novas, como Versace e Dolce Gabbana. Essas são exemplo de gestão de marca cuja inovação, item muito importante nesse contexto, é muito bem dirigida, assim como pela maior parte de casas de luxo.

Essas ações são planejadas e arquitetadas com um planejamento a longo prazo, garantindo fidelidade e comunicação com seu cliente, que deve ter a percepção da marca. Muitas vezes essa comunicação atinge o intangível, chegando ao emocional, especialmente para as marcas de luxo que, mais do que qualquer setor, são ligadas aos sentimentos do cliente ou dos que querem vir a ser (mais um item gerido pela gestão de marcas e marketing, o desejo).

Esses aspectos ajudam a grife a formar sua estratégia, aliados aos pontos diferenciadores de uma marca de luxo - a história, o estilo único, o nome/imagem -, tomando cuidado para não esquecer seus conceitos e perder a independência, tornando-se irrelevante.

É preciso também oferecer um estilo único de modo que o consumidor a reconheça sem a necessidade de etiquetas, ter uma produção limitada e apresentar programas de comunicação que 
evidenciem o posicionamento ao combinar apelo emocional com excelência de produto (PEREIRA; SCHNEIDER, 2017, p. 96)

Como o branding é o responsável por garantir que todas as situações estejam sob controle, que as estratégias de comunicação estejam alinhadas com os valores, é importante que o diálogo esteja em dia com seu cliente, principalmente no segmento de luxo no qual o cliente está muito próximo. A ideia é garantir a comunicação homogênea em todos os canais, lojas, ações de merchandising, sites, blogs e redes sociais. Por isso, os passos seguidos para a gestão de marcas eficientes são tão importantes, como Aaker explica, "é preciso ter uma análise aprofundada dos segmentos de clientes, concorrentes, tendências de mercado, forças ambientais, pontos fortes e fracos atuais da marca e estratégia de negócios no futuro" (2015, p 37).

Ou seja, é necessário ter um estudo profundo em volta do seu conceito, mesmo que estejamos falando em maior parte de marcas centenárias. O autoconhecimento é imprescindível, toda a empresa precisa estar alinhada com o propósito da marca e com a identidade da marca. Estamos falando de produtos que tem simbolismo, história, e é preciso sentir o que está vendendo.

Mas as táticas escolhidas na gestão de marcas precisam de um estudo ainda mais complexo e muito importante, específico para cada empresa: a análise do perfil do comportamento de seu consumidor. Uma boa gestão de marcas poderá não funcionará se você não conhecer o seu alvo.

\section{Comportamento do consumidor de luxo}

ao estruturar as estratégias de gestão de marcas, um dos critérios mais influentes e poderosos é o consumidor e, claro, seu comportamento. O comportamento do consumidor estuda como e por que os grupos selecionam, compram, consomem e descartam produtos e serviços. Existem diversas vertentes que tentam explicar o ser humano, principalmente nos aspectos de consumo e desejo. Elas podem ser econômicas, psicológicas ou sociais. 
O ser humano tem esses vários pressupostos que influenciam em seu modo de agir, comprar e fazer escolhas de um modo geral. O ser humano é racional, seu comportamento é movido pela razão. O ser humano é emocional, movido por afetos conscientes ou inconscientes. O ser humano é social, conduzido pelas regras do grupo (GIGLIO, 2010).

Como podemos vislumbrar, o mercado de consumidores não pode ser visto de forma homogênea, pois

Existem grupos de consumidores que partilham preferências e características semelhantes entre si e, ao mesmo tempo, diferentes em relação àquelas partilhadas por outros grupos. Neste sentido, faz-se necessário segmentar o mercado para que a empresa consiga atender às demandas de grupos de consumidores específicos e, consequentemente, alcançar maior sucesso mercadológico. (BEANE; ENNIS, 1987 apud MERLO; CERIBELI, 2014, p. 4)

Dessa forma, quando voltamo-nos para o consumidor de produtos e serviços de luxo, nos deparamos com todos esses enfoques, mas com algumas diferenças além dos milhões nos bolsos. Os serviços e produtos do segmento de luxo têm preço superior, bem mais elevados do que o dos bens e serviços intermediários, pois, segundo Passareli, "[o] consumo de luxo deve fazer parte natural daquilo que se chama estilo de vida" (2010, p. 39).

Porém, não estamos falando apenas em altos preço, pois os produtos e/ou serviços de luxo têm como atributos principais qualidade, desempenho, design, durabilidade e exclusividade. Apenas uma pequena parte desse público adquire bens motivada pela elevada precificação.

Recapitulando algumas das vertentes que podem ser usadas para conhecer os comportamentos do consumidor, agora que conhecemos o perfil do cliente de luxo, podemos compreender seu comportamento baseado na racionalidade econômica, social, psicanalítica e cognitiva.

Econômica: na racionalidade econômica, o consumidor visa maximizar seu benefício em detrimento do custo do bem. Essa abordagem não se aplica ao mercado de luxo, segundo Passarelli (2010, p. 40), "em primeiro lugar, porque não almeja desvendar as motivações psicológicas 
do ato de consumir; em segundo, porque não leva em consideração as diferenças individuais, culturais e sociais". Portanto, não podemos reconhecer que todos os consumidores tomem sua decisão de compra baseados exclusivamente na maximização da satisfação.

Social: na teoria social, são enfatizados o comportamento e as relações do indivíduo com o ambiente e suas relações sociais, ou seja, está relacionada diretamente com a identidade social do consumidor. Nessa teoria explica-se o consumo imitativo, entendendo as pressões do grupo sobre o indivíduo como definidoras de comportamentos individuais. Alguns segmentos dentro do mercado de luxo são fortemente ligados a essa dinâmica (PASSARELLI, 2010).

Psicanalítica: essa teoria tem como apoio os ensinamentos de Sigmund Freud (1856-1939) e a teoria psicanalítica, que concebe a mente humana em duas áreas: a consciente e a inconsciente, sendo que esta exerce forte influência sobre a primeira. "Apesar de o ato de consumir estar na esfera do consciente, os verdadeiros motivos encontram-se no inconsciente. Os produtos seriam, então, uma possibilidade, ainda que parcial, de satisfazer os impulsos do inconsciente" (PASSARELLI, 2010, p. 41).

Cabe a área de marketing captar as idealizações do inconsciente de caráter genérico e aproximar o imaginário do inconsciente ao real. Pode não funcionar muito bem com o segmento de luxo.

Cognitiva: a teoria cognitiva explica como o consumo é um processo de tomada de decisão que une consumidor, produto e ambiente. A abordagem diz que a tomada de decisão vem a partir de fatores cognitivos: percepção, motivação, valores, atitudes. Quando usamos essa teoria para o mercado de luxo, devemos ainda levar em consideração a história, renda, grupos de pertencimento, conhecimento, entre outros aspectos, formando uma escala de preferência. Segundo Passarelli, "essa escala de preferência varia em função do tipo de bem em questão. Ela move-se por meio dos principais setores da economia em que existe ocorrência significativa de bens ou serviços de luxo" (2010, p. 42).

Cada grupo de consumidor terá seu comportamento baseado em diversas circunstâncias. Inúmeros conceitos podem mudar e cada vez mais rápido, com o lançamento de novas plataformas, mudanças sociais e culturais. 


\section{Comportamento do consumidor de luxo nas redes sociais}

Claro que na sociedade atual, com o compartilhamento de experiências, novos modos de consumo de informação e novos modelos de produção, grande parte da comunicação é estrategicamente dirigida para as mídias sociais.

Mas para definir e usar uma estratégia voltada às mídias sociais, precisamos conhecer e entender as características e o comportamento do target a ser alcançado e atendido. Quando escolhemos a perspectiva das redes sociais e lojas virtuais, temos que ver além do perfil do nosso consumidor, pois a forma de contato que temos com ele é diferente. Não estamos com o contato personalizado, como em uma loja física, ou na própria casa do cliente. Nesse sentido, a comunicação via redes sociais é massificada, mesmo que direcionada a uma pequena parte de consumidores.

Podemos começar pelo fato de que cada indivíduo elou grupo tem suas características próprias e vivências e isso se estende ao seu comportamento na rede social. Como dissertam Tomaél, Alcará e di Chiara, "[n]as redes sociais, cada indivíduo tem sua função e identidade cultural. Sua relação com outros indivíduos vai formando um todo coeso que representa a rede" (2005, p. 93).

Nas plataformas sociais, ainda contamos com o reflexo de inúmeras mudanças causadas pela transformação digital. Cada vez mais lidamos com tecnologias, aplicativos, plataformas, em uma reconfiguração geral do que conhecíamos anteriormente.

Ao longo de muitos anos, as transações comerciais eram basicamente unilaterais, em que o cliente apenas comprava e o vendedor apenas vendia. Hoje essa realidade mudou totalmente, o consumidor não aceita mais uma relação passiva na qual ele apenas acata o que lhe é dado, seja em questão de produto/serviço ou de campanhas e posicionamentos que a marca assume diante dos diversos assuntos importantes que possam entrar em questão a qualquer momento. No século $\mathrm{XXI}$, os consumidores fizeram com que suas opiniões e percepções se tornassem relevantes, fazendo com que as empresas moldassem a condução de seus negócios de acordo com o consumidor.

O consumidor interage de diversas formas com o produto e com a marca que pretende adquirir, seja com seus amigos, com outros usuários 
ou por meio de influenciadoras digitais (contratadas pela marca ou não), avalia outras opções, realmente utiliza as redes sociais como objeto de avaliação e de tomada de decisão. Os consumidores se apresentam cada vez mais conectados e atentos, as mídias se tornaram uma maneira de manter a conversa aberta com o público, isto é, o comportamento do consumidor nas redes sociais está fortemente ligado à interatividade e ao engajamento, entre si e com as marcas que considera relevantes.

\section{O mercado de luxo na atualidade}

Um setor mais do que centenário e que, ainda hoje, representa um importante mercado em termos globais, com números expressivos e modelos de negócio que inspiram muitas indústrias (sobretudo quando mencionamos a gestão de marcas), o setor de luxo está acostumado a ditar tendências, a manter um padrão de estilo entre seus consumidores. Porém, nas últimas décadas, as marcas têm visto a necessidade de "acompanhar a moda" e obter maiores retornos em suas receitas. Na companhia disso vieram todas as mudanças da sociedade e de suas tecnologias, formações e profissões, formando uma nova classe de endinheirados.

Mesmo com certos impasses, a categoria continua em sucessivo crescimento, como mostra pesquisa realizada pela empresa de consultoria Deloitte em 2018: apenas as 100 maiores companhias venderam 2,47 bilhões de dólares, com taxa de crescimento de 5,3\% entre 2015 e 2017 e estimativa de crescer ainda mais nos próximos anos (em torno de $3 \%$ a $5 \%$ até 2025). Destacam-se países emergentes como Brasil e China, que são os que detêm a maior parte dos considerados "novos ricos" uma novidade para o setor, que lida com um novo tipo de consumidor não tão apegado às tradições, mas atraído por inovação e luxo (OS PODEROSOS [...], 2019).

Além dos novos ricos, contamos com as novas gerações que cresceram e agora possuem poder de compra. Essas procuram um relacionamento individualizado com a marca, sem costura. Para isso, as marcas de luxo têm investido no digital: mídias sociais e sites/e-commerces e marketplaces. O foco do negócio passou a ser o consumidor e sua 
demanda, o que fortalece a adoção da abordagem digital, ou seja, a abordagem por mais de um canal, mantendo a comunicação e conexão mais próxima, mesmo quando o cliente não está na loja. Com isso, o investimento no estudo do cliente com ajuda do Big Data e da inteligência artificial é usado no redesenho entre o velho e novo, na tentativa de conseguir oferecer serviços e produtos personalizados à sua base de clientes.

\section{Redes sociais e a importância da influência}

As redes sociais se encontram dentro do que chamamos de mídias sociais, que de acordo com Kim e Ko (2012), são mídias, aplicativos e plataformas que irão facilitar a interação e a colaboração do compartilhamento de conteúdo e estão apresentadas de diversas maneiras e formatos, como redes sociais, blogs, podcasts, micro blogs, wikis, fotos e vídeos. Em outras palavras, "as redes sociais constituem uma das estratégias subjacentes utilizadas pela sociedade para o compartilhamento da informação e do conhecimento, mediante as relações entre atores que as integram" (TOMAÉL, 2005, p. 93).

No século XXI, estamos passando por uma nova revolução em que as redes sociais se tornaram grandes precursoras e parte decisiva de nossas vidas dentro dessa transformação. Hoje temos tudo ao alcance de um clique, seja no celular, tablet ou computador. Assim, também afirma Erik Qualman,

A notícia nos encontra. Tudo isso pode ser acessado facilmente do conforto do lar ou em trânsito, por meio de aparelhos móveis. [...] Como consequência da facilidade e velocidade com a qual a informação pode ser distribuída no universo social, os vencedores hoje são cada vez mais produtos e serviços aprovados nesse ambiente social, o que no fim das contas significa que quem ganha são as pessoas. (QUALMAN, 2011, p. 17)

As marcas e instituições têm se adaptado às novas e diferentes direções pelas quais os consumidores têm se dirigido, utilizando toda 
essa aproximação como uma ferramenta de marketing poderosíssima a favor de seus produtos e principalmente da marca. O foco é entender e se relacionar com o consumidor, seja por meio de dados recolhidos, comentários em posts ou interação em pesquisas de satisfação, e comunicar por meio de posts, usando mídia proprietária (ou seja, fazendo seu próprio conteúdo), seus valores e posicionamentos, gerando engajamento e fidelização para a marca, além da diminuição de custos com a proliferação de campanhas publicitárias.

Por meio da incorporação de ferramentas inovadoras e disruptivas, que permitiam, por exemplo, aos próprios consumidores criarem e compartilharem conteúdos fotográficos, de áudio e vídeo, as marcas então passaram a divulgar campanhas, mensagens, produtos, serviços e promoções interagindo diretamente com os consumidores, respondendo suas dúvidas, recebendo suas reclamações e, em última análise, fazendo-se presentes. Dessa forma, as marcas passaram a fazer das mídias sociais agentes ativadores para propagação de conteúdo. (PEREIRA; SCHNEIDER, 2017, p. 99)

Relatórios divulgados em 2018 pelas companhias We Are Social e Hootsuite (CIRIACO, 2018) mostram que, atualmente, cerca de 4 bilhões de pessoas têm acesso à internet e que 3,2 bilhões usam redes sociais, distribuídos em plataformas como Facebook, YouTube, Instagram e Twitter (as mais conhecidas e que trazem mais engajamento entre as existentes).

Estar atento à evolução das redes sociais é imprescindível. A cada dia, mais e mais funções vão aparecendo, as maneiras de distribuição de conteúdo pelos donos das plataformas de conteúdo também mudam, bem como o jeito que o consumidor quer receber e conhecer sobre a marca e o produto. Portanto, cabe usar a autonomia do público a seu favor, conhecendo seu comportamento e seu perfil, tornar-se parte do dia a dia dele, usando as redes sociais como base para uma relação duradoura com o cliente.

Prestar atenção sempre em como as plataformas e o consumidor se movimentam nos remete à importância e à influência existentes dentro das redes sociais advindas das conhecidas influenciadoras digitais. Mas, por definição, o que seriam as digital influencers? Gomes e Gomes 
(2017) classificam as influenciadoras digitais como indivíduos que engajam e envolvem um público, impactando no consumo e comportamento deles. Indo na mesma direção, Eloísa Felix cita:

o termo 'Digital Influencer' ou influenciador digital refere-se a uma pessoa que tem uma grande quantidade de seguidores nas redes sociais e que possui muita capacidade de influenciar os mesmos, tornando-se, desse modo, referência na indicação de produtos ou serviços. (FELIX, 2017, p. 24)

Em outras palavras, influenciadoras digitais são pessoas que conseguem interagir e estimular um grupo de pessoas a seguir determinados hábitos, influindo até mesmo em seu comportamento e decisão de compra. Hoje, a dinâmica de parceria com as influencers é bem diferente, pois a transformação do hobby em profissão e a evolução da publicidade, além de questões legais e de regulação, mudaram todo o cenário. Mas a maior mudança foi para as empresas, que antes se negavam a contratar uma "desconhecida" para falar de seus produtos e hoje se veem rendidas às "famosas da internet".

A opinião do influente é levada em conta por aqueles que o seguem, quando estes fazem suas escolhas mediante recomendações partidas do mesmo. No mais, indivíduos adotam certos comportamentos dos influentes, ainda que não haja recomendações por parte desses últimos, o que representa uma forma de influência por contágio. (ZANETTE, 2015 apud GOMES; GOMES, 2017, p. 20)

O engajamento e o conteúdo que o influente oferece convenceu as marcas a se aliarem a eles:

O modelo de negócios baseado na influência tem se mostrado lucrativo tanto para as marcas quanto para os influenciadores. A efetividade das estratégias de comunicação com influenciadores digitais tem se revelado através do aumento da visibilidade e das taxas de conversão de vendas, quando comparado à publicidade tradicional. (GOMES; GOMES, 2017, p. 8) 
Pacete (2018), do site especializado em publicidade Meio e Mensagem, cita pesquisa realizada pelo Instituto QualiBest que destaca a opinião de influenciadores como a segunda mais importante (49\%) na hora de decisão de compras, perdendo apenas para a opinião de parentes (57\%). Os antigos meios de comunicação publicitária também perdem nessa pesquisa, já que 39\% dos entrevistados preferem sites de reviews e blog contra apenas $17 \%$ que escolheram a TV e rádio.

O ponto em questão é justamente como as empresas devem trabalhar com os influenciadores. Isso deve ser realizado de maneira estratégica, muito bem planejada, desde a escolha da persona até qual maneira será a comunicação - via publipost, experiência, participação em ações. São inúmeras as oportunidades para utilizar os influenciadores para comunicar com seu consumidor ou simplesmente impulsionar produtos ou a marca.

\section{Mercado de luxo e as redes sociais}

O envolvimento nas redes sociais é uma realidade em todas as indústrias. Isso não ficou diferente para a indústria do luxo, afinal de contas, o "fenômeno" redes sociais atingiu toda a sociedade, já que o acesso às plataformas sociais é intenso nas diversas camadas sociais.

Logo, o interesse das marcas de luxo de estarem presentes na internet se tornou necessário, o que para os estudos e estratégias mercadológicas se apresenta um pouco antagônico como Martins e Ikeda (2016) expõem:

[...] a internet apresenta contradições aos princípios básicos do luxo: a falta de relacionamento humano e pessoal, que é uma importante ferramenta de vendas, e a exclusão do cheiro, paladar e toque, o que faz com que muito da experiência de compra seja perdida. (MARTINS; IKEDA; CRESCITELLI, 2016, p. 212)

Atender a essa necessidade estratégica, por outro lado, é vital para a marca. Kim e Ko (2012) reconhecem que as mídias sociais têm grande impacto na reputação da marca, principalmente para as que utilizam as redes sociais. 
A melhor maneira de desenvolver essa estratégia e se proteger seria ingressar nas redes sociais, mensurando e recolhendo dados a fim de entender o meio e poder tomar decisões acerca de como atuar. Uma das estratégias usadas é fazer lives de desfiles, quebrando o paradigma de que apenas convidados podem assistir aos desfiles ou de ter que esperar semanas até que saiam em revistas especializadas. Agora, o evento está na palma da sua mão, expandindo o alcance on-line por meio da escolha de personalidades famosas, como atrizes, atores, cantores e influenciadoras digitais.

\section{Resultado das entrevistas}

foram realizadas ao todo quatro entrevistas, em questionário por meio eletrônico, com profissionais da área de marketing e empresários do setor de luxo. Cada participante é de uma área diferente relacionada ao tema, e o objetivo é obter uma visão ampla do momento do mercado, com abertura para comparar ao conteúdo do referencial teórico e de pesquisas de mercado pré-existentes.

O respondente era convidado a responder oito questões, abrangendo os itens gestão de marcas, redes sociais, influenciadoras digitais e consumidores de luxo.

Sobre a relevância das redes sociais para o negócio de luxo e qual o ponto decisivo de entrada nas plataformas, foi unânime a conclusão de que, na atualidade, é extremamente importante a atuação das marcas de luxo nas redes sociais. O resultado concorda veementemente com o pesquisado em teorias:

É evidente que na sociedade atual, mediada por um constante compartilhamento de experiências e novos modos de produção e consumo de informações, grande parte dessas estratégias de comunicação seja direcionada para as mídias sociais. (PEREIRA; SCHNEIDER, 2017, p. 96)

Ainda encontramos coerência sobre o que é importante para esse gerenciamento, já que a teoria nos apresenta que devemos acompanhar 
a tendência de nossos consumidores e entender suas necessidades. $O$ relato dos convidados vai ao encontro da bibliografia, considerando importante acompanhar e integrar informações e dados, formando oportunidades de estar à frente das vontades de nossos consumidores, aproveitando o banco de dados e as ferramentas para mensurar e definir os resultados que irão fortalecer a importância da presença digital e dar uma direção para as estratégias futuras. Um ponto levantado por um dos entrevistados e de importante visibilidade é o fator tempo e o cuidado necessário com esse aspecto. Tratando-se de redes sociais, o tempo é veloz e táticas devem ser feitas para escapar das armadilhas da instantaneidade.

Desse modo, percebemos que a teoria acompanha a prática do dia a dia do mercado, alinhadas nos quesitos gerais. O valor trazido pela vivência de mercado e seus detalhes ajustados às visões da teoria formam um grande complexo de material que pode ser facilmente transformado em estratégias e em táticas de mercado.

Além disso, a experiência de questionar profissionais experientes na área de gestão de marcas foi extremamente importante para a consolidação das informações teóricas e para confrontar o que foi estudado ao longo do ano.

\section{Considerações finais}

o desenvolvimento do presente estudo possibilitou uma análise de como o mercado de luxo tem se adaptado à realidade das redes sociais e de como fazer a gestão da marca a partir disso, garantindo a experiência e a exclusividade pertencentes à empresa.

Quando falamos em um segmento que tem um público-alvo com vasto poder aquisitivo e forte expectativa no retorno do consumo, as marcas respondem a isso com um espectro de exclusividade e experiência, além da qualidade superior em bens e serviços, e a gestão de marcas aparece como um ponto de diferenciação das marcas de luxo que o fazem com excelência. Mas, assim como a problemática do trabalho levanta, a posição clássica dessas marcas foi abalada pela necessidade de entrada e participação nas redes sociais. Por isso, entender e estudar 
seu consumidor se torna um ponto chave de melhoria da comunicação de marca e do diálogo direto.

Conhecido também pela inovação, o setor procurou adequar-se aos novos modos de seu público-alvo (que acompanham os de toda uma sociedade) com estudos de perfil de consumidor e de demanda, conhecendo as ferramentas e os atores que nelas existem - como as influenciadoras digitais e os formadores de opiniões -, ajustando as táticas de publicidade de acordo com a necessidade de seu público e respeitando os valores e a história da marca.

Em congruência com a teoria, foi citada pelos respondentes a necessidade da presença nas redes sociais como estratégia, mesmo que de forma cautelosa e bem estruturada, com principal ponto no acompanhamento do consumidor e no estudo do seu perfil. Isso garante que a marca mantenha-se atual sem deixar sua história e valores para trás, sustentando o crescimento e mantendo a exclusividade com foco em experiências, item importante para o segmento.

Pudemos perceber que por mais que a entrada nas redes sociais seja importante e inevitável para a manutenção da marca, a visibilidade e o contato com o target, a empresa precisa se preocupar com os sentidos das experiências. Por mais que ainda seja um desafio difícil de se solucionar no meio digital, é importante investir para ser um canal de contato direto, que agrega valor para o consumidor e auxilia no entendimento e antecipação de desejos e necessidades, atitude vital em qualquer indústria e indispensável para um bom rendimento econômico.

\section{Bibliografia}

AAKER, David. Marcas: Brand Equity: gerenciando o valor da marca. 14. ed. São Paulo: Elsevier, 1998.

AAKER, David. On Branding: 20 princípios que decidem o sucesso das marcas. Porto Alegre: Bookman, 2015.

ALBINO, Sirlei de Fátima; FAQUETI, Marouva Fallgatter. Projeto De

Pesquisa. 2014. Instituto Federal Catarinense, Camboriú, 2014. Disponível em: https://bit.ly/3c6J7i0. Acesso em: 14 ago. 2019. 
ALLÉRÈS, Danielle. Luxo...: Estratégias / Marketing. Rio de Janeiro: FGV, 2010. CIRIACO, Douglas. Mais de 4 bilhões de pessoas usam a internet ao redor do mundo. TecMundo, Curitiba, 30 jan. 2018. Disponível em: https://bit.ly/2FCUGkF. Acesso em: 16 set. 2020.

D’ANGElO, André Cauduro. Precisar, não precisa. São Paulo: Nacional, 2006.

FELIX, Eloisa Costa. O papel das influenciadoras digitais no processo de decisão de compra. 2017. Trabalho de Conclusão de Curso (bacharelado em Administração) - Universidade Federal do Rio Grande do Norte, Natal, 2017.

GIGLIO, Ernesto Michelangelo. O comportamento do consumidor. São Paulo: Cengage Learning, 2010.

GOMES, Erika Cirqueira; GOMES, Evandro Ferreira. O papel dos Influenciadores Digitais no relacionamento entre Marcas e Millennials na Era Pós-Digital. In: Congresso de Ciências da Comunicação na Região Nordeste, 19., 2017, Fortaleza. Anais [...]. São Paulo: Intercom, 2017. Disponível em: https://bit.ly/2EV3GkD. Acesso em: 28 ago. 2020.

KIM, Angella J.; KO, Eunju. Do social media marketing activities enhance customer equity? An empirical study of luxury fashion brand. Journal of Business Research, Oxford, v. 65, p. 1480-1486, 2012.

MARTINS, Camila Assis; IKEDA, Ana Akemi; CRESCITELLI, Edson. Marcas de luxo na web: interação com o consumidor no ambiente virtual. REGE Revista De Gestão, São Paulo, v. 23, n.3, p. 211-221, 2016.

MERLO, Edgard Monforte; CERIBELI, Harrison. Comportamento do consumidor. Rio de Janeiro: LTC, 2014.

OS PODEROSOS do varejo de luxo 2019. Deloitte Brasil, [s. I.]., 9 maio 2019. Disponível em: https://bit.ly/34L4OIX Acesso em: 28 ago. 2020.

PACETE, Luiz Gustavo. Influenciadores já são a segunda fonte para tomada de decisão. Meio\&Mensagem, São Paulo, 7 jun. 2018. Disponível em: https://bit.ly/3gLQ5cT. Acesso em: 22 maio 2019.

PASSARELLI, Silvio. O universo do luxo: marketing e estratégia para o mercado de bens e serviços de luxo. Barueri: Manole, 2010.

PEREIRA, Laura Pedri; SCHNEIDER, Thaissa. A influência da comunicação das marcas de moda de luxo nas redes sociais no valor percebido pelo consumidor. Dobras, Santa Catarina, v. 10, n.22, p. 94-113, 2017. 
SAKAMOTO, Cleusa Kazue; SILVEIRA, Isabel Orestes. Como fazer projetos de iniciação científica. São Paulo: Paulus, 2014.

SERRALVO, Francisco Antônio (org.). Gestão de marca no contexto brasileiro. São Paulo: Saraiva, 2008.

STREHLAU, Suzane. Marketing do Luxo. São Paulo: Cencage Learning, 2008.

TOMAÉL, Maria Inês; ALCARÁ, Adriana Rosecler; DI CHIARA, Ivone Guerreiro. Das redes sociais à inovação. Ciência da Informação [online], Brasília, v. 34, n. 2, p. 93-104, 2005. 


\title{
Aplicabilidade da Metodologia CAMEL para avaliar o risco de crédito de instituições financeiras de grande porte listadas na $\mathrm{B} 3$ (Brasil, Bolsa e Balcão): estudo de caso do Banco Itaú Unibanco
}

Beatriz Tavares Barca da Silva

José Odálio dos Santos

\begin{abstract}
Resumo
O objetivo da pesquisa foi avaliar a eficácia da classificação de risco proposta pela metodologia CAMEL, para mensurar o risco de crédito da principal instituição nacional de grande porte listada na B3 (Brasil, Bolsa e Balcão) no período de 2015 a 2019 trata-se do Itaú Unibanco. A revisão teórica abordará os principais riscos da indústria bancária e os índices contábeis-financeiros componentes da Metodologia CAMEL. Para justificar a relevância do tema, foi apresentado o panorama do setor bancário nacional e destacada a sua importância para o financiamento do nível de atividades de empresas e pessoas físicas. A análise quantitativa foi realizada com dados extraídos das demonstrações financeiras do Banco Itaú Unibanco. Os resultados extraídos e o rating obtido pela Metodologia CAMEL são compatíveis com situação contábil-financeira favorável do Banco Itaú Unibanco no período analisado.
\end{abstract}

Palavras-chave: Intermediação Financeira. Metodologia CAMEL. Desempenho Contábil-Financeiro. 


\section{Introdução}

O setor bancário e a oportunidade representada pela existência do crédito são cruciais para a atividade econômica - em especial para o financiamento das necessidades emergenciais de médio e longo prazo por empresas e pessoas físicas. Para desempenhar essa função, as instituições financeiras agem como agentes intermediadores, captando recursos de poupadores e, após análise detalhada do risco de crédito, emprestando-os para aqueles clientes que apresentem capacidade de amortizar o serviço da dívida no cenário projetado mais conservador possível.

Dada a característica de alavancagem elevada das empresas do setor bancário e sua importância para o financiamento da atividade econômica, é indispensável o monitoramento de desempenho contábil-financeiro.

Considerou-se oportuna a ocasião para abordar o tema por destacar-se a importância do setor bancário para promover o financiamento da atividade econômica, a representação do setor na formação do PIB, o desempenho contábil-financeiro histórico favorável das instituições financeiras de grande porte e o interesse contínuo do setor acadêmico constatado pelo desenvolvimento de pesquisas de temas diferenciados sobre a indústria bancária.

O objetivo desta pesquisa foi avaliar a eficácia da classificação de risco proposta pela Metodologia CAMEL para mensurar o nível de solvabilidade da principal instituição nacional de grande porte listada na B3 (Brasil, Bolsa e Balcão), no período de 2015 a 2019 - Banco Itaú Unibanco.

\section{Fundamentação teórica}

Nos itens seguintes, são destacadas algumas particularidades, características, riscos e a Metodologia CAMEL para avaliação do desempenho de instituições financeiras 


\section{Atividade bancária}

Os bancos atuam como intermediadores, captando recursos de agentes superavitários para, em seguida, repassá-los aos agentes deficitários após a realização de uma análise detalhada do risco de crédito.

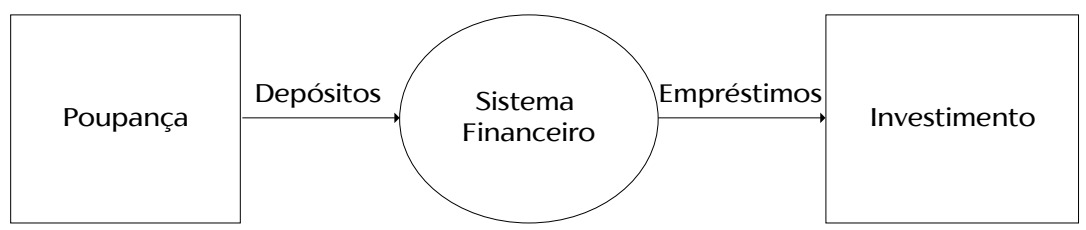

Figura 1. Esquema simples do funcionamento do sistema financeiro Fonte: BEBCZUK, 2003. Adaptado pelos autores

\section{Reserva de capital e Índice de Basiléia}

Historicamente, as entidades bancárias de grande porte têm reservas de capital mais do que suficientes para evitar a situação de insolvência técnica. Fato que atesta essa afirmação é a relação favorável entre o patrimônio de referência e o valor dos ativos ponderados pelo risco (risk weighted assests-RWA). Trata-se do Índice de Basiléia, também conhecido como índice de solvência ou de solvabilidade de uma instituição financeira. O Índice de Basiléia mínimo exigido pelo Banco Central do Brasil é de $11 \%$, mesmo que entidades bancárias nacionais de grande porte tenham apresentado, em média, taxas superiores.

A Figura 2 apresenta o Índice de Basiléia das maiores entidades bancárias nacionais de grande porte no período de 2017 a 2019. Especificamente para 2019, tem-se que para cada $\mathrm{R} \$ 100,00$ emprestados, existe um patrimônio de $\mathrm{R} \$ 17,10$ - muito acima do mínimo exigido, que é de $11 \%$ ou $R \$ 11,00$. 


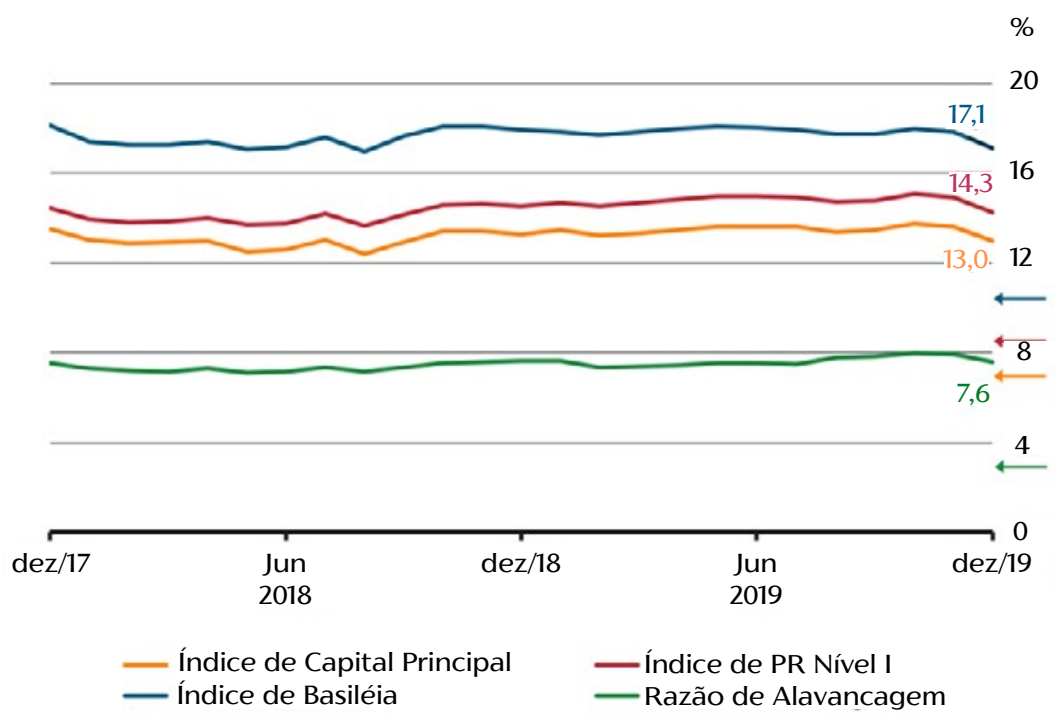

Figura 2. Índice de Basiléia no histórico dos maiores bancos do Brasil Fonte: BCB, 2020, p. 33.

\section{Riscos específicos da atividade bancária}

As atividades bancárias estão sujeitas a riscos que são inerentes ao seu negócio, tais como os riscos relacionados às transações de crédito, liquidez, volatilidade da taxa de juros, mercado, fator interno/operacional e paridade cambial.

\section{Risco de crédito}

Pereira (2016) define risco a crédito como a probabilidade de ocorrência de impactos negativos nos resultados ou no capital, devido à incapacidade de uma contraparte cumprir os seus compromissos financeiros perante a instituição, incluindo possíveis restrições à transferência de pagamentos do exterior. Para Pereira (2016), o risco de crédito existe principalmente nas linhas de crédito, garantias e derivados.

Segundo Santos (2015), ao conceder crédito, as empresas se expõem ao risco de inadimplência - ou seja, à probabilidade de não-recebimento (parcial ou total) do valor do financiamento. Para minimizar esse risco, 
os credores devem realizar uma análise minuciosa de todas as informações do cliente: cadastrais, financeiras, patrimoniais e de idoneidade.

Complementarmente, devem fazer provisões baseadas em parâmetros históricos e em expectativas do cenário econômico para cobrir perdas com tomadores inadimplentes.

Segundo Securato (2007) e Santos (2015), a avaliação do risco de crédito deve considerar informações relevantes do tomador, considerando dados cadastrais, setoriais, contábeis-financeiros e do cenário econômico.

Dentre as formas de análise, destaca-se a realizada diretamente por pessoas - como a de natureza subjetiva, que é baseada na experiência adquirida dos analistas de crédito, no conhecimento técnico, no bom-senso e na disponibilidade de informações (internas e externas) que lhes possibilitem diagnosticar se o cliente possui idoneidade e capacidade de gerar receita para honrar o pagamento das parcelas do financiamento. (SANTOS, 2015)

\section{Risco de liquidez}

Para Saunders (2000), o risco de liquidez é associado aos prazos de amortização de passivos e de recebimento de ativos. Em relação ao passivo, ocorre quando os depositantes tomam a iniciativa de converter seus direitos financeiros em dinheiro, imediatamente. Assim, a instituição financeira é obrigada a captar fundos adicionais ou liquidar ativos para cobrir retiradas. O risco de liquidez relacionado aos ativos ocorre em consequência de compromisso de empréstimos, no qual um tomador saca fundos concedidos no empréstimo e a instituição financeira precisa cobri-lo no balanço imediatamente - o que gera uma demanda de liquidez.

Para minimizar a exposição ao risco de liquidez, é indispensável que as entidades bancárias sempre mantenham saldos suficientes em caixa/tesouraria para atender o aumento inesperado de resgates de depósito e aplicações financeiras, que comumente ocorre em cenário de crise econômica.

\section{Risco de taxa de juros}

Este risco de taxa de juro está associado à volatilidade das taxas de juro ativas e passivas e à não coincidência de prazos de repricing 
dos ativos, sendo representado pela possibilidade de perda financeira em função de variações das taxas de juro - flutuação das taxas de juros sobre as aplicações e captações, no mercado financeiro, em função das políticas macroeconômicas e alterações do mercado.

Para eliminar esse risco, é indispensável que as entidades bancárias obtenham spreads favoráveis - ou seja, consigam obter nas transações operacionais, taxas de juros em empréstimos e financiamentos maiores que o custo de captação com os depositantes.

\section{Risco de mercado}

Trata-se do risco de ocorrência de prejuízos resultantes de variações nos preços de ativos no mercado financeiro, relacionando-se com perdas causadas pela oscilação de preços das commodities, das taxas de juros e do câmbio. Como exemplos desse risco, têm-se a compra, venda e fixação do preço de commodities, o fechamento de câmbio, o embarque de mercadorias, os contratos a termo, contratação de empréstimos etc.

O risco de mercado está presente constantemente no mundo dos investimentos. Porém, sua intensidade varia conforme o andamento dos cenários interno e externo. O atual cenário do Covid-19 e as medidas de enfrentamento adotadas pelas entidades governamentais para controlar as infecções e mortes caracterizam uma forma agressiva de risco de mercado, resultando em redução do nível da atividade econômica que prejudica a geração de fluxo de caixa de empresas e pessoas e, consequentemente, causa a inadimplência no setor bancário.

Para mitigar esse risco, é indispensável que as entidades bancárias mantenham reservas de capital compatíveis e/ou superiores ao recomendado pelo Comitê da Basiléia.

\section{Risco operacional}

É definido como a possibilidade de ocorrência de perdas resultantes de falha, deficiência ou inadequação de quaisquer processos internos envolvendo pessoas, sistemas, ou de eventos externos e inesperados.

Em geral, as perdas resultantes de riscos operacionais mal gerenciados ocorrem de três formas: 
- Falhas: comportamentos anormais, considerados defeitos de funcionamento - por exemplo: erro humano, defeitos em sistemas tecnológicos etc.

- Deficiências: ausência de estruturas (planos, departamentos, profissionais etc.) importantes para o processo organizacional - por exemplo: a falta de planos de contingência, a ausência departamentos de gerenciamento de riscos etc.

- Inadequações: procedimentos que fogem dos padrões estabelecidos - por exemplo: o descumprimento de dispositivos legais que, quando detectado, gera sanções etc.

\section{Risco cambial}

Consiste na incerteza frente ao valor da moeda como resultado das oscilações da taxa de câmbio. Logo, pode ser entendido como a probabilidade das taxas de câmbio entre as moedas dos países exportadores se moverem contrariamente entre a data de cotação e a de liquidação de um negócio; ou, também, a possibilidade de uma perda ou de um ganho resultante de uma variação nas taxas de câmbio entre moedas.

\section{Metodologia CAMEL}

A Metodologia CAMEL representa um sistema de classificação utilizado para auxiliar analistas na tarefa de medir a solidez e segurança de uma instituição financeira.

Essa metodologia foi criada originalmente pelo Banco Central Americano - ou Federal Reserve (FED) - para avaliar a solvabilidade de entidades bancárias através de um sistema de classificação de risco conhecido como rating.

Segundo Godoi et al. (2016) e Capelletto (2008), essa metodologia é uma das usadas pelos órgãos de supervisão bancária para avaliar o desempenho das entidades bancárias.

Dentre os índices ou indicadores componentes da sigla CAMEL, destacam-se os apresentados no Quadro 1 a seguir: 
Quadro 1. Índices ou indicadores da sigla CAMEL

\begin{tabular}{|c|c|}
\hline $\begin{array}{l}\text { Capital Adequacy } \\
\text { (Adequação do } \\
\text { capital) }\end{array}$ & $\begin{array}{l}\text { Refere-se ao capital necessário para garantir o equilíbrio } \\
\text { financeiro, tendo em vista o nível de risco assumido pela } \\
\text { instituição financeira. De acordo com Gomes, (2012), atender às } \\
\text { exigências de capital mínimo obrigatório é o fator chave para } \\
\text { a adequação de capital, mas manter um nível adequado de } \\
\text { capital é um elemento crítico. Dessa forma, o nível de capital } \\
\text { deve ser coerente com os riscos assumidos pela instituição, } \\
\text { além de ser possível monitorar e controlar esses riscos. } \\
\text { Este é representado internacionalmente pelo índice de } \\
\text { Basileia que, através do acordo de Basileia, estabeleceu os } \\
\text { limites mínimos de capital de 11\%, assegurando assim o normal } \\
\text { funcionamento das instituições financeiras. }\end{array}$ \\
\hline $\begin{array}{l}\text { Asset Quality } \\
\text { (Qualidade dos } \\
\text { ativos) }\end{array}$ & $\begin{array}{l}\text { É a supervisão dos riscos a créditos. Dentre as suas aplicações } \\
\text { estão as provisões para cobrir eventuais perdas em transações } \\
\text { ativas e passivas. Segundo Grier (2007), a fraca qualidade } \\
\text { dos ativos [non-performing loans] é a principal causa de } \\
\text { insolvência nas instituições financeiras. }\end{array}$ \\
\hline $\begin{array}{l}\text { Management } \\
\text { (Capacidade } \\
\text { gerencial) }\end{array}$ & $\begin{array}{l}\text { Para Gomes (2012), a qualidade da gestão refere-se à capacidade } \\
\text { do conselho de administração em identificar, medir e controlar } \\
\text { os riscos da atividade bancária e garantir uma operação } \\
\text { estável, sólida e eficiente dentro do cumprimento das leis e } \\
\text { regulamentos aplicáveis. Desse modo, está relacionado } \\
\text { a competência dos administradores na gestão do risco. } \\
\text { É usado para sua verificação o índice de eficiência operacional } \\
\text { que representa, por exemplo, a relação entre as despesas } \\
\text { operacionais e a receita de intermediação financeira }\end{array}$ \\
\hline $\begin{array}{l}\text { Earnings } \\
\text { (Resultados) }\end{array}$ & $\begin{array}{l}\text { Relaciona-se com índices de rentabilidade e ao longo do } \\
\text { período, como, por exemplo, o retorno sobre o investimento } \\
\text { e o retorno sobre o patrimônio líquido. }\end{array}$ \\
\hline $\begin{array}{l}\text { Liquidity } \\
\text { (Liquidez) }\end{array}$ & $\begin{array}{l}\text { De acordo com Gomes (2012), é fundamental que uma } \\
\text { instituição financeira tenha variadas fontes de liquidez, } \\
\text { incluindo disponibilidades imediatamente convertíveis em } \\
\text { dinheiro. As políticas de gestão de liquidez devem garantir } \\
\text { que uma instituição seja capaz de manter um nível de liquidez } \\
\text { suficiente para cumprir as suas obrigações financeiras e } \\
\text { ao mesmo tempo capazes de liquidar ativos rapidamente, } \\
\text { com perda mínima. Para Ross et al. (2015), este risco está } \\
\text { relacionado a capacidade da empresa pagar pontualmente } \\
\text { suas contas de curto prazo. }\end{array}$ \\
\hline
\end{tabular}

Fonte: Elaboração própria. 


\section{Matriz de pontuação final - CAMEL}

A Metodologia CAMEL apresenta uma pontuação e ponderação relativa para cada quesito destacado no Quadro 1. Essa pontuação varia de 1 a 5, em que 1 é a nota obtida para a melhor pontuação.

Segue exemplificação e interpretação de indicadores extraídos da Metodologia CAMEL:

- Adequação de capital: no contexto de adequação de capital, uma classificação 1 indica um nível de capital adequado em relação ao risco da instituição financeira. Por outro lado, uma classificação 5 indica um nível crítico de deficiência de capital, em que a assistência imediata dos acionistas ou recursos externos é necessária.

- Qualidade dos ativos: no contexto da qualidade dos ativos, uma classificação 1 indica uma qualidade de ativos excelente e risco da carteira de crédito mínimo. Por outro lado, uma classificação 5 reflete uma qualidade de ativos deficiente, que representa uma ameaça iminente para a solvabilidade da instituição.

- Qualidade da gestão: no contexto da qualidade da gestão, uma classificação 1 indica uma gestão exemplar. Por outro lado, uma classificação 5 reflete uma qualidade de gestão criticamente deficiente, que representa uma ameaça iminente para a solvabilidade da instituição.

- Resultados: no contexto dos resultados, uma classificação 1 reflete resultados que são suficientemente robustos para manter níveis de capital adequado e concessão de crédito. Por outro lado, uma classificação 5 exprime perdas constantes e representa uma ameaça à solvência da instituição financeira através da deterioração do capital.

- Liquidez: no contexto de liquidez, uma classificação 1 representa níveis de liquidez robustos e uma estrutura de financiamento estável capaz de atender às necessidades de liquidez correntes e previstas. Por outro lado, uma classificação 5 significa uma situação crítica de liquidez e a instituição exige assistência externa imediata para atender necessidades de liquidez.

Para que a Metodologia CAMEL seja implementada, é necessária a adoção dos procedimentos seguintes: 
I. Escolha dos indicadores contábeis-financeiros e respectiva ponderação de pesos relativos para a classificação de risco;

II. Escolha dos atributos ou critérios de classificação de risco, como péssimo, ruim, bom ou ótimo.

A matriz de pontuação tem por objetivo facilitar o processo de tomada de decisão dos gestores em condições internas (avaliação de desempenho) e externa (concessão de crédito, investimentos, entre outras).

Conforme Duarte Júnior (2005), o objetivo da Metodologia CAMEL é gerar uma amostra final de notas capaz de mensurar os riscos de cada companhia, sendo que essa amostra de notas será utilizada por analistas e investidores auxiliando-os na gestão de carteiras de ativos e no deferimento de crédito.

\section{Índices CAMEL utilizados para avaliação de solvabilidade}

O Quadro 2 apresenta exemplos de índices da Metodologia CAMEL, utilizados para avaliar o grau de solvabilidade de entidades bancárias.

Quadro 2. Índices da Metodologia CAMEL selecionados para a pesquisa

\begin{tabular}{|l|}
\hline \multicolumn{1}{|c|}{ CAPITAL } \\
\hline Índice Basiléia \\
\hline Endividamento Total \\
\hline PCLD / Carteira de Crédito \\
\hline Evolução da Carteira de Crédito \\
\hline Despesas Administrativas / Receita Total \\
\hline Despesas com Pessoal / Despesas Administrativas \\
\hline Despesas Intermediárias / Receitas Intermediárias \\
\hline \multicolumn{1}{c|}{ EARNINGS } \\
\hline Receitas com Crédito / Receita Total \\
\hline Margem Operacional \\
\hline RPL \\
\hline \\
\hline Liquidez Corrente \\
\hline Liquidez Imediata - Depósitos à Vista \\
\hline Liquidez Geral \\
\hline
\end{tabular}

Fonte: Elaboração própria. 
Capital

Índice de Basiléia (IB)

O IB é um indicador que mede o grau de alavancagem financeiro de uma instituição financeira, particularmente bancos. Todo banco deve manter um índice acima do exigido pelo Banco Central. É conhecido também como índice de solvência ou de solvabilidade de uma instituição financeira.

O IB é a relação entre o Patrimônio de Referência (PR) de uma instituição financeira e o valor dos Ativos Ponderados pelo Risco (RWA).

\section{Fórmula:}

$\mathbf{I B}=\underline{P R}$

RWA

O IB mínimo exigido pelo Banco Central do Brasil é de 11\%. Quanto maior esse referencial, melhor é a situação de solvência e solvabilidade do banco analisado.

\section{Endividamento Total (ET)}

Trata-se da relação entre o Passivo Total e o Ativo Total. No caso específico de instituições financeiras de grande porte, a elevada relação de dívidas frente ao Ativo Total não é necessariamente desfavorável tendo em vista a tarefa de intermediação financeira - que tem como foco repassar os recursos captados dos depositantes para agentes deficitários (pessoas físicas e empresas) via concessão de empréstimos que geram taxas de retornos mais do que suficientes para cobrir o custo de captação.

\section{Fórmula:}

ET $=$ Passivo Total

Ativo Total

\section{Assets}

Provisão de Crédito de Liquidação Duvidosa/Carteira de Crédito Compreende a relação entre a Provisão de Crédito de Liquidação Duvidosa (PCLD) e o valor total da Carteira de Crédito (CC). 
Intuitivamente, quanto maior a PCLD, maior é a exposição ao risco de crédito - ou seja, ao aumento das perdas financeiras em concessões de crédito na carteira (C).

\section{Fórmula: \\ $C=\underline{\text { PCLD }}$ \\ $\mathrm{CC}$}

Evolução da Carteira de Crédito (ECC)

Considera-se o desempenho do montante das operações de crédito em relação aos períodos anteriores.

\section{Fórmula:}

ECC $=$ Montante das operações de crédito no período atual $(t)$

Montante das operações de crédito no período anterior ( $t-1)$

Este indicador é sempre favorável quando o crescimento das concessões de crédito não está atrelado ao aumento de provisões de crédito de liquidação duvidosa.

\section{Management}

\section{Despesas Administrativas / Receita Total}

Relação entre o montante das Despesas Administrativas (DA) e a Receita de Intermediação Financeira (RIF).

Quanto menor as DA em relação à RIF, melhor é a situação contábil-financeira.

\section{Despesas com Pessoal / Despesas Administrativas}

Métrica que avalia a participação relativa das despesas com recursos humanos (Despesas com Pessoal) frente ao total contabilizado de despesas administrativas no período.

Quanto menor as DP em relação à DA, melhor é a situação contábil-financeira. 
Despesas com Intermediação (DI) / Receitas com Intermediação (RI)

Refere-se à relação entre os principais indicadores de receita e despesa da atividade bancária - intermediação financeira.

Quanto menor as DI em relação à RI, melhor é a situação contábil-financeira.

\section{Earnings}

Receitas com Crédito / Receita Total

Compreende a relação entre as Receitas com Concessão de Crédito (RC) frente à Receita Total obtida na atividade bancária.

Ao considerar que o principal fato gerador da receita de instituições bancárias é a concessão de crédito para pessoas físicas e jurídicas, assume-se que quanto maior for a RC, melhor é a situação contábil-financeira.

\section{Margem Operacional (MO)}

Representa a relação entre o Lucro Operacional (LO) e a Receita de Intermediação Financeira (RIF).

Quanto maior a MO, melhor é a situação contábil-financeira.

\section{Fórmula:}

MO $=\underline{L O}$

RIF

Retorno sobre o Patrimônio Líquido (RPL)

Representa a relação entre o Lucro Líquido (LL) e a Patrimônio Líquido (PL).

Quanto maior o RPL, maior o retorno destinado aos detentores do capital patrimonial e, consequentemente, melhor é a situação contábil-financeira.

\section{Fórmula:}

RPL $=\underline{L L}$

PL 


\section{Liquidity}

\section{Liquidez Corrente (LC)}

Relaciona-se à capacidade de pagamento no curto prazo, considerando a relação entre o valor total do Ativo Circulante (AC) frente ao valor total do Passivo Circulante (PC).

\section{Fórmula:}

\section{$\mathbf{L C}=\underline{\mathrm{AC}}$}

$\mathrm{PC}$

Índices de LC superiores a 1 e resultantes de ativos de liquidez imediata são favoráveis à gestão das instituições bancárias.

\section{Liquidez Imediata (LI)}

Relaciona-se à relação entre o valor total de Disponibilidades Financeiras (DF), ou Aplicações Financeiras, frente ao valor total de Depósitos à Vista (DV) - recursos captados de depositantes no mercado financeiro.

\section{Fórmula:}

$\mathbf{L I}=\underline{\mathrm{DF}}$

DV

Quanto maior a LI, melhor é a situação contábil-financeira.

\section{Liquidez Geral (LG)}

Relaciona-se à capacidade de pagamento no curto e no longo prazo, considerando a relação entre o valor total de Ativos de Curto e Longo Prazo (ACLP) frente ao valor total de Passivos de Curto e Longo Prazo (PCLP)

\section{Fórmula:}

$\mathbf{L G}=\underline{A C L P}$

PCLP 
Índices de LG superiores a 1 e resultantes de ativos com prazos de realização inferiores aos prazos de realização de passivos são favoráveis à gestão das instituições bancárias.

\section{Procedimentos metodológicos}

Para realizar a mensuração do nível de solvabilidade da entidade bancária selecionada como estudo deste caso (Banco Itaú Unibanco), foi necessário: a coleta e a operacionalização dos dados quantitativos na Planilha Excel, o cálculo dos índices, a classificação de risco pela Metodologia CAMEL, a análise individual dos índices contábeis-financeiros históricos de desempenho e, finalmente, a avaliação da medida de classificação de risco, ou rating de crédito.

\section{Resultados da pesquisa e análise}

A seguir serão apresentadas as análises dos índices da nomenclatura CAMEL para o Banco Itaú Unibanco.

Capital

Tabela 1. Índice Basiléia

\begin{tabular}{|l|c|c|c|c|c|}
\hline \multicolumn{1}{|c|}{ Capital } & 2015 & 2016 & 2017 & 2018 & 2019 \\
\hline Índice Basiléia & $17,78 \%$ & $19,07 \%$ & $18,80 \%$ & $17,97 \%$ & $15,80 \%$ \\
\hline
\end{tabular}

Fonte: Elaboração própria com base nos dados das demonstrações financeiras do Itaú Unibanco no período de 2015 a 2019

Apesar das oscilações, constata-se que seu IB é bem superior ao parâmetro estabelecido para o setor (11\%), evidenciando um nível de solvabilidade ou de reservas monetárias que dão sustentação a sua capacidade de honrar compromissos nos cenários mais conservadores 
projetados. Além disso, demonstra que o Itaú Unibanco possui recursos para cobrir perdas esperadas e inesperadas de caixa.

Tabela 2. Endividamento Total

\begin{tabular}{|c|c|c|c|c|c|}
\hline Capital & $\mathbf{2 0 1 5}$ & $\mathbf{2 0 1 6}$ & $\mathbf{2 0 1 7}$ & $\mathbf{2 0 1 8}$ & $\mathbf{2 0 1 9}$ \\
\hline Endividamento Total & $92,17 \%$ & $91,89 \%$ & $90,76 \%$ & $91,26 \%$ & $91,78 \%$ \\
\hline
\end{tabular}

Fonte: Elaboração própria com base nos dados das demonstrações financeiras do Itaú Unibanco no período de 2015 a 2019

O percentual médio do período de endividamento do banco Itaú foi de 91,57\%. Embora seja um dado elevado, é um valor comum no mercado bancário tendo em vista que uma de suas maiores atividades é a de intermediação financeira, em que há repasse aos agentes deficitários através da concessão de empréstimos. Nessa tarefa, são cobradas taxas de retorno (spreads) muito superiores ao custo de captação com os depositantes, resultando em elevadas margens de lucratividade histórica.

Assets

\section{PCDL / Carteira de Crédito}

Conforme mostra a Figura 3, a Provisão de Crédito para Devedores Duvidosos (PCDL) apresentou tendência de redução na predominância do período analisado, o que em parte é explicado pela adoção de procedimentos de análise de crédito mais seguros.

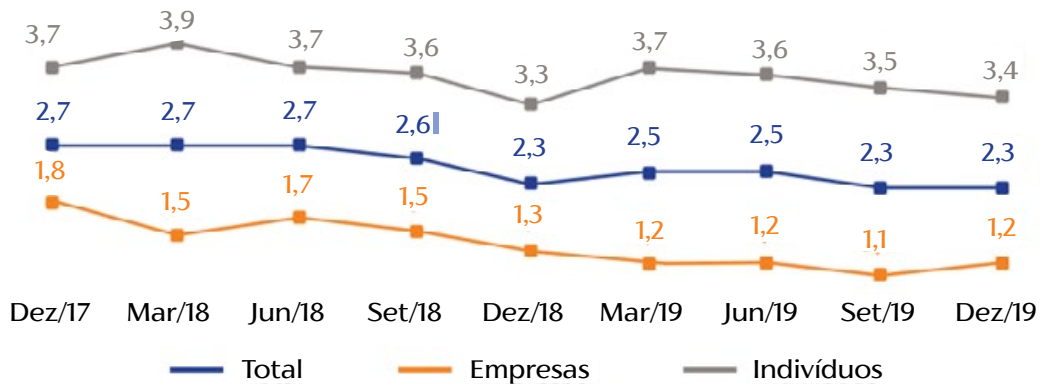

Figura 3. Índice de inadimplência de até 90 dias.

Fonte: ITAÚ UNIBANCO HOLDINGS S. A., 2020b, p. 80. 


\section{Evolução da Carteira de Crédito}

Em relação à evolução da carteira de crédito, há uma elevada oscilação em seu resultado no decorrer do período analisado - o que, em parte, é explicado pela existência de cenários econômicos diferentes no período. Intuitivamente, espera-se a maior concessão de empréstimos e financiamentos em cenários de estabilidade e crescimento do nível da atividade econômica. Em cenários econômicos adversos ocorre o contrário - ou seja, uma contração esperada do volume de concessão de empréstimos e financiamentos.

A Figura 4 apresenta o montante e o índice de perdas trimestrais na carteira de crédito (write-off) do Banco Itaú Unibanco entre os anos de 2017 e 2019. Apesar das oscilações, verifica-se uma variação relativa não significativa na carteira de crédito e nas perdas financeiras na predominância do período.

\section{Write-Off das Operações de Crédito}

$R \$$ milhões

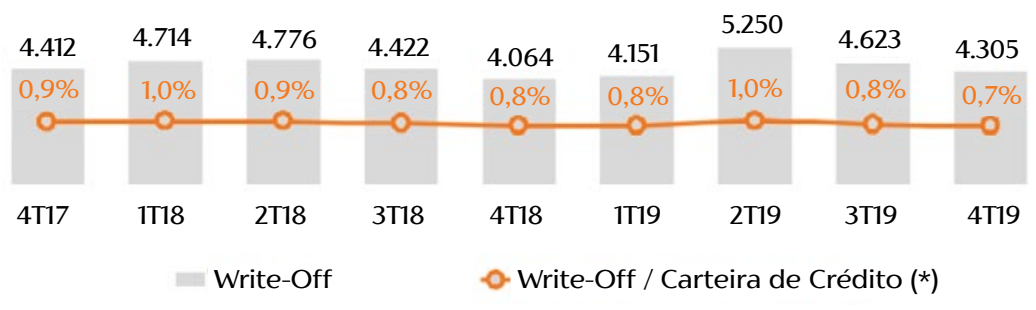

(*) Saldo médio da carteira de crédito considerando os dois últimos trimestres.

Figura 4. Redução da carteira de crédito do Banco Itaú Unibanco. Fonte: ITAÚ UNIBANCO HOLDINGS S.A., 2020a, p. 16.

\section{Management}

Tabela 3. Despesas Administrativas / Receitas Total

\begin{tabular}{|l|c|c|c|c|c|}
\hline \multicolumn{1}{|c|}{ Management } & 2015 & 2016 & 2017 & 2018 & 2019 \\
\hline $\begin{array}{l}\text { Despesas Administrativas / } \\
\text { Receita Total }\end{array}$ & $10,37 \%$ & $11,28 \%$ & $12,53 \%$ & $14,02 \%$ & $13,49 \%$ \\
\hline
\end{tabular}

Fonte: Elaboração própria com base nos dados das demonstrações financeiras do Itaú Unibanco no período de 2015 a 2019 
Ao observar esse índice no decorrer do período, verificamos que ocorreu uma oscilação predominantemente ascendente, em parte resultante do aumento de gastos indispensáveis nas áreas de recursos humanos e de estratégia empresarial, para dar sustentação ao crescimento de sua carteira de negócios.

Tabela 4. Despesas com Pessoal / Despesas Administrativas

\begin{tabular}{|l|c|c|c|c|c|}
\hline \multicolumn{1}{|c|}{ Management } & 2015 & 2016 & 2017 & 2018 & 2019 \\
\hline $\begin{array}{l}\text { Despesas com Pessoal } \\
\text { / Desp. Adm. }\end{array}$ & $52,44 \%$ & $54,24 \%$ & $54,74 \%$ & $54,67 \%$ & $57,55 \%$ \\
\hline
\end{tabular}

Fonte: Elaboração própria com base nos dados das demonstrações financeiras do Itaú Unibanco no período de 2015 a 2019

Como observamos no decorrer de 2015 a 2019, as despesas com recursos humanos tiveram um aumento ao longo do tempo de estudo. Segundo relatos extraídos das notas explicativas para 2019, essa elevação foi resultante de gastos com desligamentos, processos trabalhistas e investimentos em recursos digitais.

Tabela 5. Despesas Intermediação Financeira / Receitas Intermediação Financeira

\begin{tabular}{|l|c|c|c|c|c|}
\hline \multicolumn{1}{|c|}{ Management } & 2015 & 2016 & 2017 & 2018 & 2019 \\
\hline $\begin{array}{l}\text { Despesas Interm / } \\
\text { Receitas Interm }\end{array}$ & $69,59 \%$ & $53,60 \%$ & $55,98 \%$ & $58,98 \%$ & $54,30 \%$ \\
\hline
\end{tabular}

Fonte: Elaboração própria com base nos dados das demonstrações financeiras do Itaú Unibanco no período de 2015 a 2019

Constatou-se uma melhora desse indicador no período, principalmente quando se compara o período final (2019) com o período base (2015). A redução da participação percentual das despesas com intermediação financeira sobre as receitas de intemediação financeiras contribui para o aumento do lucro e, consequentemente, para a capacidade de honrar pagamentos de juros e do valor principal de dívidas contraídas. 


\section{Earnings}

Tabela 6. Receitas com Crédito / Receita Total

\begin{tabular}{|l|c|c|c|c|c|}
\hline \multicolumn{1}{|c|}{ Earnings } & 2015 & 2016 & 2017 & 2018 & 2019 \\
\hline $\begin{array}{l}\text { Receitas C/ Crédito / } \\
\text { Receita Total }\end{array}$ & $47,87 \%$ & $48,97 \%$ & $50,66 \%$ & $52,74 \%$ & $55,61 \%$ \\
\hline
\end{tabular}

Fonte: Elaboração própria com base nos dados das demonstrações financeiras do Itaú Unibanco no período de 2015 a 2019

Observa-se um aumento contínuo da participação das receitas com transações de crédito sobre a receita total. Esse desempenho é favorável e de grande interesse dos agentes de mercado, uma vez que as transações de crédito para empresas e pessoas físicas representam o principal fato gerador do lucro da indústria bancária.

Tabela 7. Margem Operacional

\begin{tabular}{|c|c|c|c|c|c|}
\hline Earnings & 2015 & 2016 & 2017 & 2018 & 2020 \\
\hline Margem Operacional & $9,01 \%$ & $22,37 \%$ & $22,31 \%$ & $22,28 \%$ & $19,92 \%$ \\
\hline
\end{tabular}

Fonte: Elaboração própria com base nos dados das demonstrações financeiras do Itaú Unibanco no período de 2015 a 2019

A margem operacional é uma das principais métricas utilizadas pelos agentes de mercado para avaliar o quanto a empresa é viável na condução da sua atividade operacional. Constata-se uma melhora significativa quando se compara o período final (2019) com o período base (2015).

Tabela 8. Retorno sobre o Patrimônio Líquido (RPL)

\begin{tabular}{|c|c|c|c|c|c|}
\hline Earnings & 2015 & 2016 & 2017 & 2018 & 2019 \\
\hline RPL & $21,94 \%$ & $18,72 \%$ & $17,25 \%$ & $17,33 \%$ & $18,61 \%$ \\
\hline
\end{tabular}

Fonte: Elaboração própria com base nos dados das demonstrações financeiras do Itaú Unibanco no período de 2015 a 2019

A despeito das oscilações no período, pode-se considerar o retorno ao detentor do capital patrimonial favorável. A média do período foi 
de $18,77 \%$, estando acima do rendimento de parte dos fundos de renda fixa. Além disso, a manutenção do resultado satisfatório no período foi resultante principalmente da geração de lucros após o imposto de renda predominantemente crescentes.

\section{Liquidity}

Tabela 9. Liquidez Corrente

\begin{tabular}{|c|c|c|c|c|c|}
\hline \multicolumn{1}{|c|}{ Liquidity } & 2015 & 2016 & 2017 & 2018 & 2019 \\
\hline Liquidez Corrente & 1,34 & 1,34 & 1,37 & 1,34 & 1,29 \\
\hline
\end{tabular}

Fonte: Elaboração própria com base nos dados das demonstrações financeiras do Itaú Unibanco no período de 2015 a 2019

Visualiza-se capacidade de pagamento no período mais do que suficiente para a cobertura das dívidas correntes - principalmente dos depositantes. A liquidez é considerada qualitativa, pois é resultante da realização da carteira de empréstimos, financiamentos e de aplicações financeiras de curto prazo.

Tabela 10. Liquidez Imediata / Depósitos à Vista

\begin{tabular}{|l|c|c|c|c|c|}
\hline \multicolumn{1}{|c|}{ Liquidity } & $\mathbf{2 0 1 5}$ & $\mathbf{2 0 1 6}$ & $\mathbf{2 0 1 7}$ & $\mathbf{2 0 1 8}$ & $\mathbf{2 0 1 9}$ \\
\hline $\begin{array}{l}\text { Liquidez Imediata - } \\
\text { Depósitos a Vista }\end{array}$ & 0,30 & 0,30 & 0,27 & 0,51 & 0,37 \\
\hline
\end{tabular}

Fonte: Elaboração própria com base nos dados das demonstrações financeiras do Itaú Unibanco no período de 2015 a 2019

Esse índice representa a capacidade de honrar saques de depósitos à vista utilizando recursos financeiros líquidos - ou seja, saldos em tesouraria e em aplicações financeiras de curto e curtíssimo prazo. O índice médio do período, de 0,35, atesta que o Banco Itaú Unibanco cobriria imediatamente $35,19 \%$ do montante de saques em depósitos à vista; trata-se de informação relevante, tendo em vista que o parâmetro de referência no mercado é de até $25 \%$. 
Tabela 11. Liquidez Geral

\begin{tabular}{|l|c|c|c|c|c|}
\hline \multicolumn{1}{|c|}{ LIQUIDITY } & 2015 & 2016 & 2017 & 2018 & 2019 \\
\hline Liquidez Geral & 1,07 & 1,09 & 1,08 & 1,07 & 1,07 \\
\hline
\end{tabular}

Fonte: Elaboração própria com base nos dados das demonstrações financeiras do Itaú Unibanco no período de 2015 a 2019

Tecnicamente, o Itaú Unibanco conseguiria cobrir o pagamento de suas dívidas de curto e longo prazo no período. Esse é um dos indicadores indispensáveis para analisar a capacidade de pagamento de uma instituição bancária.

\section{Análise ponderada dos índices da Metodologia CAMEL}

A Tabela 12 apresenta os critérios de avaliação pela Metodologia CAMEL considerando os índices de desempenho previamente apresentados e comentados do período de 2015 a 2019.

Tabela 12. Critérios de avaliação da metodologia CAMEL

\begin{tabular}{|c|c|c|}
\hline \multicolumn{3}{|c|}{ CRITÉRIOS } \\
\hline Escala & Avaliação & Rating \\
\hline$>0,5$ & Ótimo & A \\
\hline $0,45-0,49$ & Bom & B \\
\hline $0,40-0,44$ & Regular & $\mathrm{C}$ \\
\hline $0,35-0,39$ & Ruim & D \\
\hline$<0,35$ & Péssimo & E \\
\hline \multicolumn{3}{|c|}{ CRITÉRIOS } \\
\hline Escala & Avaliação & Rating \\
\hline$>0,5$ & Muito Forte & 1 \\
\hline $0,45-0,49$ & Forte & 2 \\
\hline $0,40-0,44$ & Satisfatório & 3 \\
\hline $0,35-0,39$ & Fraco & 4 \\
\hline$<0,35$ & Muito Fraco & 5 \\
\hline
\end{tabular}

Fonte: Elaboração própria 
A Tabela 13 apresenta a classificação de risco mensurada para o Banco Itaú Unibanco, considerando as notas/ponderações calculadas para cada fator componente da Metodologia CAMEL.

Tabela 13. Média dos resultados do período de 2015 a 2019.

\begin{tabular}{|c|c|}
\hline \multicolumn{2}{|c|}{ MÉDIA: PERÍODO DE 2015 A 2019} \\
\hline ÍNDICES / BANCOS & ITAÚ \\
\hline \multicolumn{2}{|l|}{ Capital } \\
\hline Índice Basiléia & $17,88 \%$ \\
\hline Endividamento Total & $91,57 \%$ \\
\hline \multicolumn{2}{|l|}{ Assets } \\
\hline PCDL / Carteira de Crédito & $95,74 \%$ \\
\hline Evolução da Carteira de Crédito & $21,29 \%$ \\
\hline \multicolumn{2}{|l|}{ Management } \\
\hline Despesas Administrativas / Receita Total & $87,66 \%$ \\
\hline Despesas com Pessoal / Desp. Adm. & $45,27 \%$ \\
\hline Despesas Interm / Receitas Interm & $41,51 \%$ \\
\hline \multicolumn{2}{|l|}{ Earnings } \\
\hline Receitas c/ Crédito / Receita Total & $51,17 \%$ \\
\hline Margem Operacional & $19,18 \%$ \\
\hline RPL & $18,77 \%$ \\
\hline \multicolumn{2}{|l|}{ Liquidity } \\
\hline Liquidez Corrente & $133,60 \%$ \\
\hline Liquidez Imediata -Depósitos a Vista & $35,19 \%$ \\
\hline Liquidez Geral & $107,57 \%$ \\
\hline Pontuação & 0,5250 \\
\hline Rating & A (Ótimo, muito forte) \\
\hline Rating & 1 (Ótimo, muito forte) \\
\hline
\end{tabular}

Fonte: Elaboração própria.

A classificação de risco obtida nesta pesquisa corrobora com a efetiva situação de solvabilidade histórica do Banco Itaú Unibanco. Sua pontuação média do período analisado foi de 0,5250, o que, segundo os critérios arbitrados, caracteriza-se como uma posição contábil-financeira favorável, mais do que suficiente para atender desembolsos esperados e inesperados de caixa - rating 1 (posição contábil-financeira forte). 
Avaliações técnicas de agências de ratings

Para validar e dar sustentação aos resultados apresentados, apresentamos a classificação de risco de crédito atribuída ao Banco Itaú Unibanco por uma das mais conceituadas agências de rating do mercado nacional e internacional, a MOODY's.

Especificamente no que concerne ao cenário nacional, parte das classificações corroboram os resultados desta pesquisa, destacando a solvabilidade e liquidez do Banco Itaú Unibanco através de ratings favoráveis identificados a partir da letra $\mathrm{B}$.

A MOODY's, por exemplo, ressaltou em seu parecer técnico que o Banco Itaú Unibanco está bem consolidado no que diz respeito à composição de indicadores centrais (liquidez, margem de intermediação financeira, rentabilidade, exposição segura a riscos sistêmicos e eficiência operacional).

\section{Cosiderações finais}

O risco a crédito ou de contraparte representa um dos maiores riscos no mercado bancário. Trata-se do risco de inadimplência dos tomadores de empréstimos e financiamentos - ou seja, do pagamento não pontual e/ou total da dívida contraída. Dependendo das perdas incorridas nas transações de crédito, o resultado poderá deteriorar a saúde financeira e a capacidade das instituições de honrar dívidas com os seus supridores de capital - particularmente com os depositantes.

Ao considerar esse cenário adverso, a presente pesquisa objetivou avaliar a classificação de risco de crédito de instituições bancárias através da Metodologia CAMEL. Como estudo de caso, foi selecionado o maior banco nacional privado de capital aberto - Banco Itaú Unibanco.

Os resultados obtidos não só corroboram, em parte, os achados de pareceres técnicos de agências tradicionais de classificação de risco, como também atestam a posição de segurança que o Banco Itaú Unibanco representa para os seus supridores de capital - principalmente os depositantes. No período analisado, seus índices médios caracterizaram uma situação favorável em termos de liquidez, alavancagem, 
margem de intermediação financeira e rentabilidade. A sustentação desta afirmação foi o rating obtido pela Metodologia CAMEL, denotando classificações de notoriedade ("muito forte", "ótimo", 1 e A) que caracterizam uma posição favorável de solvabilidade e liquidez.

A continuidade de pesquisas com este foco é de suma importância para a comunidade acadêmica e para o setor de instituições financeiras, tendo em vista as tarefas que exercem no financiamento das necessidades de curto e longo prazo de pessoas físicas e jurídicas.

\section{Referências}

BCB - BANCO CENTRAL DO BRASIL. Relatório de estabilidade financeira. Brasília, v. 19, n. 1, abr. 2020. Disponível em: https://bit.ly/3hFkD0s. Acesso em: 15 set. 2020.

BEBCZUK, Ricardo. Asymmetric information in financial markets: introduction and applications. Cambridge: Cambridge University Press, 2003.

CAPELLETTO, Lucio Rodrigues; CORRAR, Luiz João. Índices de riscos sistêmicos para o setor bancário. Revista Contabilidade e Finanças, São Paulo, v. 19, n. 47, p. 6-16, mar./ago. 2008.

DUARTE JÚNIOR, Antônio Marcos. Gestão de Riscos para Fundos de Investimentos. São Paulo: Prentice Hall, 2005.

GODOI, Alexandre Franco de; SANTOS, José Odálio dos; JACOB, Renato Manga; BERTONCELO, Valéria Regina. Análise das Variáveis Macroeconômicas e do acrônimo CAMELS sobre o retorno das ações ordinárias nas instituições financeiras nacionais de grande porte. Revista de Administração de Roraima, Boa Vista, v. 6, n. 1, p. 47-70, jan./jun. 2016.

GOMES, Ricardo Miguel Morais Pimentel. Análise de crédito a instituições financeiras: a metodologia CAMELS. 2012. Dissertação (Mestrado em Finanças) - Instituto Superior de Economia e Gestão, Universidade Técnica de Lisboa, Lisboa, 2012.

GRIER, Waymond A. Credit analysis of financial institutions. Londres: Euromoney Books, 2007. 
ITAÚ UNIBANCO HOLDINGS S. A. Análise gerencial da operação 4T19. São Paulo: 11 fev. 2020a. Disponível em: https://bit.ly/33yOUsr. Acesso em: 15 set. 2020.

ITAÚ UNIBANCO HOLDING S. A. Relatório anual integrado 2019. São Paulo: 15 jun. 2020b. Disponível em: https://bit.ly/3moldSB. Acesso em: 15 set. 2020.

ROSS, Stephen A.; WESTERFIELD, Randolpf. W.; JAFFE, Jeffrey; LAMB, Roberto. Administração financeira. 10. ed. Porto Alegre: AMGH, 2015. SANTOS, José Odálio dos. Análise de crédito: segmentos: empresas, pessoas físicas, varejo, agropecuária e pecuária. 6. ed. São Paulo: Atlas, 2015.

SAUNDERS, Anthony. Administração de instituições financeiras. São Paulo: Atlas, 2000.

SECURATO, José Roberto. Crédito: análise e avaliação do risco: pessoas físicas e jurídicas. São Paulo: Saint Paul, 2007.

SILVA, José Pereira da. Gestão e análise de risco de crédito. São Paulo: Cengage Learning, 2016. 


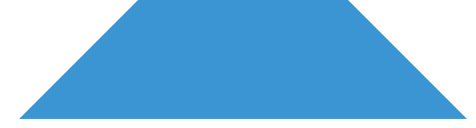

Esta coletânea traz as melhores produções acadêmicas dos discentes do curso de graduação de Administração da Pontifícia Universidade Católica de São Paulo (PUC-SP), contendo as pesquisas produzidas no período de 2018 a 2019, sejam do programa de Iniciação Científica, como trabalhos de conclusão de curso. Os artigos tratam dos assuntos mais importantes, urgentes e atuais referentes à área de administração. É a universidade fazendo seu papel de gerar conhecimento para o funcionamento da sociedade, ao mesmo tempo que incentiva o desenvolvimento de pesquisa por seus alunos.

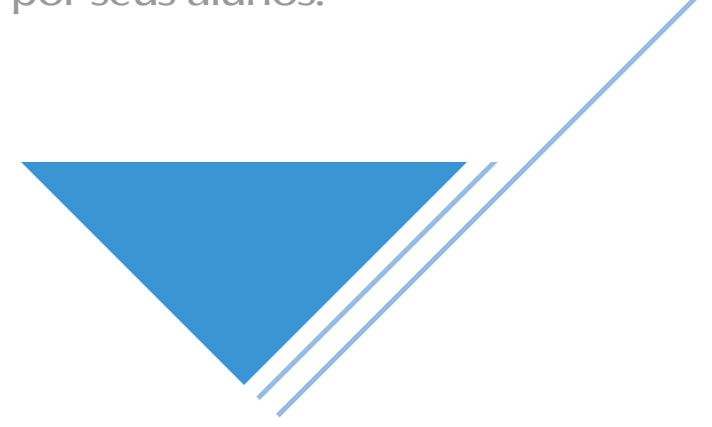

